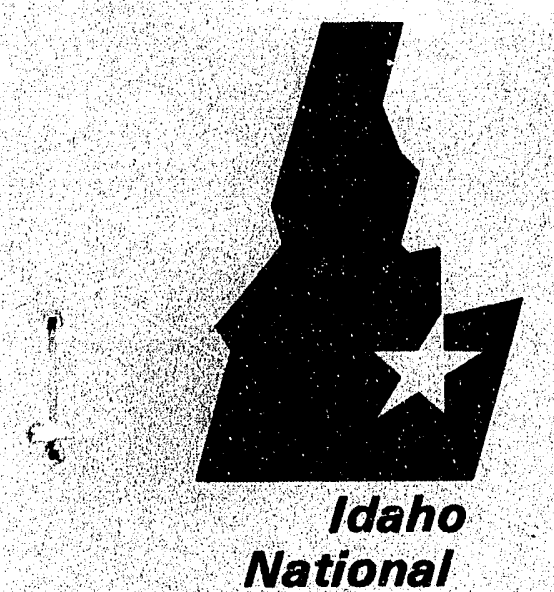

Engineering

Laboratory

Managed

by the U.S.

Department

of Energy
EGG-WM-10630

January 1993

\section{Processing Results of 1,800 Gallons of Mercury and Radioactively Contaminated Mixed Waste Rinse Solution}

B. P. Thiesen

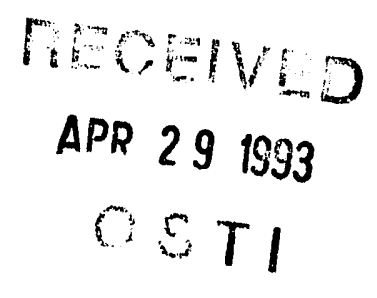

Work performed under No, DE-ACO7-761D01570 


\title{
Processing Results of 1,800 Gallons of Mercury and Radioactively Contaminated Mixed Waste Rinse Solution
}

\author{
B. P. Thiesen \\ Published January 1993 \\ Idaho National Engineering Laboratory \\ EG\&G Idaho, Inc. \\ Idaho Falls, Idaho 83415
}

Prepared for the U.S. Department of Energy Office of Environmental Restoration and Waste Management Under DOE Idaho Fleld Office Contract DE-AC07-76ID01570 


\section{ABSTRACT}

The mercury-contaminated rinse solution (INEL waste ID\# 123; File 8 waste) was successfully treated at the Idaho National Engineering Laboratory (INEL). This waste was generated during the decontamination of the Heat Transfer Reactor Experiment 3 (HTRE-3) reactor shield tank. Approximately 1,800 gal of waste was generated and was placed into 33 drums. Each drum contained precipitated sludge material ranging from 1-10 in. in depth, with the average depth of about 2.5 in. The $\mathrm{pH}$ of each drum varied from 3-11. The bulk liquid waste had a mercury level of $7.0 \mathrm{mg} / \mathrm{l}$, which exceeded the Resource Conservation and Recovery Act (RCRA) limit of $0.2 \mathrm{mg} /$. The average liquid bulk radioactivity was about $2.1 \mathrm{pCi} / \mathrm{ml}$, while the average sludge contamination was about $13,800 \mathrm{pCi} / \mathrm{g}$. Treatment of the waste required separation of the liquid from the sludge, filtration, $\mathrm{pH}$ adjustment, and ion exchange. The first process was the decanting and filtration of the liquid from the sludge. The sludge in the $\mathbf{3 3}$ drums was then combined into 4 drums and will be solidified. The $\mathrm{pH}$ of the liquid portion was adjusted and then processed by ion exchange in the Portable Water Treatment Unit (PWTU) located at the Test Area North (TAN) at the INEL. In order to remove the mercury, additional ion exchange columns containing $1.0 \mathrm{ft}^{3}$ of Purolite S-920 resin was installed into the PWTU system. Because of difficulties in processing, three trials were required to reduce the mercury levels to below the RCRA limit. In the first trial, insufficient filtration of the waste allowed solid particulate produced during $\mathrm{pH}$ adjustment to enter into the ion exchange columns and ultimately the waste storage tank. In the second trial, the waste was filtered down to $0.1 \mu$ to remove all solid mercury compounds. However, before filtration could take place, a solid mercury complex dissolved and mercury levels exceeded the RCRA limit after filtration. In the third trial, the waste was filtered through $0.3-\mu$ filters and then passed through the S-920 resin to remove the dissolved mercury. The resulting solution had mercury levels at $0.0186 \mathrm{mg} / \mathrm{l}$ and radioactivity of $0.282 \mathrm{pCi} / \mathrm{ml}$. This solution was disposed of at the TAN warm waste pond, TAN782, TSF-10. 


\section{CONTENTS}

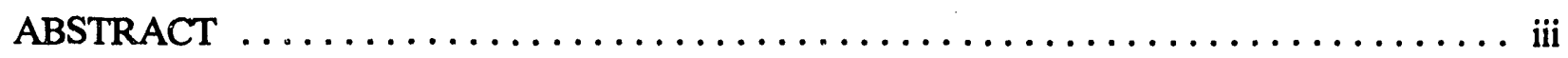

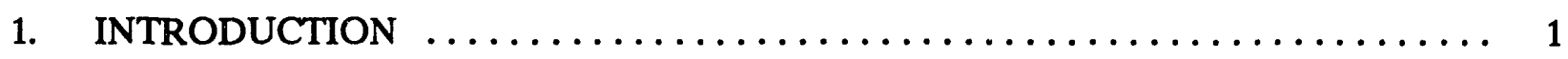

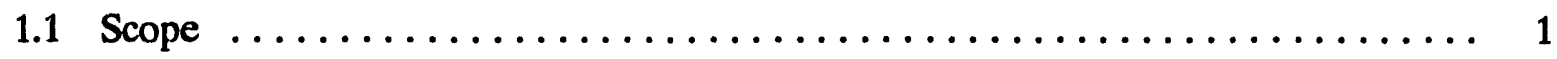

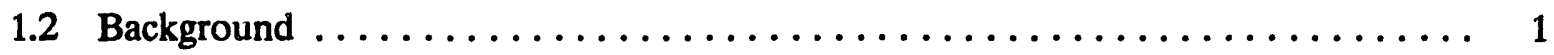

2. WASTE TREATMENT $\ldots \ldots \ldots \ldots \ldots \ldots \ldots \ldots \ldots \ldots \ldots \ldots \ldots \ldots \ldots \ldots \ldots$

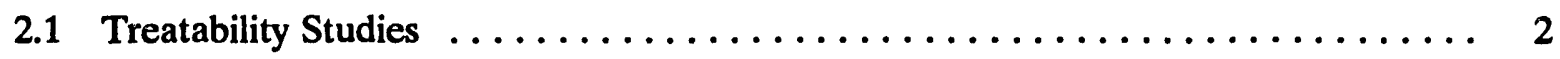

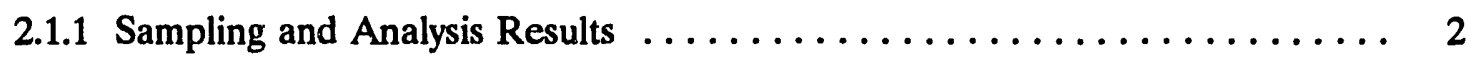

2.1.2 Treatability Results and Conclusions .................. 4

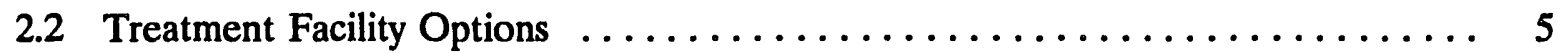

2.2.1 Portable Water Treatment Unit $\ldots \ldots \ldots \ldots \ldots \ldots \ldots \ldots \ldots \ldots \ldots$

2.2.2 Treatment Flow Diagram $\ldots \ldots \ldots \ldots \ldots \ldots \ldots \ldots \ldots \ldots \ldots \ldots$

2.3 Sludge Separation, $\mathrm{pH}$ Adjustment, and Ion Exchange, Trial $1 \ldots \ldots \ldots \ldots$

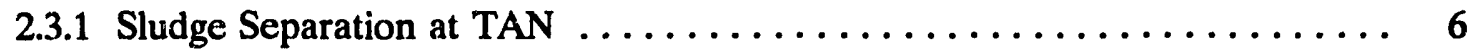

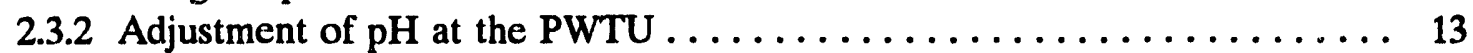

2.3.3 Filtering and Ion Exchange in the PWTU, Trial $1 \ldots \ldots \ldots \ldots \ldots \ldots$

2.3.4 Sampling and Analysis Results of pH Adjustment and Ion Exchange, Trial 1 . 15

2.4 Reprocessing by Filtration, Trial $2 \ldots \ldots \ldots \ldots \ldots \ldots \ldots \ldots \ldots \ldots \ldots \ldots$

2.4.1 Reprocessing by Filtration, Trial $2 \ldots \ldots \ldots \ldots \ldots \ldots \ldots \ldots \ldots \ldots$

2.4.2 Sampling and Analysis Results of Filtration, Trial $2 \ldots \ldots \ldots \ldots$

2.5 Reprocessing by Filtering and Ion Exchange, Trial $3 \ldots \ldots \ldots \ldots \ldots$

2.5.1 Reprocessing by Filtering and Ion Exchange, Trial $3 \ldots \ldots \ldots \ldots \ldots$

2.5.2 Sampling and Analysis Results of Filtering and Ion Exchange, Trial $3 \ldots \ldots 20$

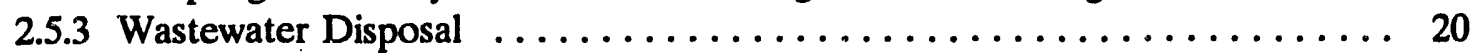

2.6 Sampling and Analysis of Filters and Resins $\ldots \ldots \ldots \ldots \ldots \ldots \ldots \ldots \ldots$

2.6.1 Sampling and Analysis Results of Filters ................ 20

2.6.2 Sampling and Analysis Results of Resins ................. 21

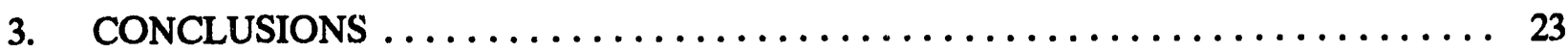


4. RECOMMENDATIONS .......................... 25

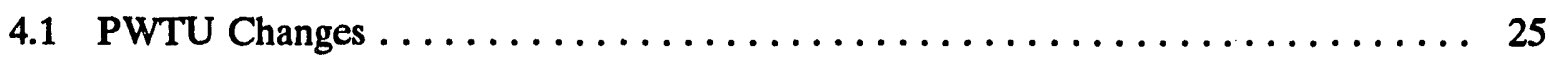

4.1.1 Permitting and Safety Documentation Changes $\ldots \ldots \ldots \ldots \ldots \ldots \ldots$

$4.1 .2 \mathrm{pH}$ Adjustment System Addition ...................... 25

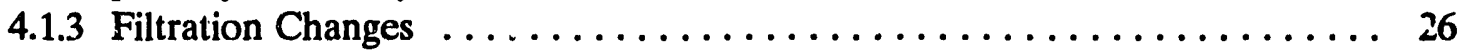

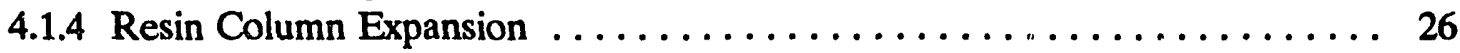

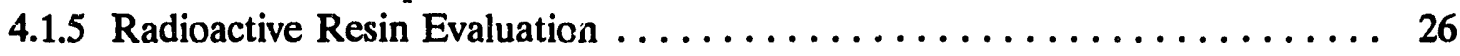

4.1.6 Final pH Adjustment Changes $\ldots \ldots \ldots \ldots \ldots \ldots \ldots \ldots \ldots \ldots \ldots \ldots$

4.2 PWTU Recommendation Summary $\ldots \ldots \ldots \ldots \ldots \ldots \ldots \ldots \ldots \ldots \ldots$

4.2.1 Permitting and Safety Documentation $\ldots \ldots \ldots \ldots \ldots \ldots \ldots \ldots \ldots \ldots$

4.2 .2 Larger Trailer . . . . . . . . . . . . . . . . . . . . 27

4.2.3 System Design Changes $\ldots \ldots \ldots \ldots \ldots \ldots \ldots \ldots \ldots \ldots \ldots \ldots \ldots \ldots \ldots$

Appendix A-PWTU Drawings $\ldots \ldots \ldots \ldots \ldots \ldots \ldots \ldots \ldots \ldots \ldots \ldots \ldots \ldots \ldots \ldots \ldots$

Appendix B-Filtering and Decanting Procedure $\ldots \ldots \ldots \ldots \ldots \ldots \ldots \ldots \ldots \ldots \ldots \ldots$

Appendix C-Resin and Resin Column Vendor Data $\ldots \ldots \ldots \ldots \ldots \ldots \ldots \ldots \ldots \ldots$ C-1

Appendix D-RML Radiochemistry Results $\ldots \ldots \ldots \ldots \ldots \ldots \ldots \ldots \ldots \ldots \ldots \ldots \ldots$

Appendix E-TCT TCLP Test Results $\ldots \ldots \ldots \ldots \ldots \ldots \ldots \ldots \ldots \ldots \ldots \ldots \ldots \ldots \ldots \ldots$ 


\section{Processing Results of 1,800 Gallons of Mercury and Radioactively Contaminated Mixed Waste Rinse Solution}

\section{INTRODUCTION}

\subsection{Scope}

This report addresses the processing of $1,800 \mathrm{gal}$ of mercury-contaminated mixed waste (also referred to as File 8 waste) at the Idaho National Engineering Laboratory (INEL). The objective is to detail the methods by which the waste (INEL waste ID\# 123) was processed and describe final waste forms and ultimate disposal of each waste form. Included in this report are details of processing problems and recommendations for future processing of similar wastes.

\subsection{Background}

The Test Area North (TAN) mercury-contaminated rinse solution was produced from the decontamination of the Heat Transfer Reactor Experiment 3 (HTRE-3) reactor shield tank. This reactor was designed as part of the airplane engine program. Shielding for the reactor was provided by an approximately 1,500-gal shield tank filled with mercury. This reactor since has been put on display at the Experimental Breeder Reactor I (EBR-I) museum.

Prior to the HTRE-3 reactor being sent to EBR-I for display, the residual mercury was removed by rinsing the shield tank with $30 \mathrm{wt} \%$ nitric acid solution. After rinsing the shield tank, the following processes were to be performed on the solution. The solution was to be transferred to a mixing tank, and the $\mathrm{pH}$ of the solution increased to about 10 by adding $50 \mathrm{wt} \%$ sodium hydroxide. Sodium sulfide was then to be added to convert the mercury to an insoluble mercury sulfide. Aluminum sulfate was then to be added to act as a flocculating agent. The solution was then to be neutralized to a $\mathrm{pH}$ of 7 and filtered through a $5-\mu$ filter.

Originally, it was anticipated that the resulting waste would pass Resource and Conservation Recovery Act (RCRA) limits and then disposed of as a nonhazardous, nonradioactive waste. However, the solution did not pass RCRA limits and the waste was placed into 33 polyethylene, 55-gal drums. The 33 drums of waste were then placed into the Mixed Waste Storage Facility (MWSF) at the INEL. Information from the waste characterization report and results from analyses performed on the waste indicate that the above procedures were not all performed, resulting in each waste drum having different metal concentrations and $\mathrm{pH}$. 


\section{WASTE TREATMENT}

The TAN mercury-contaminated rinse solution was treated as part of a treatability demonstration of mixed wastes at the INEL. Several similar mixed wastes have been identified at the INEL for potential treatment by ion exchange. The processing of the 1,800 gal of TAN mercury-contaminated rinse solution waste was to evaluate the treatability of this and similar wastes on a large scale by ion exchange and the requirements of a treatment system for future processing.

Prior to treatment of the 1,800 gal, treatability studies were performed on samples of the waste at the Test Reactor Area (TRA) radiochemistry lab located at the INEL. ${ }^{a}$ After completion of the treatability studies, treatment facility and treatment process options were evaluated and a processing scheme was developed. The following sections detail the processing of the 1,800 gal of mixed waste designated ID\# 123. Processing of this waste required three processing trials denoted as Trials 1,2 , and 3 .

\subsection{Treatability Studies}

Treatability studies were performed on samples of the waste to evaluate treatment options and recommend a treatment plan. The results of the treatability studies are detailed in footnote a. A summary of the treatability study is provided here.

\subsubsection{Sampling and Analysis Results}

In 1992, six of the 33 drums were sampled to perform treatability studies. The samples indicated that the waste had both a liquid phase and a solid sludge phase. It appeared from the sampled drums that sludge filled about 2-3 in. of the bottom of the drum. The sludge was a very fine particulate. The liquid was separated from the solids by using a $0.45-\mu$ filter, and both the liquid filtrate and the solids were analyzed for metals and radioactivity.

Some of the results of the analysis are shown in Tables $1-3$. Table 1 shows the concentrations of mercury and lead in the filtrate and the solid portion of the waste. A more complete metals analysis was obtained and is detailed in footnote a, but only mercury and lead were above the RCRA limits of $0.2 \mathrm{mg} / 1$ and $5.0 \mathrm{mg} / 1$, respectively. Table 2 shows the total activity of the filtrate and Table 3 shows the total activity of the solid portion of the waste.

The filtrate has a wide range of results for lead and mercury. Most of the mercury values are over the RCRA limit, ranging from 0.133 to $4.68 \mathrm{mg} / \mathrm{l}$ with an average of $1.156 \mathrm{mg} /$. Only one lead value is over the RCRA limit, ranging from 0.622 to $8.10 \mathrm{mg} / \mathrm{l}$ with an average of $3.03 \mathrm{mg} /$. The lead and mercury values for the sample from Drum 702 are not considered valid because the valves shown are outside the instrument detection limits and are not included in this discussion. The total activity of the filtrate is very low, ranging from 2.2 to $74 \mathrm{pCi} / \mathrm{ml}$ with an

a. D. R. Haefner, Treatability Study of Aqueous, Land Disposal Restricted Mixed Wastes, EGG-WM-10496, December 1992. 
Table 1. Mercury and lead concentrations of the liquid and solid portions of the sampled waste.

\begin{tabular}{ccccc}
\hline & \multicolumn{2}{c}{ Filtrate } & \multicolumn{2}{c}{ Solids } \\
\cline { 2 - 5 } Drum number & $\begin{array}{c}\text { Mercury } \\
\text { content } \\
(\mathrm{mg} / \mathrm{l})\end{array}$ & $\begin{array}{c}\text { Lead } \\
\text { content } \\
(\mathrm{mg} /)\end{array}$ & $\begin{array}{c}\text { Mercury } \\
\text { content } \\
(\mathrm{mg} /)\end{array}$ & $\begin{array}{c}\text { Lead } \\
\text { content } \\
(\mathrm{mg} / \mathrm{l})\end{array}$ \\
\hline 568 & $0.326 \pm 0.010$ & $0.622 \pm 0.019$ & $54.5 \pm 0.5$ & $101.3 \pm 0.8$ \\
572 & $0.133 \pm 0.005$ & $0.674 \pm 0.012$ & $2.98 \pm 0.03$ & $189.4 \pm 1.6$ \\
635 & $4.68 \pm 0.09$ & $2.88 \pm 0.04$ & $9.37 \pm 0.04$ & $651.4 \pm 1.8$ \\
697 & $0.340 \pm 0.012$ & $8.10 \pm 0.15$ & $138 \pm 10$ & $135.0 \pm 0.8$ \\
702 & $19,880 \pm 650$ & $1,120 \pm 20$ & $80 \pm 7$ & $66.9 \pm 1.0$ \\
703 & $0.301 \pm 0.010$ & $2.87 \pm 0.04$ & $46.9 \pm 0.3$ & $154.0 \pm 1.0$ \\
\hline
\end{tabular}

Table 2. Gross alpha and beta radioactive contamination of the liquid portion in the sampled waste.

\begin{tabular}{clcc} 
Drum number & $\begin{array}{c}\text { Dissolved solids } \\
(\mathrm{mg} / \mathrm{ml})\end{array}$ & $\begin{array}{c}\text { Filtrate gross } \alpha \\
(\mathrm{pCi} / \mathrm{ml})\end{array}$ & $\begin{array}{c}\text { Filtrate gross } B \\
(\mathrm{pCi} / \mathrm{ml})\end{array}$ \\
\hline 568 & 223.4 & $2.4 \pm 1.4 \mathrm{E}-1$ & $7.4 \pm 1.2 \mathrm{E}+1$ \\
572 & 16.6 & $2.8 \pm 1.0 \mathrm{E}-2$ & $6.5 \pm 1.1 \mathrm{E}-1$ \\
635 & 3.9 & $1.0 \pm 0.2 \mathrm{E}-1$ & $2.2 \pm 0.4 \mathrm{E}+0$ \\
697 & 264.4 & $0.6 \pm 1.6 \mathrm{E}-1$ & $3.7 \pm 0.7 \mathrm{E}+0$ \\
702 & 3.2 & $4.2 \pm 0.7 \mathrm{E}-1$ & $4.4 \pm 0.7 \mathrm{E}+1$ \\
703 & 89.6 & $2.3 \pm 0.7 \mathrm{E}-1$ & $2.7 \pm 0.5 \mathrm{E}+0$ \\
\hline
\end{tabular}


Table 3. Gross alpha and beta radioactive contamination of the filterable solid portion in the sampled waste.

\begin{tabular}{ccccc}
\hline Drum & $\begin{array}{c}\text { Filterable solids } \\
20.45 \mu \mathrm{m} \\
(\mathrm{mg} / \mathrm{ml})\end{array}$ & $\begin{array}{c}\text { Filterable } \\
\text { solids } \\
0.1-0.45 \mu \mathrm{m} \\
(\mathrm{mg} / \mathrm{ml})\end{array}$ & $\begin{array}{c}\text { Solids gross } \alpha \\
(\mathrm{pCi} / \mathrm{g})\end{array}$ & $\begin{array}{c}\text { Solids gross } B \\
(\mathrm{pCi} / \mathrm{g})\end{array}$ \\
\hline 568 & 935.6 & 9.7 & $3.6 \pm 0.9 \mathrm{E}+1$ & $2.0 \pm 0.3 \mathrm{E}+4$ \\
572 & 612.5 & 0.1 & $8 \pm 3 \mathrm{E}+1$ & $1.05 \pm 0.17 \mathrm{E}+3$ \\
635 & 782.1 & 0.0 & $-1.3 \pm 0.6 \mathrm{E}+1$ & $4.9 \pm 0.8 \mathrm{E}+3$ \\
697 & 277.3 & 2.6 & $-1.0 \pm 0.2 \mathrm{E}+3$ & $4.0 \pm 0.6 \mathrm{E}+4$ \\
702 & 4.0 & 0.2 & $3.6 \pm 0.9 \mathrm{E}+3$ & $1.0 \pm 0.3 \mathrm{E}+4$ \\
703 & 419.6 & 2.2 & $-2.9 \pm 0.8 \mathrm{E}+1$ & $7.1 \pm 1.1 \mathrm{E}+3$ \\
\hline
\end{tabular}

average of $21 \mathrm{pCi} / \mathrm{ml}$. The total activity of the sludge is much higher, ranging from 1,050 to $40,000 \mathrm{pCi} / \mathrm{g}$ with an average of $13,800 \mathrm{pCi} / \mathrm{g}$.

The original waste was thought to have been treated in a large mixing tank, then placed into the waste drums. However, the results from the six samples indicate that each waste container is different and has its own characteristics. All the samples have very high concentrations of sodium, reading beyond the capability of the analytical instrument, indicating that the sodium sulfide was probably added. Also, some of the samples have high concentrations of aluminum while others have almost no aluminum, indicating that some of the containers may of had aluminum sulfate added. The $\mathrm{pH}$ of the samples ranged from less than 3 to greater than 10 . It can be concluded that the waste probably had chemical additions after being placed into the drums.

\subsubsection{Treatability Results and Conclusions}

The treatment processes tested on a lab scale basis are detailed in footnote $b$. Ion exchange experiments were run in a glass column, $1.5 \mathrm{~cm}$ in dianeter and $20-25 \mathrm{~cm}$ tall. The following conclusions and recommendations for large scale processing of the waste were made:

- Results of the treatability study indicate that the waste can be treated to remove the hazardous heavy metals of mercury and lead by use of an ion selective resin. Two selective ion resins were recommended:

- GT-73 produced by Rhom and Hass.

- S-920 produced by Purolite.

b. D. R. Haefner, Treatability Study of Aqueous, Land Disposal Restricted Mixed Wastes, EGG-WM-10496, December 1992. 
The first resin, GT-73, proved to be slightly more effective with mercury and lead removal than the S-920.

- Heavy metal removal was most efficient at acidic conditions, pH 4-6, but also was effective under caustic conditions, $\mathrm{pH} \mathrm{8-10.} \mathrm{A} \mathrm{pH} \mathrm{drop} \mathrm{of} \mathrm{about} \mathrm{two} \mathrm{points} \mathrm{occurred}$ during processing of the waste.

- Heavy metal removal was effective at a flow rate of 10-12 bed volumes per hour.

- The GT-73 resin passed the RCRA toxicity characterization leaching procedure (TCLP) metals testing after treatment of the waste. The S-920 was not TCLP tested.

- The sludge failed for TCLP lead, but passed all other TCLP metals. This indicates that the filters will probably become a mixed waste.

The recommended procedure to process the waste is outlined below:

1. Neutralize the waste solution to a $\mathrm{pH}$ of $\mathbf{1 0 .}$

2. Filter the solution through a $0.45-\mu$ filter.

3. Process the solution through a resin column at a flow rate of 10-12 bed volumes per hour.

\subsection{Treatment Facility Options}

In order to treat the waste, a system capable of neutralization, filtration, and ion exchange had to be located. Also, because the waste is considered a mixed hazardous waste, the system to process the waste must be permitted to treat the waste's specific hazards under RCRA and State regulations. It was determined that the Portable Water Treatment Unit (PWTU) located at the INEL would be capable of processing the waste.

\subsubsection{Portable Water Treatment Unit}

The PWTU was originally designed to treat well water contaminated with low levels of radioactive isotopes and trichloroethylene at the INEL. The PWTU contains a filtering system, activated carbon beds, resin columns for radioactive isotope removal, and $\mathrm{pH}$ adjustment system as shown in the drawings in Appendix A.

All processing of the waste could not take place at the PWTU. The activity of the waste was too high to meet the requirements of the PWTU safety analysis report (SAR). However, the liquid portion could be processed at the PWTU if the liquid was separated from the sludge. It was determined by EG\&G Idaho, Inc., that the separation of the liquid from the solid and the repackaging of the liquid into separate waste drums was not hazardous waste treatment and could be performed at any facility with capabilities of handling the waste. The TAN Hot Shop was evaluated as being the best facility to separate the liquid from the solid portion of the waste. Factors included in the evaluation were the TAN Hot Shop SAR encompassed the waste's 
characteristics, the Hot Shop has trained personnel, and the PWTU is located about 500 yd from the TAN Hot Shop.

In order to use the PWTU, modifications to the system were required. The existing columns in the PWTU contained $\mathrm{C}-100 \mathrm{H}$ resin from Purolite. This resin is not capable of removing heavy metals to required concentrations below the RCRA limit. To remove the heavy metals from the waste, ion exchange columns packed with GT-73 and S-920 were installed. Also, a means to adjust the $\mathrm{pH}$ of the liquid prior to ion exchange had to be developed.

\subsubsection{Treatment Flow Diagram}

Figure 1 shows the flow diagram for the treatment of the waste. The waste was first removed from the MWSF and brought to the TAN Hot Shop, a trip of about $45 \mathrm{mi}$. The liquid waste was then separated from the sludge. The sludge was combined into four drums and sent back to the MWSF for future treatment. The liquid portion was pumped into clean 55-gal drums and taken to the PWTU storage area. At the PWTU the waste had the pH adjusted to 7-8. The waste was then processed in the PWTU and discharged to two polyethylene storage tanks. Upon verification of the treatment by sampling and analysis, the waste would be discharged to the warm waste pond at TAN.

\subsection{Sludge Separation, pH Adjustment, and Ion Exchange, Trial 1}

The processing of the waste entailed sludge separation at the TAN Hot Shop and pH adjustment and ion exchange at the PWTU. In this section the details of processing the waste are given.

\subsubsection{Sludge Separation at TAN}

Sludge separation at TAN entailed the transporting of the waste to the TAN Hot Shop area, separation of the liquid from the solid sludge portion, and repackaging of the sludge for storage at the MWSF. The details for each stage of the sludge separation process are detailed below.

2.3.1.1 Transportation of the Waste to the TAN Hot Shop Area. Because the Hot Shop is not a permitted treatment, storage, and disposal (TSD) facility, the waste could only be at the Hot Shop for 10 days. It was estimated that the sludge separation process could be completed in three days, but to ensure the time limit was not exceeded, two staggered shipments were made from the MWSF. The first shipment of 16 drums was brought September 2, 1992. The second shipment of 17 drums was brought September 3,1992. The drums were placed in a staging area at TAN.

2.3.1.2 Sludge Separation in the TAN Hot Shop. The liquid was separated from the sludge using the filter and pump assembly shown in Figure 2 and the procedures in Appendix B. The filtering system consisted of three series " $\mathrm{L}$ " Serfilco filter housings connected in series. Each filter housing accepts a 10-in., double-open-end filter. The first filter housing in the series had a $10-\mu$ absolute rated filter installed. The second filter housing had a $1-\mu$ absolute rated filter installed. The third filter housing had a $0.1-\mu$ absolute rated filter installed. Pressure indicators 


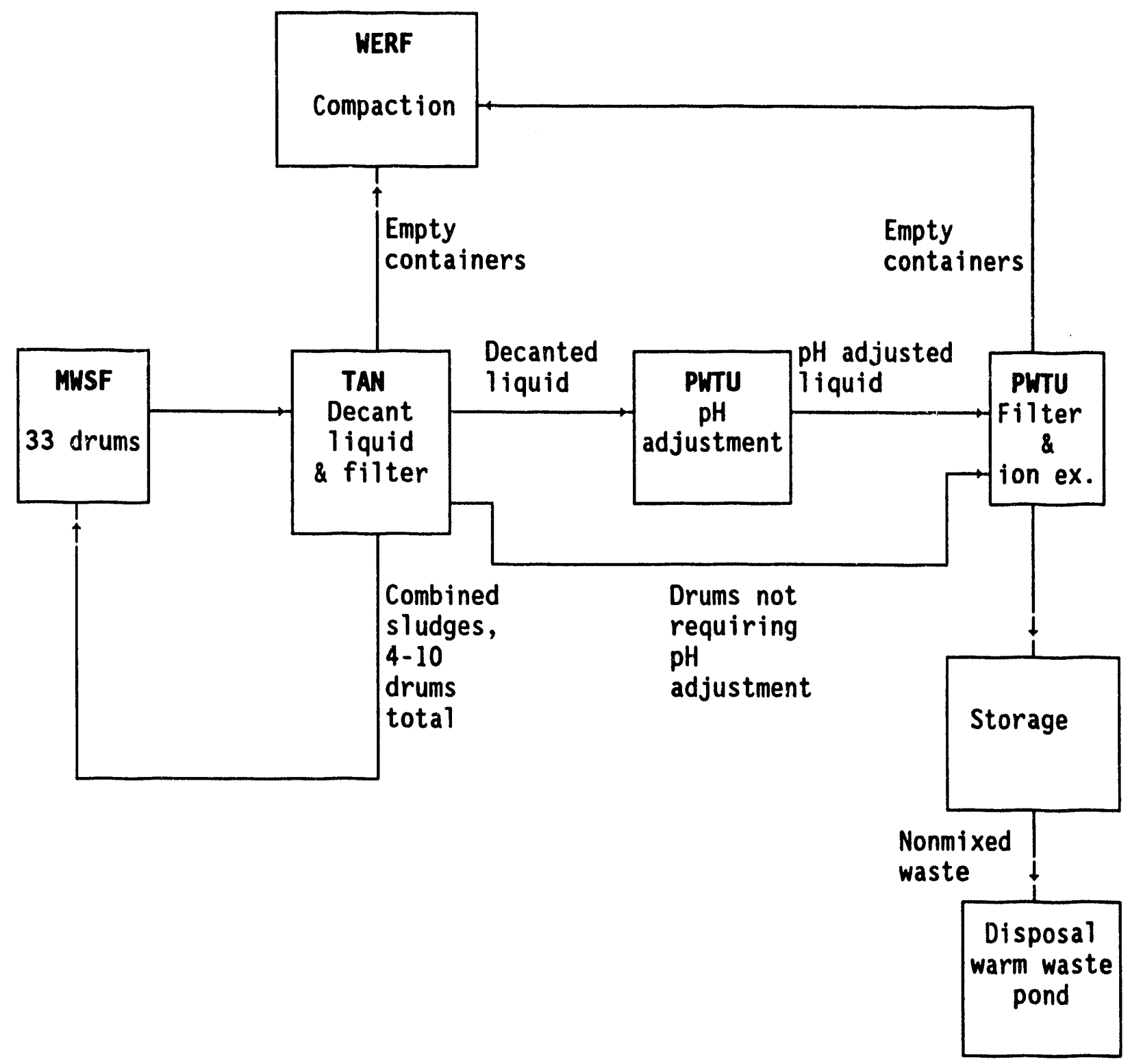

Figure 1. Process flow diagram for the treatment of TAN mercury-contaminated rinse solution. 


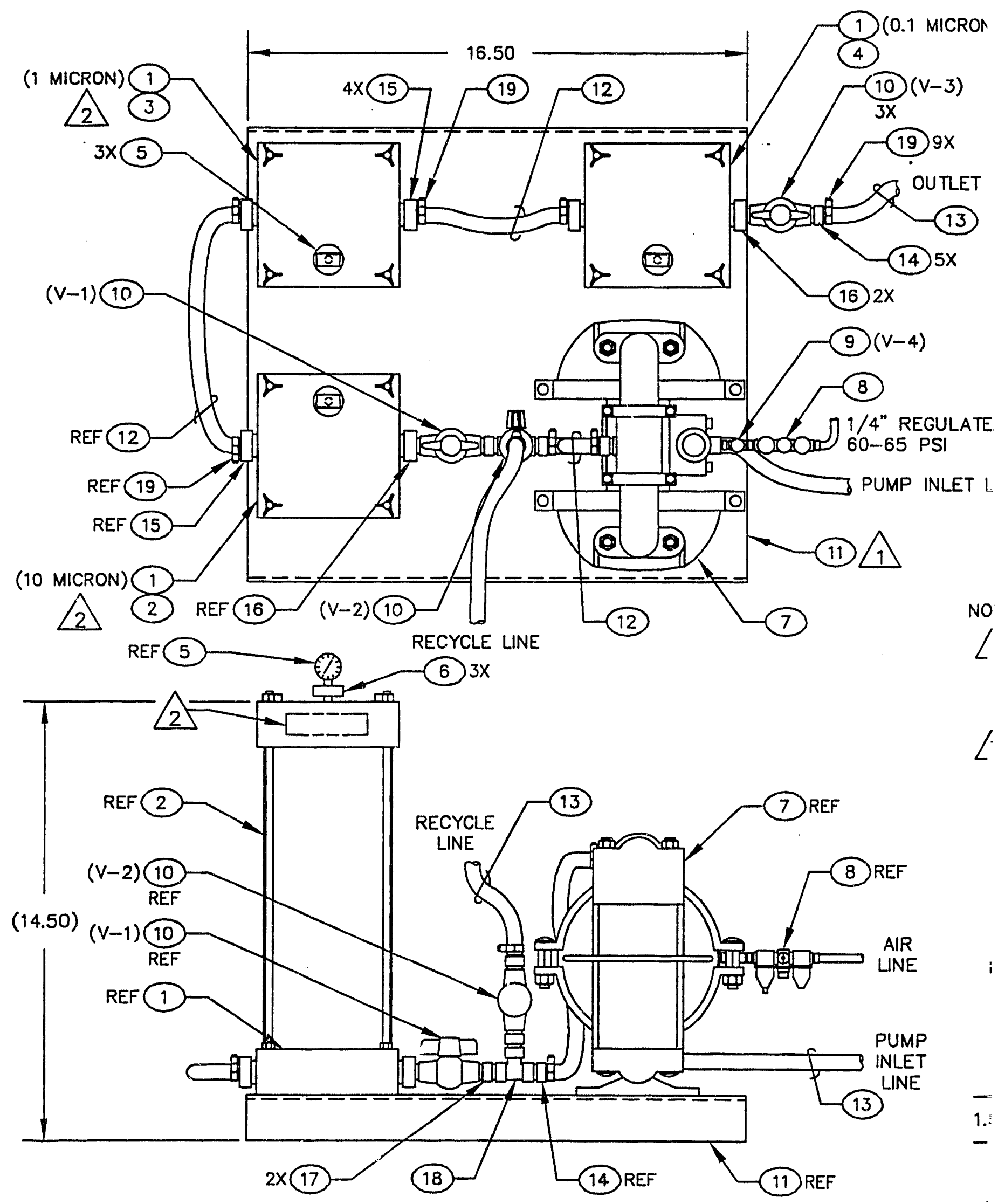

Figure 2. Filter and pump assembly that was used to separate liquid from sludge. 


\begin{tabular}{|c|c|c|}
\hline \multicolumn{3}{|r|}{ PARTS LIST } \\
\hline ITEM & QTY & DESCRIPTION \\
\hline 1 & 3 & $\begin{array}{l}\text { SERFILCO FILTER CHAMBER, SERIES "L" } \\
\text { MODEL \# PPL103/4-G4 }\end{array}$ \\
\hline 2 & 1 & $\begin{array}{l}\text { FILTER CARTRIDGE, ALL WOUND DEPTH FILTER, PPL WTH } \\
\text { PPL CORE, } 10^{\circ} \mathrm{HEIGHT,} 10 \text { MICRON }\end{array}$ \\
\hline 3 & 1 & $\begin{array}{l}\text { FILTER CARTRIDGE, ALL WOUND DEPTH FILTER, PPL WTH } \\
\text { PPL CORE, } 10^{\circ} \text { HEIGHT, } 1 \text { MICRON }\end{array}$ \\
\hline 4 & 1 & $\begin{array}{l}\text { FILTER CARTRIDGE, TRI-PLEATED POLYSULFONE MEMBRANE } \\
\text { MTH PPL SUPPORT, } 10^{\circ} \text { HEIGHT, } 0.1 \text { MICRON }\end{array}$ \\
\hline 5 & 3 & PRESSURE GAUGE, 0-100 PSI \\
\hline 6 & 3 & PRESSURE ISOLATION DIAPHRAGM \\
\hline 7 & 1 & $\begin{array}{l}\text { MLDEN DIAPHRAGM PUMP, } 1 / 2^{n} \text { NPT(F) INLET AND OUTLET, } \\
1 / 4^{*} \text { NPT(F) AIR INLET, MODEL \# M1/PO/PU/PU/KU }\end{array}$ \\
\hline 8 & 1 & MASTER PNEUMATIC $1 / 4^{\prime \prime}$ FRL, FILTER REGULATOR LUBRICATOR \\
\hline 9 & 1 & WHITEY NEEDLE VALVE, $1 / 4^{n}$ \\
\hline 10 & 3 & PVC PLASTIC BALL VALVE, $1 / 2^{\prime \prime}$ NPT(F) INLET AND OUTLET \\
\hline 11 & 1 & PLATE, $1 / 8^{\prime \prime}$ CARBON STEEL \\
\hline 12 & AR & TUBING, $1 / 2^{N}$ ID, REINFORCED TYGON \\
\hline 13 & AR & TUBING, $1 / 2^{n}$ ID, TYGON \\
\hline 14 & 5 & $\begin{array}{l}\text { POLYETHYLENE MALE PIPE ADAPTER, } 1 / 2^{n} \text { NPT(M) } X \\
1 / 2^{n} \text { TUBING }\end{array}$ \\
\hline 15 & 4 & $\begin{array}{l}\text { POLYETHYLENE MALE PIPE ADAPTER, } 3 / 4^{n} \text { NPT(M) } X \\
1 / 2^{\prime \prime} \text { TUBING }\end{array}$ \\
\hline 16 & 2 & PLASTIC PIPE MALE REDUCER, $3 / 4^{n}$ NPT(M) $\times 1 / 2^{n}$ NPT(M) \\
\hline 17 & 2 & PLASTIC PIPE NIPPLE, $1 / 2^{\prime \prime}$ NPT(M) \\
\hline 18 & 1 & PLASTIC PIPE TEE, $1 / 2^{*}$ NPT(F) \\
\hline 19 & 9 & HOSE CLAMPS \\
\hline
\end{tabular}

ITEMS 1 AND 7 TO BE LOCATED ON ITEM 11 APPROXIMATELY AS SHOWN MATCH DRILLED AS REQUIRED.

LABEL ITEM 10 APPROXIMATELY AS SHWON WITH $1 / 8^{n}$ HIGH CHARACTERS. LABEL EITHER 0.1 MICRON, 1 MICRON OR 10 MICRON DEPENDING ON COMPONENT.

EF 7

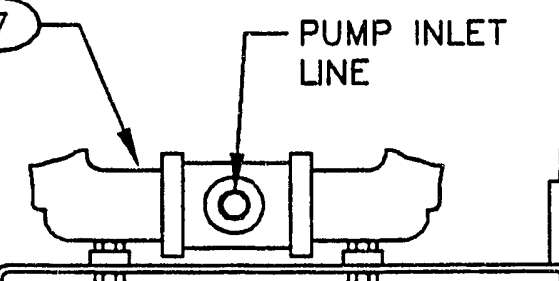

0
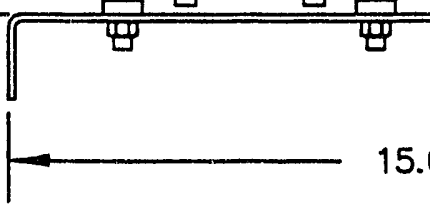

15.00

OUTLET LINIE

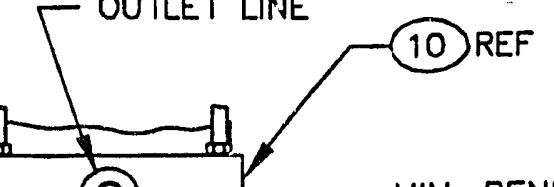

MIN. BEND RADIUS 
on each filter housing provided indication that the filters were working and when the filters became depleted. An air-driven, Wilden diaphragm pump was used to pump the liquid out of the drums and force it through the filters. The diaphragm pump is a positive displacement pump and does not require priming. To ensure that the pump would not overpressurize the filter housings, the supply air was maintained at 65 psig, which is less than the 100 psig pressure rating for the filter system.

Waste drums were brought from the staging area into the Hot Shop in sets of four bound to a pallet. The $\mathrm{pH}$ of each drum was obtained and recorded (see Table 4). The diaphragm pump was used to remove the liquid from the waste drums and pass it through the filtering system (see Figure 2). The flexible inlet line to the pump was connected to a 4-ft length of 5/8-in. stainless steel tubing. The tubing was slowly lowered into the waste drum until the sludge phase was reached. Operators could identify the sludge by observing the fluid flowing through the clear Tygon tubing. Once the liquid was decanted to within 1-2 in. of the sludge phase, the suction line was placed into the next container.

Table 4 shows the drum numbers and information collected on each drum as it was processed. The liquid effluent from the filtering system ranged in colors from clear to brown. The $\mathrm{pH}$ of the effluent was also monitored for each drum (see Table 2). The filtered effluent was discharged into clean polyethylene drums. The drums were placed on a pallet and moved to the staging area at the TAN Hot Shop.

The filters were replaced three times. The first time the filters were replaced when the discharge tube became stained with the waste in Drum 667. There was no sign of solid particulate passing through the filters, indicating that the solution was discolored from dissolved ions. The next two filter change-outs were performed when pressure reading across the filters indicated they were depleted.

2.3.1.3 Sludge Accumulation. After the liquid portion was removed from a set of four drums on a pallet, the sludge from these four drums was then consolidated into a 55-gal steel drum with a polyethylene liner. The sludge solution in the waste drum was mixed by using a small stainless steel propeller on the end of a 3.5 -ft-long shaft. A drill motor was used to drive the mixing shaft and propeller. The sludge was mixed with the 1-2 in. liquid layer that was left during the decanting stage to suspend the solid particulate. The mixed sludge solution was then pumped out of the drum using the assembly shown in Figure 2. Valve 1 was closed to prevent filling the filter housing with sludge and Valve 2 on the recycle line was opened. The end of the recycle line was placed into the sludge accumulation drum. The sludge accumulation drums were filled about two-thirds full. The extra space was left in the drums to provide room to add a solidification agent for future solidification of the sludge. Four sludge accumulation drums were used. Table 4 indicates which sludge from each drum went into each accumulation drum.

After the sludge accumulation drums sat overnight, an attempt was made to decant excess liquid from these drums. However, the operators were unable to distinguish the sludge phase from the liquid phase and no water was removed. 
Table 4. Drums filtered at the TAN Hot Shop and treated at the PWTU.

\begin{tabular}{|c|c|c|c|c|c|c|c|}
\hline $\begin{array}{c}\text { Drum } \\
\text { number }\end{array}$ & $\begin{array}{l}\text { Sampled } \\
\text { prior to } \\
\text { treatment }\end{array}$ & $\mathrm{pH}$ & $\begin{array}{l}\text { Sludge } \\
\text { placed in } \\
\text { drum } \\
\text { number }\end{array}$ & $\begin{array}{c}\text { Drum } \\
\text { number }\end{array}$ & $\begin{array}{l}\text { Sampled } \\
\text { prior to } \\
\text { treatment }\end{array}$ & $\mathrm{pH}$ & $\begin{array}{l}\text { Sludge } \\
\text { placed in } \\
\text { drum } \\
\text { number }\end{array}$ \\
\hline $564^{a}$ & No & 9 & 4 & 626 & No & 10 & 3 \\
\hline 565 & No & 9 & 3 & 627 & No & 10 & 3 \\
\hline 568 & Yes & 11 & 1 & 630 & No & 10 & 3 \\
\hline 569 & No & 8 & 1 & 635 & Yes & 7 & 1 \\
\hline 570 & No & 9 & 1 & 636 & No & 9 & 1 \\
\hline $571^{a}$ & No & 9 & 4 & 637 & No & 9 & 1 \\
\hline $572^{a}$ & Yes & 8 & 4 & 638 & No & 7 & 1 \\
\hline $575^{a}$ & No & 9 & 4 & 666 & No & 10 & 2 \\
\hline $576^{a}$ & No & 11 & 4 & $667^{\mathrm{ab}}$ & No & 9 & 2 \\
\hline 587 & No & 7 & 3 & 668 & No & 10 & 2 \\
\hline $588^{a}$ & No & 10 & 3 & 669 & No & 10 & 2 \\
\hline 589 & No & 10 & 3 & 697 & Yes & 11 & 1 \\
\hline $590^{c}$ & No & 9 & 4 & 700 & No & 3 & No sludge \\
\hline $609^{a}$ & No & 9 & 3 & 701 & No & 3 & 3 \\
\hline 610 & No & 7 & 3 & 702 & Yes & 3 & No sludge \\
\hline 611 & No & 6 & 3 & 703 & Yes & 6 & 3 \\
\hline $612^{a}$ & No & 11 & 2 & & & & \\
\hline
\end{tabular}

a. The solution in these drums had a brown color after filtering down to $0.1 \mu$. The remaining drums had a clear solution after filtering.

b. Drum 667 had 8-10 in. of sludge. Most of the drums had 2-3 in. sludge.

c. Drum 590 had 6-8 in. sludge. Sludge was very thick and damaged the pump. Water was mixed into the sludge as a thinner. The pump was replaced. 
Most of the drums had 2-3 in. of sludge. However, Drum 667 had about 8-10 in. sludge and Drum 590 had 6-8 in. of sludge. Because not enough liquid was left in Drum 590, the sludge was too thick and damaged the pump. The damaged pump was removed and replaced with a new identical pump. About a gallon of water was added to Drum 590 and thoroughly mixed to suspend the sludge. The sludge was then pumped out of Drum $\mathbf{5 9 0}$ without further incident.

After all the sludge had been removed, the empty drums were left bound to the pallets and prepared for shipment to the Waste Experimental Reduction Facility (WERF) for compaction. After compaction, the waste containers will be disposed of at the radioactive waste burial grounds at the INEL.

\subsubsection{Adjustment of $\mathrm{pH}$ at the PWTU}

The $\mathrm{pH}$ adjustment of the wastewater was performed at the PWTU. After the liquid portion of the waste was transferred to clean 55-gal poly drums, the drums were bound four at a time to a pallet and transported to the PWTU with a forklift.

2.3.2.1 Adjustment of pH Requirement. The PWTU has a $\mathrm{pH}$ operating range of 6-9. The scoping studies indicated that the $\mathrm{pH}$ would drop 1-2 points in the ion exchange columns. Therefore, to stay above the $\mathrm{pH}$ limit of 6 , the incoming waste had to be at a $\mathrm{pH}$ of 8 . Although this conflicted with the optimal lead and mercury removal operating range for the resin of a $\mathrm{pH}$ of 4 or less, the scoping studies indicated that 7-8 was an acceptable pH for the incoming waste.

2.3.2.2 Adjustment of pH of the Liquid Waste. Once at the PWTU, the drums were opened one drum at a time. The $\mathrm{pH}$ of the waste in each drum was measured and compared to the $\mathrm{pH}$ measurred during sludge separation. Also, a $150-200 \mathrm{ml}$ sample of the waste in each drum was transferred to a 30 -gal drum to produce a composite mixture of the waste. The composite mixture was sampled, and the sample was sent to Twin City Testing (TCT)c for analysis. After the sample was obtained, acid or caustic was added to each drum as required to adjust the $\mathrm{pH}$ to $7-8$.

As can be seen in Table 2, two of the drums had a pH of 8 , four of the drums had a $\mathrm{pH}$ of 7 , and two of the drums had a $\mathrm{pH}$ of 6 . No $\mathrm{pH}$ adjustment was made to these drums. Three of the drums had a pH of 3 and a $50 \%$ sodium hydroxide solution was added to these drums to raise the $\mathrm{pH}$ to $7-8$. The remaining 22 drums had $\mathrm{pHs}$ of 9-11. Nitric acid was added to these drums to lower the $\mathrm{pH}$ to $7-8$.

Originally, it was anticipated that as nitric acid was added, no precipitation would develop. However, as the acid was added, a precipitate did form. This precipitate was not analyzed because it was not thought to be mercury or lead because both of these compounds should have increased solubility in acid.

c. Twin City Testing (TCT), 1908 Innerbelt Business Center Drive, St. Louis, Missouri 631145700. TCT has been audited by EG\&G Idaho and meets the requirements for an EPA Lab Program for quality assurance and quality control. 
Sulfides where present in the waste, and there was a possibility of generating hydrogen sulfide when the acid was added to the waste. This is a hazardous and flammable gas. The acid was added slowly in 10-ml increments below the surface of the liquid. In this manner the reaction was not vigorous and if any hydrogen sulfide was produced, it remained in solution. There was no noticeable temperature increase in the waste because of the addition of the acid. No hydrogen sulfide was detected by odor during acid additions.

\subsubsection{Filtering and Ion Exchange in the PWTU, Trial 1}

The existing resin columns in the PWTU contain a general cation exchanger. This resin would not be effective at removing mercury to levels below the $0.2 \mathrm{mg} / \mathrm{RCRA}$ limit. To ensure effective mercury and lead removal, heavy metal ion specific resins would have to be used.

The amount of resin required to treat the wastewater was about $0.2 \mathrm{ft}^{3}$ of GT-73. However, with this amount, the flow rate could only be $0.23 \mathrm{gpm}$. Therefore, to decrease operating time, the flow rate was increased by using an excess of resin. Two resin columns were purchased, each with a $0.5 \mathrm{ft}^{3}$ bed volume, giving a total bed volume of $1.0 \mathrm{ft}^{3}$. Detailed resin column information is found in Appendix C. This bed volume permitted a flow rate of $1.2 \mathrm{gpm}$, which required three days to process the waste. Processing time could be further reduced by increasing the resin capacity, but at the expense of generating more radioactive waste.

Treatability results suggested the best resin to use was GT-73. However, it was no longer being manufactured and not available. About $7,000 \mathrm{~g}\left(0.28 \mathrm{ft}^{3}\right)$ was purchased from a lab supply company, but the remaining $0.72 \mathrm{ft}^{3}$ of bed volume had to be filled with S-920. The GT-73 was placed at the bottom of the second column to act as a polishing resin because the scoping studies indicated it was the more effective resin. Once the columns were packed, they were installed into the system. The columns were installed into a bypass line around the activated carbon beds. The activated carbon beds were not usable while the columns were installed.

Once a drum of waste on a pallet had the $\mathrm{pH}$ adjusted to $7-8$, the solution was pumped from the drum using a peristaltic pump. The solution was punped from the drums at a rate of 1.2-1.4 gpm as measured on the two flow meters/totalizers in the process trailer. The waste was fed to the inlet of the PWTU shown in drawing number 177148 in Appendix A. The solution was filtered through $20-\mu$ filters into the heavy metals ion exchange columns. Originally, the waste was fed through the general cationic ion exchange columns to remove the radioactive isotopes. However, the solution became very acidic in these columns. It was decided to bypass these columns and only go through the temporary heavy metal removal columns. After the waste was completely treated in the heavy metal columns, the waste was then processed through the general cation exchange resin to remove the radioactive isotopes. The treated waste was discharged to two tanks, each containing about 900 gal.

The pressure drop across the temporary heavy metal columns slowly increased during processing. When the inlet pressure reached about $40 \mathrm{psig}$, the system was shut down and the first column was dismantled. Precipitated material formed during $\mathrm{pH}$ adjustment was passing through the 20- $\mu$ filters and collecting in the ion exchange columns, causing the columns to restrict the flow. The resin in the first column was removed and replaced with fresh resin. The system continued operation until about five drums remained, at which time the columns again 
became too plugged to continue operations. Both columns were then back flushed. After back flushing, the remaining drums of waste were treated.

The process initially passed the water through both the heavy metals resin and the radioactive ion exchange resin. However, the discharged solution was at a $\mathrm{pH}$ of less than 3 . The radioactive removal columns were designed for a much higher flow rate, and it was decided that the slow $1.2 \mathrm{gpm}$ flow rate was allowing too much ion exchange, resulting in the $\mathrm{pH}$ of the water being driven down. The radioactive columns were bypassed after about 300 gal was processed. With the waste going through the heavy metals column only, the $\mathrm{pH}$ stabilized at 7-8. The final waste was placed into two tanks. The first tank had the initial 300 gal of acidic water discharged to it, plus about $600 \mathrm{gal}$ of water at $\mathrm{pH} 7-8$. The final $\mathrm{pH}$ of this tank was less than 3. The solution was neutralized by adding $50 \mathrm{wt} \%$ sodium hydroxide. Mixing was provided by recycling the water at $140 \mathrm{gpm}$ through a pump. The waste in the second tank was at a $\mathrm{pH}$ of 7 . This wastewater was slightly turbid, indicating some solid particles probably had passed through the filters and resin columns.

The PWTU was reconfigured so wastewater would flow through the activated carbon beds and the three general cation, $\mathrm{C}-100 \mathrm{H}$, exhange resin columns. The wastewater in the two tanks was then reprocessed in the PWTU at the system design flow rate of 8-10 gpm. The wastewater was processed through the activated carbon beds only to bypass the temporary heavy metal ion exchange columns and not to remove any organics. As the waste was processed through the $\mathrm{C}-100 \mathrm{H}$ ion exchange columns, the $\mathrm{pH}$ of the waste dropped to less than 3 , and the in-line automatic $\mathrm{pH}$ adjustment unit could not increase the $\mathrm{pH}$. The treated solution in the tanks was cloudy, indicating precipitation was in the tanks. The bulk solution in the tanks was at a $\mathrm{pH}$ of less than 3. The solution was neutralized in the tanks. A pump was connected to recycle the solution in the tanks at about $140 \mathrm{gpm}$. Solid sodium hydroxide was then slowly added to increase the $\mathrm{pH}$. As the sodium hydroxide was added, a great deal of precipitate formed. The final $\mathrm{pH}$ of the solution was at 9 . The precipitate was not analyzed, but was assumed to be aluminum or sodium, both of which may pass through the resin columns.

\subsubsection{Sampling and Analysis Results of pH Adjustment and Ion Exchange, Trial 1}

Samples of the treated wastewater were obtained for radioactive analysis at the Radiation Measurements Laboratory (RML) located at the INEL, and were analyzed for TCLP metals, TCLP pesticides, and TCLP herbicides at TCT. A sample was also sent to the Environmental Chemistry Unit (ECU) lab located at the INEL for total RCRA-regulated metals screen. Gamma-ray results are shown in Table 5 and detailed lab results are provided in Appendix D. TCLP test results from TCT are summarized in Table 6 and detailed lab results are provided in Appendix E. Table 6 also shows the results of TCLP metals testing from ECU. The results are divided into Tanks 1 and 2 , because the waste was placed into two tanks after treatment.

As can be seen by the results in Table 5, the original waste had a total activity of $2.1 \mathrm{pCi} / \mathrm{ml}$. This is from a sample of the consolidated liquid representing the bulk waste. After treatment, the total activity was reduced to $0.269 \mathrm{pCi} / \mathrm{ml}$. The original waste contained only $\mathrm{Co}-60$; however, after treatment the waste stream registered the presence of Cs-137. The Co-60 was reduced to $0.046 \mathrm{pCi} / \mathrm{ml}$, but the Cs-137 increased $0.223 \mathrm{pCi} / \mathrm{ml}$, accounting for the majority of the radioactivity in the final waste solution. The cesium probably was removed from the resin 
Table 5. Radioactive contamination of consolidated sample of treated liquid waste.

\begin{tabular}{llll}
\hline \multicolumn{1}{c}{ Waste form } & \multicolumn{1}{c}{$\begin{array}{c}\text { Activity by isotope } \\
(\mathrm{pCi} / \mathrm{ml})\end{array}$} & \multicolumn{1}{c}{$\begin{array}{c}\text { Total activity } \\
(\mathrm{pCi} / \mathrm{ml})\end{array}$} \\
\hline $\begin{array}{l}\text { Untreated consolidated liquid } \\
\text { (180-200 ml collected from }\end{array}$ & Co-60 & $2.10 \pm 0.03 \mathrm{E}+0$ & $2.10 \pm 0.03 \mathrm{E}+0$ \\
$\begin{array}{l}\text { each waste drum after } \\
\text { filtration) }\end{array}$ & & & \\
Treated liquid, Tank $1^{\mathrm{a}}$ & $\mathrm{Co}-60$ & $5.2 \pm 0.5 \mathrm{E}-2$ & \\
& $\mathrm{Cs}-137$ & $1.59 \pm 0.07 \mathrm{E}-1$ & $2.11 \pm 0.07 \mathrm{E}-1$ \\
Treated liquid, Tank $2^{\mathrm{a}}$ & $\mathrm{Co}-60$ & $5.1 \pm 0.5 \mathrm{E}-2$ & \\
& $\mathrm{Cs}-137$ & $2.31 \pm 0.08 \mathrm{E}-1$ & $2.82 \pm 0.08 \mathrm{E}-1$ \\
& $\mathrm{Co}-60$ & $4.6 \pm 0.5 \mathrm{E}-2$ & \\
Treated liquid, & $\mathrm{Cs}-137$ & $2.23 \pm 0.08 \mathrm{E}-1$ & $2.69 \pm 0.08 \mathrm{E}-1$ \\
Tanks 1 and 2 & &
\end{tabular}

a. The waste originally contained in $\mathbf{3 3}$ drums was discharged to two storage tanks from the PWTU.

columns in the PWTU. Cesium is an ion that is very difficult to remove by ion exchange. When the waste that contained a great deal of calcium and sodium ions was run through the ion exchange resin that had radioactive cesium already loaded on, the calcium and possibly some of the sodium replace the radioactive cesium on the active site of the resin, releasing the cesium to the wastewater solution.

The first metal results from ECU indicated that the mercury levels were reduced from 7.0 $\mathrm{mg} /$ to an average of $1.39 \mathrm{mg} /$, which is greater than the $0.2 \mathrm{mg} / \mathrm{RCRA}$ limit. There was a large difference in values from Tank 1 at $1.9 \mathrm{mg} / \mathrm{l}$ to Tank 2 at $0.882 \mathrm{mg} /$. Results from TCT arrived about a week later, and indicated that the mercury was barely above the RCRA limit in Tank 1 at $0.264 \mathrm{mg} / \mathrm{l}$ and well below the RCRA limit in Tank 2 at $0.0087 \mathrm{mg} /$. There was a large discrepancy in values between the two labs' results.

The analysis methods of TCT and ECU were compared to evaluate why there was such a large discrepancy between the two labs' results. ECU was not following RCRA requirements for testing. It was acidifying the sample and then filtering, while TCT was filtering the sample and then doing the acid digestion. As a result, TCT was removing solid mercury compounds such as mercury oxide with the filtering, while ECU was putting the solid mercury into solution by acidification. This consistently produced higher metal results from ECU.

As can be seen by the results of TCLP metals in Table 6 Trial 1, mercury was not reduced to levels less than the RCRA limit of $0.2 \mathrm{mg} /$. As a result, the liquid waste was reprocessed two more times resulting in the Trial 2 and 3 results. Trial 2 and 3 results will be discussed in detail in the following sections. 
Table 6. Mercury and lead concentrations of untreated waste and treated waste after each trial.

\begin{tabular}{|c|c|c|c|c|}
\hline \multirow{3}{*}{$\begin{array}{l}\frac{\text { Treatment }}{\text { Untreated consolidated }} \\
\text { liquid ( } 180 \text { to } 200 \mathrm{ml} \\
\text { collected from each waste } \\
\text { drum after filtration) }\end{array}$} & \multicolumn{2}{|c|}{$\begin{array}{l}\text { Mercury } \\
\text { TCT/ECU } \\
(\mathrm{mg} / \mathrm{l})\end{array}$} & \multicolumn{2}{|c|}{$\begin{array}{l}\text { Lead } \\
\text { TCT/ECU } \\
(\mathrm{mg} / \mathrm{l})\end{array}$} \\
\hline & \multicolumn{2}{|c|}{$7.000^{b}$} & \multicolumn{2}{|c|}{$2.780^{b}$} \\
\hline & Tank $1^{c}$ & Tank $2^{c}$ & Tank $1^{c}$ & Tank $2^{\mathfrak{c}}$ \\
\hline $\begin{array}{l}\text { Treated liquid Trial } 1 \\
\text { (filtered to } 20 \mu \text { then passed }\end{array}$ & $0.264 /$ & $0.0087 /$ & $0.022 /$ & $0.104 /$ \\
\hline $\begin{array}{l}\text { through S-920, GT- } 73 \text {, and } \\
\text { C-100H resins) }\end{array}$ & 1.900 & 0.882 & 0.150 & 0.240 \\
\hline $\begin{array}{l}\text { Treated liquid Trial } 2 \\
\text { (Filtered to } 0.1 \mu \text {, } \\
\text { no ion exchange) }\end{array}$ & $\begin{array}{l}0.864 / \\
1.380^{d}\end{array}$ & $\begin{array}{l}1.788 / \\
1.380^{d}\end{array}$ & $\begin{array}{l}\text { No data } \\
\text { collected }\end{array}$ & $\begin{array}{l}\text { No data } \\
\text { collected }\end{array}$ \\
\hline $\begin{array}{l}\text { Treated liquid Trial } 3 \\
\text { (filtered to } 0.3 \mu \text { then } \\
\text { passed through S- } 920 \text { resin) }\end{array}$ & $\begin{array}{l}0.0092 / \\
0.0156\end{array}$ & $\begin{array}{l}0.0168 / \\
0.033\end{array}$ & $\begin{array}{l}\text { No data } \\
\text { collected }\end{array}$ & $\begin{array}{l}\text { No data } \\
\text { collected }\end{array}$ \\
\hline
\end{tabular}

a. TCT - Twin City Testing Corporation.

ECU - Environmental Chemistry Unit lab at the INEL.

b. These are TCT lab results only; a sample of the untreated consolidated liquid was not sent to ECU for analysis.

c. The waste originally contained in 33 drums was discharged to two storage tanks from the PWTU. The samples were labeled Storage Tank 1 or 2 , but Tanks 1 and 2 are not necessarily the same storage tanks between processing trials.

d. Sample sent to ECU lab was a mixture of approximately equal amounts from each tank.

Lead already started out below the RCRA limit of $5.0 \mathrm{mg} /$, but concentrations were reduced by the treatment in the heavy metals ion exchange column. Results from ECU indicate that lead levels were reduced from $2.78 \mathrm{mg} /$ to an average of $0.195 \mathrm{mg} /$. Results from TCT indicate that lead levels were reduced from $2.78 \mathrm{mg} / \mathrm{l}$ to an average of $0.063 \mathrm{mg} /$. Again, the values from TCT and ECU were significantly different.

An evaluation was made to determine what may have caused the treatment to fail at reducing the mercury to RCRA limits, and what could be done to successfully process the waste. Three possibilities exist for the presence of the mercury in the treated wastewater. The first 
possibility is that the precipitated material from the three acidic drums contained mercury oxides, and insufficient filtration then allowed the mercury compounds to be contained in the treated waste stream. The second possibility is that the precipitated material that lodged in the resin columns also plugged the active sites on the resin, making the resin ineffective. The third possibility is that the resin was not effective at removing the mercury ions. Of these three possibilities, it was believed that the first one was the most likely reason for the high mercury levels in the treated waste. To help evaluate which scenario occurred, the remaining liquid sample that was taken for ECU analysis was filtered with a $0.45-\mu$ filter and reanalyzed. The filtering of the sample lowered the mercury level to $0.025 \mathrm{mg} /$, which is below the RCRA limit, indicating that solid particulate is responsible for the high mercury content.

\subsection{Reprocessing by Filtration, Trial 2}

\subsubsection{Reprocessing by Filtration, Trial 2}

After verification that filtering the sample was an effective treatment, a method to filter the wastewater was developed. The filtering unit shown in Figure 2 was installed in the PWTU. The last two filter housings were used and were plumbed to the system the same way the temporary ion exchange columns were installed. Also, $0.3-\mu$ filters were purchased and installed into the permanent filter housings in the PWTU. The two temporary filter housings were filled with $0.1-\mu$ filters. The end result was that the waste was filtered through $0.3-\mu$ filters, then into a $0.1-\mu$ filter, and finally into another $0.1-\mu$ filter. The activated carbon beds and the radioactive ion exchange columns were bypassed. The only treatment performed was filtration.

The waste was filtered through the system at a flow rate of about $6 \mathrm{gpm}$. There was about $1 / 2$ to 1 in. of sludge at the bottom of the tanks. The sludge was not very compact and was easily suspended. The waste in both tanks was filtered down to a few inches above the sludge, so as not to stir up the sludge and require frequent filter changes during processing. After the liquid was removed from both tanks down to within a few inches of the sludge, the suction line was lowered into the sludge and the sludge was suspended. All the waste in both tanks was removed and the sludge material collected on the filters. The tanks were thoroughly rinsed with water and the rinse water was filtered. The filtered waste was discharged from the system to two polyethylene tanks. The $0.3-\mu$ filters required seven change-outs to process the liquid, resulting in use of 14 filters. The first $0.1-\mu$ filter in the series had to be changed out once. The second $0.1-\mu$ filter did not require any change-outs. Upon dismantling of the filter system after all the waste was filtered, a very fine black precipitate was observed on the last $0.1-\mu$ filter. The $0.3-\mu$ filters collected about $90-99 \%$ of the particulate. The sludge on these filters looked like caramel. The sludge on the two $0.1-\mu$ filters that were removed from the second housing was all black. The discharge liquid from the PWTU was very clear.

Prior to the start of filtering, the $\mathrm{pH}$ of the solution was measured at 6. Approximately one week had passed from the time of sampling to the time of filtering the waste. Therefore, in a period of about a week, the $\mathrm{pH}$ of the waste in both tanks went from 9 down to 6 . 


\subsubsection{Sampling and Analysis Results of Filtration, Trial 2}

The sampling and analysis results of Trial 2 wastewater are shown in Table 6. Because sampling and analysis results from Trial 1 indicate that there are no TCLP pesticides, TCLP herbicides, and volatile organics, and because mercury was the only RCRA-regulated metal identified in the waste, the filter-treated wastewater was analyzed for mercury only. Samples were sent to both ECU and TCT labs. The sample sent to ECU was an equal mixture of waste from both tanks. Samples from each tank were sent to TCT. The first results were obtained from ECU, but because of the large discrepancy between the two labs' results in the previous trial, it was decided to wait until TCT's results arrived before taking any action. As can be seen in Table 6, the results from both labs are very close. The average value for the two tanks from TCT is $1.326 \mathrm{mg} /$. The result from the mixed solution from ECU is $1.380 \mathrm{mg} /$. The values indicate that not only is the waste above the RCRA limit of $0.2 \mathrm{mg} /$, the average concentration of mercury in the waste increased from the Trial 1 treatment.

The increase in mercury in the solution is assumed to have come from an equilibrium adjustment of the waste as it sat for a week between Trial 1 and Trial 2 processing. During this equilibrium adjustment, a precipitated mercury complex that went through the $20-\mu$ filters and the resin columns probably went back into solution. There are three pieces of evidence to support this theory. First, the $\mathrm{pH}$ of the solution went from 9 down to 6 while sitting in the tanks for a week; this can only occur if ions either go into or out of solution. Second, the filtering of the ECU sample while still at a $\mathrm{pH}$ of 9 indicated that filtering would remove the mercury. Third, ECU results and TCT results were very close, indicating that the mercury was in solution when the samples were taken.

Analysis of the data from ECU and TCT showing high levels of mercury, combined with the fact that the liquid waste has been thoroughly filtered and is free of solids, indicates that the mercury is probably in solution. Whether or not this mercury was in solution after the initial treatment is difficult to tell, but it seems most likely that a mercury complex that was a solid at a pH of 9 went back into solution at a pH of 6 .

\subsection{Reprocessing by Filtering and Ion Exchange, Trial 3}

\subsubsection{Reprocessing by Filtering and Ion Exchange, Trial 3}

Because the treatability studies demonstrated that the ion exchange with S-920 works, it was decided to run the waste through the heavy metal ion exchange columns for a second time. In conjunction with this, the waste would be filtered through $0.3-\mu$ filters.

The old resin in the two temporary columns was removed and placed into a drum. New S-920 resin was then packed into the resin columns. The temporary columns were plumbed into the system as they were in Trial 1. The permanent filter housings in the PWTU were fitted with $0.3-\mu$ filters. The waste was processed at a flow rate of $1.2-1.4 \mathrm{gpm}$. The activated carbon beds and the radioactive ion exchange columns were bypassed.

A period of about three weeks had elapsed between the time of completing Trial 2 processing and the start of Trial 3 processing. Over that time the waste was becoming cloudy. 
Originally, it was thought to possibly be something precipitating out as the water cooled, because night-time temperatures were averaging about $30^{\circ} \mathrm{F}$. However, by the time Trial 3 processing started, it was obvious that the cloudiness was being caused by the growth of algae in the water.

The wastewater was pumped out of the storage tanks using the peristaltic pump used in Trial 1 processing. The waste was pumped at a flow rate of $1.2-1.4 \mathrm{gpm}$, again dictated by the volume of the resin. During processing of the waste, there was no pressure increase on the ion exchange columns due to clogging. Also, there was very little pressure increase on the filters and only one set of filters was required to process all the waste. The tanks were thoroughly rinsed with clean water, and this rinse solution was processed through the PWTU. The discharge came out clear. The waste was discharged to two polyethylene tanks identical to the ones used previously. When the filters were removed, they were coated with a green brown algae material. The resin in the columns appeared to stay clean, and no particulate was observed in them.

\subsubsection{Sampling and Analysis Results of Filtering and Ion Exchange, Trial 3}

The sampling and analysis results of Trial 3 are shown in Table 6. Again, only mercury was analyzed. The results from both labs indicate that mercury is below the RCRA limit. The highest values are from ECU at $0.0156 \mathrm{mg} / 1$ and $0.033 \mathrm{mg} /$, respectively. The values from TCT are roughly half ECU values at $0.00919 \mathrm{mg} /$ and $0.0186 \mathrm{mg} /$, respectively. These values are higher than the $0.0056 \mathrm{mg} / \mathrm{l}$ obtained from the treatability studies.

\subsubsection{Wastewater Disposal}

The wastewater was ultimately disposed of by discharging to the TAN warm waste pond TAN782, TSF-10. The final volume of solution treated was about 2,000 gal. This includes the original $1,800 \mathrm{gal}$ of waste plus about $200 \mathrm{gal}$ of water used to rinse the storage tanks and lines.

\subsection{Sampling and Analysis of Filters and Resins}

In the process of treating the TAN mercury-contaminated rinse solution waste, several components became contaminated with radioactivity and hazardous waste. The resin columns and the pump and filter unit will be saved and used to treat wastes in the future. The depleted filters and the resins used in the temporary heavy metal ion exchange columns were placed into drums. The filters and the resins were sampled to determine if they were a mixed waste or a radioactive waste only. The results of the sampling and analysis of the filters and resin are detailed below.

\subsubsection{Sampling and Analysis Results of Filters}

A total of 32 filters were used in the processing of the TAN mercury-contaminated rinse solution wastewater. Of these 32 filters, 12 of the dirtiest filters were sampled. The filters were sampled following the procedures in the PWTU sampling and analysis plan, which includes a section for filter sampling. A knife was used to cut a $6 \times 8$-in. section of the filtering material off of the filter support. This was then cut into three strips; then each strip was placed into one of three containers. This was repeated for each of the 12 filters that were sampled, resulting in a strip from all 12 filters being combined to produce three composite samples. The composite samples were sent to TCT to be analyzed for TCLP metals, TCLP pesticides, TCLP herbicides, 
TCLP volatiles, and corrosivity. A sample was also sent to RML for gamma-ray analysis. Table 7 shows the mercury and lead TCLP results. The original TCT data are provided in Appendix E. The filters failed to meet the RCRA limit for both lead and mercury. The filters passed on all the other metals and no volatiles, pesticides, or herbicides were detected. Samples of the original sludge passed TCLP mercury, but failed TCLP lead. The reason that the sludge collected on the filters did not pass TCLP mercury is probably because of the generation of mercury oxide or other mercury complex during $\mathrm{pH}$ adjustment.

Table 8 shows the activity of the sludge collected on the filters. Most of the activity is from Co-60, with an average activity of $235 \mathrm{pCi} / \mathrm{g}$. This kind of activity was expected to collect in the filters because the treatability studies demonstrated that most of the activity was concentrated in the sludge.

\subsubsection{Sampling and Analysis Results of Resins}

A total of about $1.3 \mathrm{ft}^{3}$ of resin was used in the Trial 1 processing. The resins were sampled following the PWTU sampling and analysis plan. The resin was placed into a drum, thoroughly mixed, and then a scoop was used to take the samples. This produced a composite sample of the resin used in Trial 1 . The resin used in Trial 3 processing was added to this waste container after the sampling and analysis. Some of the samples were sent to TCT to be analyzed for TCLP metals, TCLP pesticides, TCLP herbicides, TCLP volatiles, and corrosivity. A sample was also sent to RML for gamma-ray analysis. Table 7 shows the mercury and lead TCLP results. The original TCT results are provided in Appendix E. As can be seen, the resin failed to meet the RCRA limits for both lead and mercury. The resin passed on all the other metals and no volatiles, pesticides, or herbicides were detected.

Table 8 shows the activity of the resin. Most of the activity is from Co-60, with an average activity of $270 \mathrm{pCi} / \mathrm{g}$. This activity may be primarily from the solid particulate that passed through the filters and was collected in the resin. The activity is also due in part to the cobalt and silver ions being removed from solution onto the resin.

The resins used in the treatability studies were tested for TCLP metals. This resin passed TCLP tests. This indicates that the reason the resin used to treat the bulk liquid failed TCLP metals testing is due to the sludge material that passed through the filtering system and became entrained in the resin. 
Table 7. Mercury, lead, and chromium TCLP and corrosivity results from TCT lab.

\begin{tabular}{lllll}
\hline \multicolumn{1}{c}{ Waste form } & $\begin{array}{c}\text { Mercury } \\
(\mathrm{mg} / \mathrm{l})\end{array}$ & $\begin{array}{c}\text { Lead } \\
(\mathrm{mg} /)\end{array}$ & $\begin{array}{c}\text { Chromium } \\
(\mathrm{mg} /)\end{array}$ & $\begin{array}{c}\text { Corrosivity } \\
(\mathrm{mm} / \mathrm{yr})\end{array}$ \\
\hline $\begin{array}{l}\text { Resin } \\
\text { Sample 1 }\end{array}$ & 2.1 & 141 & 0.141 & $2.6 \mathrm{E}-4$ \\
$\begin{array}{l}\text { Resin } \\
\text { Sample 2 }\end{array}$ & 2.74 & 3.12 & 0.14 & $4.5 \mathrm{E}-4$ \\
$\begin{array}{l}\text { Filters } \\
\text { Sample 1 }\end{array}$ & 3.64 & 329 & 0.983 & $1.8 \mathrm{E}-4$ \\
$\begin{array}{l}\text { Filters } \\
\text { Sample 2 }\end{array}$ & 1.55 & 344 & 2.21 & $2.1 \mathrm{E}-4$ \\
\hline
\end{tabular}

Table 8. Radioactive contamination in ion exchange resin and filters.

\begin{tabular}{llll}
\hline \multicolumn{1}{c}{ Waste form } & \multicolumn{2}{c}{$\begin{array}{c}\text { Activity } \\
\text { (pCi/g) }\end{array}$} & $\begin{array}{c}\text { Total activity } \\
\text { (pCi/g) }\end{array}$ \\
\hline $\begin{array}{lll}\text { Resins (sampled } \\
\text { from columns) }\end{array}$ & $\mathrm{Co}-60$ & $2.64 \pm 0.03 \mathrm{E}+2$ & $2.65 \pm 0.03 \mathrm{E}+2$ \\
Resins (sampled & $\mathrm{Ag}_{\mathrm{m}}-108$ & $10.0 \pm 0.08 \mathrm{E}-1$ & \\
from drum) & $\mathrm{Co}-60$ & $2.69 \pm 0.04 \mathrm{E}+2$ & $2.7 \pm 0.04 \mathrm{E}+2$ \\
Filters & $\mathrm{Ag}_{\mathrm{m}}-108$ & $9.9 \pm 0.07 \mathrm{E}-1$ & \\
& $\mathrm{Co}-60$ & $2.19 \pm 0.03 \mathrm{E}+2$ & $2.29 \pm 0.03 \mathrm{E}+2$ \\
& $\mathrm{Ag}_{\mathrm{m}}-108$ & $2.48 \pm 0.04 \mathrm{E}+0$ & \\
& $\mathrm{Cs}-137$ & $7.26 \pm 0.16 \mathrm{E}+0$ & \\
Filters & $\mathrm{Eu}-152$ & $6.3 \pm 0.7 \mathrm{E}-1$ & \\
& $\mathrm{Co}-60$ & $2.31 \pm 0.03 \mathrm{E}+2$ & $2.42 \pm 0.03 \mathrm{E}+2$ \\
& $\mathrm{Ag}-108$ & $2.81 \pm 0.05 \mathrm{E}+0$ & \\
& $\mathrm{Cs}-137$ & $8.16 \pm 0.11 \mathrm{E}+0$ & \\
& $\mathrm{Eu}-152$ & $6.4 \pm 0.7 \mathrm{E}-1$ & \\
\hline
\end{tabular}




\section{CONCLUSIONS}

Initial separation of the liquid from the solid portion of the waste using the pump and filter system shown in Figure 2 worked very well. This system was also effective at pumping the sludge slurry to consolidate the sludge in the $\mathbf{3 3}$ original waste containers to four drums. The filter housings shown in Figure 2 are designed to replace the filter without draining the housings by removing the top of the housing. However, placing the filters into these housings and ensuring a proper seal between the filter and housing was very difficult because the filters would float in the wastewater.

Adjustmert of $\mathrm{pH}$ of the waste in the drums is slow, poses several hazards, and should not be considered for normal operations. The addition of the acid in 10-ml increments through a pipet required a great deal of operator interaction with the concentrated nitric acid. Manual stirring of the waste with a stirring rod between each acid addition required a great deal of labor interaction and increased the potential for spills and splashing.

The unexpected amount of precipitation produced during $\mathrm{pH}$ adjustment and the inadequate filtering by the $20-\mu$ filters resuited in particulate reaching the resins and the treated waste storage tanks. It is likely that the addition of sodium hydroxide to the three acidic drums produced mercury oxide or possibly a mercury complex that passed through the filtration system and the resin colunns, and resulted in the failure of the Trial 1 treatment to reduce mercury concentrations to the required levels.

The filtering of the waste in Trial 2 treatment was ineffective. The $\mathrm{pH}$ of the waste had decreased from 9 to 6 . This probably resulted in the mercury oxide or a mercury complex dissolving into solution, making filtration ineffective. The sample of the Trial 1 treated waste did not undergo the same spontaneous $\mathrm{pH}$ change, probably because an insufficient amount of precipitated material was in the sample to allow the same equilibrium reaction to occur.

The ion exchange treatment with proper filtration of the waste in Trial 3 effectively treated the waste and reduced the mercury levels to $0.0186 \mathrm{mg} /$. The $\mathrm{S}-920 \mathrm{resin}$ is an effective resin to reduce mercury levels to less than the RCRA limit of $0.2 \mathrm{mg} /$, but may not be capable of attaining drinking water standards of $0.002 \mathrm{mg} /$.

The final liquid waste solution was below the RCRA limit for mercury at less than $0.0186 \mathrm{mg} / \mathrm{l}$ and for lead at less than $0.240 \mathrm{mg} /$. Radioactivity levels were less than $0.282 \mathrm{pCi} / \mathrm{ml}$, which is le:s than the detived concentration guideline (DCG) values for Cs-137 and Co-60 at 3 $\mathrm{pCi} / \mathrm{ml}$ and $5 \mathrm{pCi} / \mathrm{ml}$, respectively. The waste was finally disposed of by discharging it into the swarm waste pond at TAN.

The filters produced from this process are a mixed waste. Ultimate disposal will probably be incineration at WERF.

The solid particulate matter did not appear to affect the resin's ability to remove dissolved mercury and lead ions becalse there was a definite decrease between the concentrations of the 
treated waste over the nontreated waste. However, the solid particulate matter that was entrained in the resin probably resulted in the resin's failure to pass TCLP. It is likely the resin from Trial 3 and future resins would pass TCLP if proper filtration were employed, because the resins in the treatability studies passed TCLP. 


\section{RECOMMENDATIONS}

\subsection{PWTU Changes}

The treatment of the TAN mercury-contaminated rinse solution demonstrates that ion exchange is an effective treatment of mixed waste solutions containing dissolved ions. However, this treatment demonstration also pinpoints several deficiencies in the existing PWTU. The areas of concern that have been identified from the testing are:

- The inability to treat the waste at one location

- The hazards associated with $\mathrm{pH}$ adjustment of the waste while contained in the waste drum

- The limited acceptable $\mathrm{pH}$ range for wastes

- The inability of the pumping, piping, and filtration systems to handle very fine particulate

- The inability to allow increased resin capacity or addition of different resins without having to make piping changes to the system

- The inability of the system to adjust the $\mathrm{pH}$ of the treated waste prior to discharging the waste from the PWTU.

Each one of these concerns are addressed in detail below.

\subsubsection{Permitting and Safety Documentation Changes}

To perform the treatment of this waste, Part A of the RCRA permit had to be expanded to include waste codes D008 and D009 for lead and mercury, respectively. To continue processing mixed wastes, the PWTU permits must be modified. An evaluation must be performed to determine the hazardous materials in existing wastes at the INEL and the potential hazardous material that may be in future wastes. The RCRA and State permits should then be expanded to include the identified hazards. Also, the current safety documentation is very restrictive. To treat the TAN mercury-contaminated rinse solution, the sludge had to be removed at a separate location. This created the added hazard of transporting the waste from one location to another. An evaluation shouic be made of the PWTU SAR and hazard classification and compare this to wastes identified for potential treatment and future wastes that may be treated. Modifications should then be made to this documentation to ensure that the safety envelope covers as wide of a variety of wastes as possible.

\subsection{2 pH Adjustment System Addition}

For the purposes of demonstration testing, the $\mathrm{pH}$ adjustment of wastewater in the waste drum is acceptable. However, for regular day-to-day processing, this would not be an acceptable 
practice. To ensure the safe processing of future waste streams, a pH adjustment system is required. The $\mathrm{pH}$ adjustment system must be capable of neutralizing both acidic and caustic solutions. The system should be able to adjust the $\mathrm{pH}$ of the waste feed stream at a continuous flow rate that matches the processing rate of the rest of the system.

To ensure optimal performance from the resins, the system should be designed to accept a variety of wastes at a $\mathrm{pH}$ range of 1-13. An analysis should be performed of the system to ensure all wetted piping material is compatible with potential wastes and desired operating $\mathrm{pH}$ range.

\subsubsection{Filtration Changes}

The filtering and pumping systems should be expanded to include more capability to handle solids. The filtering system must be able to handle more solids and must be able to filter to less than $0.45 \mu$. To optimize filtering capability, the filtering system should consist of a series of two or more filtering assemblies. The filtering assemblies should have decreasing micron ratings with the last assembly in the series containing $0.45-\mu$ filters or smaller. The first filtering assembly should be designed to remove $80-90 \%$ of the solids from the waste stream. A pumping system must be added that is capable of removing the waste from the containers and also pumping thick sludges for waste consolidation and minimization.

\subsubsection{Resin Column Expansion}

To add the temporary columns to the present system, the activated carbon beds could not be operated. To treat a variety of waste solutions containing many different dissolved ions, the system should be capable of adding on resin columns without having to make extensive piping changes or without removing processing capabilities.

\subsubsection{Radioactive Resin Evaluation}

The appearance of Cs-137 in the treated solution indicates that cesium was being removed from the $\mathrm{C}-100 \mathrm{H}$ resin. An evaluation should be performed to investigate the vendor information to determine if $\mathrm{C}-100 \mathrm{H}$ resin is the best resin to use for radioactive ion removal. At present, this resin has removed radioactive isotopes from waste streams to less than DCG levels and $\mathrm{C}-100 \mathrm{H}$ has passed TCLP testing.

\subsubsection{Final pH Adjustment Changes}

Currently, the neutralization system at the discharge of the PWTU is capable of neutralizing weak acidic or caustic solutions. However, if heavy ion exchange takes place, as it did in the treatment of this waste, and lowers the $\mathrm{pH}$ of the treated solution, the system is not able to neutralize the waste for disposal. A means should be provided to neutralize this waste, either by providing a more efficient system at the discharge or by reprocessing through a $\mathrm{pH}$ adjustment system at the inlet of the PWTU. 


\subsection{PWTU Recommendation Summary}

The following changes should be made to the PWTU in order to process mixed wastes in a safe and effective manner.

\subsubsection{Permitting and Safety Documentation}

The permitting should be expanded and made as liberal as possible. The permitting should wot only include current waste hazards at the INEL, but possible future waste hazards that will be created as decontamination and decommissioning (D\&D) and site remediation functions expand at the INEL.

The safety documentation should be expanded and made as liberal as possible to include as many hazardous and radioactive wastes as possible.

\subsubsection{Larger Trailer}

The current PWTU has about $100 \mathrm{ft}^{2}$ of area. At this time there is no room for expansion. To add on the capabilities of $\mathrm{pH}$ adjustment of the feed waste and the ability to add on resin columns requires the system to be installed into a larger PWTU trailer.

\subsubsection{System Design Changes} minimum:

The system installed into the larger PWTU trailer should contain the following systems at a

- Pumping system capable of removing wastewater and sludge from 55-gal waste drums.

- $\quad \mathrm{pH}$ adjustment system capable of adjusting the $\mathrm{pH}$ of strong acidic and caustic solutions to a $\mathrm{pH}$ range of $1-13$.

- Piping system capable of handling strong acidic and caustic solutions containing $20 \%$ particulate by weight.

- $\quad$ Filtering system capable of removing a large quantity of fine particulate. The filtering system must be capable of removing particulate down to $0.45 \mu$.

- System must continue to have organic removal capabilities with activated carbon beds.

- System should continue to have three general cationic resin columns to remove radioactivity, followed by a column with resin specific for heavy metals. This should be followed by spare connections to add on columns loaded with ion specific resins for individual waste streams.

- Increased pH adjustment of the treated waste prior to final discharge from the $\mathbf{P} \quad \mathrm{U}$. This system should be able to adjust the treated waste to a pH of 6-8. 
In addition to these changes, all existing features in the PWTU not mentioned here should be kept. No functions of the trailer should be eliminated when the process is transferred to a larger trailer. 
Appendix A

PWTU Drawings 


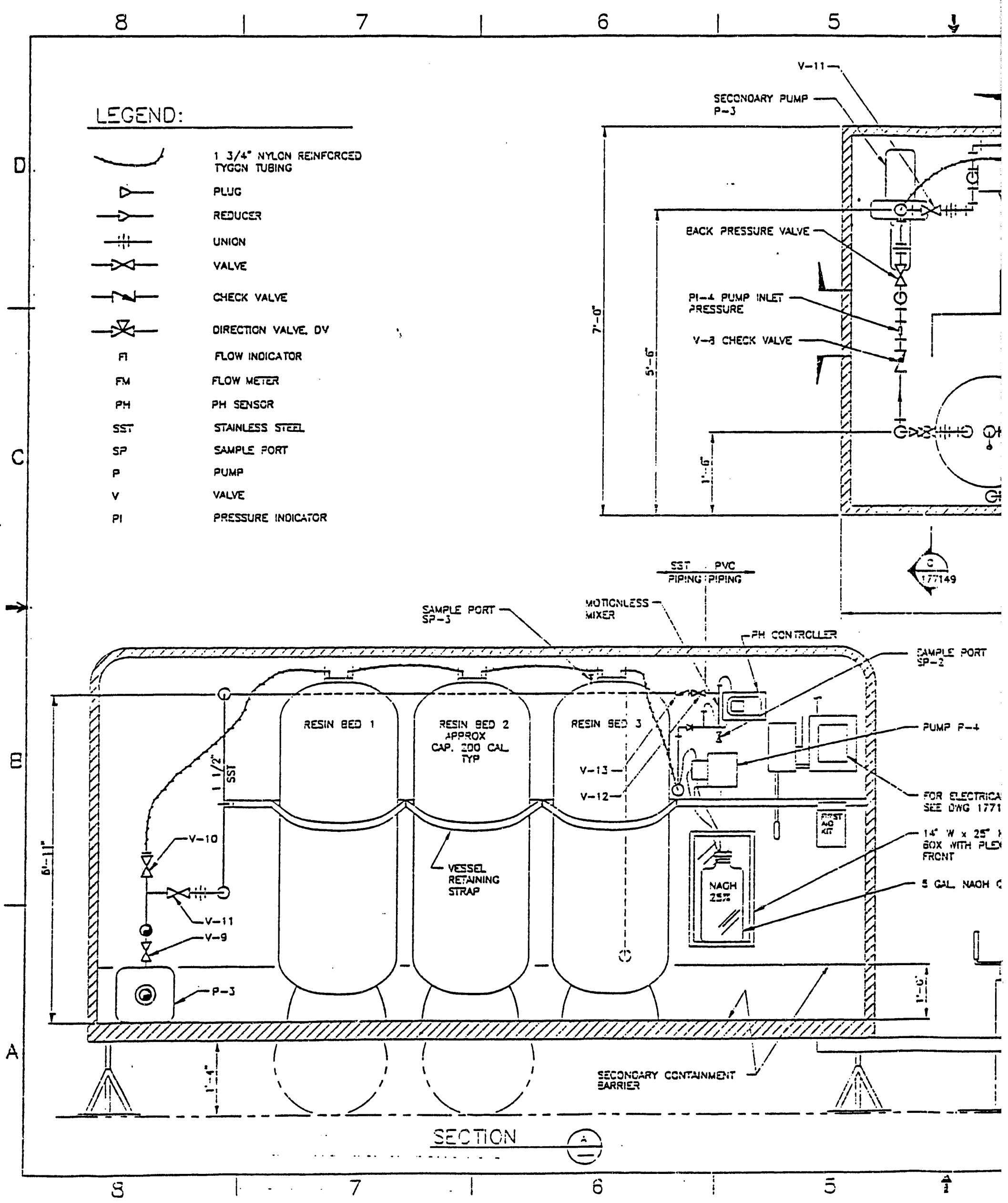




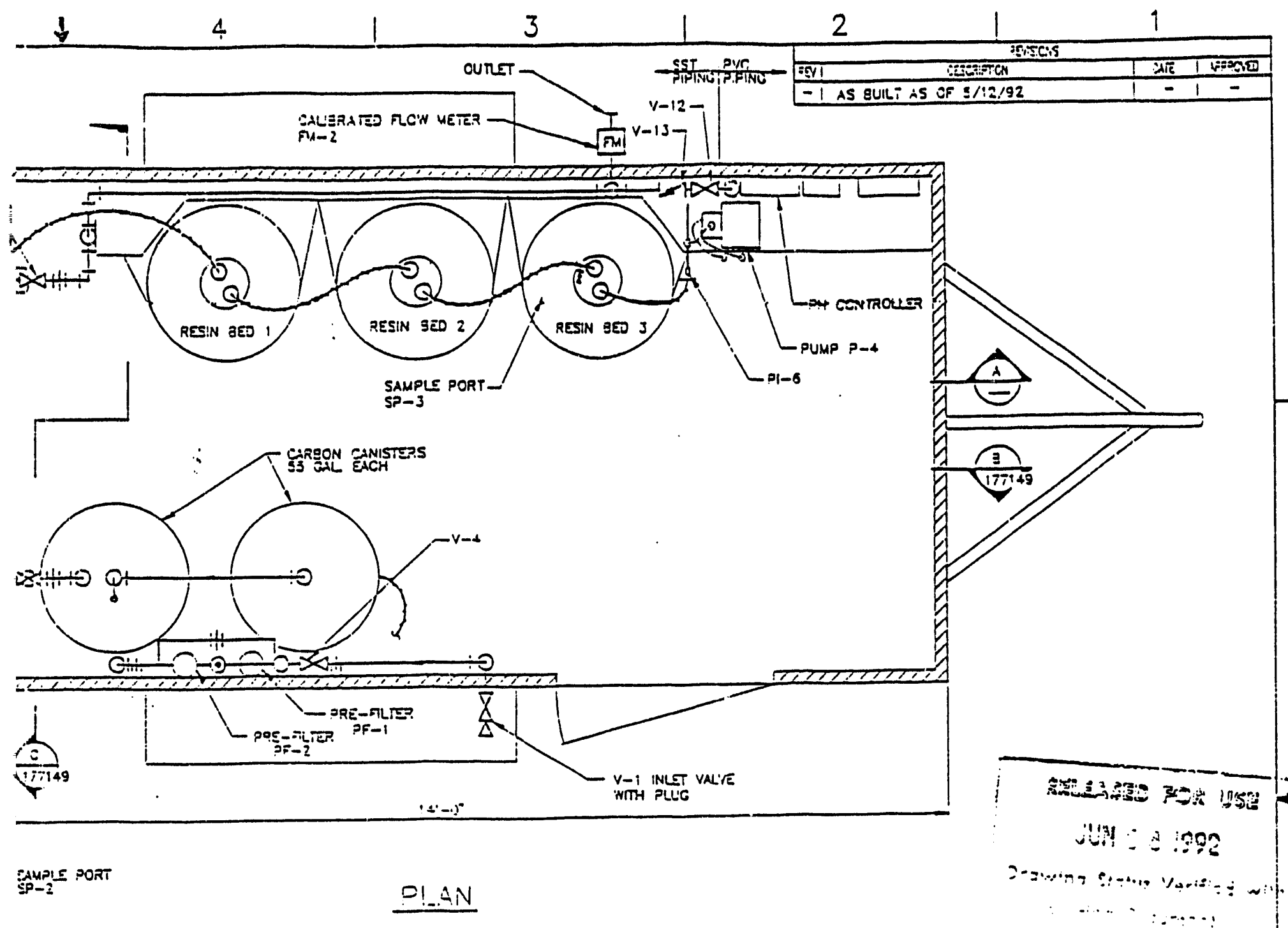

- ror g ECTRIDA: iNFORMATON SEE ONG 177150

- 14. gox vith plexiclass Frant

I EL NAOH CONTANER

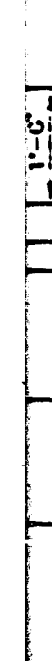

\section{NCTES:}

1. RALER SUPPUED EY OTHETS.

2 THIS ORAMNG to Ee USED IN CCNUNCTICN MTA CRAWING IT7140.

I THIS IS + CUAUT LIE 3 STSTEX. 


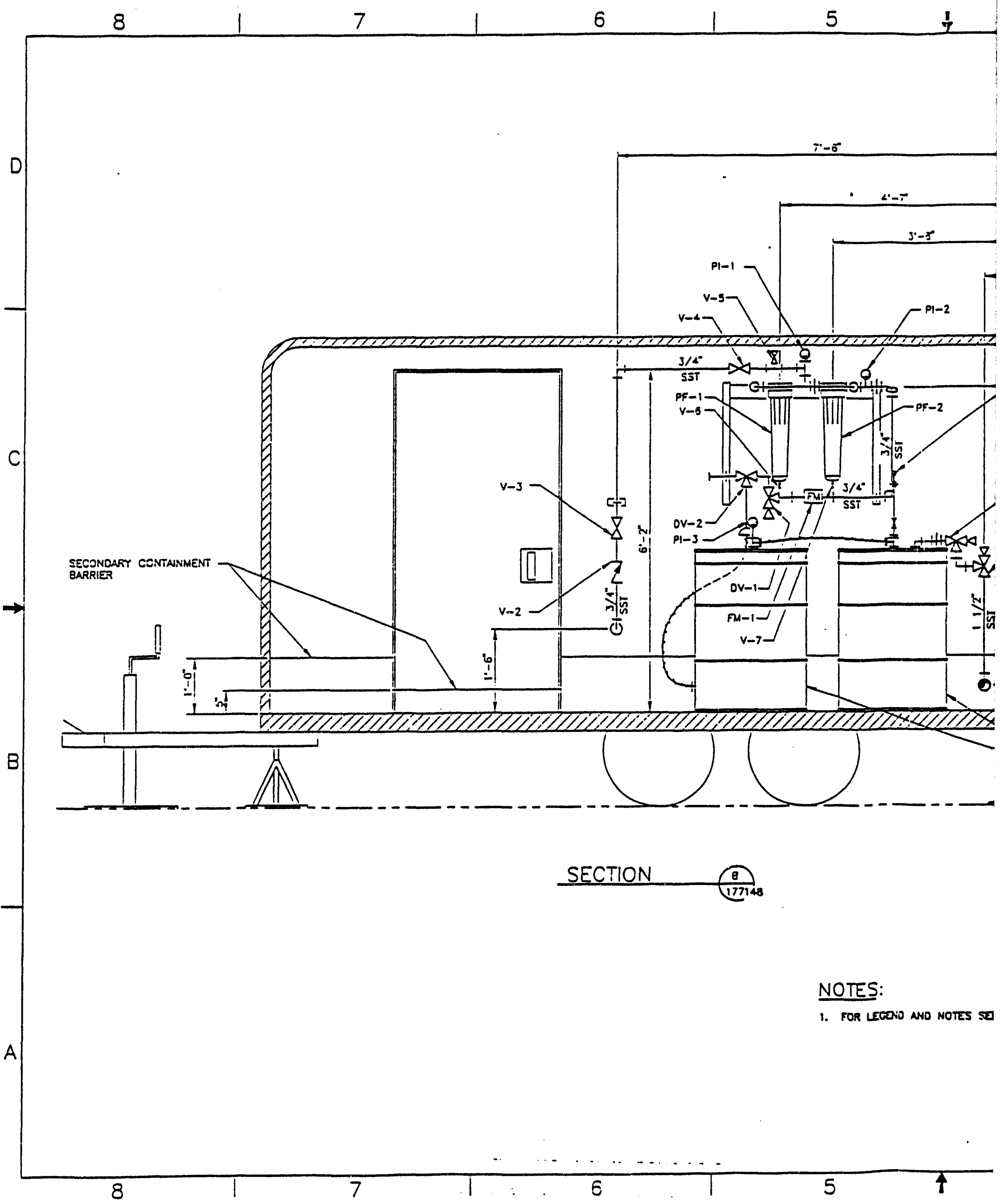



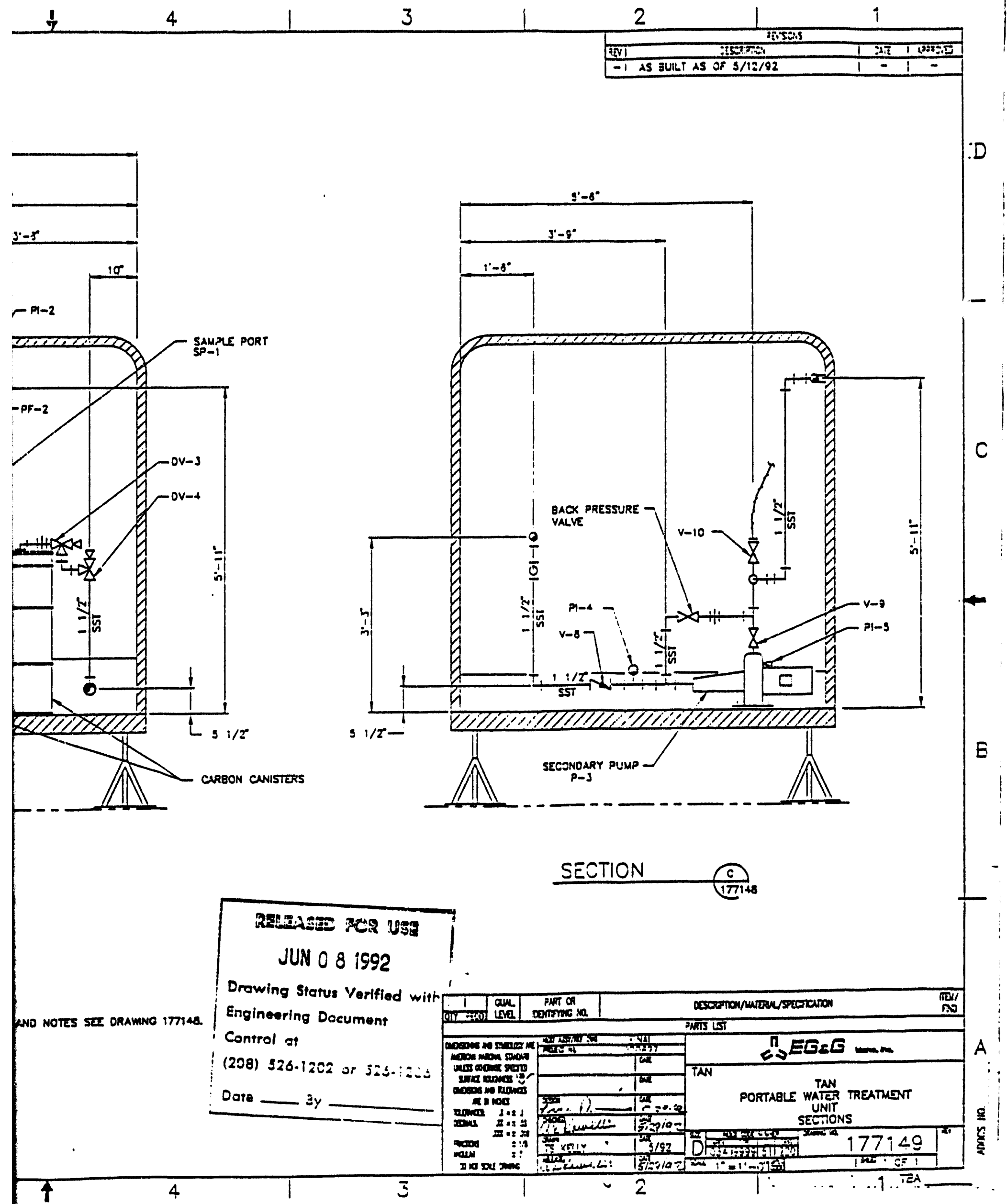

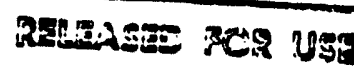
JUN 081992

Drowing Status Verified with

Engineering Document

Control at

(208) 526.1202 or $525 .: 25$

Dare _

\begin{tabular}{|c|c|c|c|}
\hline 1 and & pher of & & 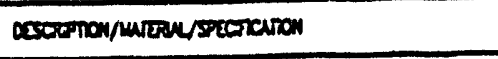 \\
\hline & & & 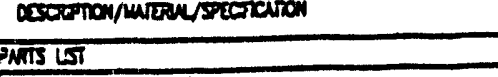 \\
\hline \multirow{6}{*}{ 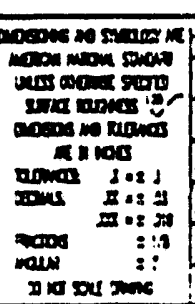 } & & & $e_{g}^{\pi} E[5 \Omega \sqrt[m]{m}$ \\
\hline & & 100 & TAN \\
\hline & 3 & Ix $=0.2$ & $\begin{array}{l}\text { PORTABLE WATR TREATMEVT } \\
\text { UNIT TIT }\end{array}$ \\
\hline & Tinvill' & Fion & SECTIONS \\
\hline & $\frac{569}{5}$ & $3 / 92$ & 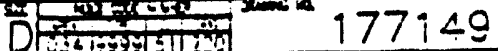 \\
\hline & An:L: & Staia? & 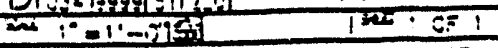 \\
\hline
\end{tabular}




\section{Appendix B}

Filtering and Decanting Procedure

B-1 
SCHED. NO. PO9PM147-A

EGEG IDAHO, INC.

FIELD CHANGE :

PLNR:

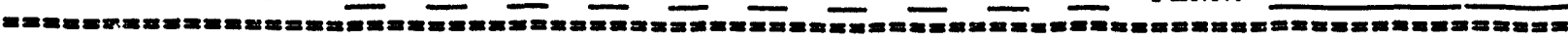
SHORT TITLE: PRETREAT WASTE FOR P.W.T.U.

CHARGE NO: 3WERT1000 उUs T $4=80$

DATE RQSTD: 07/09/92 DATE REQUIRED: 09/30/92

NEED EVENT:

AREA: TAN SUB-AREA: TSF BLDG: 607 RM: 101 EQ ID:

REQUESTOR: W.E.CLAPP

EXT: 6-6152 HOUR LIMIT: 420.0 BY WEC SWR INPUT BY: W.E.CLAPP EXT: $6-6152$

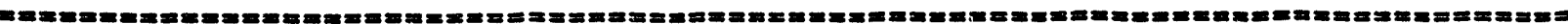
RAD-CON RVW RQD: $Y$ INITIALS:

SWP RQD: $Y$. ALARA EVAL: $N$ IH RVW RQD: $Y$ INITIALS : SSWP RQD: N RHA RQD: N TAGOUT: $\mathbf{N}$

QUAL RVW RQD: Y

INITIALS : WEC

QUAL LEVEL: B

ECL RQD: N

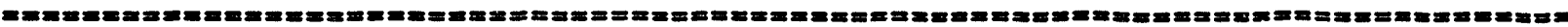
REQ MGR RVA: B.P.THIESEN QUAL RVW: A.K.PARK 08/20/92 - MATERIAL IIST INCLUDED: $Y$

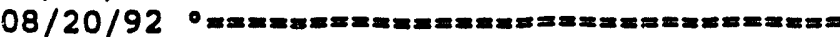

$08 / 20 / 92$

SAF RVW: R.B.EIRTH

RAD-CON RVW: D.R.LIPP

IH RVW: M.M.GARCIA

$08 / 24 / 92 \cdot$

$08 / 25 / 92 \circ$

$08 / 20 / 92$

BUD MGR RVW: B.P.THIESEN

FAC MGR RVW: K.E.STREEPER

$08 / 27 / 92$

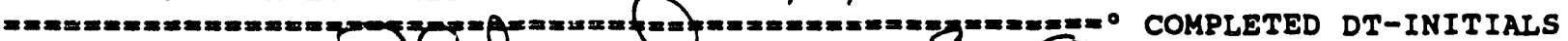
SUP'R. APPR'L. DATE: 911,92

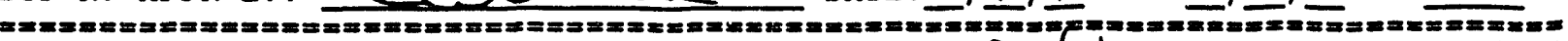
JOB-DESCRIPTION :

THIS PROCEDURE PROVIDES THE INSTRUCTIONS NECESSARY TO FILTER 35 DRUMS OF TAN RADIOACTIVE LEAD AND MERCURY CONTAMINATED SOLUTIONS. 33 DRUMS HAVE INEL WASTE ID\#123, AND 2 DRUMS HAVE INEL WASTE ID\#170. ALL THE WASTE IS CONTAINED IN PLASTIC 55 GALLON DRUMS WITH A BUNG HOLE AND A VENT OPENING. EACH DRUM CONTAINS 3-5 INCHES OF SLUDGE. THE LIQUID PORTION OF THE WASTE WILL BE DECANTED FROM THE SLUDGE, FILTERED, AND PLACED INTO CLEAN PLASTIC 55 GALLON DRUMS. THE SLUDGE WILL BE CONSOLIDATED INTO AS FEW DRUMS AS POSSIBLE. FILTERING WILL TAKE PLACE IN THE TAN HOT SHOP OR AN AREA DESIGNATED BY THE SHIFT MANAGER. SECTIONS OF THIS PROCEDURE WILL BE REPEATED FOR ALL BARRELS.

DRUMS WILL BE TRANSPORTED TO TAN WITH RESTRICTIONS ON STORAGE

LIMITS IN MIND AND WILL BE HANDLED ACCORDINGLY. STANDARD RADIOLOGICAL CONTROLS AND PRACTICES WILL BE PRACTICED AND HP SUPERVISION AND MONITORING WILL BE REQUIRED.

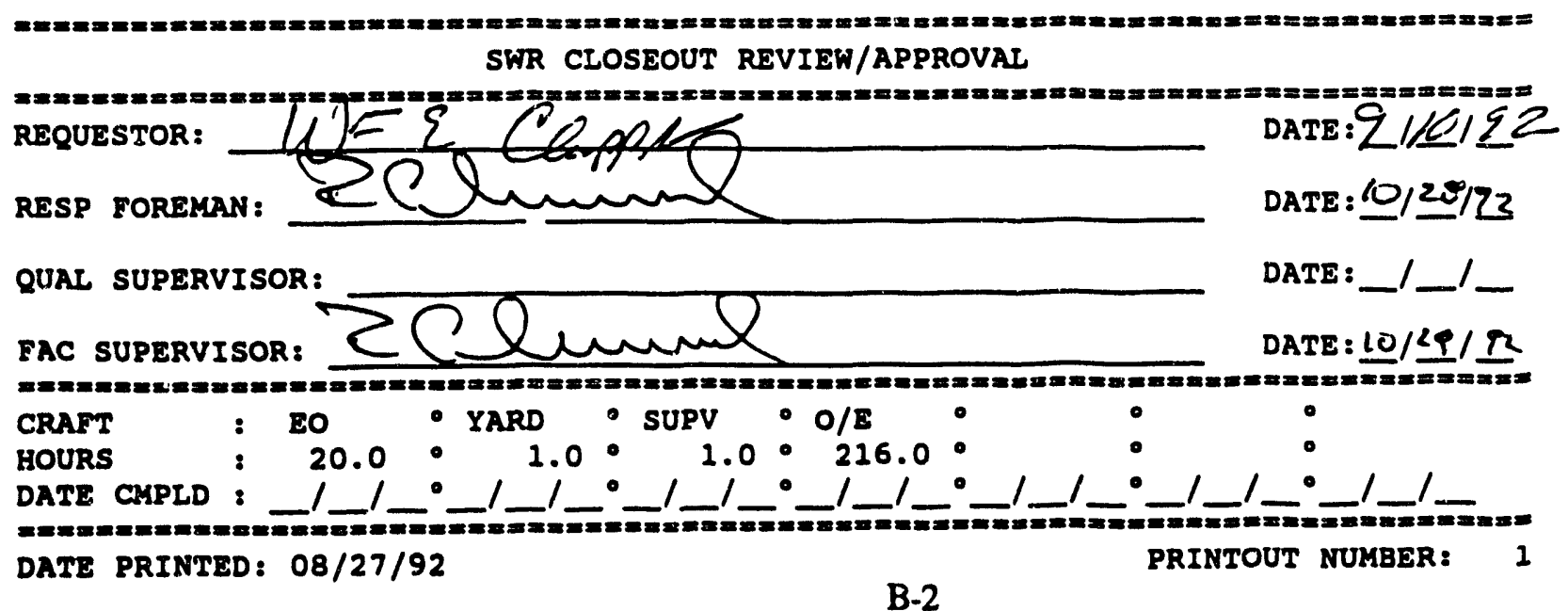


SEHE: NO. PO9PM148-A

EGEG IDAHO, INC.

SITE WORK RELEASE $92 E 08$

PAGE

2

OTHER FORMS

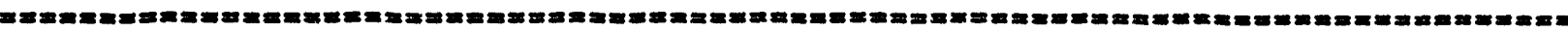
APP.A SK 1

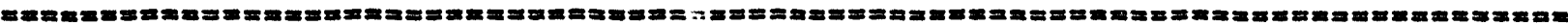


SCHED. NO. P09PMO7I

SEQ NO CRAFT

$1.500 / E$

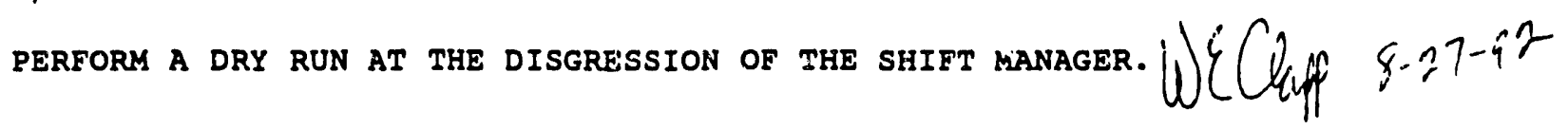

2.00 SUPV

GENERATE A SAFE WORK PERMIT AND HAVE IT PROCESSED FOR ALL WORKERS REQUIRING SUCH.

$5.000 / E$

GATHER AND STAGE THE FOLLOWING MATERIAL AND EQUIPMENT.

SAFETY EQUIP. AS SPECIFIED ON THE SWP

DISPOSABLE PAPER WIPES

DRILL AND MIXING PROPELLER

BUNG WRENCH

PH PR,PER

$10.00 \quad 0 / E$

INITIAL AND DATE: $e q, 2,92$

READ AND ACKNOWLEDGE THE SPECIFIC PRECAUTIONS CONTAINED HEREIN AND RRIEF ALI PERSONNEL WORKING ON THIS SWR.

DO NOT OPEN A FILTER HOUSING TO REMOVE A FILTER WHEN UNDER PRESSURE! THE PIC IS RESPONSIBLE TO SEE EACH STEP IS INITIALED AND DATED AS THE STEP IS COMPLETED.

THE PIC IS RESPONSIBLE FOR AUTHORIZING AND CONTROLLING ALL PERSONNEL IN CONTROLLED AREAS OF THIS WORK AND TO ENSURE SUCH PERSONNEL ARE ON THE SWP AND ARE WEARING THE APPROPRIATE PERSONAL PROTECTIVE CLOTHING.

$12.000 / E$

O/E

THE PIC WILL ENSURE ALI PERSONNEL WORKING ON THIS JOB HAVE BEEN OSHA HAZ WASTE OPERATOR AND SUPERVISOR TRAINED .

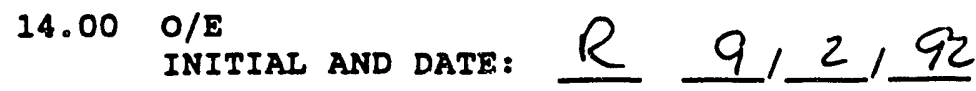

ENSURE THE HOT SHOP EXHAUST SYSTEM IS OPERATING AND IF IT SHUTS DOWN FOR SOME REASON THAT WORK IS STOPPED UNTIL THE EXHAUST IS RESTORED.

16.00 YARD

YNITIAL AND DATE: $l, 9,2,92$

SET UP A SPILL CONTAINMENT IN THE WORK AREA. 
SEQ NO CRAFT

$18.00 \mathrm{O} / \mathrm{E}$

initial and date: $\varepsilon \quad 9,2,92$

PLACE THE FILTER UNIT IN THE WORK AREA.

$20.00 \quad 0 / E$

INITIAL AND DATE:

ENTER THE NUMBER OF THE BARREL BEING FILTERED.>

ENSURE THE BARREL IS MARKED CLEARLY AND WITH A PERMANENT LABEL OR MARKING IF NOT MARK THEM AND NOTE HERE.

$20.010 / E$

INITIAL AND DATE: $\mathbb{N}$ q/2/92

VERIFY VALVES $1,2,3$, AND 4 ARE CLOSED.

$20.030 / E$

INITIAL AND DATE: 9 \& 9192

CONNECT A REGULATED AIR SUPPLY TO THE AIR INLET OF THE DIAPHRAGM PUMP. ADJUST THE REGULATOR TO 60 PLUS OR MINUS 5 PSIG.

$20.05 \quad 0 / E$

INITIAL AND DATE: W W 912,92

STAGE THE FOLLOWING EQUIPMENT AT THE WORK AREA.

PAPER WIPES

BUNG WRENCH

PH PAPER

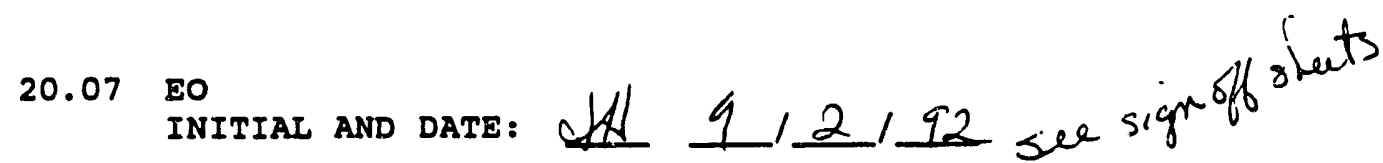
TRANSPORT DRUMS FROM THE TAA TO THE HOT SHOP.

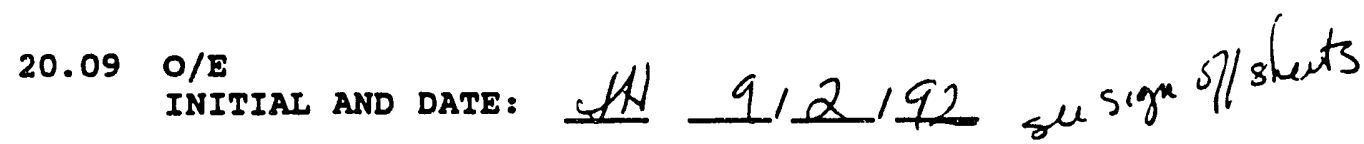

ENSURE HOT SHOP DOORS ARE CLOSED AFTER BARRELS ARE DELIVERED INTO THE HOT SHOP.

$20.110 / E$

INITIAL AND DATE: yل 912192 see sign shects

MOVE THE DRUM FROM THE HOT SHOP DOOR TO THE WORK AREA IN THE SPILI CONTAIMMENT BOUNDARY 
SEQ NO CRAFT

$20.130 / E$

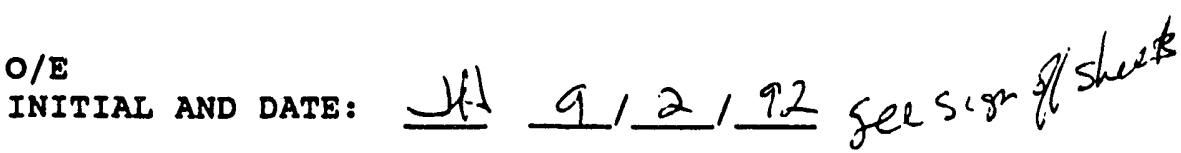

REMOVE THE LARGE BUNG FROM THE DRUM.

$20.150 / E$

INITIAL AND DATE: HJ 4/2,92

PLACE THE INLET LINE OF THE DIAPHRAGM PUMP INTO THE SOLUTION ABOUT $5 "$.

$20.170 / E$

INITIAL AND DATE: yJ $9 / 2,92$

MEASURE THE PH BY LIFTING THE LINE PARTIALLY OUT OF THE BARREL AND

SWIPING THE OUTSIDE OF THE LINE WITH A PH PAPER TO PICKUP THE RESIDUAL IIQUID.VERIFY AND RECORD THE PH HERE> PH SHOULD BE 8-9 EXCEPT FOR BARRELS 676A AND 677A WHICH WILL BE AROUND 2-3.

$20.190 / \mathrm{E}$

INITIAL AND DATE: 杖 9,2192

PLACE THE FILTER OUTLET IINE APPROXIMATELY 3 INCHES INTO THE 55 GAL. BARREL TO BE USED TO TRANSPORT THE FILTERED WASTE TO THE PWTU. SINCE ONLY 4 BARRELS PER DAY WILL BE PROCESSED THESE DRUMS WILI BE USED OVER AFTER THE FILTERED WASTE IS SENT THROUGH THE PWTU.

20.20 O/E

INItial and DATE: $\mathbb{N}$ q/2/92

OPEN VALVES 1 AND 3

$20.210 / E$

INITIAL AND DATE: $f(1) \quad 9 / 2192$

SLOWLY OPEN VALVE 4 TO START THE DIAPHRAGM PUMP. ADJUST VALVE 4 TO OBTAIN FLOW THROUGH THE FILTER CHAMBERS. INCREASE THE FLOW UNTIL THE PRESSURE DROP ACROSS THE 0.1 OR 1 MICRON FILTER IS 2-5PSID OR UNTIL THE PUMP IS AT MAXIMUM SPEED WHICH EVER OCCURS FIRST.

20.23 O/E

INItIAL AND DATE: 代 9,2192

OBSERVE THE PRESSURE GAUGES ON THE FILTERS. VERIFY THAT THE DIFFERENTIAL PRESSURE BETWEEN FILTERS DOES NOT EXCEED 40 PSID. FILTERS SHOULD BE REPLACED WHEN THE DIFEERENTIAL PRESSURE ON THE 10 AND 1 MICRON FILTERS INCREASE 20 +5-OPSI. THE . 1 MICRON FILTER SHOULD BE REPLACED WHEN THE DIFFERENTIAL PRESSURE INCREASES 5 +5-0 PSI. WHEN A FILTER NEEDS REPLACEMENT GO TO APPENDIX A. 
SEQ NO CRAFT

$20.250 / \mathrm{E}$

INITIAL AND DATE: 怙 $9 / 2,22$

OBSERVE THE FLUID IN THE DIAPHRAGM PUMP INTAKE IINE. IF AIR POCKETS APPEAR MOVE THE INTAKE LINE INTO THE WASTE LIQUID TO MAINTAIN A 5 " DEPTH. CONTINUE THIS UNTIL THE LINE STARTS TO SUCK SLUDGE. RAISE THE LINE TO APPROXIMATELY 3 INCHES ABOVE THE SLUDGE.

$20.27 \quad 0 / E$

INITIAL AND DATE: Hل $4 / 2 / 92$

WHEN ALL BUT THE LAST 2-3" OE LIQUID HAS BEEN DECANTED FROM THE DRUM STOP THE PUMP BY CLOSING VALVE 3. NOTE: DO NOT LET AIR INTO THE CHAMBERS AND DO NOT PUMP THE FILTER CHAMBERS DRY. IF THIS OCCURS THE CHAMBERS MAY HAVE TO BE VENTED TO ENSURE THEY ARE FILLED WITH LIQUID.

$20.290 / 5$

INITIAL AND DATE: Nf

Close VALVES 1 AND 3.

$20.310 / E$

INITIAL AND DATE: 状 $9 / 2 / 92$

REMOVE THE FILTER LINE FROM THE WASTE DRUM CONTAINING THE FILTERED WASTE.

$20.330 / E$

INITIAL AND DATE: O/f $9 / 2 / 92$

PLACE THE BUNGS ONTO THE WASTE DRUM CONTAINING THE FIITERED WASTE.

$20.350 / E$

INITIAI AND DATE: N $1 / 2 / 92$

WITH A MAGIC MARKER(BLACK PREFERABLY) WRITE THE DRUM \# THAT IS FOUND ON STEP 20.00 ON THE DRUM CONTAINING THE FILTERED WASTE. IF ANY OLD NUMBERS ARE ON THE BARREL WIPE THEM OFF OR CROSS THEM OUT WITH THE MAGIC MARKER.

$30.00 \quad$ O/E

INItIAL AND DATE: $41,9 / 2,92$

START SLUDGE REMOVAL. IN THIS SECTION THE SLUDGE AT THE BOTTOM OF THE CONTAINERS WILL BE CONBINED INTO 5-10 DRUMS. FILI THE DRUM WITH SLUDGE TO ABOUT $2 / 3$ FULL. IF AFTER A PERIOD OF TIME THE SLUDGE HAS SETTLED, THE LIQUID CAN BE DECANTED FOLLONING STEPS IN SECTION 20. 
SEQ NO CRAFT

$30.010 / E$

INITIAL AND DATE: $\alpha f(1)$ q/2/92

REMOVE THE TOP FROM THE SLUDGE ACCUMULATION CONTAINER. VERIFY IT IS LESS THAN $2 / 3$ FULL. PLACE THE RECYCLE IINE ABOUT 4 INCHES INTO THE SLUDGE ACCUMULATION DRUM AND TAPE INTO PLACE.

$30.03 \mathrm{O} / \mathrm{E}$

INITIAL AND DATE: 材 9/2,72

REMOVE THE BUNG FROM THE DRUM WITH THE RESIDUAL SLUDGE.

$30.050 / \mathrm{E}$

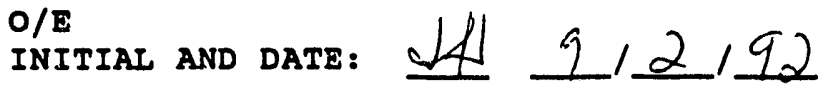

USING THE MIXING ROD ON THE DRILL, MIX THE SLUDGE TO SUSPEND IT IN SOLUTION. STOP MIXING WHEN THE SLUDGE APPEARS TO ALI BE SUSPENDED. REMOVE AND STORE MIXER FOR LATER USE.

$30.07 \quad 0 / E$

INITIAL AND DATE: HA 9/2/92

PLACE THE INLET LINE ALL THE WAY INTO THE DRUM. OPEN VALVE 2.

$30.090 / E$

INITIAL AND DATE: 4 \& $2 / 2,92$

OPEN VALVE 4 TO START THE PUMP. PUMP ALL THE SLUDGE OUT OF THE DRUM INTO THE ACCUMULATION DRUM. WHEN ALL THE SLUDGE HAS BEEN PUMPED OUT, CLOSE THE VALVE 4 TO STOP THE PUMP.

$40.00 \quad 0 / E$

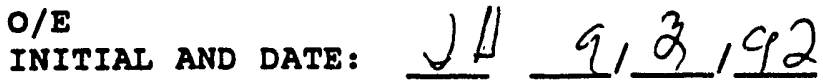

PUMP RINSE PROCEDURE. NOTE: IF THIS IS THE LAST DRUM TO BE PROCESSED FOR THE DAY CONTINUE TO THE NEXT STEP FOR RINSING. IF ANOTHER DRUM IS TO BE PROCESSED WRITE N/A IN THESE STEPS AND GO TO SECTION 50.00 .

$40.01 \mathrm{O} / \mathrm{E}$

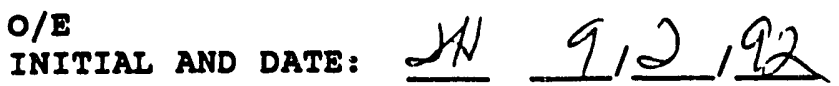

FILL A 1000ML BEAKER WITH 1000ML OF CLEAN WATER. 
SEQ NO CRAFT

$40.03 \mathrm{O} / \mathrm{E}$

INITIAL AND DATE: DN $4,2,92$

PLACE THE INLET LINE INTO THE WATER. OPEN VALVE 4 SLOWLY TO START THE PUMP. PUMP THE WATER ALL THE WAY THROUGH THE PUMP AND RECYCLE IINE AND INTO THE SLUDGE ACCUMULATION DRUM. PUMP THE LINES DRY, THEN STOP THE PUMP BY CLOSING VALVE 4.

$50.00 \quad 0 / E$

INITIAL AND DATE: 枚 9/2,92

SEAL THE WASTE DRUMS.

$50.010 / E$

INITIAL AND DATE: W $9,2,42$

VERIFY VALVES 1, 2, 3, AND 4 ARE CLOSED ON THE PUMP AND FILTERING SYSTEM.

$50.030 / E$

INITIAL AND DATE: NN 9,2,92

IF ANOTHER DRUM FOR WASTE IS GOING TO BE FILTERED, PLACE THE PUMP INLET IINE 5 INCHES INTO THE NEXT DRUM TO BE FILTERED, AND PLACE THE FILTER OUTLET LINE INTO A CLEAN DRUM. IF ANOTHER DRUM IS NOT GOING TO BE PROCESSED IMMMEDIATELY, BAG OR OTHERWISE SEAL THE INLET, OUTLET, AND RECYCLE LINES.

$50.050 / E$

inItial and date: HN 9/2/92

PLACE THE IID ON TO THE SLUDGE ACCUMULATION DRUM.

$50.07 \quad 0 / E$

INITIAL AND DATE: UN $1,2,92$

POUR 1-2 GAL. OF ABSORBENT INTO THE EMPTY WASTE DRUM.

$50.090 / 2$

INITIAI AND DATE: JN $9,2,92$

PLACE THE BUNGS IN THE EMPTY WASTE DRUMS. PREPARE THE EMPTY WASTE DRUM FOR DISPOSAL AS COMPACTIBLE WASTE. 
SCHED. NO. P09PM071

SEQ NO CRAFT

$50.110 / 8$

INITIAL AND DATE: 㑐 9,2,

PLACE THE DRUMS OF FILTERED WASTE ONTO THE SKID FOR TRANSPORT TO THE PWTU.

$50.140 / \mathrm{E}$

INItiar and date: $)$ 年

PICKUP AND STORE ALL TOOLS AND EQUIPMENT IN PREPARATION OF THE NEXT DRUM TO BE TREATED. 


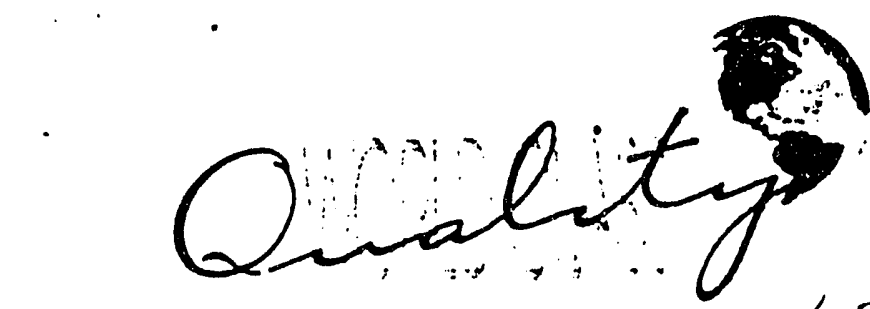

Sundar Barrel \#1 Contaixan: \# 568

$$
697
$$

569

63 ?

635

$630^{\circ}$

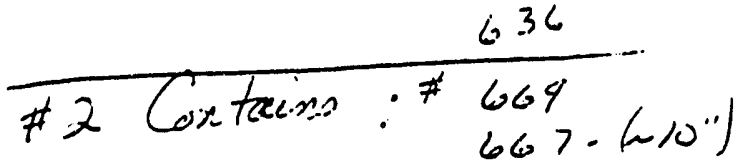

668

660

612

\#3 Contacix: * 609

610

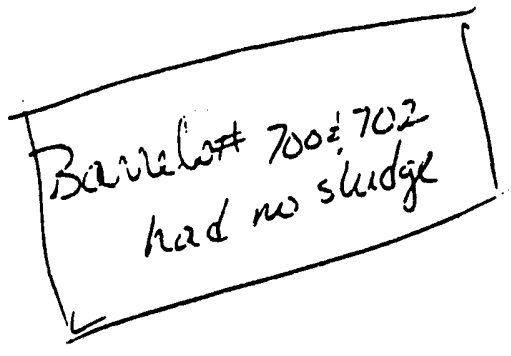

611

630

620

ㅈ?

565

701

703

$550^{\circ}$

$55 ?$

584

\#4Contacins: \# 575

590

564

572

INEL QUALITY MONTH 1991

571
576




\begin{tabular}{|c|c|c|c|c|c|c|c|c|}
\hline \multirow{2}{*}{$\begin{array}{c}\text { STEP } \\
\quad \\
\end{array}$} & \multicolumn{2}{|c|}{ BARREL *B.C. SLQ } & \multicolumn{2}{|c|}{ BARREL $\# Z \div 570$} & \multicolumn{2}{|c|}{ BARREL $\quad 8 C^{\#} 697$} & \multicolumn{2}{|c|}{ BARREI $\# 3 C \# 569$} \\
\hline & INIT & DATE & INIT & DATE & INIT & DATE & INIT & DATE \\
\hline 20.00 & Q.A & t3s & $\checkmark H$ & $\begin{array}{lllll} & 0 & 2 & 1992\end{array}$ & 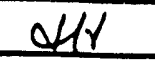 & 80031904 & $Q 4$ & SEP O 2 1992 \\
\hline 20.01 & Nex & SEP $02 \cdot 00$ & $\nu N$ & BEP O $\quad 2 \quad 992$ & $a / 1 /$ & EsP 020 & YH & SEP O D IS956 \\
\hline 20.03 & ses & SEP $02 \quad 2199$ & NH & 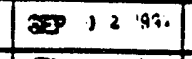 & Wr & $50 \mathrm{Ca}$ & N & SEP 0 : $=0$ \\
\hline 20.05 & ell & SEP 022 F9: & $N N$ & |iss & $\mathbb{N}$ & (50.250 & $d y$ & IEP :: :0:: \\
\hline 20.07 & Nhl & SEP O 2 lac & (th & Exp 0: & $W$ & SEP $\cap 2$ : $: 998$ & $\mathrm{dH}$ & SEP $022 \mathrm{OMn}$ \\
\hline 20.09 & 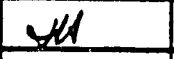 & 3EP : 2 120: & sh & SEP 023 1992 & $\mathrm{Hed}$ & 다 $1:$ : & W & EP. 52.922 \\
\hline 20.11 & oth & SEP 021992 & $1 N$ & 0021932 & $d$ & 0021902 & $\Psi N$ & $\operatorname{sep} C: 2 \times 9$ \\
\hline 20.13 & 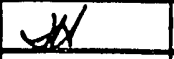 & 3EP 021992 & $\mathcal{H}$ & 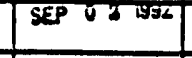 & UN & DP 02 1992 & $J N$ & 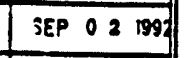 \\
\hline 20.15 & $\forall t$ & GEP 0221992 & oth & $\operatorname{ses} 68$ & 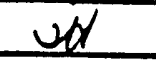 & $000: 0: 5 \div$ & $U N$ & SEP $\begin{array}{llll}0 & 2 & 1992\end{array}$ \\
\hline 20.17 & $W$ & SEP J 21992 & 24 & $\operatorname{tat} 0::=-1$ & $N$ & STS 0 a sines & $y$ & SEP i 2 iț \\
\hline pH & $P H$ & -11 (clear) & $\mathrm{PH}-$ & - 9 (clear) & $P . H$. & - I/(clear) & P.H - & - 8(elear) \\
\hline 20.19 & $\alpha H$ & SEP 021992 & at/ & SER: & EN & $\begin{array}{lllll}0 & 0 & 2 & 1994\end{array}$ & HN & des 6 \\
\hline 20.20 & 2 & SEP 021992 & $N$ & SEP 02 M922 & $\mathcal{H}$ & 80031992 & JN & $x C_{2}$ \\
\hline 20.21 & 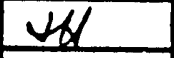 & $\mathrm{SE}^{2}: 2$ & 4 & SEP $022 \mathrm{men}$ & $\mathrm{kN}$ & 52030.1992 & th & $i 2 ?$ \\
\hline 20.23 & $\mathrm{IN}$ & $\cdots=0$ & $N$ & $800^{2}-100$ & $\alpha$ Al & $\cos 0250$ & 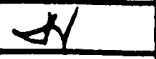 & ses 021992 \\
\hline 20.25 & कH & (ש5 021992 & NH & $\operatorname{ses} 5235$ & at & 003 & $\alpha$ & EEP 0 O :992 \\
\hline 20.27 & $\Delta N$ & PEP 021992 & ok & SEP 022 T3: & ky & 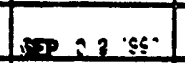 & Wh & SEP $0:$ : : : \\
\hline 20.29 & $\alpha H$ & $0202 \quad 021994$ & WN & $30,12 \pi$ & $\Delta N$ & 8000300 & atN & SEP : \\
\hline 20.31 & 211 & sed 02 1992 & $\Delta N$ & $8002 \mathrm{man}$ & ath & SEP O 21502 & SH & 180 \\
\hline 20.33 & $\Delta N$ & SED & aty & SEP 02 SO2 & $N$ & 80020 & $d X$ & SEP $022 \mathrm{~m}$ \\
\hline 20.35 & at & $\cos 02 m_{i}^{\prime}$ & $\mathcal{N}$ & 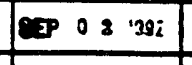 & $d x$ & 8002004 & कx & SEP O 02 1992 \\
\hline 30.00 & 24 & 04031992 & $d t$ & SEP 03 ise & All & SEP 021592 & oth & 200 \\
\hline 30.01 & 4t & SEPP 031 & $1 N$ & SEP $02 \quad 21992$ & Nt/ & SEP O 2 1992 & $\Delta$ & 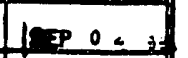 \\
\hline 30.03 & जी & jEP 028 & $N$ & Sep , 12 : 492 & +4 & SEP 020 14j: & $W$ & 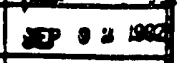 \\
\hline 30.05 & 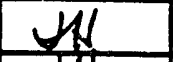 & SEP 025 & 4 & $=212 \mathrm{~km}$ & oxk & SEP 020 & $d x$ & ecp 02001 \\
\hline 30.07 & $\checkmark N$ & $02 \mathrm{x}$ & $\mathrm{W}$ & Eer 0200 & akl & $\operatorname{xec} 02 \mathrm{san}$ & 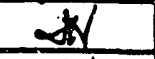 & SEP $02 \mathrm{a}$ \\
\hline 30.09 & otN & SEP 4 \& $\&$ X & $\Delta$ & 8EP 023202 & $2+1$ & $\operatorname{IxP} 02$ & $\alpha+k$ & 258022 \\
\hline 40.00 & $N / 4$ & $\sqrt{1242}$ & $\Delta / A$ & $\sqrt{12 \sqrt{2+2}}$ & $N / A$ & $\sqrt{9+10}$ & $N / A^{M}$ & SEP - 15 \\
\hline 40.01 & $N / A \quad H$ & $\sqrt{a^{2}+\infty}$ & $N / S$ & $\sqrt{4 \sqrt{2}}$ & $N / A$ & $\sqrt{1.210}$ & $N / A^{2}$ & SEP 0 C בני \\
\hline 40.03 & $N / A$ & $T \pi n$ & NIA & artar & $N / A$ & $\sqrt{1.620}$ & NLA & EtP 0 a is a \\
\hline 50.00 & $\mid \mathrm{H}$ & EEP 02 (1992 & atd & SEP O 23 & 4 & Sesp 0.100 & 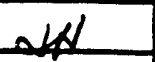 & Yup $02 \mathrm{~m}$ \\
\hline 50.01 & $\alpha A$ & SEP $02 \mathrm{~cm}$ & tw & $\operatorname{ses} 0$ as 0 & 14 & E.5P & otel & $3 E=, 3 \mathrm{~m}$ \\
\hline 50.03 & ato & $\sec 02021002$ & 14 & 500202 & $W$ & esp : . & QS & $20022 \%$ \\
\hline 50.05 & $N / A \cup \gamma$ & 500.2 1953 & $\mathbb{N}(A+\alpha)$ & 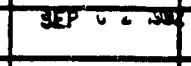 & Nlaw & $\exp 6$ & $N / A+4$ & $\sec 122^{\prime \prime}$ \\
\hline 50.07 & $N$ & SEP 02209 & 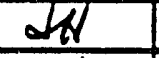 & SFF ${ }^{\prime}=$ ied & H4 & 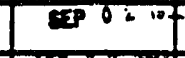 & W & $\operatorname{Ex} 0: \ldots$ \\
\hline 50.09 & H H & CEP 021009 & a & exp $1 \ldots$. yyaz & 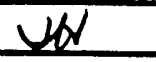 & set $027 \mathrm{ses}$ & 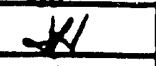 & $\sec 02$ \\
\hline 50.11 & $W$ & $022150 \mathrm{~d}$ & ats & 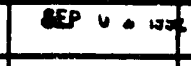 & H & 202 & 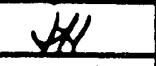 & 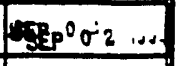 \\
\hline 50.14 & ofts & $9-2+2$ & thl & $9-2-22$ & $M$ & $9-2-42$ & QAN & $9-2-92$ \\
\hline
\end{tabular}

Bar code numbers are the lact three rumbers in the code $92-92$ * 40.00-40.03 N/A'ed then st tas we will be continuing with neme water removal war 9-2-92

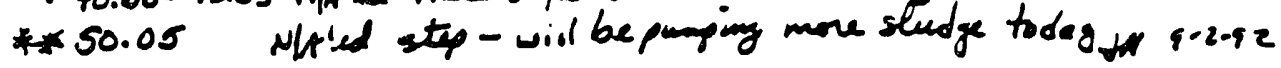




\begin{tabular}{|c|c|c|c|c|c|c|c|c|}
\hline \multirow{2}{*}{$\begin{array}{c}\text { STEP } \\
\ldots\end{array}$} & \multicolumn{2}{|c|}{ BARREL $\quad$ BC. $\$ 637$} & \multicolumn{2}{|c|}{ BARREL $\# Z * 635$} & \multicolumn{2}{|c|}{ BARREL 12.6 .638} & \multicolumn{2}{|c|}{ BARREL $\quad 8 . C \% 36$} \\
\hline & INIT & DATE & INIT & DAT & INIT & DATE & INIT & DATE \\
\hline 20.00 & $W$ & 202021944 & H & & ot & 00200 & 4 & 0 \\
\hline 20.01 & WH & 13021092 & +4 & 99 & NW & ERP $02 \mathrm{~mm}$ & 4 & P 0 \\
\hline 20.03 & 14 & 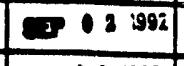 & wh & Sep o. 56 & Hel & $\operatorname{sep} 02 \mathrm{~cm}$ & $W$ & SEP 0 \\
\hline 20.05 & ath & \begin{tabular}{|llll} 
Sap & 0 & 2 & 992 \\
\end{tabular} & NH & $3 E P \quad 1 / 40$ & ond & $0002 \mathrm{~mm}$ & W & LPP 0 \\
\hline 20.07 & H & SEP $\quad 11 \mathrm{~m}$ & HN & SEP $02 \mathrm{mPO}$ & ast & SEP $02 \quad$ M & WN & SEP 0 \\
\hline 20.09 & $\mathrm{Wl}$ & $\operatorname{sep} 021992$ & sh & SEP 02 lon & HN & $\operatorname{stp} 021900$ & EN & 3EP 02 \\
\hline 20.11 & WN & 3028 is: & NH & sep :12:06: & $\checkmark N$ & SEP $02 \mathrm{~mm}$ & III & 0 \\
\hline 20.13 & W & 032.21 & 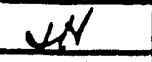 & XPP: : & $a t N$ & SEP 02280 & & SEP O2 \\
\hline 20.15 & LN & EP : & SH & SEP $02 \mathrm{men}$ & tN & SEP $02 \mathrm{~m}$ & H. & \\
\hline \multirow{2}{*}{$\begin{array}{l}20.17 \\
\mathrm{pH}\end{array}$} & $d A$ & $3913 \times$ & $\mathrm{H}$ & SEP O a $\mathrm{m}$ & $g(x)$ & 800038 & $1 x$ & \\
\hline & \multicolumn{2}{|c|}{ P.H. -9 (clar) } & \multicolumn{2}{|c|}{ P.H. - J(clear) } & \multicolumn{2}{|c|}{$P . H .-7(\mathrm{clear})$} & \multicolumn{2}{|c|}{$P_{1} H .-9(c l e a r)$} \\
\hline 20.19 & $2+1$ & SEP 023 ma2 & 24 & SEP : $2 \mathrm{Nm}$ & $\checkmark n$ & $\operatorname{sep} 0285$ & $\mathbb{N}$ & $\operatorname{Ex} 02199$ \\
\hline 20.20 & $2 H$ & 03021992 & t4 & $\operatorname{sep} 02 \mathrm{~mm}$ & aty & sEP 021992 & $\mathrm{HW}$ & SEP O \\
\hline 20.21 & $\Delta+4$ & 02021954 & sty & & $\alpha$ & $\begin{array}{lllllllll}3 E & 0 & 2 & 2\end{array}$ & +41 & exp \\
\hline 20.23 & ate & 002994 & 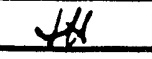 & $m$ & 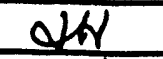 & xp $02 \mathrm{~m}$ & W & \\
\hline 20. & $\alpha W$ & espers 0 : aso & $\$ 4$ & 29 & $H$ & $021 .$. & NN & \\
\hline 20.27 & oth & $\cos 02 \mathrm{sm}$ & L4 & $m$ & sth & $\mathrm{OP} 02 \mathrm{kmen}$ & ed & \\
\hline 20.29 & $\alpha N$ & 20031002 & $W N$ & $m$ & $N N$ & sep 02 1992 & & top \\
\hline 20.31 & $\Delta X$ & $\exp 0.1$ & W & 0.200 & ath & 2000 & & $\infty 120$ \\
\hline 20.33 & an & 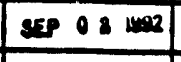 & 4 & SEP $02 \mathrm{k00}$ & $\sqrt{A N}$ & الثق3 & WN & ison \\
\hline 20.35 & $\perp A$ & 2020000 & HI & & 161 & $\cos 12:=2$ & $d t$ & 0020 \\
\hline 30.00 & 40 & $\operatorname{ces} 0$ : & otN & gtP 03 & 4 & SEP O 31002 & $\mathscr{N}$ & SEP 0,299 \\
\hline 30 & st & 3EP OO 1958 & $\Delta N^{H}$ & \begin{tabular}{|lllll} 
SEP & 0 & 3 & $: 928$ \\
\end{tabular} & HA & SEP O 31902 & HI & 3EP \\
\hline 30 & WH & 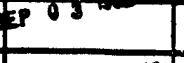 & $\sqrt{4}$ & BEP :13:502 & $+N$ & $8000,95:$ & $W$ & w \\
\hline 30.05 & W & Sesp 0.81952 & $\mathrm{H}$ & sep 0 o say & $2 x$ & mog & 46 & $\cos 0100$ \\
\hline 3 & 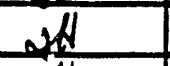 & SEP O 31908 & $\alpha+N$ & SEP 0 . 552 & $\mathrm{kn}^{2}$ & कबस & $\sqrt{6}$ & Exp O O 197 \\
\hline 30.09 & in & ifP D D $_{3}$ : 552 & Y4 & 8003 1094 & 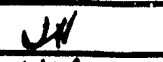 & 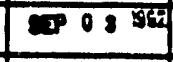 & 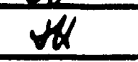 & 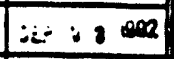 \\
\hline 40.00 & N/A & $1-\frac{1.84^{*}}{2}$ & NA 2 & $\sqrt{122}$ & $N \mathrm{~N}$ & 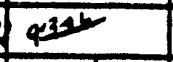 & $-\left(\left.\right|_{1} ^{\prime}\right.$ & $\operatorname{sep} 0281092$ \\
\hline 40.0 & $N \mid A-H$ & 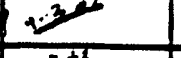 & $\mu \mid A$ & las & N/A & w21 & $+d$ & SEP 021992 \\
\hline 40.03 & N/A.2M & "20 & MA & 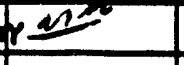 & D.4 & 4 & $\downarrow N$ & 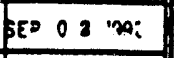 \\
\hline 50.00 & HA WN & \begin{tabular}{|c|c|c|}
20 \\
\end{tabular} & st & 4 E. 08 & 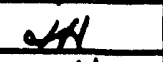 & $\cos 0200$ & $\$ N$ & 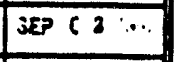 \\
\hline 50.01 & oth & 20202 & kt & OEP 021992 & WH & 20028 & 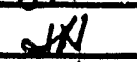 & 8002 (505) \\
\hline 50.03 & sies at & $\Gamma_{2}$ & d4 & 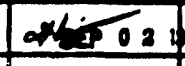 & & $\sqrt{+\infty x_{2}}$ & ste & EEP O 2 \& \\
\hline 50.05 & N/A IN & - & $N / A$ & $=$ & $N / 4$ & - & axy & 205021002 \\
\hline 50.07 & $w$ & sap $0.2 \mathrm{mat}$ & Sis & 2ep 031992 & $d H$ & & $\mathbb{N}$ & cPp 035 \\
\hline 50.09 & d! & SEP 0,289 & $d / 1$ & $\operatorname{sep} 0: 992$ & $d x$ & SEP 039 & est & $\left.\overline{5} ?^{2}\right]$ \\
\hline 50.11 & $2 \mathbb{N}$ & 830,0992 & N. & $500 \cdot \cdots$ & IX & SEP 035 & 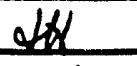 & 52035 \\
\hline 50.14 & L & $9-392$ & W & $9-3+2$ & KI & $9-3-12$ & HA & 12 \\
\hline
\end{tabular}

Bare Code numbers are the lact three numbers in the code 1 r-2-12

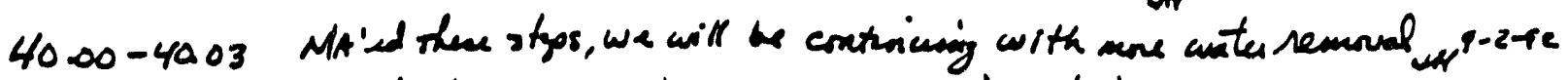

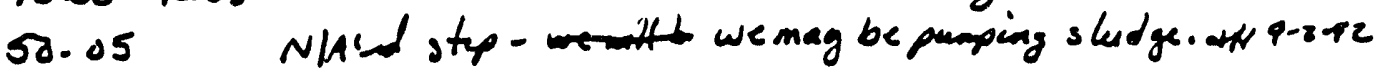

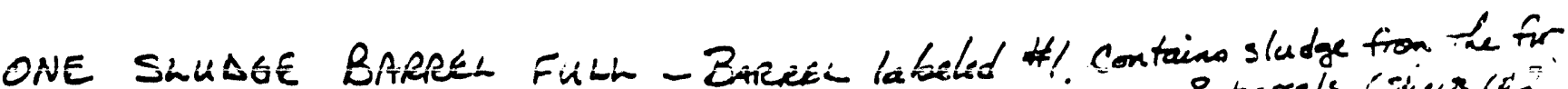
8 barrels cineus $6 t^{\circ}$ 


\begin{tabular}{|c|c|c|c|c|c|c|c|c|c|}
\hline \multirow{2}{*}{ STEP } & \multicolumn{2}{|c|}{ BARREL 13. ' 669} & \multicolumn{2}{|c|}{ BARREL $: 86.667$} & \multicolumn{4}{|c|}{ BARREL $136^{*} / 68$ BARREL $3 C^{7} 666$} & \multirow[t]{2}{*}{ 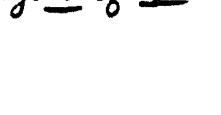 } \\
\hline & INIT & DATE & INIT & DATE & INIT & DATE & INIT & DATE & \\
\hline 20.00 & $\$ 4$ & SEP I 31992 & $\Delta N$ & SEP O 31902 & dt & 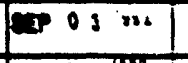 & oty & SEP O 3 & \\
\hline 20.01 & LN & SEP 0 I 1992 & $W$ & SEP 03 isnd & Wh & 3 & 4 & SEP 03 & \\
\hline 20.03 & wh & SEP S SM & H & $2 x^{2}: 3$ ing & सh & EP 03.392 & He & gEP : 3 & \\
\hline 20.05 & $2+4$ & SEP 031992 & 虹 & sti $\quad:=$ & ath & & 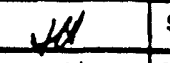 & SEP $0_{3}$ & - \\
\hline 20.07 & SH & sep o $3: 90$ & 出 & \begin{tabular}{|lll} 
SEP 0 & 0 & 3 \\
\end{tabular} & H & & th & SEP O 3 & \\
\hline 20.09 & KL & SEP O 3 : 992 & $H$ & SE? & $\alpha$ & SEP O $3 \quad{ }^{1992}$ & X|X & SEP : , & \\
\hline 20.11 & H & $: 50 \quad: 3 y_{j i}$ & $d N$ & 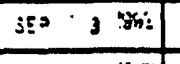 & ath & ERP 03 ligy2 & $\alpha$ & SEP 031 & - \\
\hline 20.13 & $N$ & $x+23$ & $\mathbb{W}$ & 4 & $\alpha$ & $\begin{array}{llllll}\text { SEFP } & 0 & 3\end{array}$ & $H$ & SEP O 03 : $3:$ & \\
\hline 20.15 & $\mathrm{at}$ & SEP O 3 is:2 & $\mathbb{N}$ & 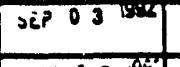 & th. & & 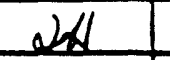 & SEP $>3 \quad 39$ & \\
\hline \multirow{2}{*}{$\begin{array}{l}20.17 \\
\mathrm{pH}\end{array}$} & $2 \mathrm{~W}$ & SEP : : & $\downarrow H$ & उEP C 3 S4: & WV & गet d o d & (t) & SEP 00 , 14 & \\
\hline & PH. & -10 lelor) & \multicolumn{2}{|l|}{ P.H. } & P.H. & $-1 \alpha_{(6 a r)}$ & \multicolumn{2}{|c|}{$P . H .-1 Q_{\text {eler }}$} & \\
\hline 20.19 & 24 & 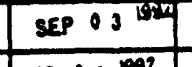 & 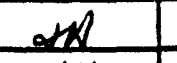 & JEP : & 奖 & SEP O \& 1992 & $\sqrt{N}$ & SEP O O 1992 & \\
\hline 20.20 & $a|d|$ & $-E^{2} \div 3$ & Wh & 다 : : & H & 3EP O 031992 & H & EEP O I 1992 & \\
\hline 20.21 & $W$ & SED : : 94 & 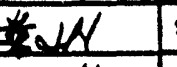 & SEP O 31992 & +4 & are $0,16$. & $\mathrm{NW}$ & SEP 03199 & \\
\hline 20.23 & 24 & EPP $:: \mathrm{rm}$ & K & 3EP O 3 1902 & $x$ & SEP 031992 & $W$ & sep 0,195 & \\
\hline 20.25 & des & S5P Q 21092 & $\alpha$ aN & SEP 03 S & (2) & SEP O 3 iss. & $k$ & SEP O O 1992 & \\
\hline 20.27 & $|x|$ & SEP 0,3 'ys & tet & exp 0031992 & $\alpha$ & 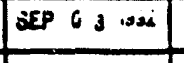 & KI & SEP O 3195 & - \\
\hline 20.29 & $N$ & 3EP : : & $a$ & sep o 3 & म & SEP O, & Wh & SEP 0, 10 & \\
\hline 20.31 & ty & SEP O I 1992 & $\mu$ & SEP O 03 1992 & का & SEP 0 \& 992 & \pm 4 & SEP 031989 & \\
\hline 20.33 & $H$ & 3EP J I 992 & N & 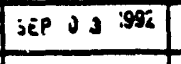 & 40 & 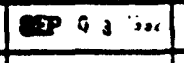 & $d N$ & $35.3,3990$ & \\
\hline 20.35 & $H$ & desp oy .0. & 26 & SEP OO O $: 3 \mathrm{Bi}$ & 36 & 0000.00 & ats & $\operatorname{sep} 0:=0$. & \\
\hline 30.00 & An & SEP O \& 1902 & N N & SEP O 01992 & ofth & SEP 0 , 1802 & $\alpha$ & SEP 0031952 & \\
\hline 30.01 & atd & SEP 03 is: & $\Delta$ & SEP O I 1992 & eld & esp 0? & atN & SEP 033 isth & \\
\hline 30.03 & fN & SEP : ? 392 & 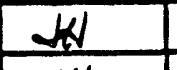 & 3EP O O 3 : $15: 4$ & עd & SEP O: 1992 & W & $\operatorname{SEP} G_{3}{ }^{\circ}$ & \\
\hline 30.05 & DN & SEP O I 1002 & $\Delta$ & $0,0,192$ & v14 & SEP OO Lex & 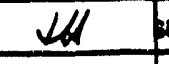 & EEP 0.800 & \\
\hline 30.07 & $\mathbb{N}$ & SEP 03 'yjo & 2 & $\operatorname{ser} 021992$ & UN & SEP O I S & $\Delta N$ & 803001932 & \\
\hline 30.09 & $\mathbb{N}$ & SEP G \& & $\forall 1$ & SEP O I LFAR & 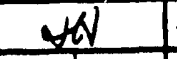 & 3EP 0,2 Las: & 4 & axs 003 & \\
\hline 40.00 & $N A$ & $9.2 \pi$ & Nh ald & $8^{23}$ & 194 & $4^{n-12}$ & D) 4 & $r^{3+i}$ & \\
\hline 40.01 & N/A DH & $r^{4}$ & NIA & $42 \sqrt{2}$ & MA N & $13^{2}$ & N/4 & $1 . .3 .5$ & \\
\hline 40.03 & $N / A$ & $e^{2+2}$ & N/l +4 & क्षक & N/ & $\sqrt{250}$ & Nkt & $\sqrt{1+20}$ & \\
\hline 50.00 & $\pm N$ & $\operatorname{sEs} d_{3} \operatorname{sen}$ & 4 & loges & aW & SEP O O I & WN & ser of 1992 & \\
\hline 50.01 & $\mathrm{H}$ & SEP O O 1992 & itl & SEP O 31992 & $-\alpha$ & SEP $0_{3}$ issi & tex & ses 0,2154 & Africe 12 bure \\
\hline 50.03 & $H$ & $\operatorname{ses} 0: 0.0$ & a/l & $\operatorname{sep} 0_{3} \ldots$ & $\mathbb{N}$ & etP 031900 & $\$$ & axp 02 & \\
\hline 50.05 & NA $x_{1}$ & $\sqrt{5 x}$ & NA N & $\overline{x_{12}}$ & $\nu / a+a$ & $y+2$ & NAS +f & $\sqrt{r-3+e}$ & j \\
\hline 50.07 & s & sesp O 1992 & $a+k$ & 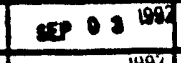 & $\operatorname{sech} 1902$ & SEP 021002 & dA & 502020 & \\
\hline 50.09 & W & SEP O 31992 & $\alpha N$ & sep 0 o 1996 & $\cos 150$ & $\operatorname{sep} 03$ is92 & $J$ & $\operatorname{ses} \theta$ & CHAWEES \\
\hline 50.11 & W & 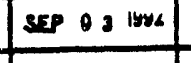 & W & SEP 031998 & see 1992 & SEP 0021502 & $4 x$ & exp 03 lay & on Pump \\
\hline 50.14 & $\alpha W$ & $9-3+2$ & $\mathrm{LN}$ & $9-3-12$ & 24 & $43-52$ & dN & $9-3-52$ & \\
\hline
\end{tabular}

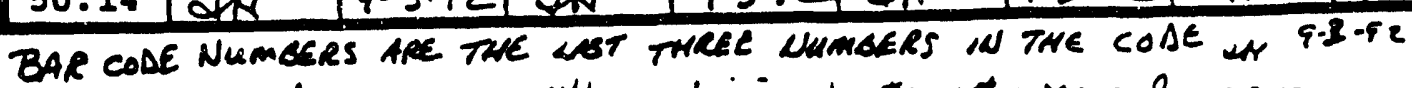

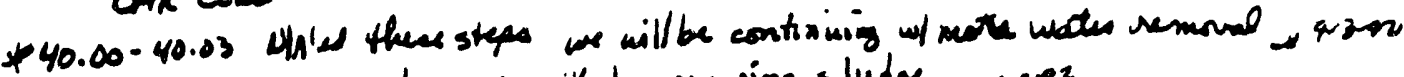

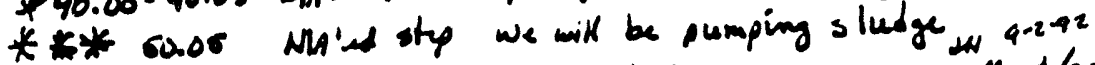

* Burel \#667 (8to 10" of sludg) Heawier sludge. Most becrele had 2.3 "If sludge

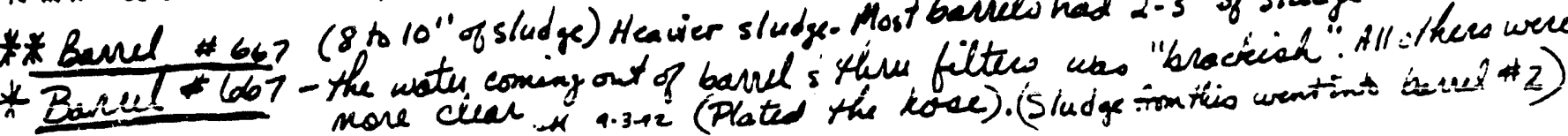




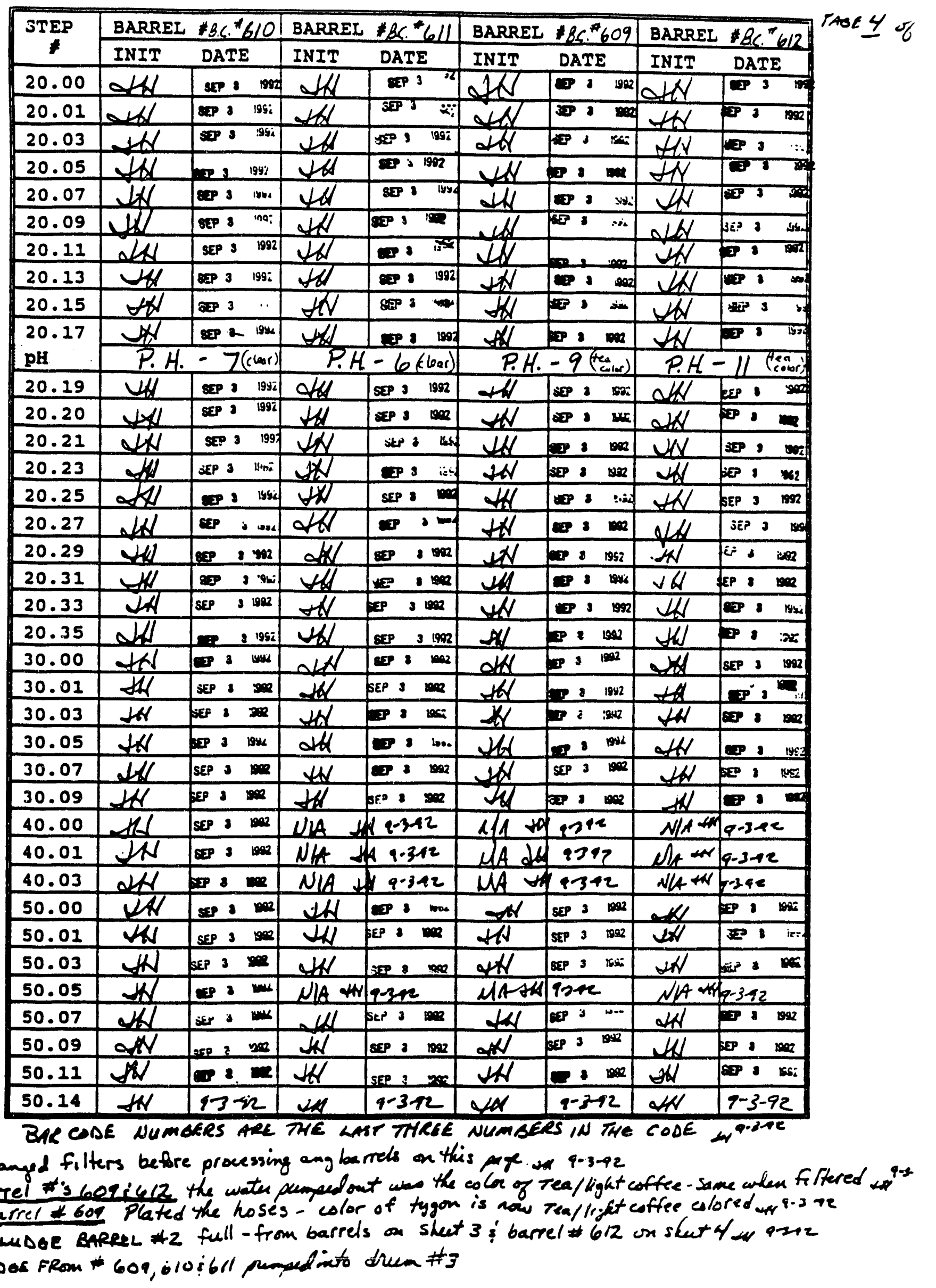




\begin{tabular}{|c|c|c|c|c|c|c|c|c|}
\hline \multirow{2}{*}{$\begin{array}{c}\text { STEP } \\
f\end{array}$} & \multicolumn{2}{|c|}{ BARREL $\quad B C * 630$} & \multicolumn{2}{|c|}{ BARREL $186 \$ 627$} & \multicolumn{2}{|c|}{ BARREL $\$ B c^{*} 626$} & \multicolumn{2}{|c|}{ BARREI 565} \\
\hline & INIT & DATE & INIT & DATE & INIT & DATE & INIT & DATE \\
\hline 20.00 & tal & $3:: 902$ & stet & 8. 1992 & $t \mid$ & $=2$ & 4 & ISEP ! 19G \\
\hline 20.01 & $+1 /$ & BEP \& 8 & $\mathrm{HW}$ & $0, \ln x$ & en & 85P \&: :99i & dL & SEP B 1992 \\
\hline 20.03 & 41 & 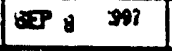 & WH & exp's $\because 42$ & 4 & జ & iN & $\operatorname{ExP} 8$ \\
\hline 20.05 & $N$ & Q & th & SEP, 1992 & $\forall N$ & Eా: 1902 & WN & SESP \\
\hline 20.07 & $\mathrm{HN}$ & $\begin{array}{|ll|}\text { ExP } 8903 \\
\end{array}$ & th & 201, 194 & WN & $8 P_{8}^{8} \cdot 99$ & $\sigma$ & STP \& 1998 \\
\hline 20.09 & WN & Xesp 8 & 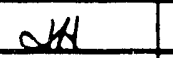 & EP: ...4 & $H$ & 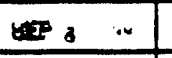 & $\mathrm{AN}$ & EIP: $: 10$ \\
\hline 20.11 & WH & SEP \& 1928 & th & $20 P_{5} \quad, 2$ & sN & SEP : & $W$ & isp? \\
\hline 20.13 & LA & SEP : 292 & th & SEP . 1992 & $\mathrm{HL}$ & SEP : Yen & $W$ & LEP 8 \\
\hline 20.15 & H & $x^{2}=3 \quad 3 x$ & NH & SEP, Q & IN & STP D & $\mathscr{N}$ & $\operatorname{sep}: 82$ \\
\hline 20 & $\mathbb{N}$ & daf $\delta \quad \ldots$ & 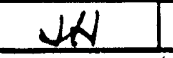 & GEP y N & Wل & $\operatorname{SEP}: \quad$ Mn & $N$ & IAEP, \\
\hline pH & P.H. & -10 ecers & $P H$ & $1 \alpha_{c t a r)}$ & P.H. & $1 \sigma_{\text {(ner) }}$ & P.H & 9 (clear) \\
\hline 20.19 & 10 & SEP \& & $d$ & EP. & ath & CDP & $\underline{N}$ & SEP 1 \\
\hline 20.20 & $\mathrm{NH}$ & SEP \& $\mathrm{sen}$ & $\$ H$ & SEP : 1000 & alN & UIP $8 \mathrm{gii}$ & $\Psi N$ & EEP. \\
\hline 20.21 & NW & SEP 202 & $N$ & ESP: & $w$ & $S E P, E$ & WN & 2 \\
\hline 20.23 & $\mathrm{NS}$ & SEP \& & $\mathrm{HW}$ & $\begin{array}{lll}258 \\
\end{array}$ & WN & Ex, & d & *EP $=$ \\
\hline 20.25 & atr & $3 P_{2}$ as. & adr & EJP. & 211 & SEP : & WN & QEP 8 \\
\hline 20.27 & 20 & SEP : 922 & $\mathrm{HN}$ & $\sec : \mathrm{m}$ & 16 & SEP : & $\$ N$ & ESP \\
\hline 20.29 & SH & Ex: & $\sqrt{4}$ & SEP, & HN & 2059 g is4 & $\forall N$ & $1858 \mathrm{~B}$ \\
\hline 20.31 & $\mathrm{NN}$ & 3. & 14 & Ex \& & oth & EIP a MP & $d x$ & DEP $81+2$ \\
\hline 20.33 & $\times H$ & 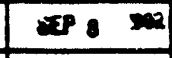 & 5 & 20.12 & atw & Exp. & HN & EEP : \\
\hline 20.35 & 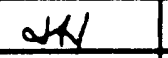 & $3: 1002$ & IE & 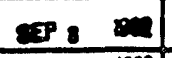 & $\alpha$ & EEP . 1998 & th & EEP . \\
\hline 30.00 & att & 0.1. & SW & 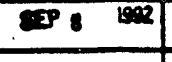 & ath & Ser : 1092 & $\mathrm{Hr}$ & EP : \\
\hline 30.01 & $4 x$ & $25 p_{2}$ & N1 & SEP: :992 & N & SEP \& & th & EEP \& 150 \\
\hline 30.03 & IN & Pap,$x$ & $\mathbb{N}$ & aEP : PeP & $\Delta$ & $\because 88^{1992}$ & He & 4598 \& 165 \\
\hline 30.05 & HW & s]. & $\mathbb{N}$ & $950, \quad 40 x$ & $a / N$ & 102 & He & XEP \& ink \\
\hline 30.07 & 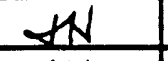 & EEP : Y.92 & $\alpha N$ & $\infty$ & $\alpha$ & EXP: & 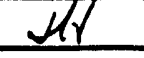 & ESP \& 1998 \\
\hline 30.09 & HN & 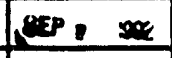 & $Q$ N & 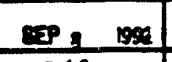 & oft & OEP : 'j: & $4 x$ & EEP 1980 \\
\hline 40.00 & $N / A$ & $\sqrt{1, r^{42}}$ & $V(A+4)$ & $q-842$ & Nla H & 9892 & $M A$ & qf 42 \\
\hline 40.01 & $N 1 A$ & $N_{0.7^{4^{2}}}$ & $N / a$ & 4.512 & NMA & 1842 & NIA & 4842 \\
\hline 40.03 & NIA Vu & $4,3^{12}$ & N/A & .812 & NIA NA & 9.842 & $N \mid A \cup$ & $9-89$ \\
\hline 50.00 & WN & Es: & $x$ & 토. & 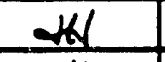 & $\sec : \quad$ & 4 & EEP: 1992 \\
\hline 50.01 & QN & exp & W & ExP: $\quad 992$ & a.ll & SEP \& 1942 & $2 \times$ & 858 \& 992 \\
\hline 50.03 & 4 & .78 & $k /$ & Yxp: & $\mathrm{Nat}$ & ${ }_{1}$ & th & 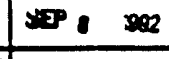 \\
\hline 50.05 & Nis and & 9.192 & NA $+x$ & 9142 & N)A $\mathrm{WI}$ & $a^{-892}$ & NLA & $5-892$ \\
\hline 50.07 & Sten & Ext & $x$ & ESP : & $M$ & 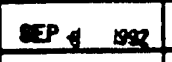 & 4 & EEP 1 \\
\hline 50.09 & 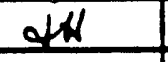 & Ex: 1992 & att & SEP \& :992 & له. & EsP \& i992 & لئل & SEP \& 1992 \\
\hline 50.11 & $d N$ & 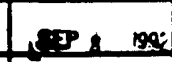 & $J$ & 198 & 24 & CEP : isis & $\mathrm{HN}$ & 1 \\
\hline 50.14 & $H$ & $9-3-52$ & 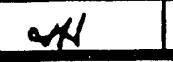 & $9-3-12$ & $O W$ & $9-3-92$ & $M$ & $1-3-52$ \\
\hline
\end{tabular}

BAR CODE NUMUERS ARE THE WAT THESE NUMBERS IN THE COOE WW 9-892

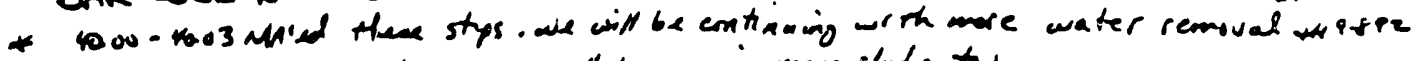

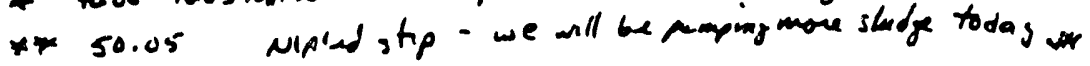

All of thear dieums the sludge was pumped into skdge drum 3 


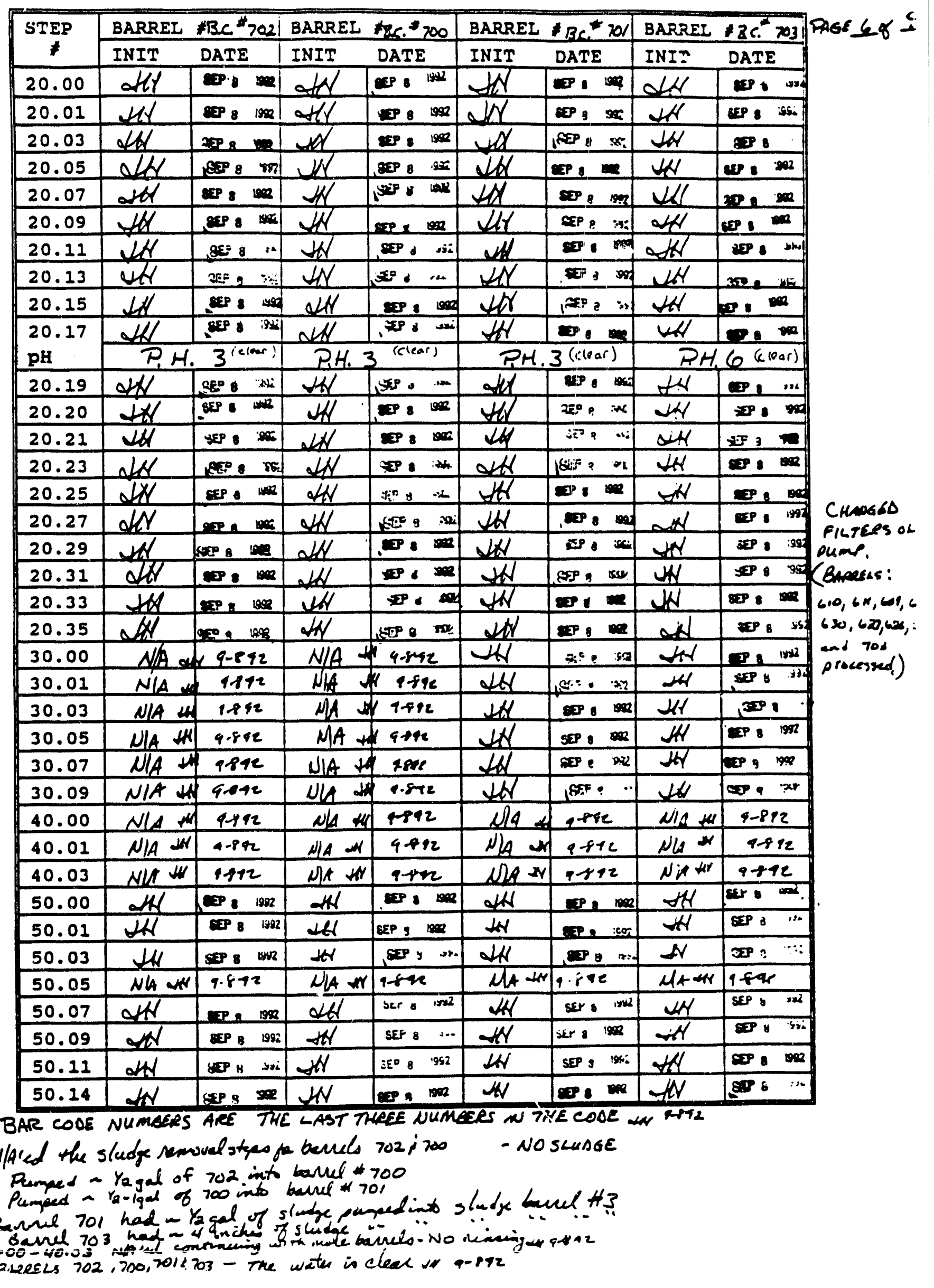

B-17 


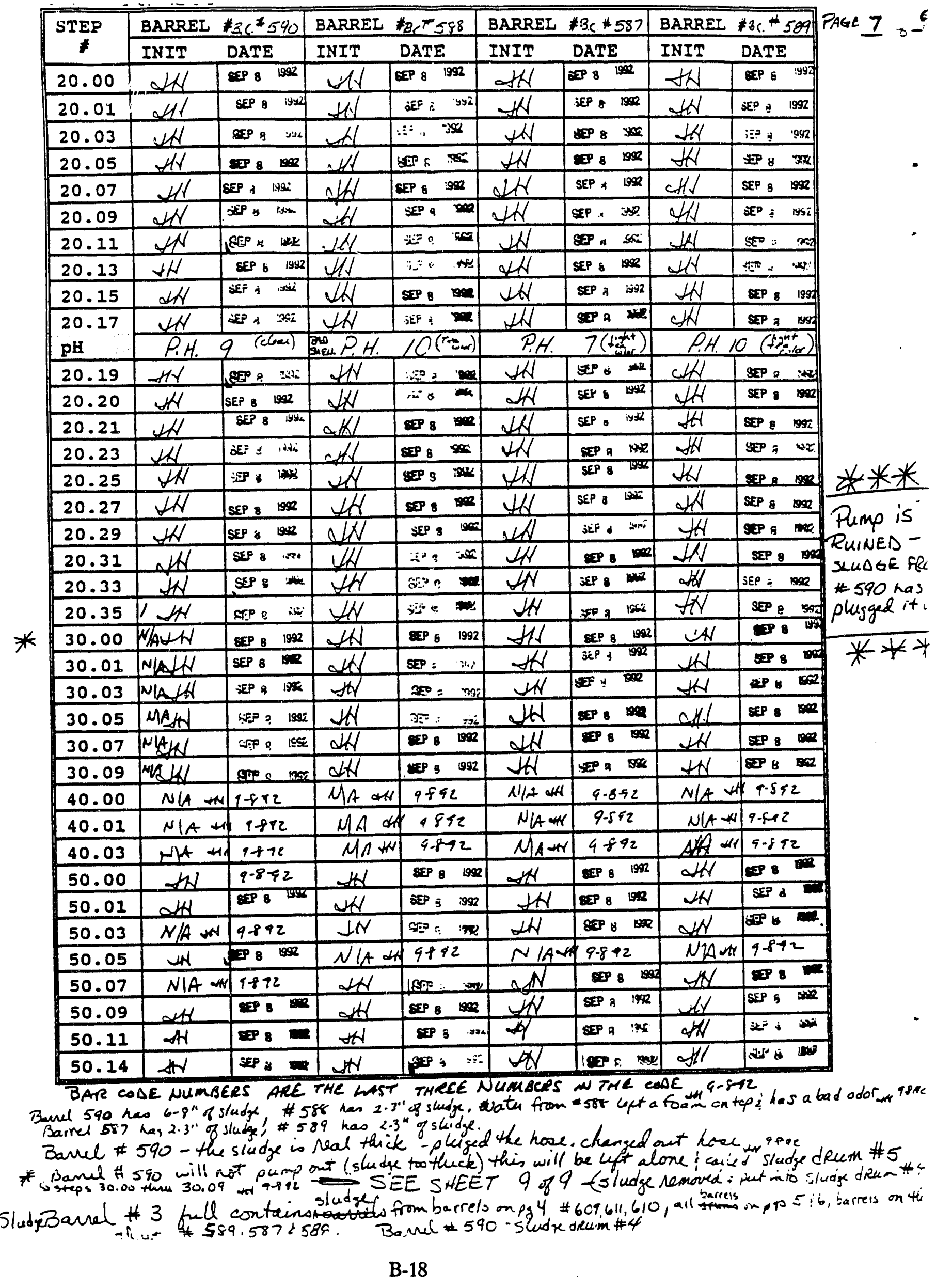


$B C=$ BAR CODE

SWR 92 F08 RECORD SHEET

\begin{tabular}{|c|c|c|c|c|c|c|c|c|c|}
\hline \multirow{2}{*}{$\underset{\#}{\operatorname{STEP}}$} & \multicolumn{2}{|c|}{ BARREL $\quad * 3 C \quad 525$} & \multicolumn{2}{|c|}{ BARREL \#BC. 376} & \multicolumn{2}{|c|}{ BARREL $\# \& C .572$} & \multicolumn{2}{|c|}{ BARREL \#BC. ${ }^{7} 571$} & \multirow{2}{*}{ Pase 8 of 9} \\
\hline & INIT & DATE & INIT & DATE & INIT & DATE & INIT & DATE & \\
\hline 20.00 & $2+N$ & & atth & ERP O & $c+t$ & BEP : ing? & \&4 & sex: & \\
\hline 20.01 & Nh & \begin{tabular}{|l|} 
SEP O 1992 \\
\end{tabular} & $a$ N & SEF : & th & SEF 6 & HW & SEP \& 1008 & \\
\hline 20.03 & WN & $\begin{array}{ll}\text { SEEP O } 1992 \\
\end{array}$ & Wh & तह & HN & SifF $=\quad \because ?$ & $n+4$ & SEP O অ & \\
\hline 20.05 & WN & SEP O :00: & N & set. & $H$ & SEP O 1992 & .41 & $\therefore \equiv ;$ & \\
\hline 20.07 & LA & $\dot{B} z=+\cdots$ & Het & $\because$ & 4 & SEP y & 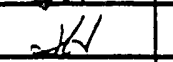 & $\because \cdot$ & \\
\hline 20.09 & ath & $n=: \quad \cdots$ & SH & ifr & $\forall x$ & $x=; \quad 1040$ & DSt & 85P , 1992 & \\
\hline 20.11 & th & \begin{tabular}{|ll} 
SEP O 1992 \\
\end{tabular} & $+N$ & $\because \quad 1992$ & $\mathrm{HH}$ & 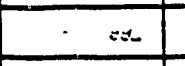 & stir & \begin{tabular}{|l|l|}
$\sin 2$ \\
\end{tabular} & \\
\hline 20.13 & על & 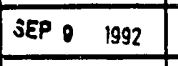 & $\perp N$ & SEP 9 1992 & tN & os: : & $\sqrt{14}$ & $25=.14$ & \\
\hline 20.15 & W & $x=3$ i94: & HN & 5 & WN & 3932 & $H$ & CE: $=\ldots . . .1$ & \\
\hline 20.17 & HI & $\because \div 35$ & $4 r$ & $J E: ; \quad \varepsilon$ & $d A$ & $\because E-=6$ & N & 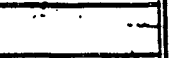 & \\
\hline $\mathrm{pH}$ & PH & 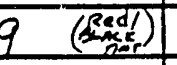 & P.H. & (jer & P.H. 8 & 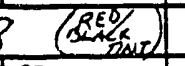 & P.H. & 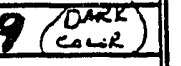 & \\
\hline 1.19 & सt & $\because ; \quad \because$ & HI & हु. & $\sqrt{6}$ & \begin{tabular}{|ll} 
SEP O & 1992 \\
\end{tabular} & $\mathrm{HH}$ & SEP O 1992 & \\
\hline 20.20 & $4 N$ & SEP \& 1002 & $\Delta N$ & $s t=, i s E_{-}$ & Wh & $i=0, \ldots$ & H.1 & SEP O $19:$ & \\
\hline 20.21 & SW & SEP Q 1992 & UN & $: \quad 1992$ & 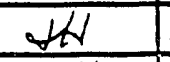 & JEF, PS & str & $\because \because 0$ & \\
\hline 20.23 & HN & $\because, \quad 9312$ & $\Delta$ & $3 E^{\circ}+1992$ & $x^{N}$ & $\because: s$ & $2 / 1$ & $\because: \because \quad \because$ & \\
\hline 20.25 & W/ & sed: & 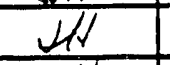 & \begin{tabular}{ll|} 
SEP 9 & 1992 \\
\end{tabular} & $t^{4}$ & 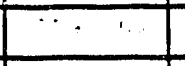 & wh & SEP O & \\
\hline 20.27 & $\forall$ & : & $\mu$ & $=4$ & HA & Eff. . . & IN & $\begin{array}{|ll|}850 & \\
\end{array}$ & \\
\hline 20.29 & N & SEP : $\quad 992$ & स्रा & F! ISE & $\$ N$ & SEP _ _ & $d N$ & $j=2$ & $=$ \\
\hline 20.31 & Hh & \begin{tabular}{|l|l|} 
SEP O & 1952 \\
\end{tabular} & $W$ & $\because$ & IN & SEP \& dop & th & 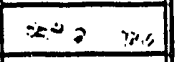 & \\
\hline 20.33 & Ht) & $S E=: \quad$ a & 5ل & $.7 F^{2}=.1992$ & N & 1982 & $\mathrm{HN}$ & $\therefore ; \quad$ stris & \\
\hline 20.35 & $\Delta A$ & $\because \because=$ i & $2+4$ & SEP o 1992 & स & 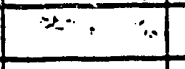 & $H$ & SEP o & RERAED fum \\
\hline 30.00 & othl & $\because \quad \quad$.ntor & $\mathrm{IN}$ & $\begin{array}{ll}\text { SEP O } & 1992 \\
\end{array}$ & dt & SF..... & $\Delta / 1$ & $5=2$ & OEFORE DESANT \\
\hline 30.01 & WN & \begin{tabular}{|l|} 
SEP D 1992 \\
\end{tabular} & $2+1$ & $\begin{array}{|ll|}8 F_{\mathrm{F}} \quad \therefore . \\
\end{array}$ & $\Delta$ & $\begin{array}{|ll|}\text { SEP O } & 199 ? \\
\end{array}$ & N & $\cdots$ & OF TMESE \\
\hline 30.03 & 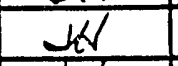 & SE? , 1992 & MH & 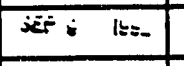 & W & $85 P_{0} \quad$ IGc- & Kt & 2es? & erELS. \\
\hline 30.05 & 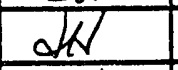 & $s=0$ & LH & SEFP of ISS? & W & $350, \cdots$ & NH & E्य户 O & \\
\hline 30.07 & $\mathrm{JH}$ & 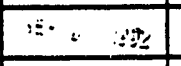 & Ht & Verp o 195: & th & $\therefore \quad$. & $\Psi N$ & SEP \& $\quad 1992$ & \\
\hline 30.09 & $\Delta$ & 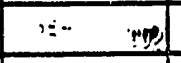 & 4 & \begin{tabular}{|ll} 
SEP O 1992 \\
\end{tabular} & $\mathrm{NH}$ & 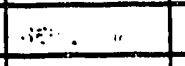 & 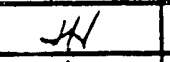 & $i \pm \nu+\quad ; \in 2$ & \\
\hline 40.00 & Nld d & 9942 & NIA UI & $a-1+2$ & M & 9742 & $M A$ & 4442 & \\
\hline 40.01 & MA wir & $94+2$ & $N \mid A+A$ & $9+12$ & N/L +W & 91.92 & $N / A-x$ & $1+442$ & \\
\hline 40.03 & $N / A$ & 9442 & $\mu A+$ & $4 i+2$ & NIA $+L$ & $9+12$ & $M_{A}+\infty$ & $1++2$ & \\
\hline 50.00 & HN & \begin{tabular}{|ll} 
SEP O & 1992 \\
\end{tabular} & It & 645 . & N & EP, 1992 & $\mathrm{HN}$ & SEP o & \\
\hline 50.01 & $\mathrm{HN}$ & SxP O 1992 & HN & SE?: & Wh & CEP \& 1992 & Lt & $\begin{array}{ll}\text { SEP O } & 1992 \\
\end{array}$ & \\
\hline 50.03 & $\forall A$ & ges, 3 & $I N$ & Ses; 2 & $\Delta H$ & $\partial E^{\circ}, 1992$ & st & $i E^{2}$. & \\
\hline 50.05 & $d \mid A$ sN & $9-9-92$ & $M / A \mu_{r}$ & 9412 & MAA A & $1+12$ & $N / A-W$ & $9+12$ & \\
\hline 50.07 & otd & s? & मस & SEP \& $\quad ; 6$ & $\$$ & $\therefore$ & $M$ & $5=$ & \\
\hline 50.09 & 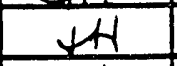 & $s e$ & st & SEP O 1992 & thI & 2EP D $\quad 1992$ & NA & $\because$ & \\
\hline 50.11 & $\$ N$ & SEP O & Ht & SEE: . A & $M$ & SEP O $\quad 1998$ & $\mathbb{N}$ & \&FT: & \\
\hline 50.14 & Av & SEP \& 1992 & 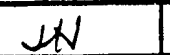 & SEP J :99: & $M$ & Axpo iss: & $H N$ & Sor $-\quad-1$ & \\
\hline
\end{tabular}


$B C=10 x: \operatorname{cod} z$

SWR 92F08 RECORD SHEET

\begin{tabular}{|c|c|c|c|c|c|c|c|c|}
\hline \multirow{2}{*}{$\begin{array}{c}\text { STEP } \\
\neq\end{array}$} & \multicolumn{2}{|c|}{ BARREL \#6C ${ }^{\neq} 564$} & \multicolumn{2}{|c|}{ BARREL \#590 } & \multicolumn{2}{|c|}{ BARREL \# } & \multicolumn{2}{|c|}{ BARREL $\#$} \\
\hline & INIT & DATE & INIT & DATE & INIT & DATE & INIT & DATE \\
\hline 20.00 & $3 / N$ & 20001 od 33 & & 7 & & & & \\
\hline 20.01 & UN & SEP 9 ' $95 i$ & & 1 & & & & \\
\hline 20.03 & $+N$ & GEP: & & 1 & & & & \\
\hline 20.05 & 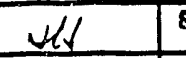 & EJP : 1992 & & 1 & & & & \\
\hline 20.07 & $\mathrm{HH}$ & SEP o 1092 & & 1 & & & & \\
\hline 20.09 & Wh & SEP \& IOS: & & 1 & & & & \\
\hline 20.11 & Hh & SEP Q 1992 & & 1 & & & & \\
\hline 20.13 & H & EP O 1992 & & $T$ & & & & \\
\hline 20.15 & $d N$ & SEF: $\cdot \cdot$ & & V/4 & & & & \\
\hline 20.17 & $H$ & BeP 2 19F & & $a^{a^{2}}$ & & & & \\
\hline $\mathrm{pH}$ & PH. Q & $\left.\begin{array}{c}\text { smote } \\
\text { coloerd }\end{array}\right)$ & $y$ & & & & & \\
\hline 20.19 & SH & $\begin{array}{r}1992 \\
\end{array}$ & & & & & & \\
\hline 20.20 & $d t$ & SFP Q & & & & & & \\
\hline 20.21 & H & SEP o & 1 & & & & & \\
\hline 20.23 & $\forall N$ & SEP. M & I & & & & & \\
\hline 20.25 & $d N$ & SEP: $: y$ & 1 & & & & & \\
\hline 20.27 & KN & $\rightarrow n, \quad 900$ & 7 & & & & & \\
\hline 20.29 & It & SEP : . CC. & I & & & & & \\
\hline 20.31 & $\mathrm{AH}$ & SEP : 1952 & 7 & & & & & \\
\hline 20.33 & HN & $\vdots F=:$ : & 1 & & & & & \\
\hline 20.35 & IH & $=\ldots$ & 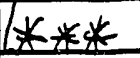 & & & & & \\
\hline 30.00 & HH & $\begin{array}{|ll|}\text { SEP \& } 1902 \\
\end{array}$ & W & & & & & \\
\hline 30.01 & Not & SEP O 1992 & SH & & & & & \\
\hline 30.03 & $d N$ & $\therefore E=, \quad \log 8$ & $H$ & & & & & \\
\hline 30.05 & $H$ & $3 E=9$ lase & $\Delta$ & & & & & \\
\hline 30.07 & $\pm t$ & $x \in=2 y$ & 2 & & & & . & \\
\hline 30.09 & $H$ & $5:$ & $\mathrm{HN}$ & & & & & \\
\hline 40.00 & $N(A)$ & $1-412$ & $\mathrm{HN}$ & & & & & \\
\hline 40.01 & $N(A)$ & $9-9-42$ & all & & & & & \\
\hline 40.03 & NIA & 9442 & W & & & & & \\
\hline 50.00 & $H 1$ & SEP : & WN & & & & & \\
\hline 50.01 & $\mathrm{HH}$ & SEPQ & $d N$ & & & & & \\
\hline 50.03 & IVIA N & $9-9+2$ & ot & & & & & \\
\hline 50.05 & ath & 900 & $N$ & & & & & \\
\hline 50.07 & N/A & SEF $=\cdots$ & att & & & & & \\
\hline 50.09 & M & gape. & H & & & & & \\
\hline 50.11 & $\alpha N$ & SEP o loge & H & & & & & \\
\hline 50.14 & 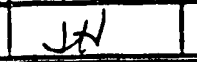 & sap. & 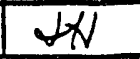 & & & & & \\
\hline
\end{tabular}

* 590 was brougt back in the shop. Ad ded $1.2 \mathrm{gal}$ of waste unater ferm Barre \# 590 was brought mack in the the thich sludas. Sludge was then pumped into sludge beurel \#4 in 9 -942 


\section{PRE-JOB BRIEFING SHEET}

\section{Date: $9 \cdot 2-92 \quad$ Time: 0730}

Description of job to be accomplished: Pretrieat ciaste contanu in 33 dirums

Applicable Documentation (if any): Planningy she-kts frow Surk92fue

SWR \# 92 fo 8 DOP\#

Other

All personnel understand all applicable aspects of the job to be performed, the associated hazards, and the actions that are or will be taken to mitigate those hazards.

Job Supervisor Raw $\frac{K \text { Eluod }}{\text { (Print) }}$

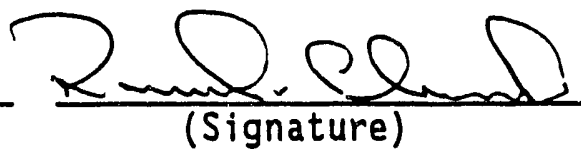

\begin{tabular}{|c|c|c|c|}
\hline $\begin{array}{c}\text { NAME } \\
\text { (Print) } \\
\end{array}$ & INITIALS & $\begin{array}{l}\text { "S" } \\
\#\end{array}$ & $\begin{array}{c}\text { ORG } \\
\#\end{array}$ \\
\hline Chere-moragn & chn & 57253 & FAD \\
\hline$E d \quad I A N G$ & 21 & 501699 & 7210 \\
\hline STEUE PRTER & & 35009 & 7220 \\
\hline ILENE HoRRELL & Sift & 45638 & 7220 \\
\hline John S. Cummings & Ate & 63594 & 7220 \\
\hline$R_{E x} B F_{1 R T H}$ & $3235 y^{2}$ & 68318 & 7220 \\
\hline Revin Streven & 21 & $3<1795$ & 7220 \\
\hline Enest C Garcia & 2 & 59810 & 7320 \\
\hline Bol Brancon & $R B$ & 22325 & 2230 \\
\hline Crang Barales & $\operatorname{cs} \beta$ & 38517 & 7230 \\
\hline Brian J/siesen & $B 7$ & $5 \% 812$ & 5830 \\
\hline D.G. COOK & ese & 20944 & 2220 \\
\hline & & & \\
\hline & & & \\
\hline
\end{tabular}


SKR NO:

22F08

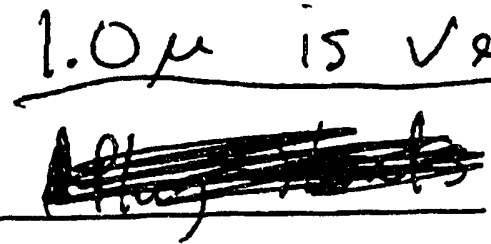

Title:

WASTE PRBTREATMENT FOR THE PHTU

Rev. No. 0

Subject: TAN WASTE FILTRATION

\section{APPENDIX A - FILTER REPLACEYIBNT}

Appendix A describes the steps necessary to replace the filters in the waste water filtering unit. Since this procedure may be performed several times initial the aign off matrix on page $A-3$ as each step is performed.

A.1 FIITER REPLACEBBaT an 9-3-92 after processing 12 barrels also ckanged out the hoses A.1.1 Write the date this Appendix is performed.

A.1.2 Verify valve 4 is closed.

A.1.3 Verify valve 3 is open.

A.1.4 Verify that there is no pressure in the system. If there is presaure in the syetem place the recycle line into the waste drum with the inlet line and open valveg, and? open the vent.plugs at the top of the filter housings. Use a dipposable wipe to absorb any leakage.

A.1.5 Obtain the proper micron replacement filter.

A.1.6 Remove the four retaining nuts from the top of the filter housing.

A.1.7 Using disposable swipes to catch any spills remove the cover plate on the filter housing.

A.1.8 Using a pliers or other grasping tool, remove the filter. place the filter into a radiation bag. A.1.9 Hold at this polnt for a sample of the sludge on the filter to be
taken. Follow the approved sampling analysis plan for this step. rote, this stop $\mathrm{na}$ be anked not applicable (in) with project enangors or designated ilternates approval.

A.1.10 Add excess absorbent to the filter in the radiation bag. place the bagged filter into a radioactive wate drum. The filtera will be sent to tbe MWSF pending TCUP torte for the eludge waste.

. I. 11 Place the new filter into the filter housing. Make Bure the proper micron fliter is placed into the housing, and that the filter is properly allgned.

SHR MO: 92F08

Page No. A-2

Title: HASTE PRETREATYINT FOR FET PWTO

Rev. No. 0

subject: TaN HASTY PIITRATIO

A.1.12 Replace tho cover plate and bolt it in place. 
A. 1.13 Close valve 2

A.1.14 Open valves 1 and 3 .

A.1.15 slowly open valve 4 to resume filtering. Observe the housing to verify there 18 no leakage.

A.i.16 Return to section 4.2 .8 
Subject: TAN WASTH. PILFRATION

\section{APPEINDIX A SIGN-OFT TABLS}

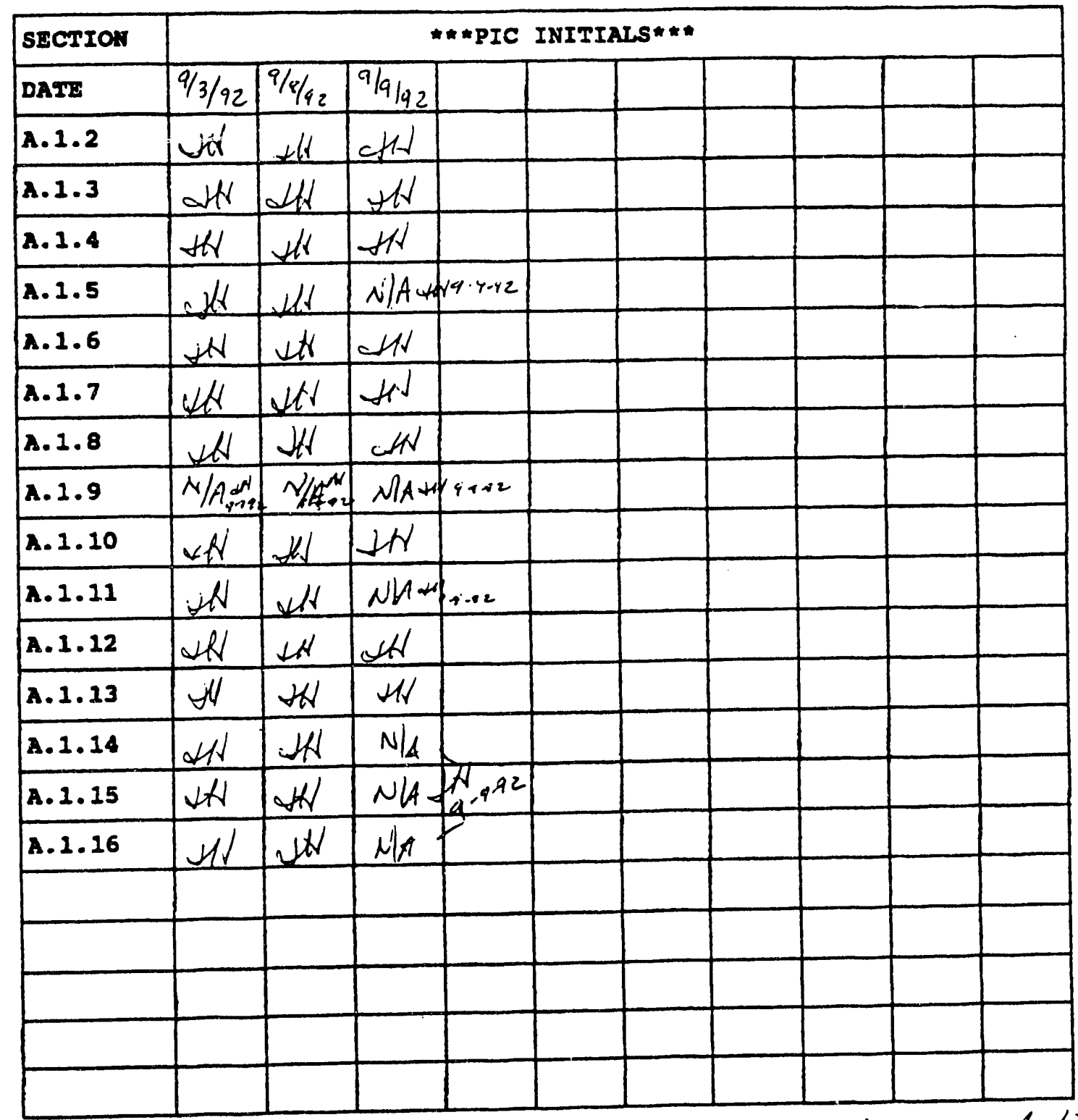

on 9-9-92 we renoved all fitenficom system and did not replece them. Job is comple.te at this terme 


\section{Appendix C}

\section{Resin and Resin Column Vendor Data}




\title{
RESIN RECLAMATION CHAMBER
}

\author{
MODELS: CL630RS-1 \\ CL640RS-1 \\ CL660RS-1 \\ 'CUL630R-F1
}

PRICE CODE NOS.: 2702

2703

2704

0375A

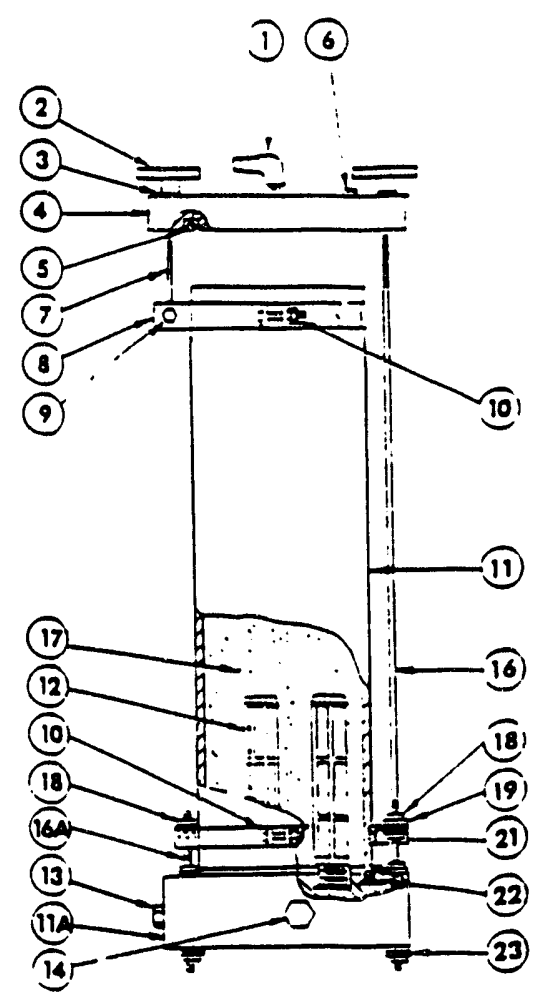

\begin{tabular}{|c|c|c|c|c|}
\hline \multirow{2}{*}{ RESIN } & cu.FT. & cu.FT. & cU.FT. & $\begin{array}{l}10 \text { or mors } \\
\text { cu.t. } \\
\text { (por cu. th) }\end{array}$ \\
\hline & \multicolumn{4}{|c|}{ PAICE CODE NUMBEAS } \\
\hline \multirow{2}{*}{$\begin{array}{l}\text { For precious } \\
\text { motal recovery } \\
\text { Alkaline } \\
\text { Acid }\end{array}$} & 1314 & 1315 & 1318 & 1317 \\
\hline & 1320 & 1321 & 1322 & 1323 \\
\hline $\begin{array}{c}\text { For delonizing } \\
\text { water mixed } \\
\text { bed resin } \\
\text { (DWI) }\end{array}$ & 1326 & 1327 & 1328 & 1329 \\
\hline
\end{tabular}

When ordering, indicate quandty (Price Code No.) requered.

-Chambers with acrylic shells do not use swing bolts. "Recommended spare parts.
Refer to Operation and Service Guide 0.930 and Master Price Llat F.800

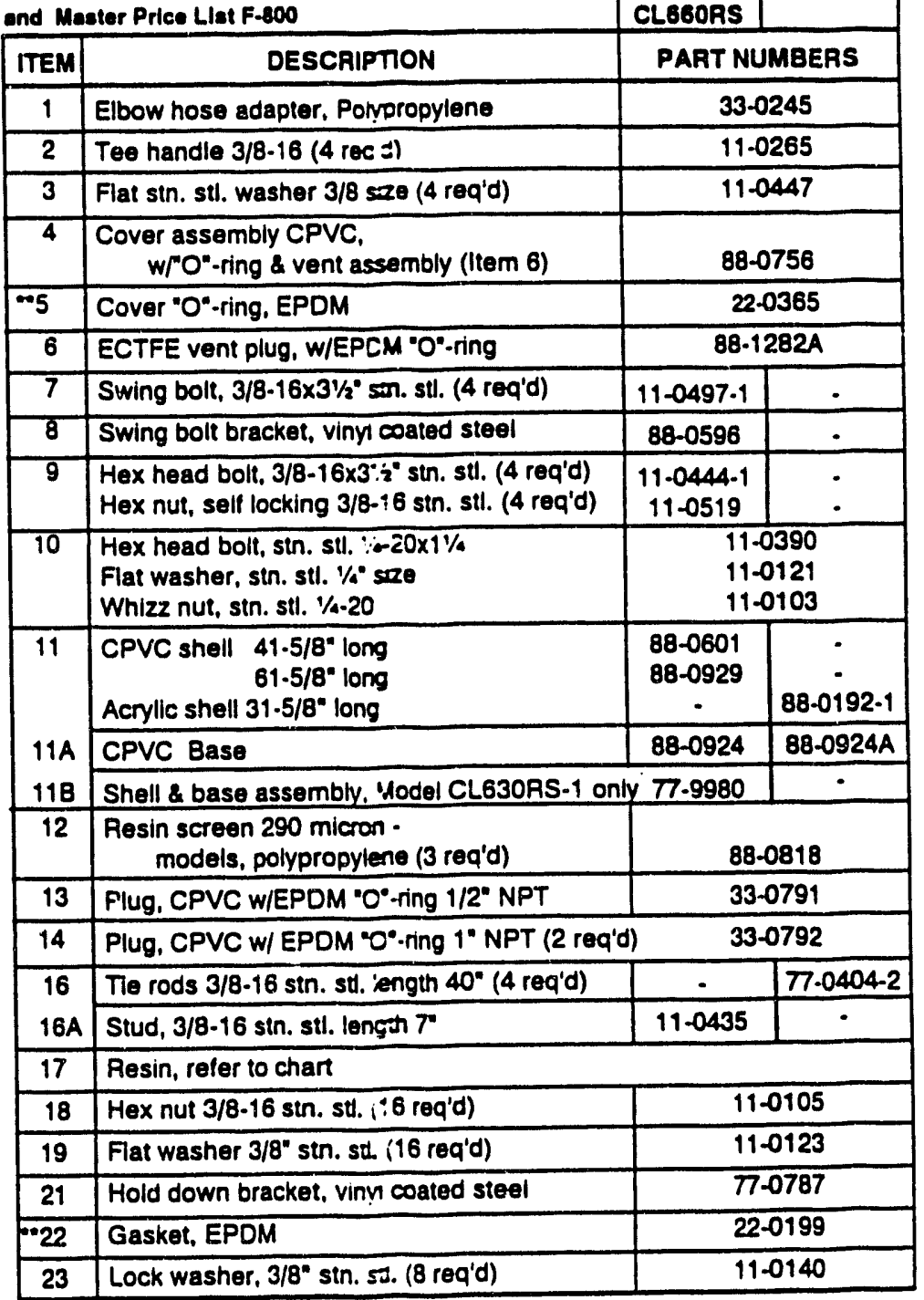
.

MODELS

\begin{tabular}{|l|l|}
\hline \multicolumn{2}{|c|}{ MODELS } \\
\hline $\begin{array}{l}\text { CL630RS } \\
\text { CL640RS } \\
\text { CL660RS }\end{array}$ & CUL630R \\
\hline
\end{tabular}




\section{PRODUCT DESIGN}

Purolite $\mathrm{C} \cdot 100 \mathrm{H}$ is a premium grade cation exchanger that can be used in water demineralization. $\mathrm{C}-100 \mathrm{H}$ is produced exactly the same as Purolite C-100, using a crosslinked styrene divinylbenzene polymer matrix with $8 \%$ crosslinking. Bead stability and a minimum of $95 \%$ whole clear beads make $\mathrm{C}-100 \mathrm{H}$ a premium grade gel without the added cost of buying an uograded cation produc!. The data presented ierein are applicable for hydrogen cycle cation exsmange operation only. For sodium cycle information see C.100.

\section{Typical Chemical and Physical Characteristics}

Polymer Structure...............Polystyrene crosslinked with divirybenzene Functional Groups . . . . . . . . . . . . . . . . . . . . . . . R- R Physical Appearance. . . . . . . . . . . . . . . . . . . Clear Sphercal Beads lonic Form (as shioded) . . . . . . . . . . . . . . . . . . . . . Hydrogen Screen Size, U.S. Std. Mesn (Wet) . . . . . . . . . . . . . . . . . . 16-45 Particle Size Range . . . . . . . . . . . . . . . . 16 mesh $<5 \%, .50$ mesh $<1 \%$ Water Retention . . . . . . . . . . . . . . . . . . . . . . 49.55\%

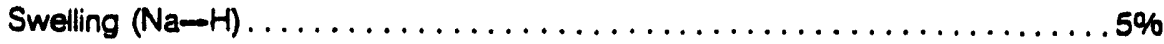

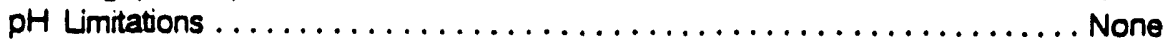
Temperature Limitations . . . . . . . . . . . . . . . . . . . . 280 $20^{\circ}\left(140^{\circ} \mathrm{C}\right)$ Whole Clear Beacs . . . . . . . . . . . . . . . . . . . . 95\% minimum

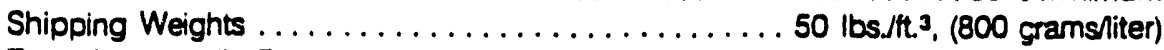
Total Capacity (H Form) . . . . . . . . . . . . . $1.8 \mathrm{meq} / \mathrm{ml}$. minimum Volumetric 4.9 meq/gm. minimum Weight Standard Packaging . . . . . . . . . . . . cu. th polyethyiene-lined foer drums

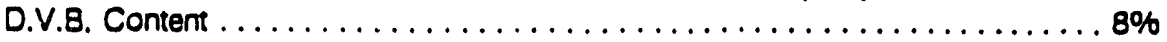
Color . Black or Amber 


\section{STANDARD OPERATING CONDITIONS}

\begin{tabular}{|c|c|c|c|c|}
\hline Operation & \multirow{2}{*}{$\begin{array}{l}\text { Rate } \\
1.500 \mathrm{~m} / \mathrm{ft}^{3}\end{array}$} & Solution & Minutes & Amount \\
\hline Service & & Influent Water & & \\
\hline Backwash & $\begin{array}{l}3-5 \mathrm{gpm} / \mathrm{ft}^{2} \\
\left(40-60^{\circ} \mathrm{F}\right)\end{array}$ & Influent Water & $5-20$ & $10-25$ gals. $/ \mathrm{ft}^{3}$ \\
\hline Regeneration & $0.2-0.8 \mathrm{gpm} / \mathrm{ft}^{3}$ & $\begin{array}{l}0.5-5 \% \mathrm{H}_{2} \mathrm{SO}_{4} \\
4-10 \% \mathrm{HCl}\end{array}$ & 30 & 4-10 lbs. \\
\hline Rinse (Slow) & $0.2-0.8 \mathrm{gpm} / \mathrm{ft}^{3}$ & Decationized & 60 & 20 gals $/\left(\mathrm{tt}^{3}\right.$ \\
\hline Rinse (Fast) & $1-5 \mathrm{gpm} / \mathrm{ft}^{3}$ & Decationized & 60 & 30 gals. $/ f^{3}$ \\
\hline $\begin{array}{l}\text { Backwash E } \\
\text { Design Risin }\end{array}$ & $\begin{array}{l}50-75 \% \\
100 \%\end{array}$ & & & \\
\hline
\end{tabular}

Stepwise Regeneration of Purolite C. $100 \mathrm{H}$

\begin{tabular}{|c|c|c|c|c|}
\hline $\begin{array}{c}\text { Regeneration Level } \\
\text { Ibs. }\left(66^{\circ} \mathrm{Be}\right) \\
\mathrm{H}_{2} \mathrm{SO}_{1} \mathrm{per}^{\mathrm{Cu} . \mathrm{Ht}} \\
\text { Resin }\end{array}$ & $\begin{array}{c}\text { Ibe. }\left(66^{\circ} \mathrm{Be}\right) \\
\mathrm{H}_{2} \mathrm{SO}_{4} 2 \%\end{array}$ & $\begin{array}{c}\text { Ibs. }\left(66^{\circ} \mathrm{Be}\right) \\
\mathrm{H}_{2} \mathrm{SO}_{4} 4 \%\end{array}$ & $\begin{array}{c}\text { Ibs. }\left(66^{\circ} \mathrm{Be}\right) \\
\mathrm{H}_{2} \mathrm{SO}_{4} 6 \% \\
\end{array}$ & $\begin{array}{l}\text { Ibs. (66. Be) } \\
\mathrm{H}_{2} \mathrm{SO}_{4} 8 \% \\
\end{array}$ \\
\hline 3 & 2 & 1 & - & - \\
\hline 4 & 2 & 2 & - & - \\
\hline 5 & 2 & 3 & - & - \\
\hline 6 & 2 & 3 & 1 & - \\
\hline 7 & 2 & 3 & 2 & - \\
\hline 8 & 2 & 3 & 3 & - \\
\hline 9 & 2 & 3 & 3 & 1 \\
\hline 10 & 2 & 3 & 3 & 2 \\
\hline
\end{tabular}

Purolite $\mathrm{C}-100 \mathrm{H}$ when exhausted with a high amount of calcium should be regenerated with nydrochioric acid to prevent precipitation. Due 10 availability and cost. hydrochloric acid may not be ine regenerant of choice. Then. sulfuric acid can se usec. Hign amounts of calcium can cause precipitation but could be minimized if a stepwise regeneration is used. By starting your regeneration with a low percentage of sulfuric acid ( $2 \%$ or less) and gradually increasing. precipitation can be avoiced (see table above). 


\section{CAPACITY}

Purolite $\mathrm{C}-10 \mathrm{OH}$ Sulfuric Acid Regeneration (stepwise)

Intluent 200 ppm TOS as CaCO, 36" Bed Oeoin 2 gal/min/cu.ll.

Figure 1.

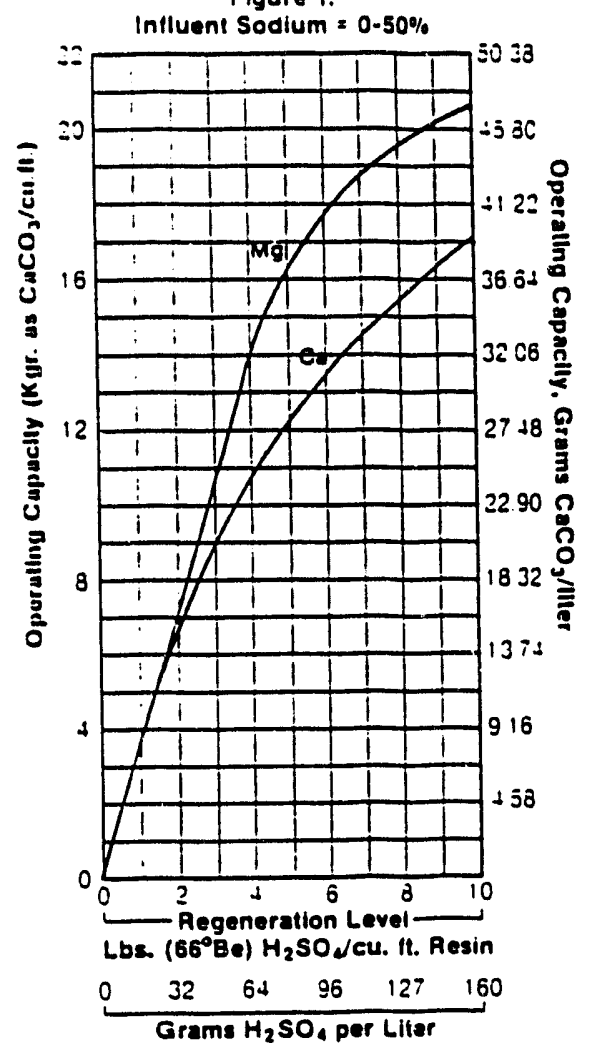

Figure 3.

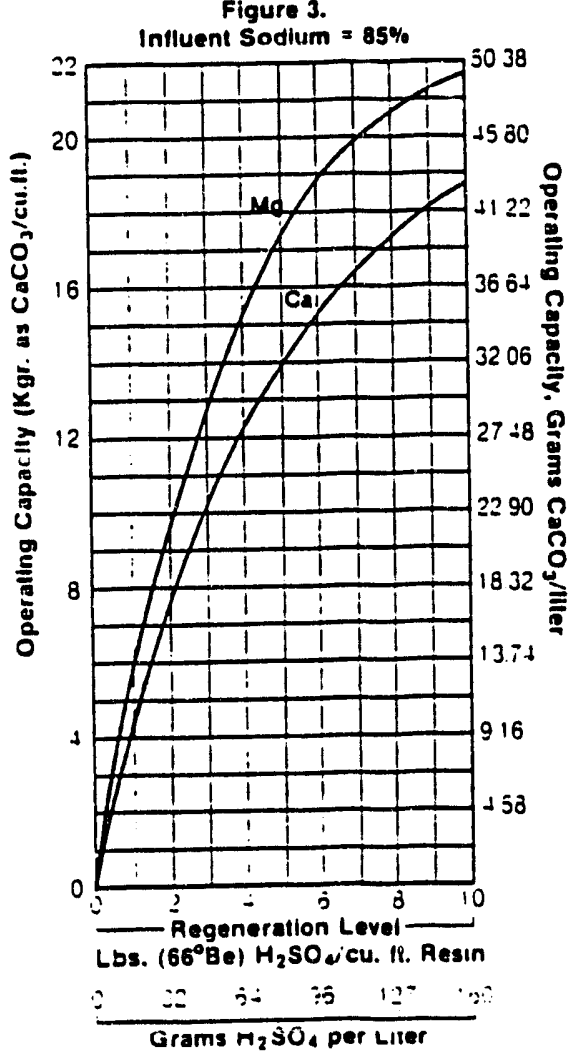

Figure 2.

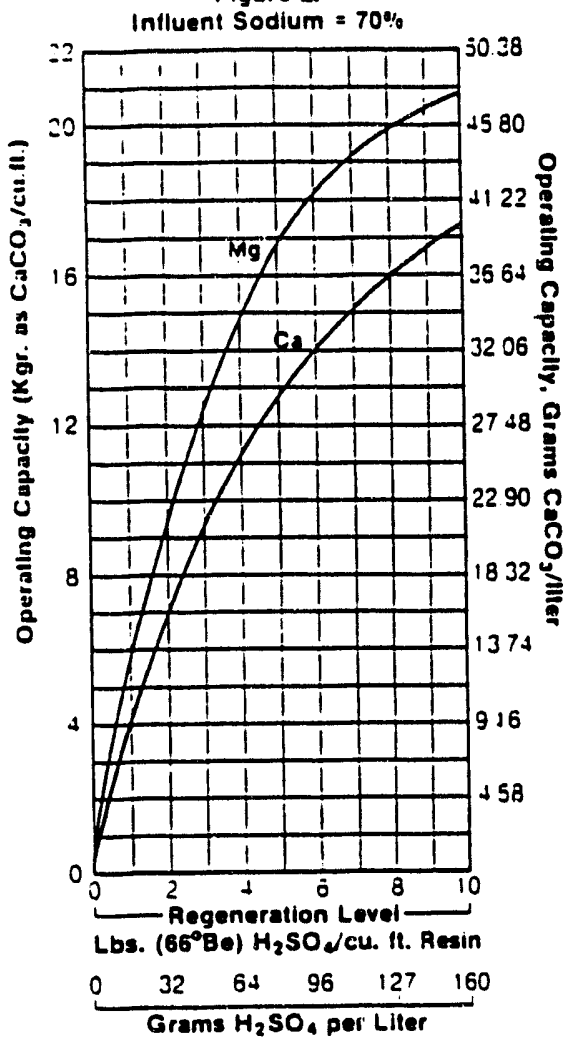

Figure 4.

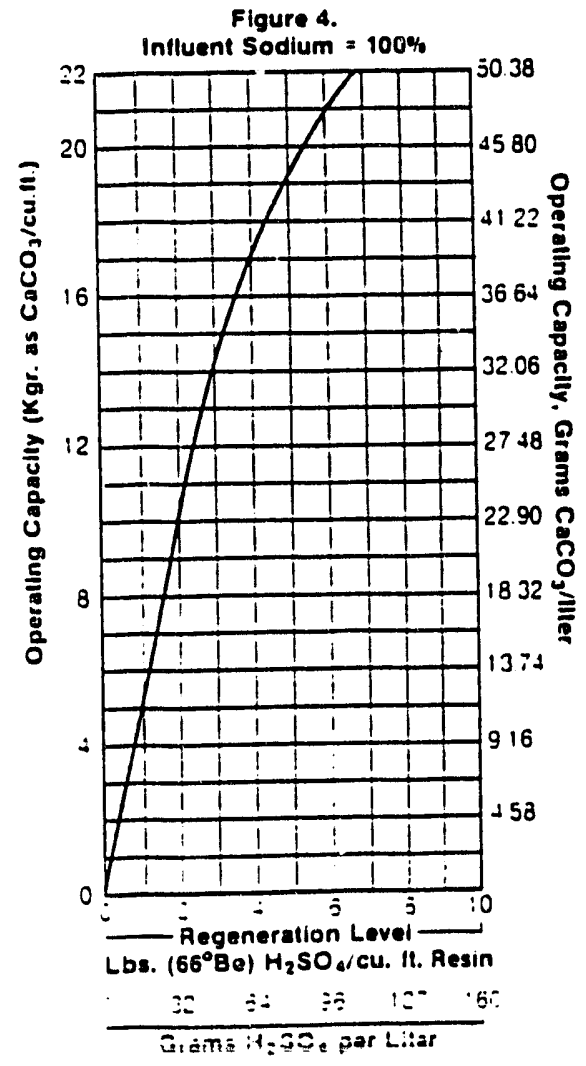


Figure 5

FLOWAATE CORAECTION

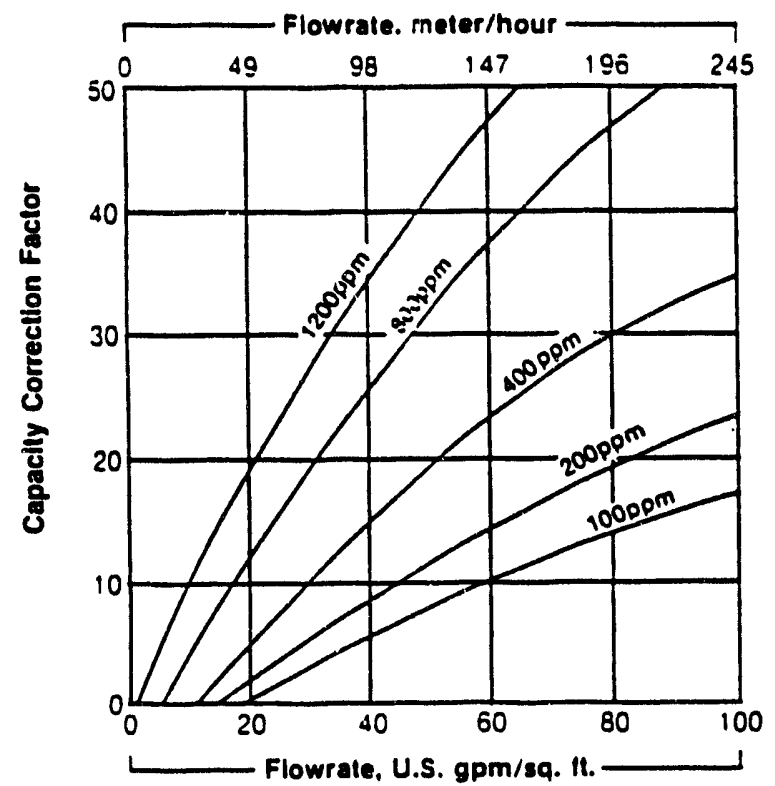

Figure 6.

ALKALINITY CORRECTION

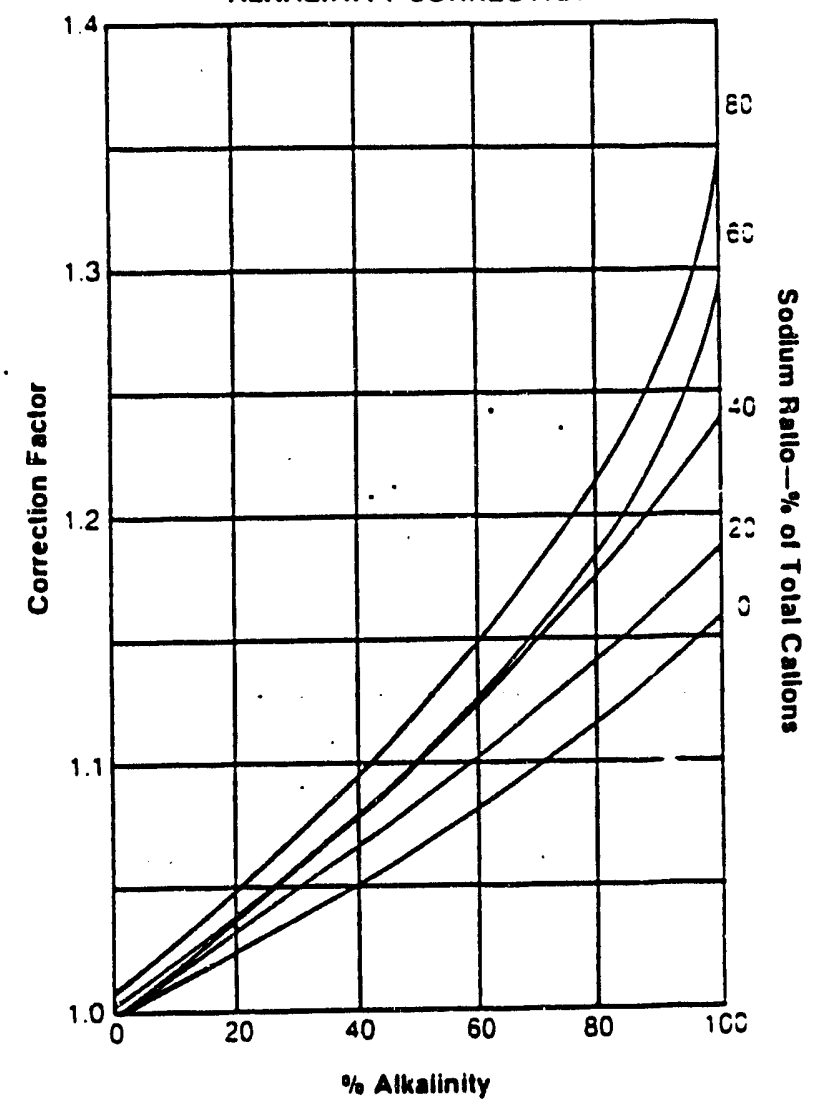

\section{Example:}

Regeneration at 6 pounds $\mathrm{H}_{2} \mathrm{SO}_{4}$ at $10 \mathrm{gpm} / \mathrm{sq}$. $\mathrm{tt}$.

\begin{tabular}{|c|c|}
\hline $\begin{array}{l}\text { Cations } \\
\text { Ca...100 } \\
\text { Mg...100 } \\
\text { Na...200 }\end{array}$ & $\begin{array}{c}\text { Anions } \\
\mathrm{CO}_{3} \ldots 160 \\
\mathrm{Cl} . . .140 \\
\text { SO }_{4 . . .100}\end{array}$ \\
\hline 400 & $\ldots . .400$ \\
\hline
\end{tabular}

1. Determine your base operating capacty from Figure 1.

2. Determine alkalinity correction from Figure 6.

3. Determine your flowrate correction frem Figure 5.

4. Determine temperature correction factor " $K$ " trom Figure 16.

Base Operating Capacity

$\times$ Alkalinity Correction

$x$ Flowrate Correction

$x$ " $K$ " Temperature Correction

$15.5 \times 1.07 \times 1.0 \times .96=16.6$ Kilograins/cu. .5

5. Leakage is determined from Figures 7 through 12. 
PUROLITE C.100H

CATION LEAKAGE CHARACTERISTICS

Fiqure 7.

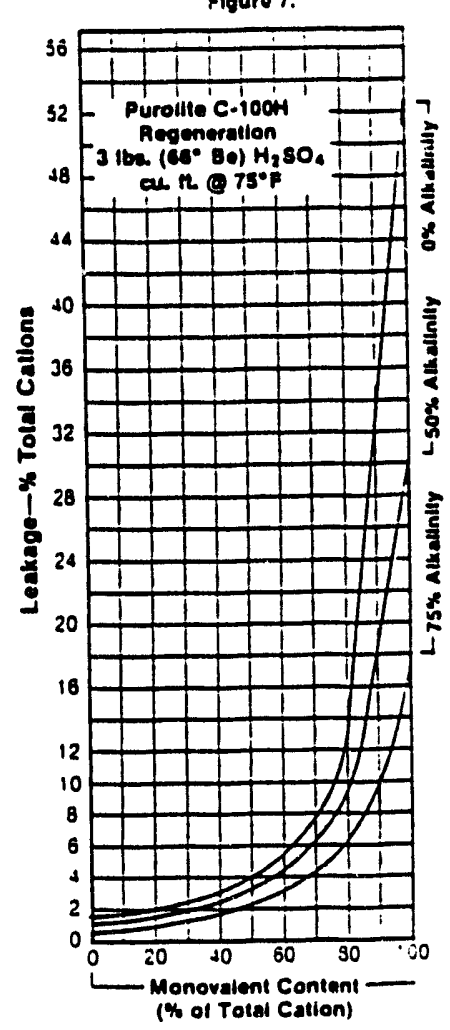

Flgure 10.

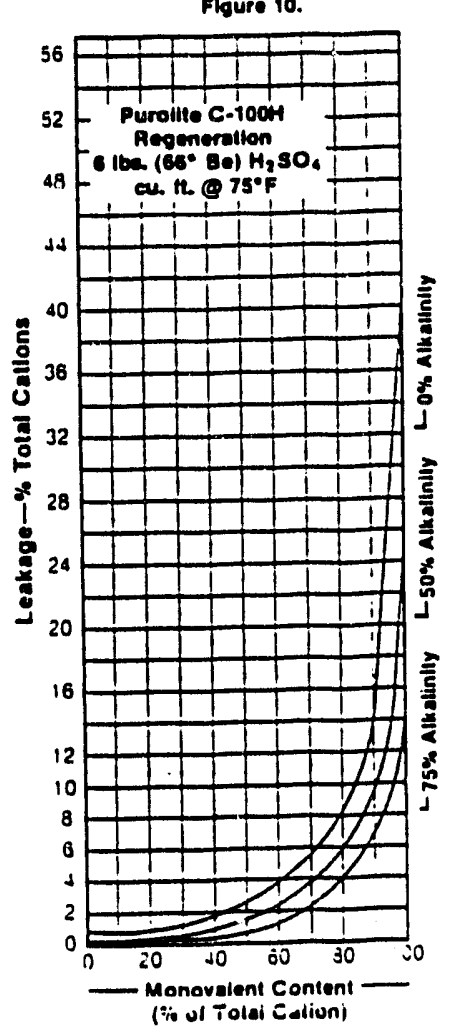

Fig̣ure 4.

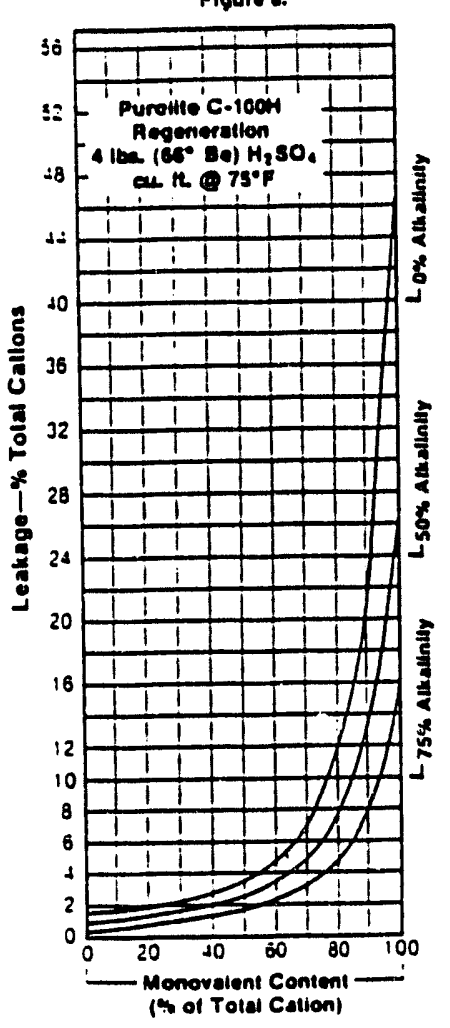

Figure 11.

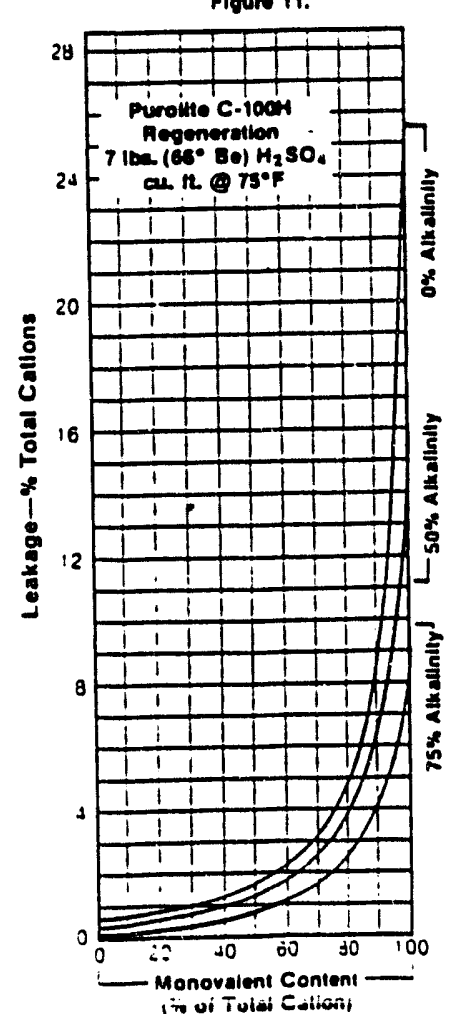

C-7
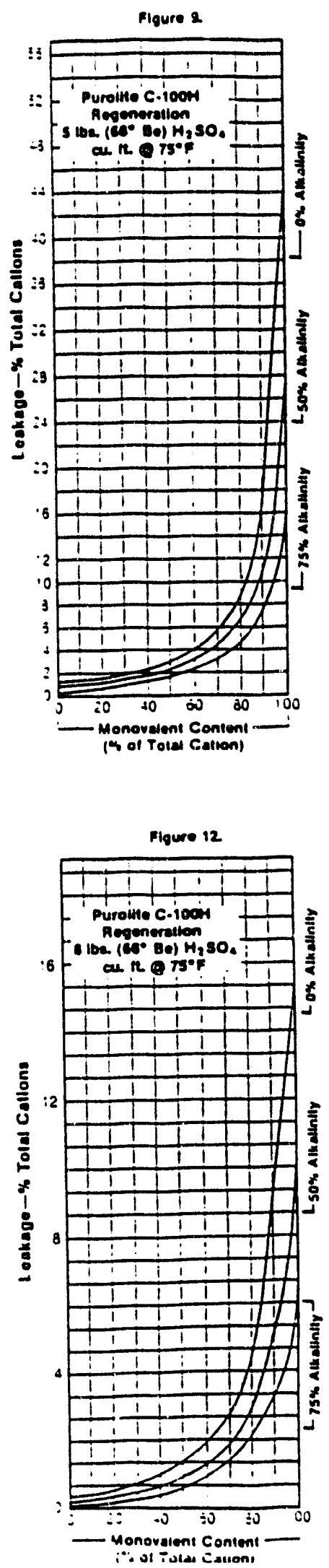


\section{Purolite C-100H \\ (Counter Current Regeneration)}

Operating Capacity-To End Point 500 ppb $\mathrm{Na}$

$\mathrm{H}_{2} \mathrm{SO}_{4}$ Regeneration-Stepwise-Counter Current

Figure 13

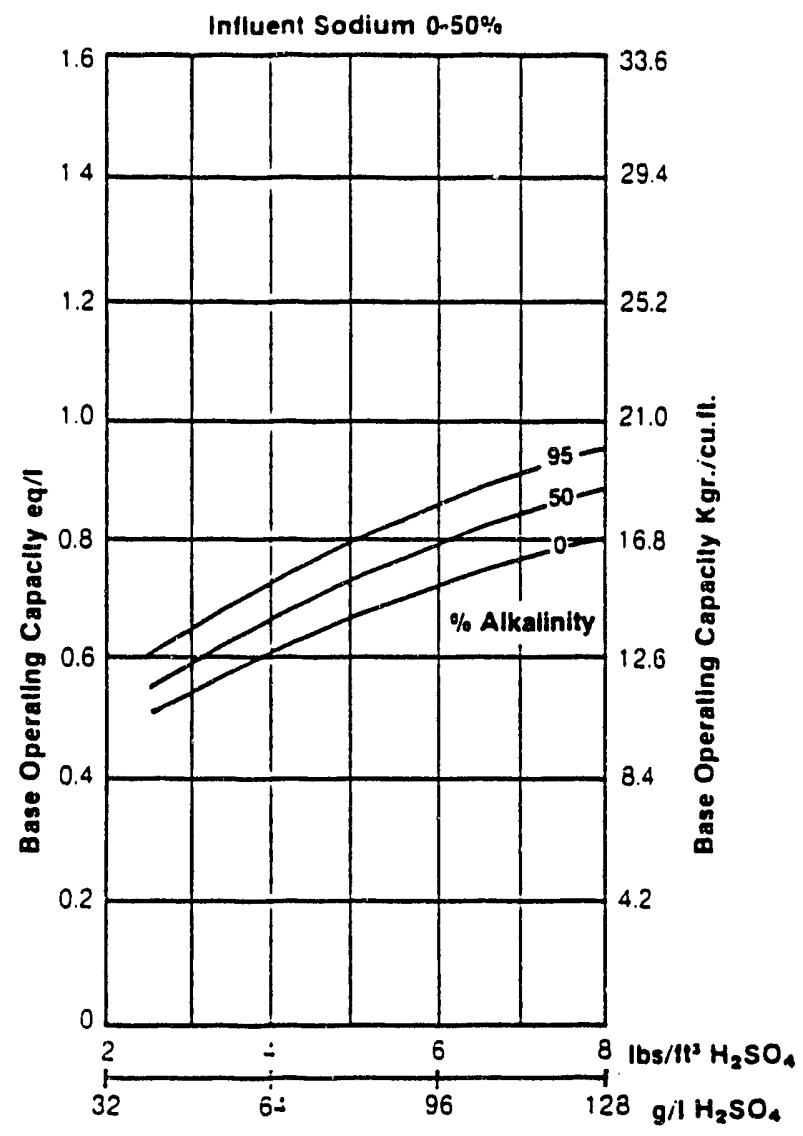

Figure 15

Leakage

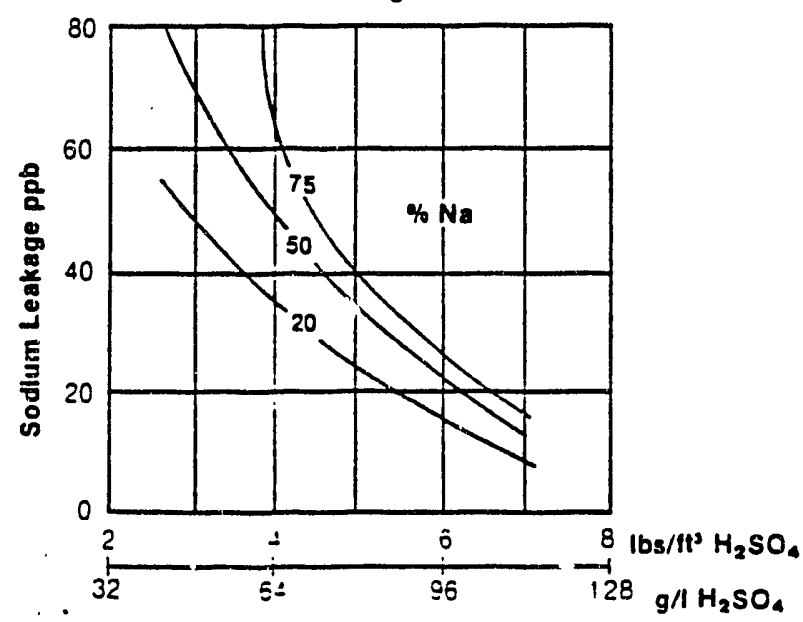

Figure 14

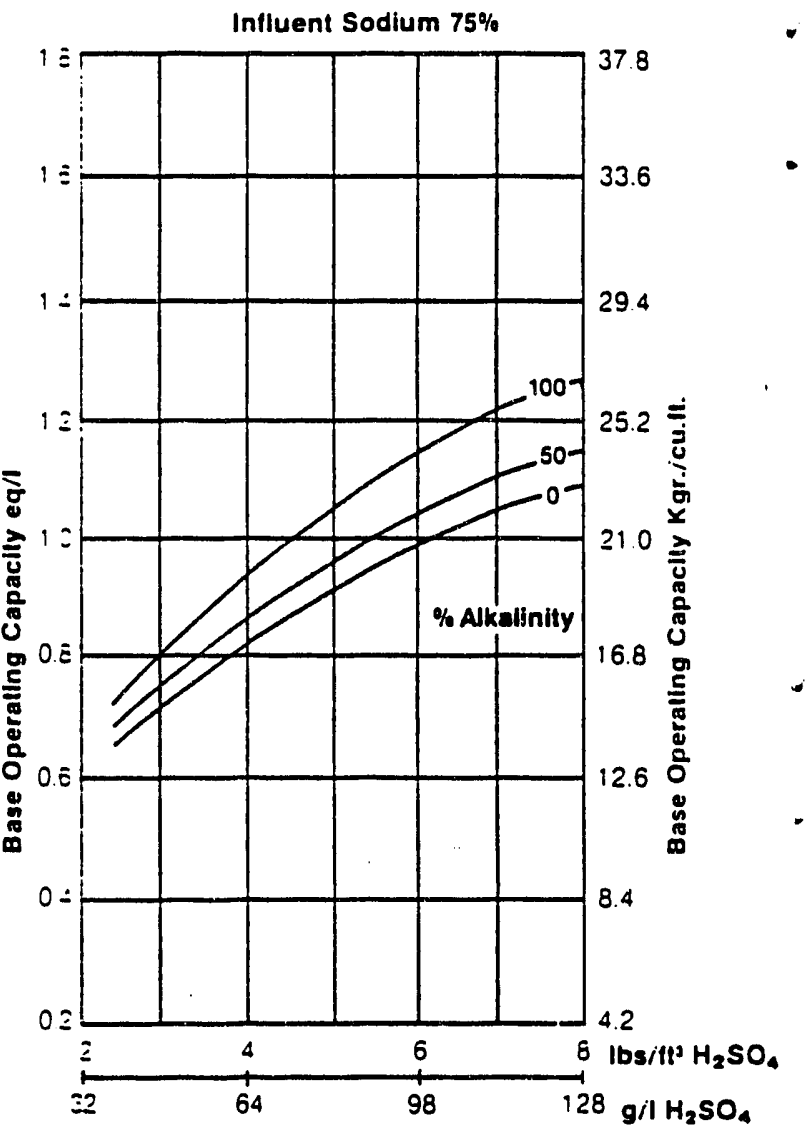

Figure 16

Capacify Correction for Water Temperature

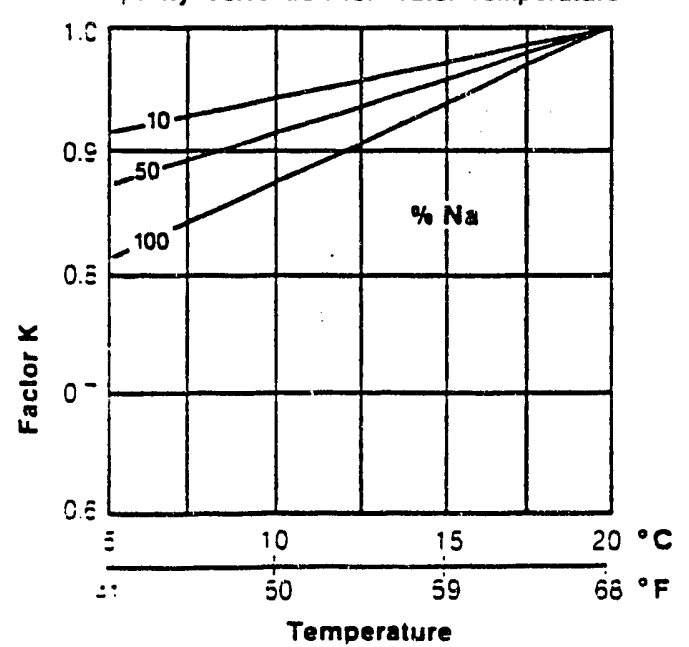


Purolite C-100H

(Counter Current Regeneration)

Operating Capacity-To End Point 500 ppb $\mathrm{Na}$

$\mathrm{HCl}$ Regeneration-Counter Current

Figure 17

Influent Sodium $0.50 \%$

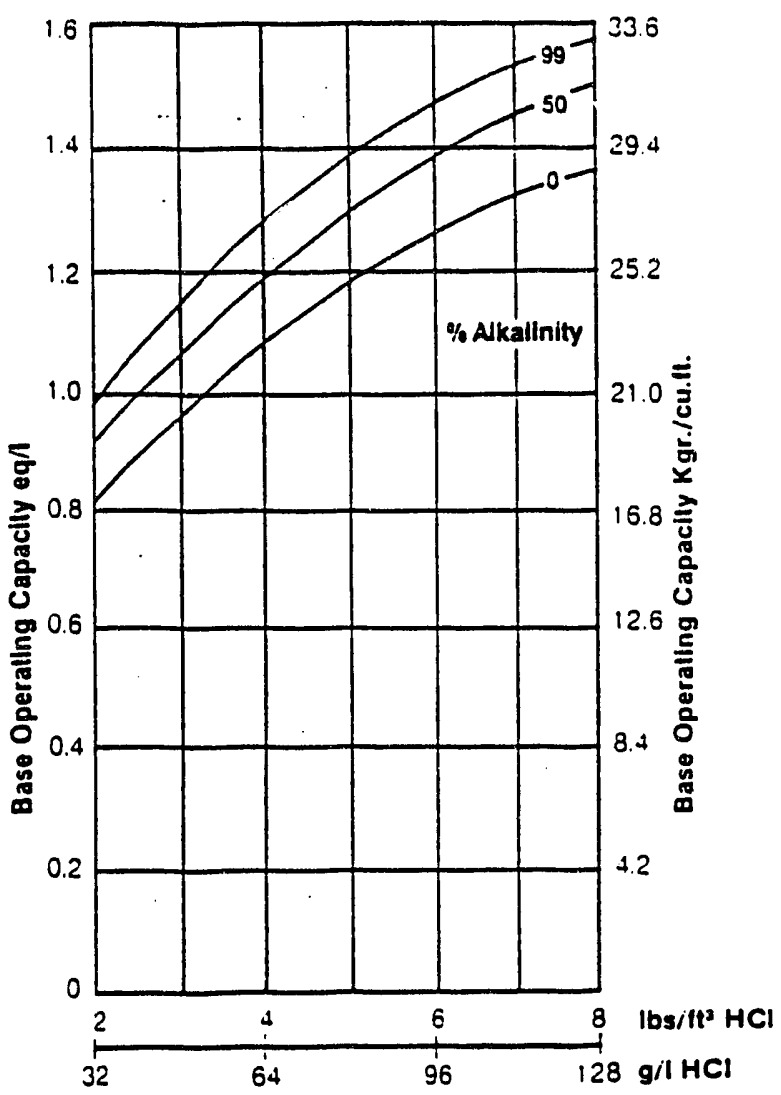

\section{Sodium Leakage}

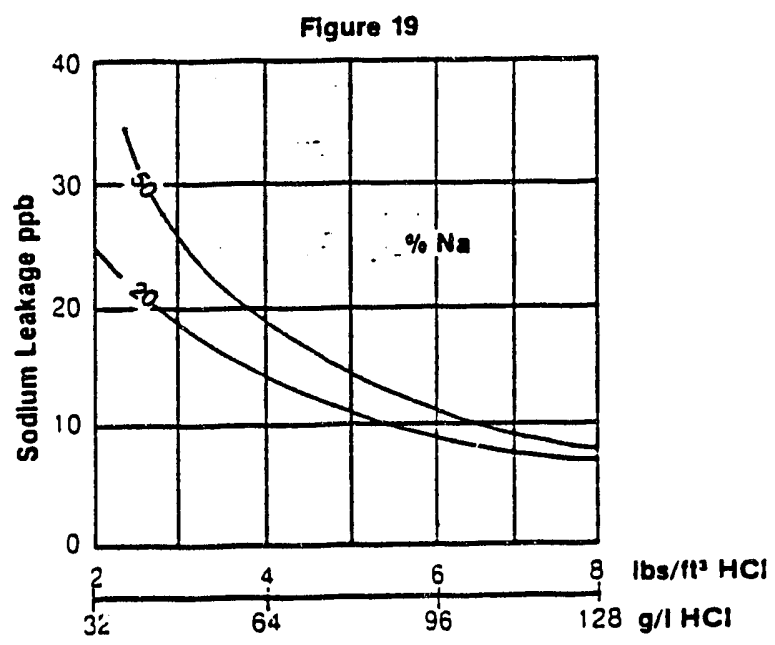

Figure 18

Influent Sodium $75 \%$

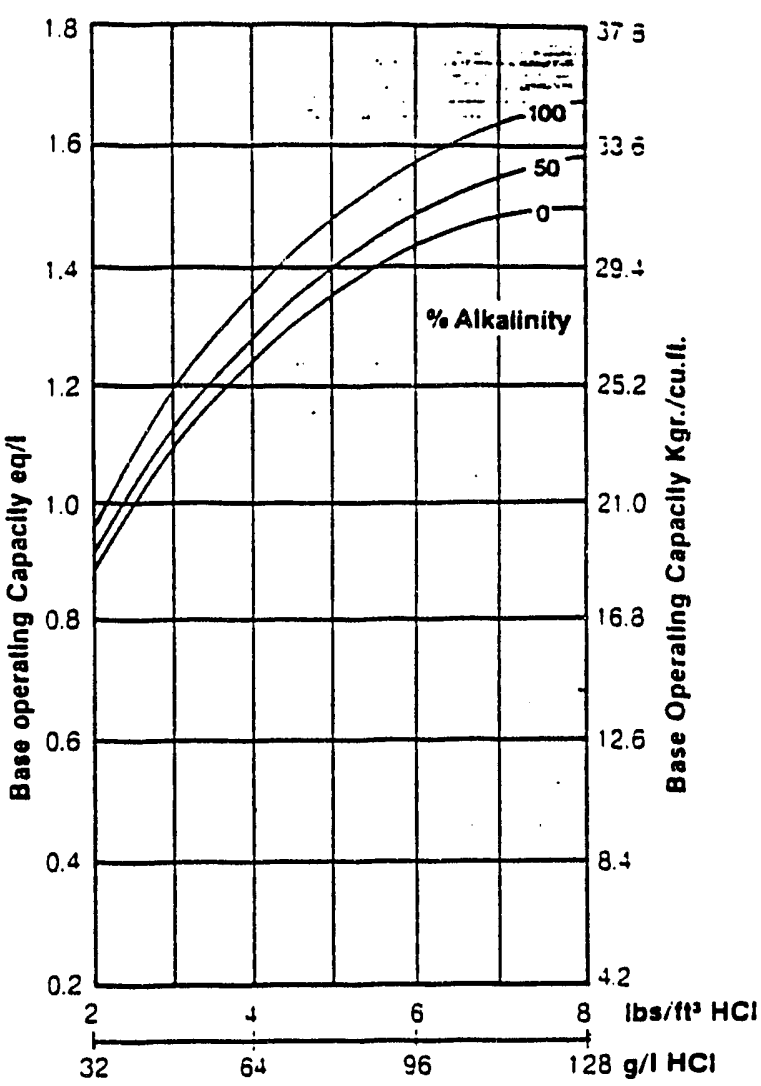

$28 \mathrm{~g} / \mathrm{l} \mathrm{HCl}$

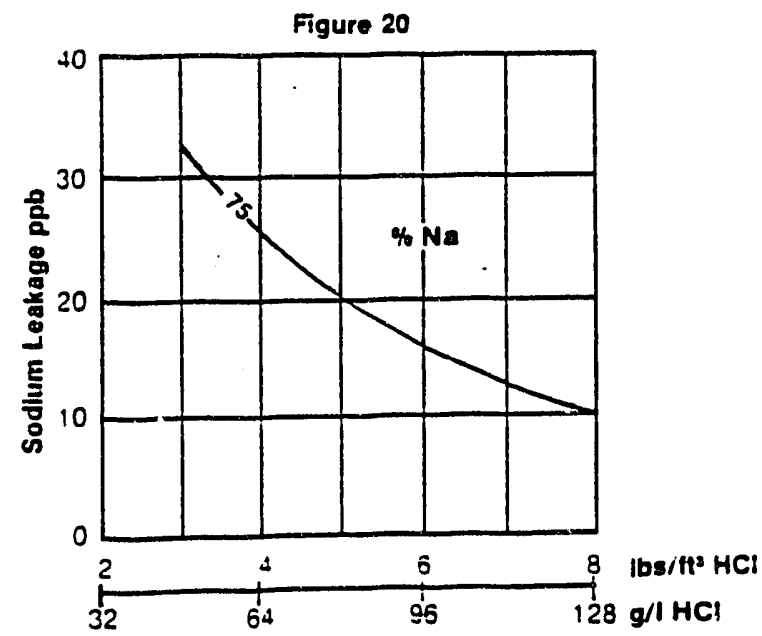


The Purolite Company and Purolite International Limited have one of the most complete lines of ion exchange resins worldwide. For more information call:

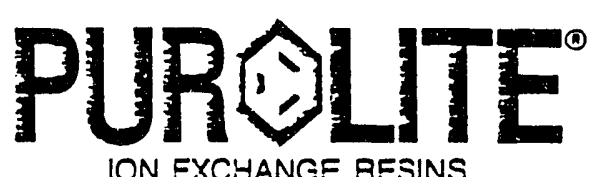

The Purolite Company and Purolite International Limited, Divisions of the Bro-Tech Corporation

\section{BUSINESS CENTERS AND SALES OFFICES:}

CANADA

The Purolite Company

107 George Street

Hamilton, Ontario L8P $1 E 3$

Telephone: $1-800-461-1500$

$1-416-528-4455$

Telex: 291718

Telefax: 1-416-528-5392

\section{GERMANY}

Purolite Deutschland GmbH

Harkort Strasse 25

4030 Ratingen

Telephone: $49-2102-46033$

Telex: 8589065

Telefax: $49-210-44-3633$

\section{ROMANIA}

Purolite Romania

Strada Plantclor Nr 61

Sector 2

Bucharest

Romania

Telephone: 400-22-3281

Telefax: $400-12-78-17$

\section{UNITED KINGDOM}

Purolite International Limited

Ashley House

89-94 High Street

Hounslow, UK TW31NH

Telephone: $44-081-570-4454$

Telex: 914030

Telefax: 44-081-572-7726

\section{FRANCE}

Purolite International Limited

44, Rue La Boétie

Paris 75008

Telephone: 33-14-256-4563

Telex: 648856

Telefax: 33-14-563-3826

ITALY

Purolite International S.R.L.

Viaje Coni Zugna, 29

Milan, 20144

Telephone: 39-2-481-8145

Telex: 335827

Telefax: 39-2-4801-2359

\section{U.S.A.}

The Purolite Company

150 Monument Road

Bala Cynwyd, PA 19004

Telephone: $1-800-343-1500$

$1-215-668-9090$

Telex: 291718

Telefax: 1-215-668-8139

\section{UNITED KINGDOM}

Purolite International Limited

Cowbridge Road, Pontyclun,

Mid Glamorgan, Wales,

CF78YL

Telephone: $44-443-229-334$

Telex: 498440

Telefax: 44-443-222-336

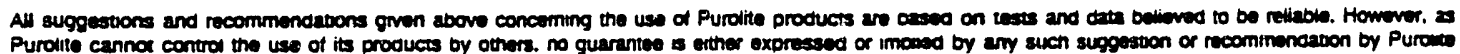
nor ts amy intormation contained in this leaftet to be construed as a recommondation to intringe any patemt currently valid. 


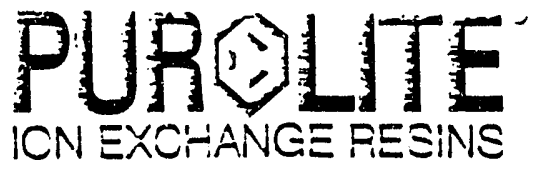

\section{S-920 \\ Macroporous Thiouronium Chelating Resin}

(For the selective removal of mercury and precious merais from aqueous solutions!

\section{Technical Data}

Section III.

Purolite S-920 is a macroporous polystyrenic based chelating resin, with thiouronium groups designed for the selective removal of mercury and for the recovery of precious metals from the industrial effluents. The mercury, in particular, is strongly bound to the functional groups to form highly stable complexes, with high selective affinity compared with those of other heavy metals. These properties are largely unaffected by high chloride (or sulphate) content of the effluent. Effluent solutions which may typically contain 2-20ppm of mercury can be treated to reduce the concentration in solution to less than 0.005 ppm. Purolite $\mathbf{S}-\mathbf{9 2 0}$ can load up to $150 \mathrm{~g}$ or mercury, or gold, or $60 \mathrm{~g}$ approx. of platinum or palladium for each litre of resin, equivalent io 9.4 , and $3.75 \mathrm{lb} / \mathrm{ft}^{3}$ respectively. Purolite S-920 is designed for the removal of low concentrations of soluble mercury salts from waste streams and for the recovery of precious metals from rinse waters in the galvanic and electronic industries. Purolite S-920 is also used in hydrometallurgy for the separation of precious metals from acid liquors. Mercury and precious metals are so strongly held, and run lengths are so long (thousands of hours) that it is not normally considered economic to regenerate the resin for reuse, hence the resin is burnt to recover the loaded metals.

Purolite S.920 is more resistant to oxidation than many thiol based resins and contact with the atmosphere is not detrimental, however free chlorine and other strong oxidising agents may damage the resin and their removal from solution by filtering through activated carbon is recommended.

\section{Typical Chemical \& Physical Characteristics}

Polymer Matrix Structure Macroporous Styrene-divinylbenzene

Physical form \& Appearance Opaque Cream Spheres

Whole Bead Count $>95 \%$

Functional Groups Thiouronium lonic Form (as shipped) $\mathrm{H}^{+}$

Shipping Weight $740 \mathrm{~g} / \mathrm{l}\left(46 \mathrm{lb} / \mathrm{ft}^{3}\right)$

Screen Size Range (British Standard Screen) 14-52 mesh, wet

Particle Size range $\%,-0.3 \mathrm{~mm}<1 \%$ Moisture-Retention, $\mathrm{H}+$ Form $48-54 \%$

Reversible Swelling, $\left(\mathrm{H}^{+} \rightarrow \mathrm{Hg}^{++}\right)$ $<5 \%$

Specific Gravity, Moist $\mathrm{H}^{+}$Form

Specific Gravity, Moist $\mathrm{Hg}^{++}$Form

Totai Exchange Capacity, $\mathrm{H}+$ Form (wet, volumetric)

Max, Operating Temperature, $H+$ Form $80^{\circ} \mathrm{C}\left(176^{\circ} \mathrm{F}\right)$ Operating $\mathrm{pH}$ Range 


\section{STANDARD OPERATING CONDITIONS}

It is recommended that Purolite $\mathbf{S - 9 2 0}$ is used in a two column, lead and trail system. In this way, maximum loading of the resin is achieved. When use is for mercury uptake, it is usual to pretreat the solution with lime

Recommended linear flow rate: Minimum bed depth: Backwash flow rate: neutralisa: on and to fully oxidise the metals and sulphites with $\mathrm{H}_{2} \mathrm{O}_{2}$. This is followed by flocculation with an inorganic polyelectrolite, sedimentesion, sand and activated carbon filtration.

$6-18 \mathrm{~m} / \mathrm{h}$ $1000 \mathrm{~mm}$

$4-8 \mathrm{~m} / \mathrm{h}$ (see fig. 2), for $20 \mathrm{~min}$.

\section{PRINCIPLE OF REACTION}

Mercury Removal<smiles>[R]CSC(N)[18O][Cl+][CH]C</smiles>

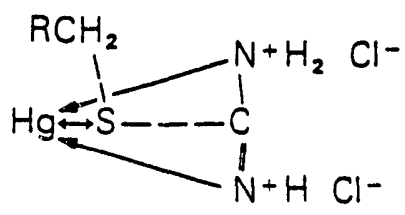

The mercury is strongly complexed by the sulphur and nitrogen groups. When the resin is well rinsed with water before use, the mercury salt as a whole is accommodated on the resin. In most instances the $\mathrm{pH}$ of the water to be treated will lie in the range of $3-10$, which is generally very suitable for highest mercury uptake. $\mathrm{pH}$ may be reduced slightly by the mercury exchange (release of acid held by ine weakly basic thiouronium groups).

In general Purolite S-920 will complex precious metals when they are present as free cations. The free cation state is governed bv the $\mathrm{pH}$ of the solution.

\section{HYDRAULIC CHARACTERISTICS}

The pressure drop (or headloss) across a properly classified bed of ion-exchange resin depends on the particle size distribution, bed depth, and voids volume of the exchange material, and on the flowrate and viscosity (and hence on the temperature) of the influent solution. Anything affecting any of these parameters, for example the presence of a particulate matter filtered out bv the bed, abnnomal comnarenn ni the rocin hor or the incomplete classification of the bed will have an aciverse effect, and result in an increased he dloss.

Service flo:: rates from $10-30$ bed volumes per hour, $c=2 e n d i n g$ on the application, may be regardez $\equiv s$ the normal range used on this resir. Typ: $=$ : pressure droo figures io be expecied fo: z-dinary aqueous solution, are niver in $=1-1$ 


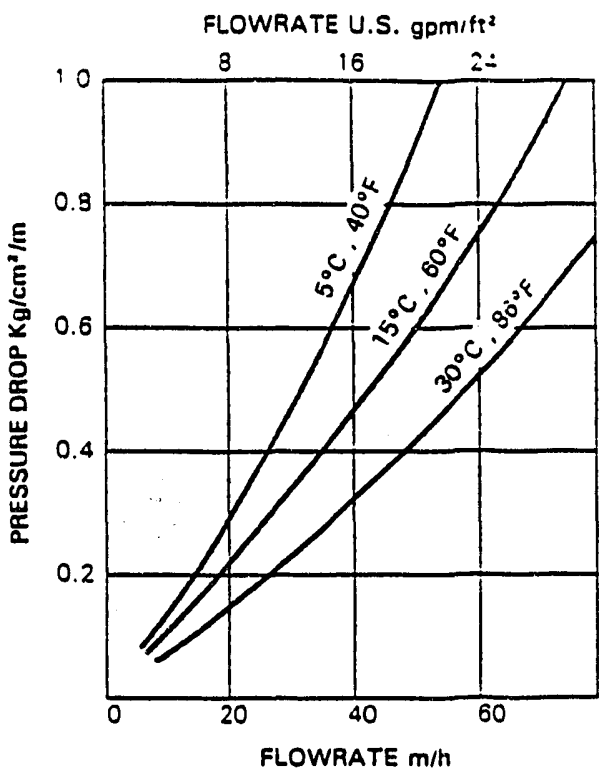

During upflow backwash, the resin bed should be expanded in volume by between 50 and $75 \%$, to clear the bed of bubiles and voids, and to classify the resin particles as much as possible, ensuring minimum resistance to flow. Bed expansion increases

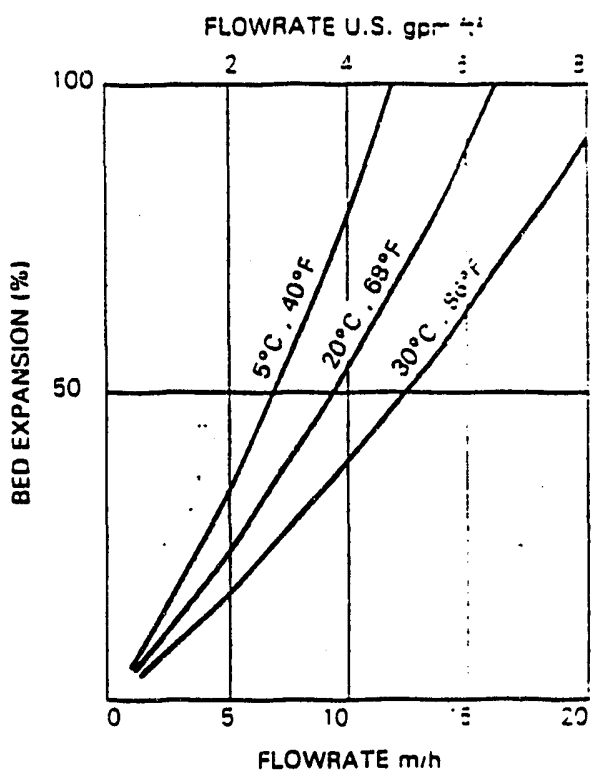

with flow rate and dec:eases with temperature, as shown in Fig. 2. This applies to unused resin. Since the resin is not regenerated, backwash at exhaustion is not required. Care should always se taken to avoid resin loss by over-expansion of the bed.

\section{CONVERSION OF UNITS}

$1 \mathrm{~m} / \mathrm{h}$ (cubic metres per square metre per hour)

$1 \mathrm{Kg} / \mathrm{cm}^{2} / \mathrm{m}$ (Kilograms per square $\mathrm{cm}$. per metre of bed)

$$
\begin{array}{ll}
=0.341 & \text { gpm. } / \mathrm{ft}^{2} . \\
=0.409 & \text { U.S.gpm. } / \mathrm{ft}^{2} .
\end{array}
$$

$$
\begin{aligned}
& =4.33 \mathrm{psi} / \mathrm{i} \\
& =1.03 \text { atm..'m. } \\
& =10 \quad \mathrm{ft} . \mathrm{H}_{2} \mathrm{O} / \mathrm{ft} \text {. }
\end{aligned}
$$

\section{OPERATING PERFORMANCE}

The operating capacity will be higner on the first cycle since both lead and traii columns will use new resin. This cycle wiil be complete when the lead column is saturated (that is when influent and effluent have reached equilibrium). The substantial leakage which occurs from the lead column towarcs the end of the cycle is of course taken CL: $z y$ the trail coll.mn. This uses capacity depersing upon the sonditions of operation. In sursequent -iss the throughput obtained ticm :he !ead column will be reduced acccraing to load previously taken up while the $c=d$ was in the trail position.

The Fig. 3. gives a typical exhaustion profile from the outlet of the trail coivinn in ierms of bed volumes throughput for ine lead column. In a typical operation as s-s:vn the !ead column is loaded with a total oi $\mathrm{O}$ ggll or mercury of which $70-85 \mathrm{~g} / /$ may $b$ saded sinile the bes in in the lead positio- 
Fig. 3. OPERATING PROFILE: Typical from trail column

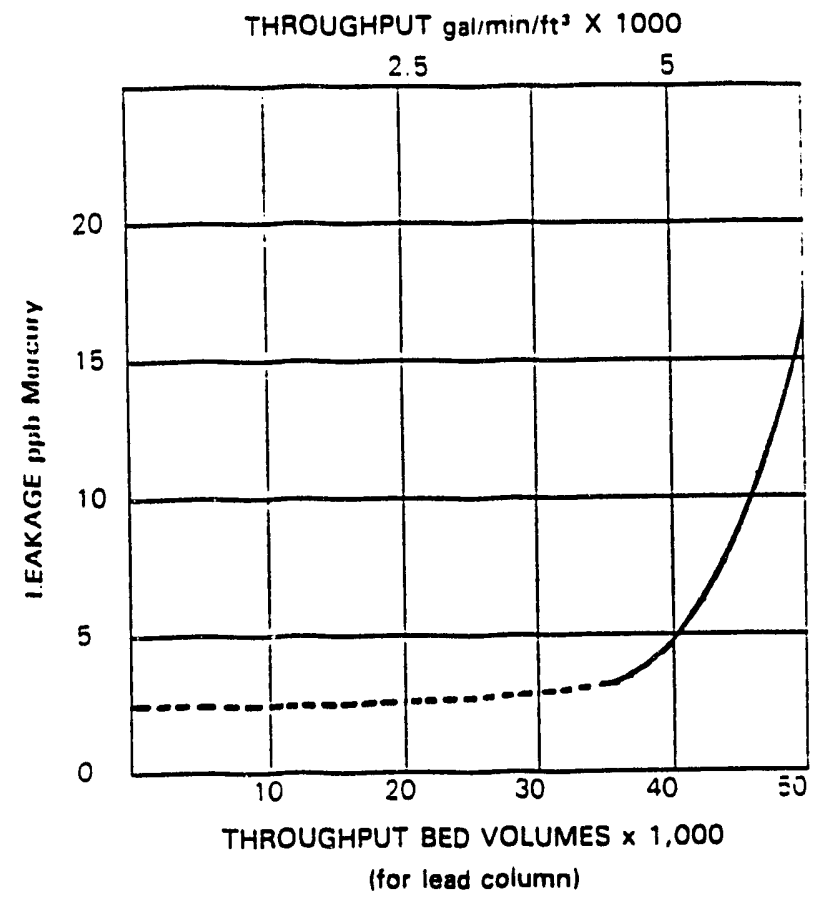

Inlet Mercury - 2ppm to Lead Column Temperature $20^{\circ} \mathrm{C}$ $\mathrm{pH}$ 8.0 Fiow Rate $8 B V / h$ (for lead column) 
Appendix D

RML Radiochemistry Results

D-1 
SAMPLE ID KEY

\begin{tabular}{|c|c|c|c|}
\hline EGG SAMPLE NUMBER & SAMPLE SOURCE & $\begin{array}{l}\text { ANALYSIS } \\
\text { PERFORMED } \\
\end{array}$ & DATE \\
\hline PWTUF ILE8CLR & CONSOLIDATED LIQUIDS & $\begin{array}{l}\text { (RML) } \\
\text { RADIOCHEMISTRY } \\
\end{array}$ & $9 / 10 / 92$ \\
\hline PWTUF ILEBCLT & CONSOLIDATED LIQUIDS & (TCT) FULL TCLP & $9 / 10 / 92$ \\
\hline PWTUF ILEBCLTBI & TRIP BLANK & (TCT) TCLP VOA & $9 / 10 / 92$ \\
\hline PWTUFILE8CLTB2 & TRIP BLANK & (TCT) TCLP VOA & $9 / 10 / 92$ \\
\hline PWTUF ILE8TLS1 & $\begin{array}{l}\text { TRIAL } 1 \text { TREATED LIQUID } \\
\text { TANK } 1\end{array}$ & $\begin{array}{l}\text { (ECU) FULL METALS } \\
\text { SCREENING }\end{array}$ & 9/15/92 \\
\hline PWTUFILE8TLS2 & $\begin{array}{l}\text { TRIAL } 1 \text { TREATED LIQUID } \\
\text { TANK } 2\end{array}$ & $\begin{array}{l}\text { (ECU) FULL METALS } \\
\text { SCREENING }\end{array}$ & $9 / 15 / 92$ \\
\hline PWTUF ILE8TLTI & $\begin{array}{l}\text { TRIAL } 1 \text { TREATED LIQUID } \\
\text { TANK } 1\end{array}$ & $\begin{array}{l}\text { (TCT) TCLP } \\
\text { METALS, SEMI -VOA, } \\
\text { PESTICIDES, AND } \\
\text { HERBICIDES }\end{array}$ & $9 / 16 / 92$ \\
\hline PWTUF ILE8TLT2 & $\begin{array}{l}\text { TRIAL } 1 \text { TREATED LIQUID } \\
\text { TANK } 2\end{array}$ & $\begin{array}{l}\text { (TCT) TCLP } \\
\text { METALS, SEMI-VOA, } \\
\text { PESTICIDES, AND } \\
\text { HERBICIDES }\end{array}$ & $9 / 16 / 92$ \\
\hline PWTUFILE8TLVI & $\begin{array}{l}\text { TRIAL } 1 \text { TREATED LIQUID } \\
\text { TANK } 1\end{array}$ & (TCT) TCLP VOA & $9 / 16 / 92$ \\
\hline PWTUFILE8TLV2 & $\begin{array}{l}\text { TRIAL } 1 \text { TREATED LIQUID } \\
\text { TANK } 2\end{array}$ & (TCT) TCLP VOA & $9 / 16 / 92$ \\
\hline PWTUFILE8TLTB3 & TRIP BLANK & (TCT) TCLP VOA & $9 / 16 / 92$ \\
\hline PWTUTW1T & $\begin{array}{l}\text { TRIAL } 2 \text { TREATED LIQUID } \\
\text { TANK } 1\end{array}$ & $\begin{array}{l}\text { (TCT) TCLP } \\
\text { METALS, SEMI -VOA, } \\
\text { PESTICIDES, AND } \\
\text { HERBICIDES } \\
\end{array}$ & $9 / 30 / 92$ \\
\hline PWTUTW2T & $\begin{array}{l}\text { TRIAL } 2 \text { TREATED LIQUID } \\
\text { TANK } 2\end{array}$ & $\begin{array}{l}\text { (TCT) TCLP } \\
\text { METALS, SEMI -VOA, } \\
\text { PESTICIDES, AND } \\
\text { HERBICIDES } \\
\end{array}$ & $9 / 30 / 92$ \\
\hline PWTUTW1V & $\begin{array}{l}\text { TRIAL } 2 \text { TREATED LIQUID } \\
\text { TANK } 1\end{array}$ & (TCT) TCLP VOA & 9/30/92 \\
\hline PWTUTW2V & $\begin{array}{l}\text { TRIAL } 2 \text { TREATED LIQUID } \\
\text { TANK } 2\end{array}$ & (TCT) TCLP VOA & $9 / 30 / 92$ \\
\hline PUTUTWTB & TRIP BLANK & (TCT) TCLP YOA & 9/30/92 \\
\hline
\end{tabular}




\begin{tabular}{|c|c|c|c|}
\hline EGG SAMPLE NUMBER & SAMPLE SOURCE & $\begin{array}{l}\text { ANALYSIS } \\
\text { PERFORMED } \\
\end{array}$ & DATE \\
\hline PWTUTLTWIM & $\begin{array}{l}\text { TRIAL } 2 \text { TREATED LIQUID } \\
\text { REANALYSIS TANK } 1 \\
\end{array}$ & $\begin{array}{l}\text { (TCT) TCLP } \\
\text { MERCURY ONLY }\end{array}$ & $10 / 6 / 92$ \\
\hline PWTUTLTW2M & $\begin{array}{l}\text { TRIAL } 2 \text { TREATED LIQUID } \\
\text { REANALYSIS TANK } 2\end{array}$ & $\begin{array}{l}\text { (TCT) TCLP } \\
\text { MERCURY ONLY } \\
\end{array}$ & $10 / 6 / 92$ \\
\hline PWTUTW12TSM & $\begin{array}{l}\text { TRIAL } 2 \text { TREATED LIQUID } \\
\text { REANALYSIS TANK } 1 \& 2 \text { MIX } \\
\end{array}$ & $\begin{array}{l}\text { (ECU) TCLP } \\
\text { MERCURY ONLY }\end{array}$ & $10 / 6 / 92$ \\
\hline PWTUTWF1TS & $\begin{array}{l}\text { TRIAL } 3 \text { TREATED LIQUID } \\
\text { TANK } 1\end{array}$ & $\begin{array}{l}\text { (ECU) TCLP } \\
\text { MERCURY ONLY } \\
\end{array}$ & $10 / 22 / 92$ \\
\hline PWTUTWF2TS & $\begin{array}{l}\text { TRIAL } 3 \text { TREATED LIQUID } \\
\text { TANK } 2\end{array}$ & $\begin{array}{l}\text { (ECU) TCLP } \\
\text { MERCURY ONLY }\end{array}$ & $10 / 22 / 92$ \\
\hline PWTUTWF IM & $\begin{array}{l}\text { TRIAL } 3 \text { TREATED LIQUID } \\
\text { TANK } 1\end{array}$ & $\begin{array}{l}\text { (TCT) TCLP } \\
\text { MERCURY ONLY }\end{array}$ & $10 / 22 / 92$ \\
\hline PWTUTWF2M & $\begin{array}{l}\text { TRIAL } 3 \text { TREATED LIQUID } \\
\text { TANK } 2\end{array}$ & $\begin{array}{l}\text { (TCT) TCLP } \\
\text { MERCURY ONLY } \\
\end{array}$ & $10 / 22 / 92$ \\
\hline PWTUTW1R & $\begin{array}{l}\text { TRIAL } 1 \text { TREATED LIQUID } \\
\text { TANK } 1\end{array}$ & $\begin{array}{l}\text { (RML) } \\
\text { RADIOCHEMISTRY } \\
\end{array}$ & $9 / 30 / 92$ \\
\hline PWTUTW2R1 & $\begin{array}{l}\text { TRIAL } 1 \text { TREATED LIQUID } \\
\text { TANK } 2\end{array}$ & $\begin{array}{l}\text { (RML) } \\
\text { RADIOCHEMISTRY } \\
\end{array}$ & $9 / 30 / 92$ \\
\hline PWTUTW2R2 & $\begin{array}{l}\text { TRIAL } 1 \text { TREATED LIQUID } \\
\text { TANK } 2\end{array}$ & $\begin{array}{l}\text { (RML) DUPLICATE } \\
\text { RADIOCHEMISTRY } \\
\end{array}$ & $9 / 30 / 92$ \\
\hline PWTUIOXRI & $\begin{array}{l}\text { ION EXCHANGE RESIN } \\
\text { CONSOLIDATED SAMPLE } 1 \\
\end{array}$ & $\begin{array}{l}\text { (RML) } \\
\text { RADIOCHEMISTRY } \\
\end{array}$ & $9 / 30 / 92$ \\
\hline PWTUIOXR2 & $\begin{array}{l}\text { ION EXCHANGE RESIN } \\
\text { CONSOLIDATED SAMPLE } 2\end{array}$ & $\begin{array}{l}\text { (RML) } \\
\text { RADIOCHEMISTRY }\end{array}$ & $9 / 30 / 92$ \\
\hline PWTUPFRI & $\begin{array}{l}\text { FILTERS CONSOLIDATED } \\
\text { SAMPLE } 1\end{array}$ & $\begin{array}{l}\text { (RML) } \\
\text { RADIOCHEMISTRY }\end{array}$ & $9 / 30 / 92$ \\
\hline PWTUPFR2 & $\begin{array}{l}\text { FILTERS CONSOLIDATED } \\
\text { SAMPLE } 2\end{array}$ & $\begin{array}{l}\text { (RML) } \\
\text { RADIOCHEMISTRY }\end{array}$ & $9 / 30 / 92$ \\
\hline PWTUIOXT1 & $\begin{array}{l}\text { ION EXCHANGE RESIN } \\
\text { CONSOLIDATED SAMPLE } 1 \\
\end{array}$ & (TCT) FULL TCLP & $9 / 30 / 92$ \\
\hline PWTUIOXT2 & $\begin{array}{l}\text { ION EXCHANGE RESIN } \\
\text { CONSOLIDATED SAMPLE } 2\end{array}$ & (TCT) FULL TCLP & $9 / 30 / 92$ \\
\hline PWTUIOXC1 & $\begin{array}{l}\text { ION EXCHANGE RESIN } \\
\text { CONSOLIDATED SAMPLE I } \\
\end{array}$ & (TCT) CORROSIVITY & $9 / 30 / 92$ \\
\hline
\end{tabular}




\begin{tabular}{||l|l|l|l||}
\hline EGG SAMPLE NUMBER & SAMPLE SOURCE & $\begin{array}{l}\text { ANALYSIS } \\
\text { PERFORMED }\end{array}$ & DATE \\
\hline \hline PWTUIOXC2 & $\begin{array}{l}\text { ION EXCHANGE RESIN } \\
\text { CONSOLIDATED SAMPLE 2 }\end{array}$ & (TCT) CORROSIVITY & $9 / 30 / 92$ \\
\hline PWTUPFT1 & $\begin{array}{l}\text { FILTERS CONSOLIDATED } \\
\text { SAMPLE 1 }\end{array}$ & (TCT) FULL TCLP & $9 / 30 / 92$ \\
\hline PWTUPFT2 & $\begin{array}{l}\text { FILTERS CONSOLIDATED } \\
\text { SAMPLE 2 }\end{array}$ & (TCT) FULL TCLP & $9 / 30 / 92$ \\
\hline PWTUPFC1 & $\begin{array}{l}\text { FILTERS CONSOLIDATED } \\
\text { SAMPLE 1 }\end{array}$ & (TCT) CORROSIVITY & $9 / 30 / 92$ \\
\hline PWTUPFC2 & $\begin{array}{l}\text { FILTERS CONSOLIDATED } \\
\text { SAMPLE 2 }\end{array}$ & (TCT) CORROSIVITY & $9 / 30 / 92$ \\
\hline
\end{tabular}



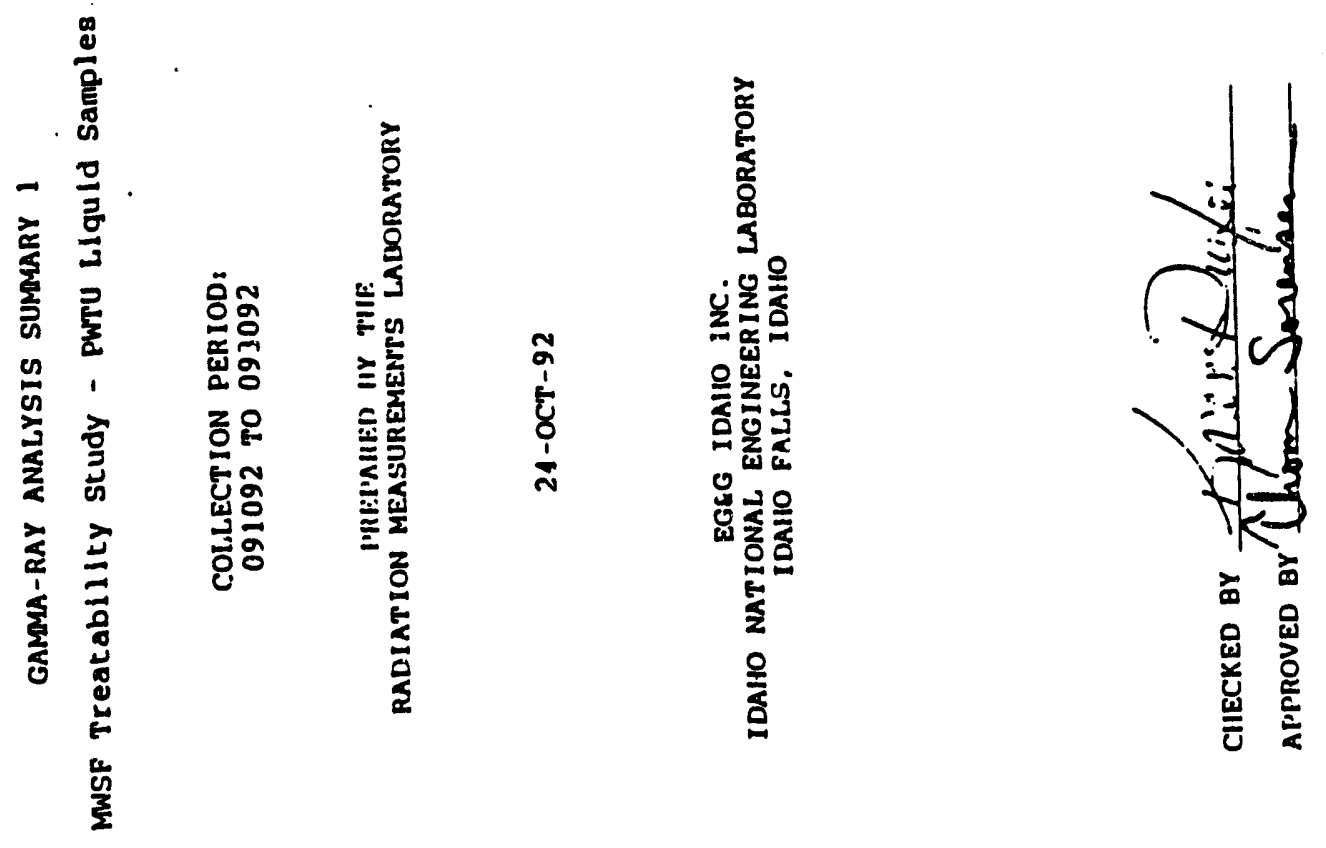

D-5 

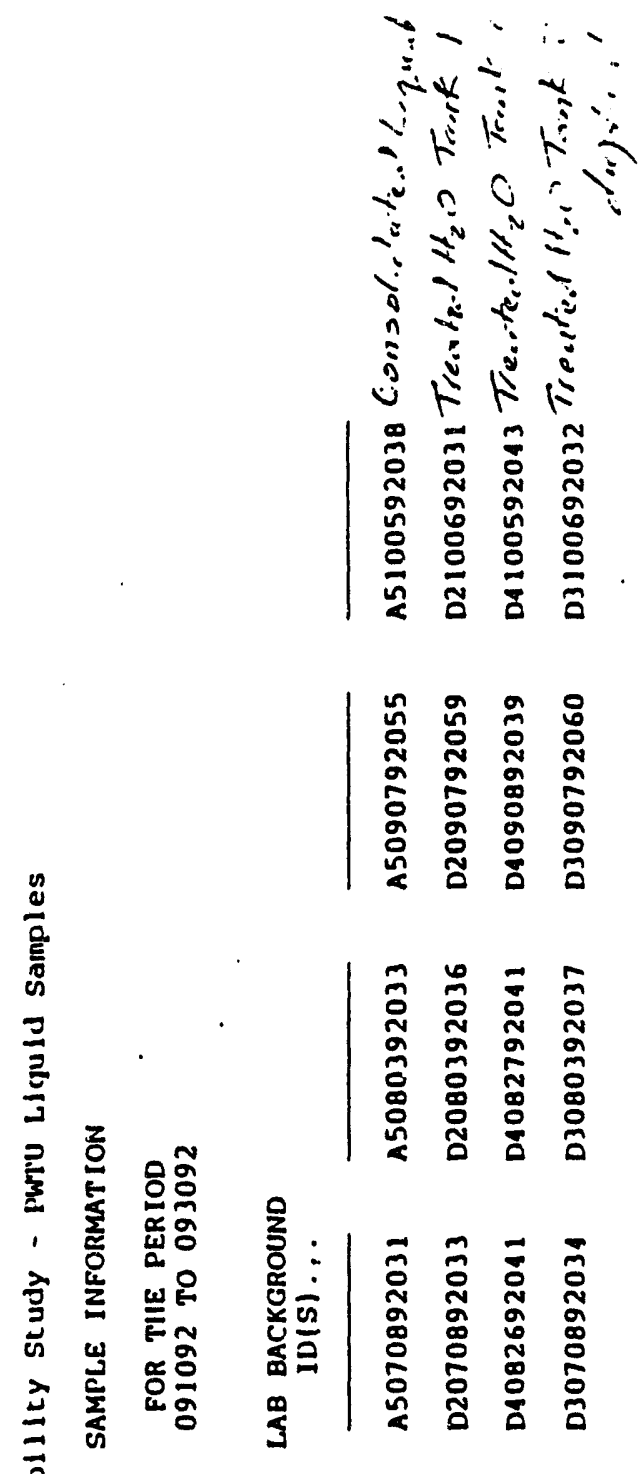

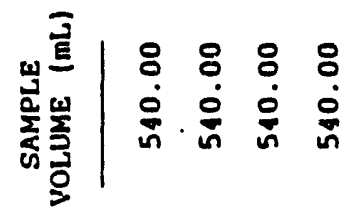

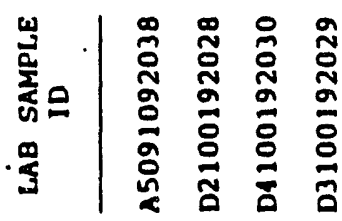

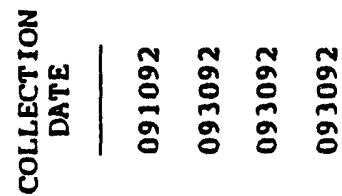

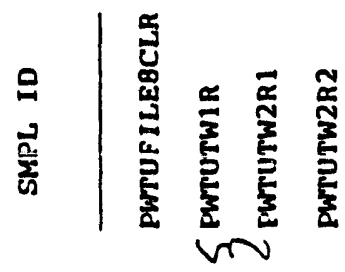

$x$
$\dot{x} .7$ 


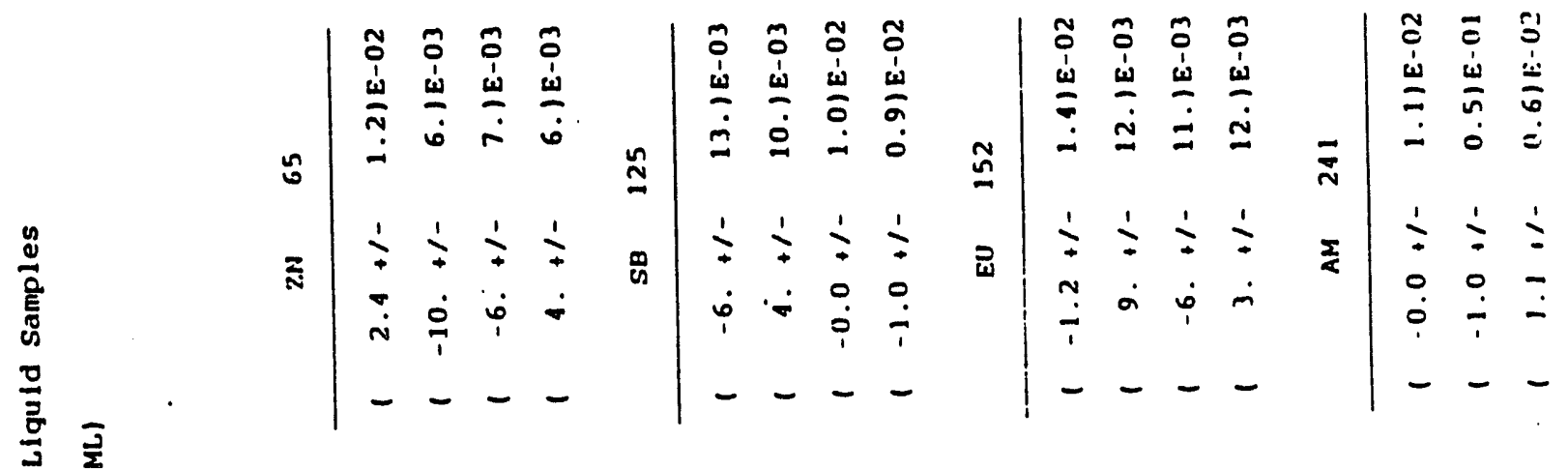

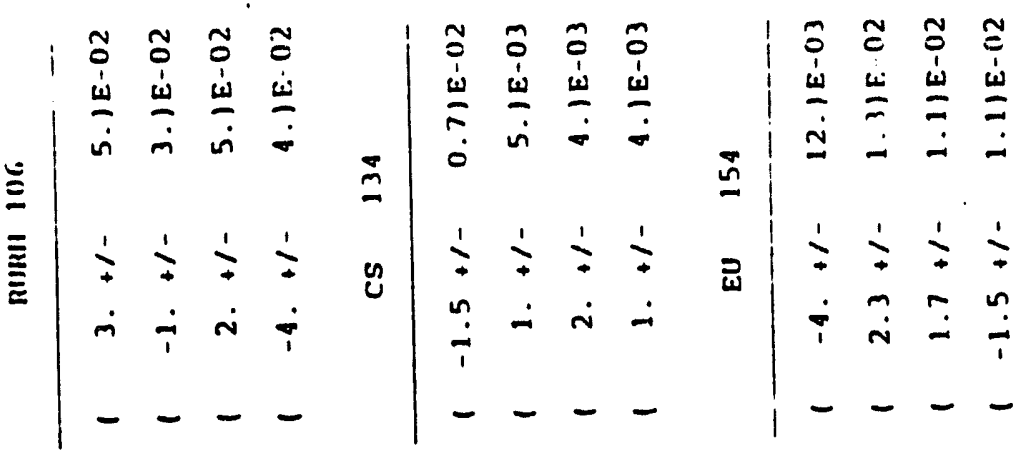

를 음월

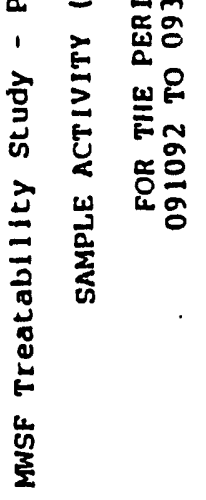

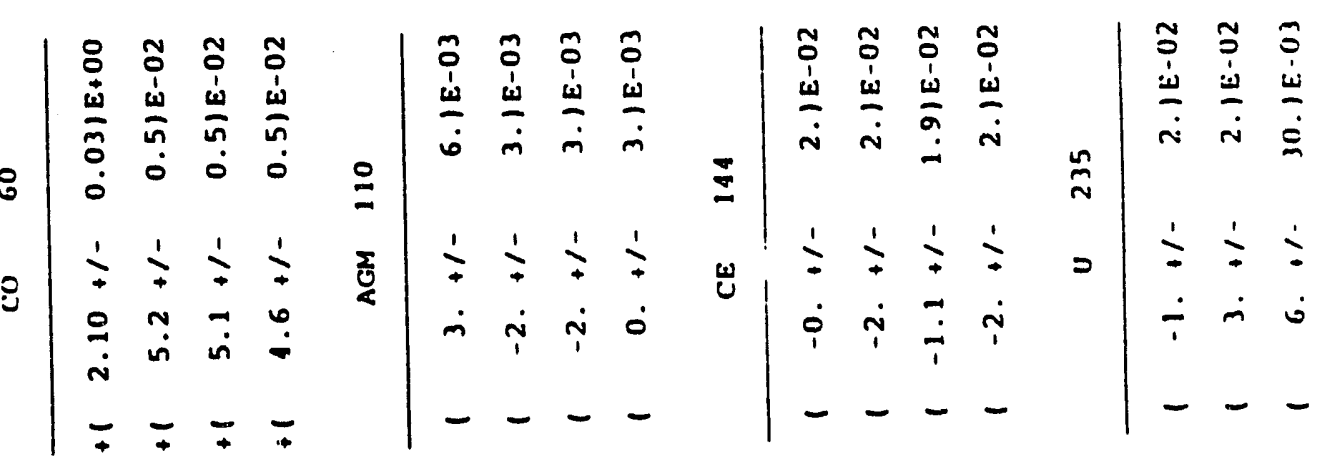

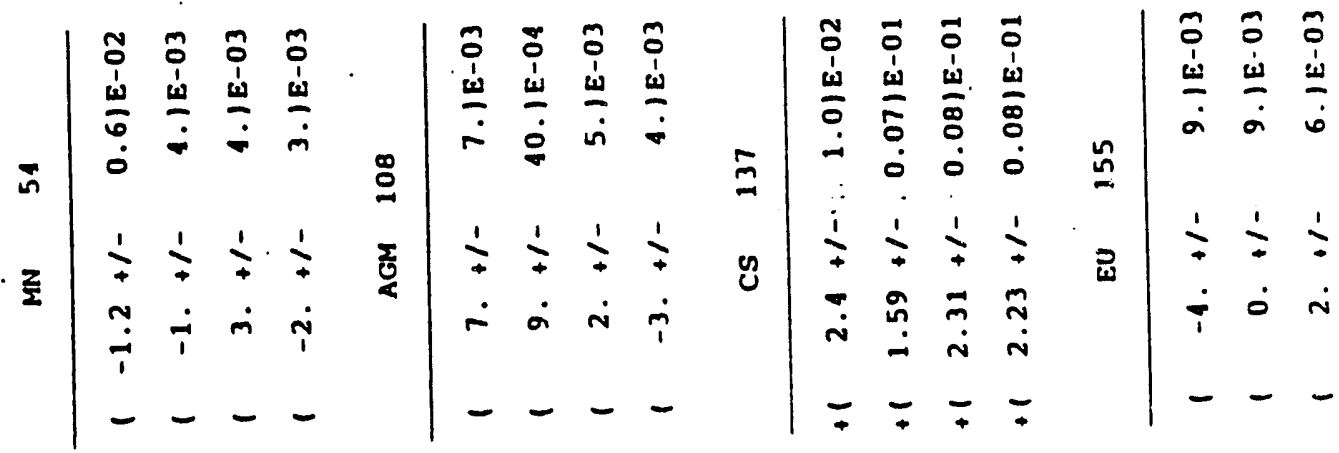

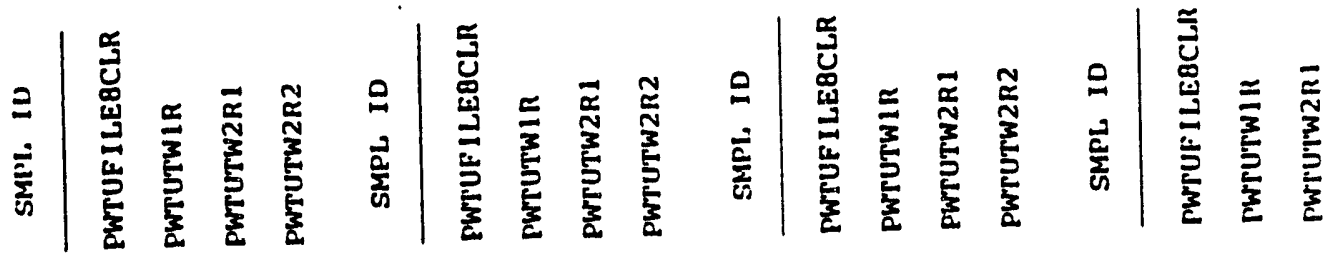




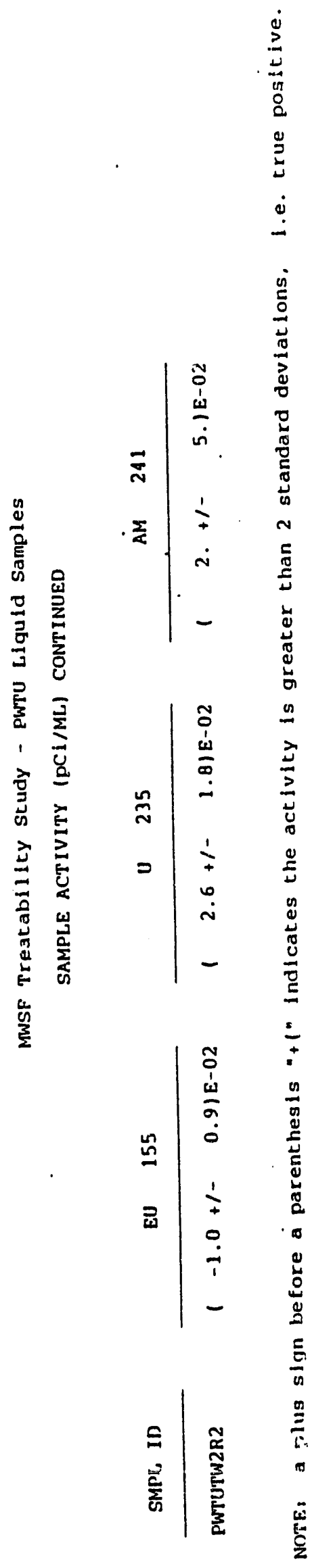

D-8 


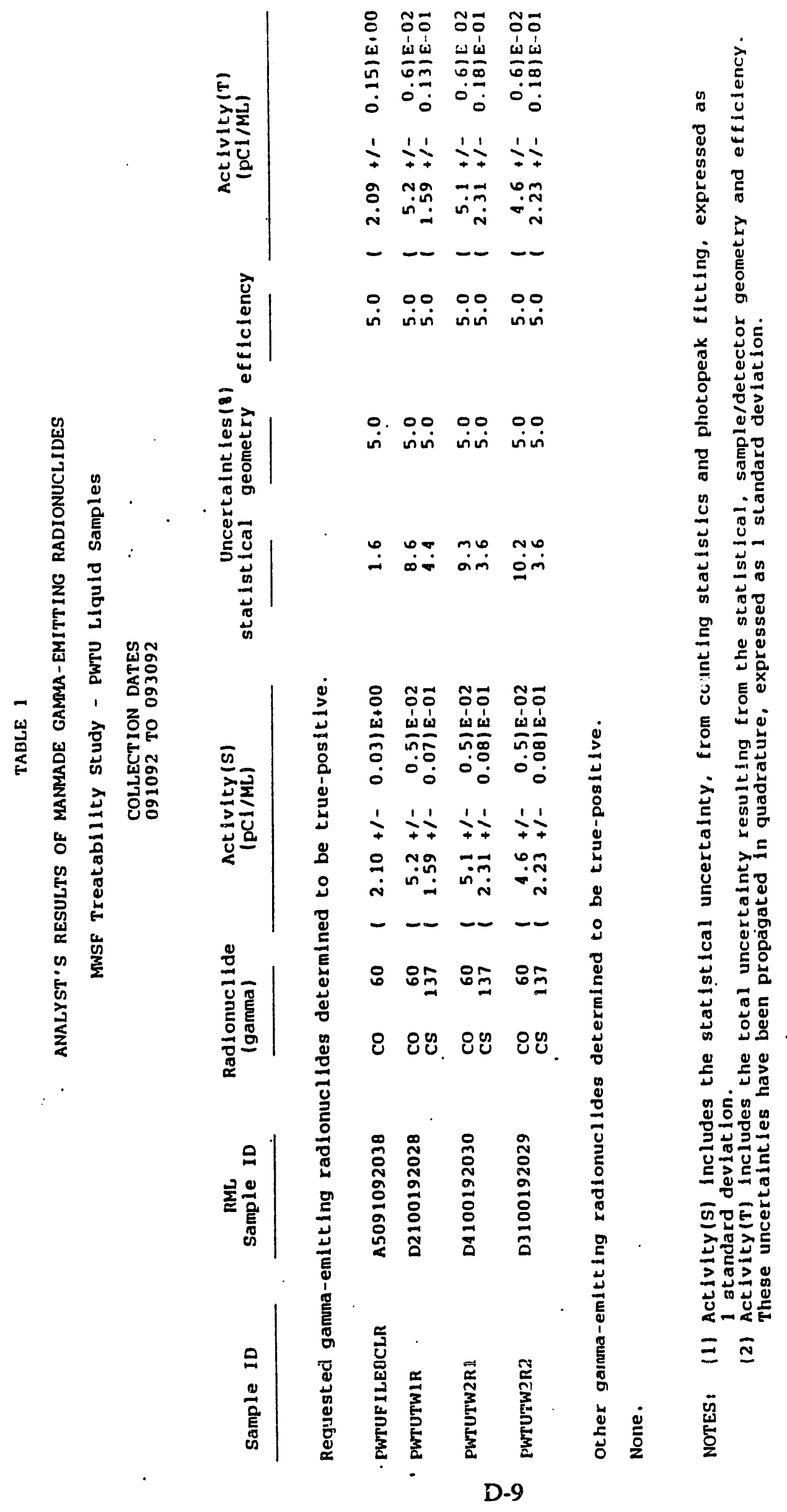




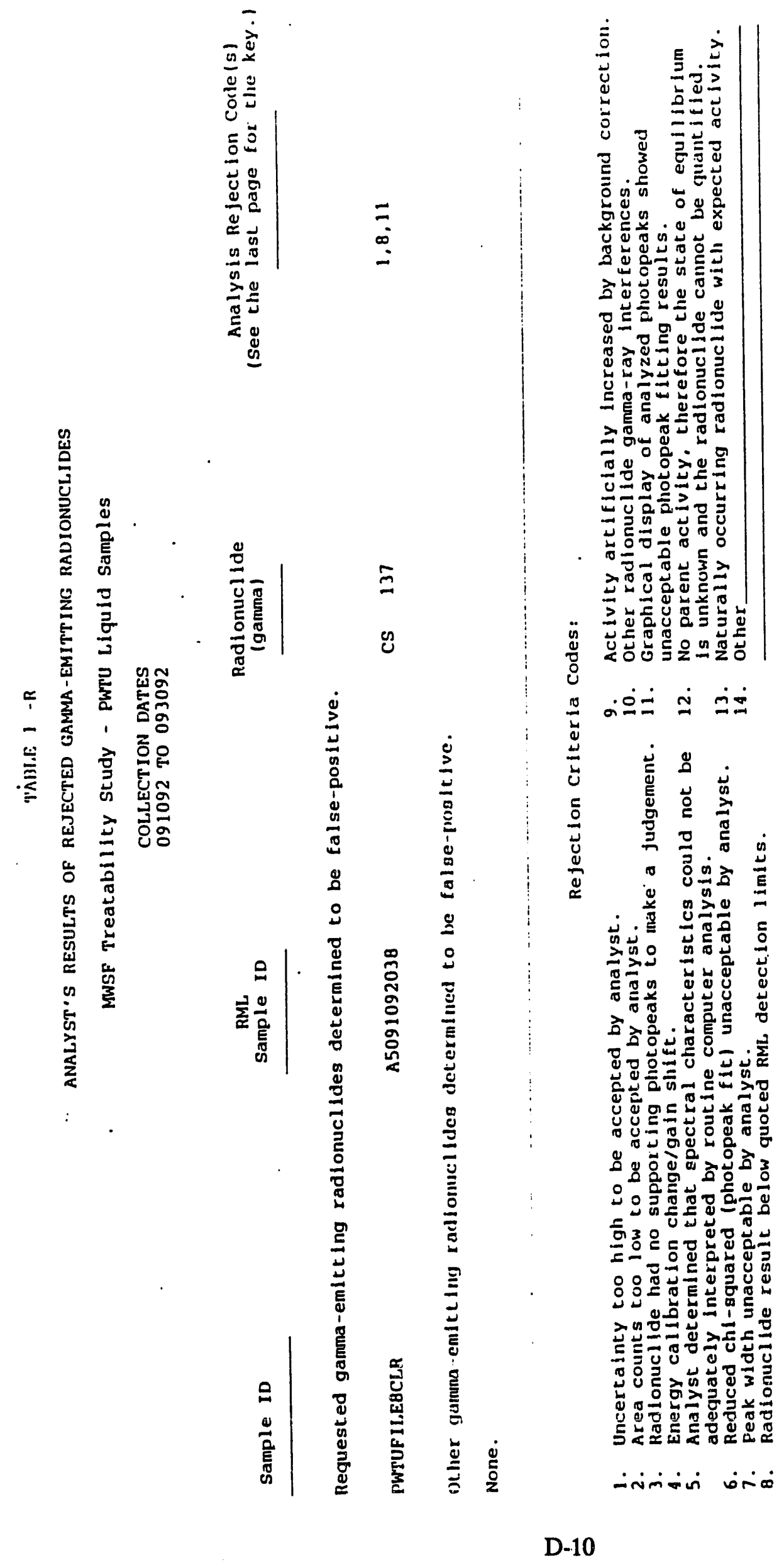



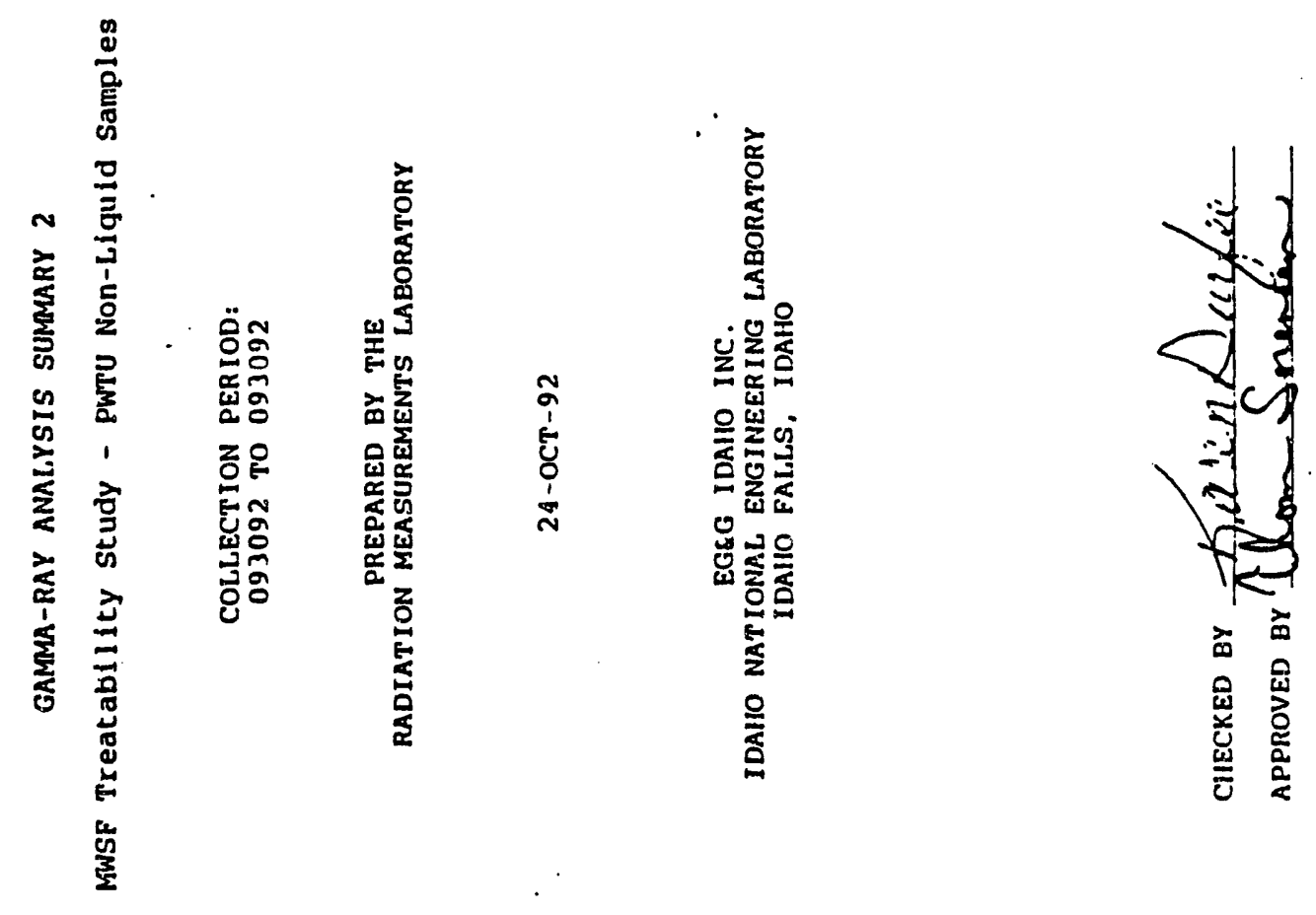

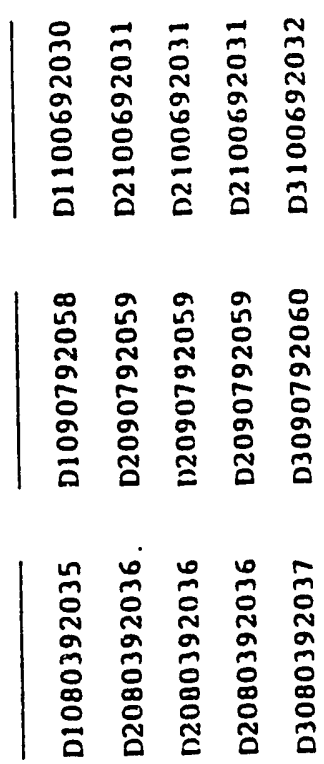

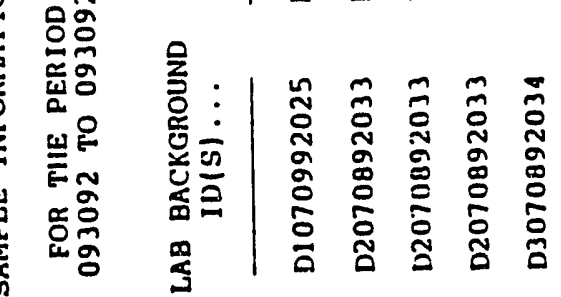

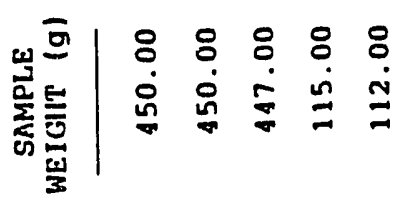

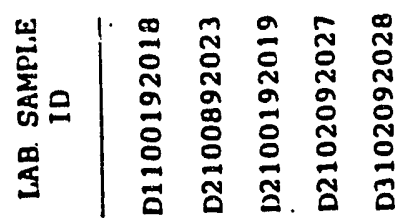

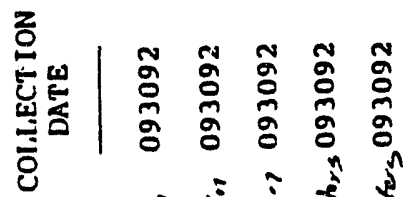

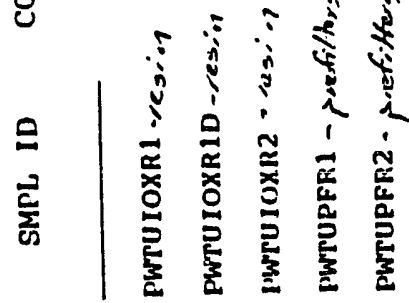




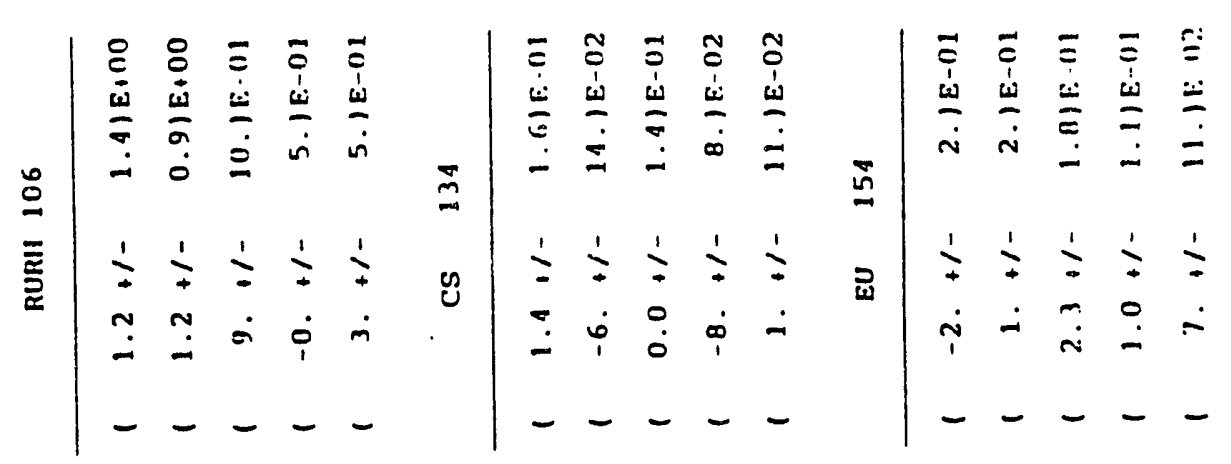

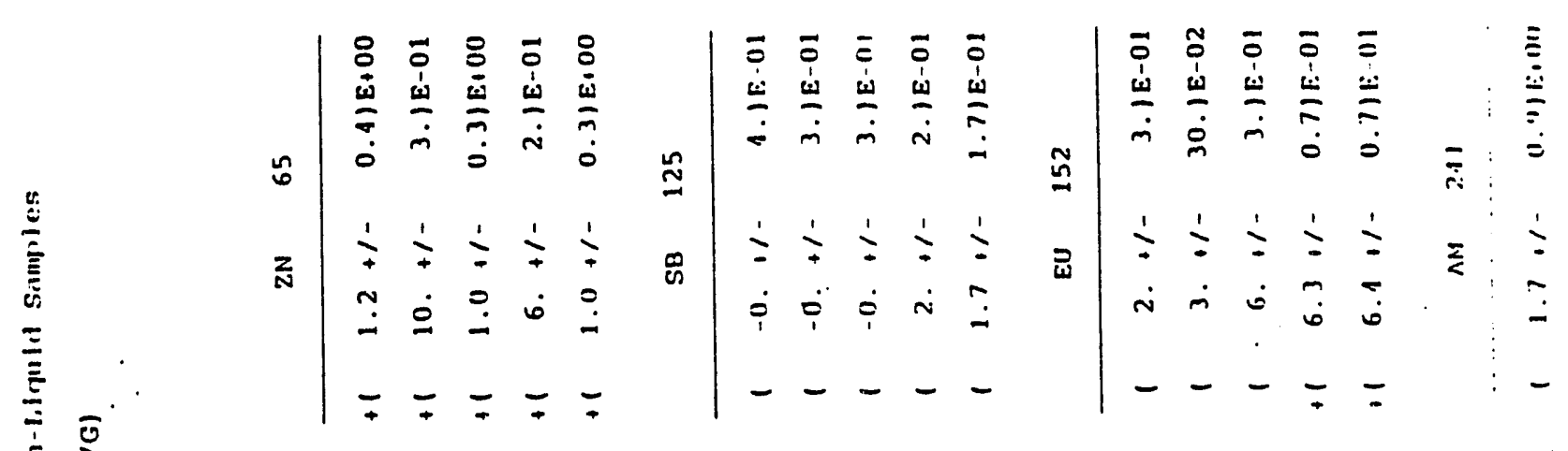

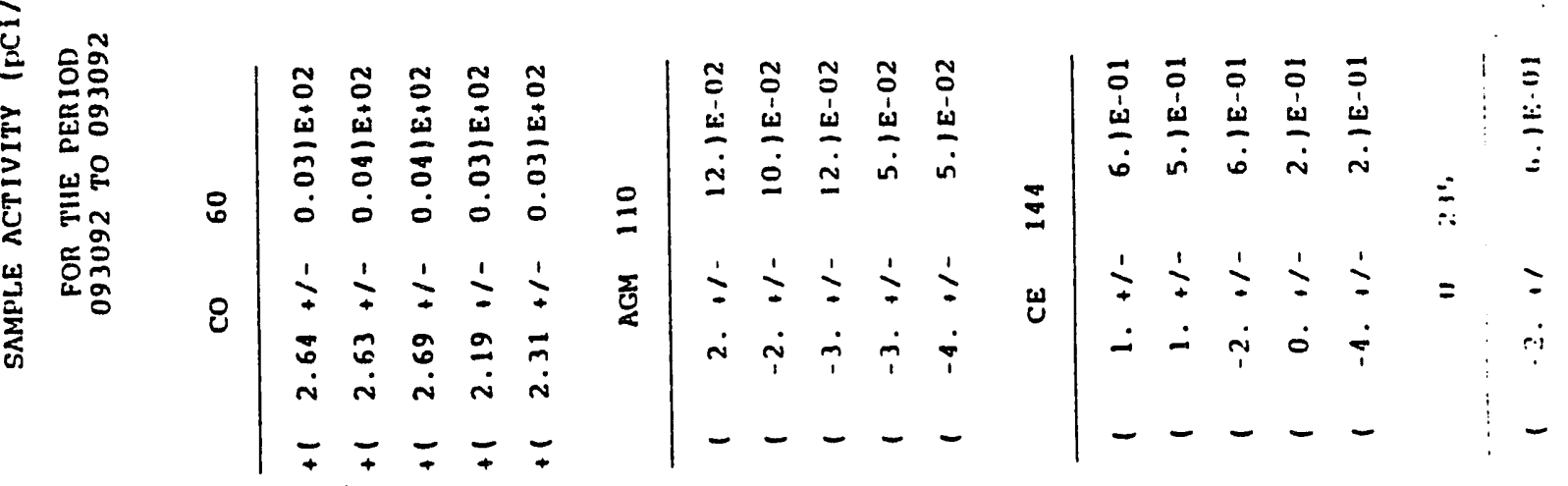

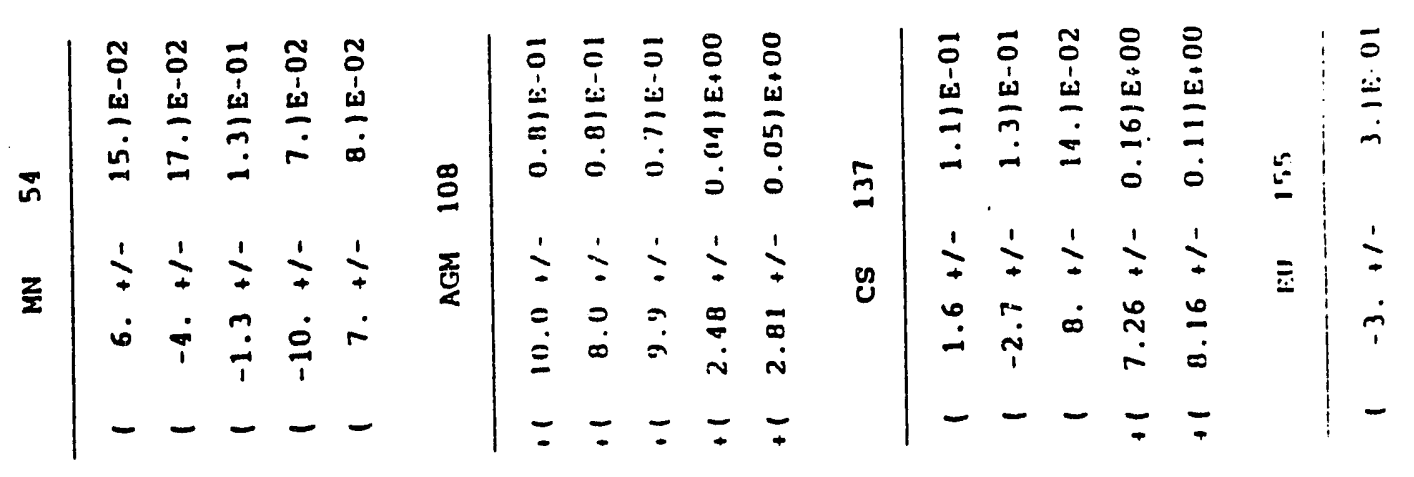

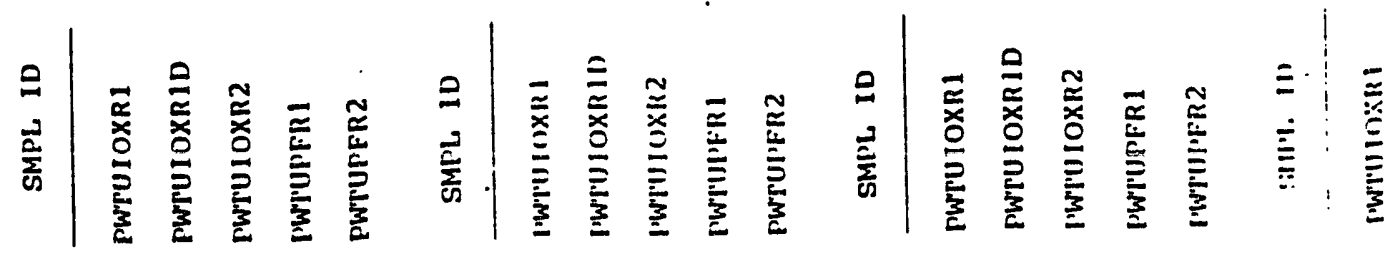




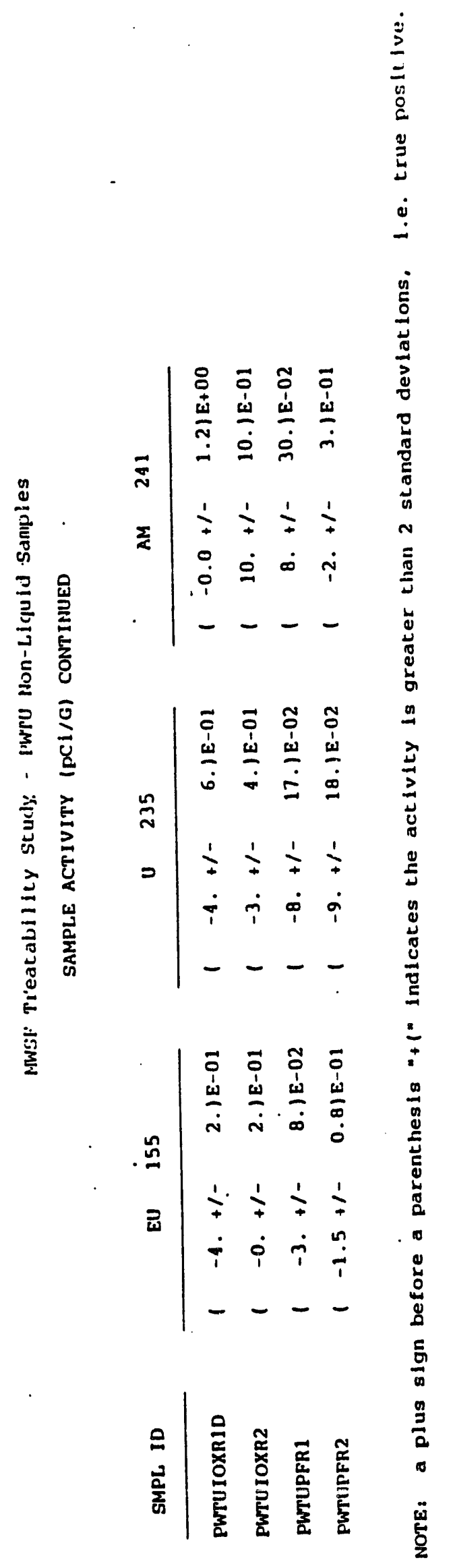

D-14 


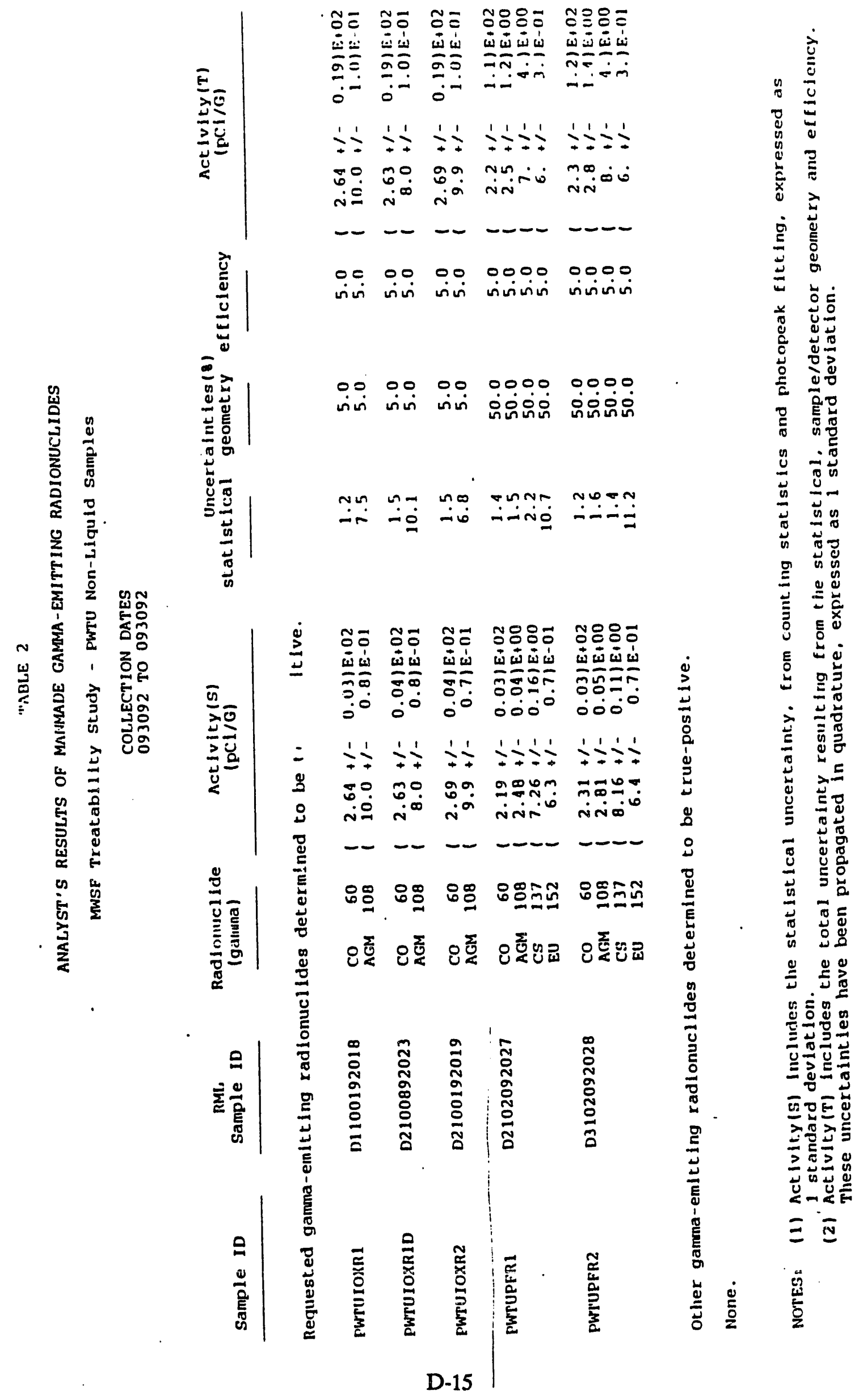




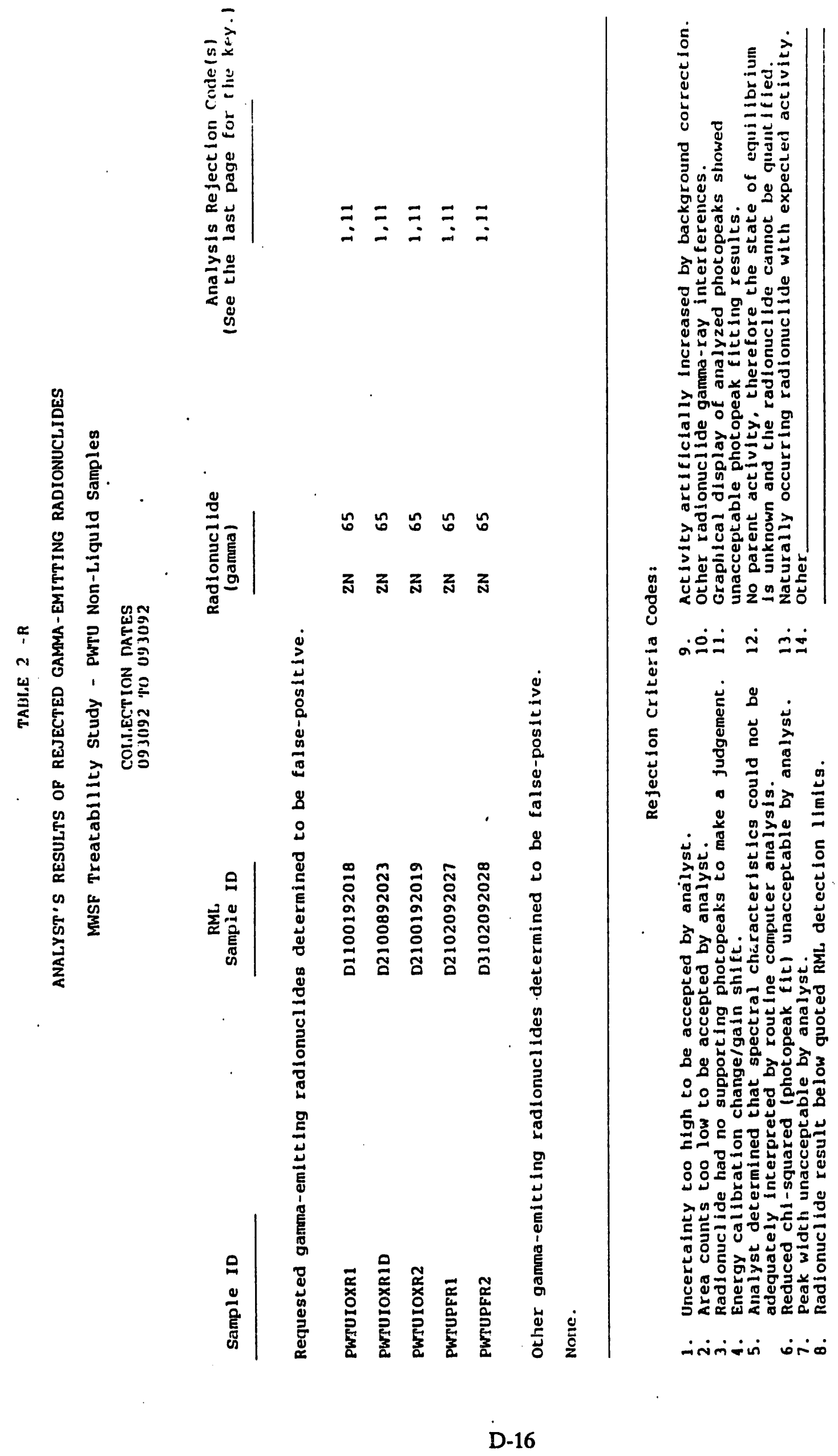


Appendix E

\section{TCT TCLP Test Results}

E-1 
SAMPLE ID KEY

\begin{tabular}{|c|c|c|c|}
\hline EGG SAMPLE NUMBER & SAMPLE SOURCE & $\begin{array}{l}\text { ANALYSIS } \\
\text { PERFORMED } \\
\end{array}$ & DATE \\
\hline PWTUF ILESCLR & CONSOLIDATED LIQUIDS & $\begin{array}{l}\text { (RML) } \\
\text { RADIOCHEMISTRY }\end{array}$ & $9 / 10 / 92$ \\
\hline PWTUFILE8CLT & CONSOLIDATED LIQUIDS & (TCT) FULL TCLP & $9 / 10 / 92$ \\
\hline PWTUFILE8CLTB 1 & TRIP BLANK & (TCT) TCLP VOA & $9 / 10 / 92$ \\
\hline PWTUF ILE8CLTB2 & TRIP BLANK & (TCT) TCLP VOA & $9 / 10 / 92$ \\
\hline PWTUF ILEBTLSI & $\begin{array}{l}\text { TRIAL } 1 \text { TREATED LIQUID } \\
\text { TANK } 1\end{array}$ & $\begin{array}{l}\text { (ECU) FULL METALS } \\
\text { SCREENING } \\
\end{array}$ & $9 / 15 / 92$ \\
\hline PWTUF ILE8TLS2 & $\begin{array}{l}\text { TRIAL } 1 \text { TREATED LIQUID } \\
\text { TANK } 2 \text {. }\end{array}$ & $\begin{array}{l}\text { (ECU) FULL METALS } \\
\text { SCREENING }\end{array}$ & $9 / 15 / 92$ \\
\hline PWTUF ILE8TLTI & $\begin{array}{l}\text { TRIAL } 1 \text { TREATED LIQUID } \\
\text { TANK } 1\end{array}$ & $\begin{array}{l}\text { (TCT) TCLP } \\
\text { METALS, SEMI-VOA, } \\
\text { PESTICIDES, AND } \\
\text { HERBICIDES } \\
\end{array}$ & $9 / 16 / 92$ \\
\hline PWTUF ILE8TLT2 & $\begin{array}{l}\text { TRIAL } 1 \text { TREATED LIQUID } \\
\text { TANK } 2\end{array}$ & $\begin{array}{l}\text { (TCT) TCLP } \\
\text { METALS, SEMI -VOA, } \\
\text { PESTICIDES, AND } \\
\text { HERBICIDES } \\
\end{array}$ & $9 / 16 / 92$ \\
\hline PWTUF ILE8TLVI & $\begin{array}{l}\text { TRIAL } 1 \text { TREATED LIQUID } \\
\text { TANK } 1\end{array}$ & (TCT) TCLP VOA & $9 / 16 / 92$ \\
\hline PWTUF ILE8TLV2 & $\begin{array}{l}\text { TRIAL } 1 \text { TREATED LIQUID } \\
\text { TANK } 2\end{array}$ & (TCT) TCLP VOA & $9 / 16 / 92$ \\
\hline PWTUF ILE8TLTB3 & TRIP BLANK & (TCT) TCLP VOA & $9 / 16 / 92$ \\
\hline PWTUTW1T & $\begin{array}{l}\text { TRIAL } 2 \text { TREATED LIQUID } \\
\text { TANK } 1\end{array}$ & $\begin{array}{l}\text { (TCT) TCLP } \\
\text { METALS, SEMI -VOA, } \\
\text { PESTICIDES, AND } \\
\text { HERBICIDES } \\
\end{array}$ & $9 / 30 / 92$ \\
\hline PWTUTW2T & $\begin{array}{l}\text { TRIAL } 2 \text { TREATED LIQUID } \\
\text { TANK } 2\end{array}$ & $\begin{array}{l}\text { (TCT) TCLP } \\
\text { METALS, SEMI -VOA, } \\
\text { PESTICIDES, AND } \\
\text { HERBICIDES } \\
\end{array}$ & $9 / 30 / 92$ \\
\hline PWTUTWIV & $\begin{array}{l}\text { TRIAL } 2 \text { TREATED LIQUID } \\
\text { TANK } 1\end{array}$ & (TCT) TCLP VOA & $9 / 30 / 92$ \\
\hline PWTUTW2V & $\begin{array}{l}\text { TRIAL } 2 \text { TREATED LIQUID } \\
\text { TANK } 2\end{array}$ & (TCT) TCLP VOA & $9 / 30 / 92$ \\
\hline PWTUTWTB & TRIP BLANK & (TCT) TCLP VOA & $9 / 30 / 92$ \\
\hline
\end{tabular}




\begin{tabular}{|c|c|c|c|}
\hline EGG SAMPLE NUMBER & SAMPLE SOURCE & $\begin{array}{l}\text { ANALYSIS } \\
\text { PERFORMED }\end{array}$ & DATE \\
\hline PWTUTLTW1M & $\begin{array}{l}\text { TRIAL } 2 \text { TREATED LIQUID } \\
\text { REANALYSIS TANK } 1 \\
\end{array}$ & $\begin{array}{l}\text { (TCT) TCLP } \\
\text { MERCURY ONLY } \\
\end{array}$ & $10 / 6 / 92$ \\
\hline PWTUTLTW2M & $\begin{array}{l}\text { TRIAL } 2 \text { TREATED LIQUID } \\
\text { REANALYSIS TANK } 2\end{array}$ & $\begin{array}{l}\text { (TCT) TCLP } \\
\text { MERCURY ONLY }\end{array}$ & $10 / 6 / 92$ \\
\hline PWTUTW12TSM & $\begin{array}{l}\text { TRIAL } 2 \text { TREATED LIQUID } \\
\text { REANALYSIS TANK } 1 \& 2 \text { MIX } \\
\end{array}$ & $\begin{array}{l}\text { (ECU) TCLP } \\
\text { MERCURY ONLY } \\
\end{array}$ & $10 / 6 / 92$ \\
\hline PWTUTWF ITS & $\begin{array}{l}\text { TRIAL } 3 \text { TREATED LIQUID } \\
\text { TANK } 1\end{array}$ & $\begin{array}{l}\text { (ECU) TCLP } \\
\text { MERCURY ONLY }\end{array}$ & $10 / 22 / 92$ \\
\hline PWTUTWF2TS & $\begin{array}{l}\text { TRIAL } 3 \text { TREATED LIQUID } \\
\text { TANK } 2\end{array}$ & $\begin{array}{l}\text { (ECU) TCLP } \\
\text { MERCURY ONLY } \\
\end{array}$ & $10 / 22 / 92$ \\
\hline PWTUTWF 1M & $\begin{array}{l}\text { TRIAL } 3 \text { TREATED LIQUID } \\
\text { TANK } 1\end{array}$ & $\begin{array}{l}\text { (TCT) TCLP } \\
\text { MERCURY ONLY }\end{array}$ & $10 / 22 / 92$ \\
\hline PWTUTWF2M & $\begin{array}{l}\text { TRIAL } 3 \text { TREATED LIQUID } \\
\text { TANK } 2\end{array}$ & $\begin{array}{l}\text { (TCT) TCLP } \\
\text { MERCURY ONLYY }\end{array}$ & $10 / 22 / 92$ \\
\hline PWTUTW1R & $\begin{array}{l}\text { TRIAL } 1 \text { TREATED LIQUID } \\
\text { TANK } 1\end{array}$ & $\begin{array}{l}\text { (RML) } \\
\text { RADIOCHEMISTRY }\end{array}$ & $9 / 30 / 92$ \\
\hline PWTUTW2R1 & $\begin{array}{l}\text { TRIAL } 1 \text { TREATED LIQUID } \\
\text { TANK } 2\end{array}$ & $\begin{array}{l}\text { (RML) } \\
\text { RADIOCHEMISTRY }\end{array}$ & $9 / 30 / 92$ \\
\hline PWTUTW2R2 & $\begin{array}{l}\text { TRIAL } 1 \text { TREATED LIQUID } \\
\text { TANK } 2\end{array}$ & $\begin{array}{l}\text { (RML) DUPLICATE } \\
\text { RADIOCHEMISTRY } \\
\end{array}$ & $9 / 30 / 92$ \\
\hline PWTUIOXR1 & $\begin{array}{l}\text { ION EXCHANGE RESIN } \\
\text { CONSOLIDATED SAMPLE } 1 \\
\end{array}$ & $\begin{array}{l}\text { (RML) } \\
\text { RADIOCHEMISTRY } \\
\end{array}$ & $9 / 30 / 92$ \\
\hline PWTUIOXR2 & $\begin{array}{l}\text { ION EXCHANGE RESIN } \\
\text { CONSOLIDATED SAMPLE } 2 \\
\end{array}$ & $\begin{array}{l}\text { (RML) } \\
\text { RADIOCHEMISTRY }\end{array}$ & $9 / 30 / 92$ \\
\hline PWTUPFRI & $\begin{array}{l}\text { FILTERS CONSOLIDATED } \\
\text { SAMPLE } 1 \\
\end{array}$ & $\begin{array}{l}\text { (RML) } \\
\text { RADIOCHEMISTRY } \\
\end{array}$ & 9/30/92 \\
\hline PWTUPFR2 & $\begin{array}{l}\text { FILTERS CONSOLIDATED } \\
\text { SAMPLE } 2\end{array}$ & $\begin{array}{l}\text { (RML) } \\
\text { RADIOCHEMISTRY }\end{array}$ & 9/30/92 \\
\hline PWTUIOXTI & $\begin{array}{l}\text { ION EXCHANGE RESIN } \\
\text { CONSOLIDATED SAMPLE } 1 \\
\end{array}$ & (TCT) FULL. TCLP & $9 / 30 / 92$ \\
\hline PWTUIOXT2 & $\begin{array}{l}\text { ION EXCHANGE RESIN } \\
\text { CONSOLIDATED SAMPLE } 2 \\
\end{array}$ & (TCT) FULL TCLP & $9 / 30 / 92$ \\
\hline PWTUIOXC1 & $\begin{array}{l}\text { ION EXCHANGE RESIN } \\
\text { CONSOLIDATED SAMPLE I }\end{array}$ & (TCT) CORROSIVITY & $9 / 30 / 92$ \\
\hline
\end{tabular}




\begin{tabular}{||l|l|l|l||}
\hline EGG SAMPLE NUMBER & SAMPLE SOURCE & $\begin{array}{l}\text { ANALYSIS } \\
\text { PERFORMED }\end{array}$ & DATE \\
\hline \hline PWTUIOXC2 & $\begin{array}{l}\text { ION EXCHANGE RESIN } \\
\text { CONSOLIDATED SAMPLE 2 }\end{array}$ & (TCT) CORROSIVITY & $9 / 30 / 92$ \\
\hline PWTUPFT1 & $\begin{array}{l}\text { FILTERS CONSOLIDATED } \\
\text { SAMPLE 1 }\end{array}$ & (TCT) FULL TCLP & $9 / 30 / 92$ \\
\hline PWTUPFT2 & $\begin{array}{l}\text { FILTERS CONSOLIDATED } \\
\text { SAMPLE 2 }\end{array}$ & (TCT) FULL TCLP & $9 / 30 / 92$ \\
\hline PWTUPFC1 & $\begin{array}{l}\text { FILTERS CONSOLIDATED } \\
\text { SAMPLE 1 }\end{array}$ & (TCT) CORROSIVITY & $9 / 30 / 92$ \\
\hline PWTUPFC2 & $\begin{array}{l}\text { FILTERS CONSOLIDATED } \\
\text { SAMPLE 2 }\end{array}$ & (TCT) CORROSIVITY & $9 / 30 / 92$ \\
\hline
\end{tabular}


October 22, 1992

9259-00002,7
St. Louis, Missouri 63114-5700

Phone (314) 426-0350

Fax (314) 426-4212

Ms. Donna Kirchner

Field Data Coordinator

ERP Administrative Record

and Document Control

EG\&G Idaho, Inc.

P.O. Box 1625

Idaho Falls, ID 83415-3904

Re: Data Package for Task Order 15 Under Subcontract C92-170021

Dear Ms. Kirchner:

Enclosed is a data report for the analysis of samples received by TCT-St. Louis under subcontract No. C92-170021/Task Order 15, (TOS No. ERD-TOS-02, MOD 1). This report contains analytical sample data for samples collected from treatability studies being conducted at the Test Reactor Area (TRA).. The samples were analyzed specifically for TCLP metals, TCLP pesticides, and TCLP herbicides.

The samples were received by TCT-St. Louis on September 16 and 18, 1992 with a stated turn-around time of 35 days from receipt of the last sample in the SDG. The due date for the final report is October 23,1992 . The preliminary report of the quick turn around water samples was delivered on October 2 and 5, 1992 to Isabel Anderson.

The EG\&G site codes, corresponding File I.D.'s, TCT-St. Louis laboratory sample numbers for each sample delivery group are shown in the following tables.

SDG SDG PWTBT1 - VOA

EG\&G SITE ID $\quad$ FILE ID TCT LAB NO.

"PWTUTBT1 AND 2

PWTUFLE8TLV1

PWTUFILE8TLV2

PWTUFILE8TB3

\begin{tabular}{|c|c|}
\hline \multicolumn{2}{|c|}{ PWTBT1 } \\
\hline FILLV1 & 92006146 \\
\hline FILLV2 & 92006147 \\
\hline FILTB3 & 92006148 \\
\hline
\end{tabular}

\section{DATE COLLECTED}

9/10/92

$9 / 16 / 92$

$9 / 17 / 92$

9/17/92

-

SDG PWTCLT - TCLP METALS, PESTICIDES, HERBICIDES, SEMTVOLATILES EG\&G SITE ID FILE ID TCT LAB NO. DATE COLLECTED

PWTUFILE8CLT
PWTUFILETLT1
PWTUFILETLT2

$\begin{array}{lll}\text { PWTCLT } & 92006115 & 9 / 10 / 92 \\ \text { FILLT1 } & 92006144 & 9 / 16 / 92 \\ \text { FILIT2 } & 92006145 & 9 / 17 / 92\end{array}$


TCT-St. Louis

9259-0002,7

page 2

For reporting purposes, the contract number is ERDTOSO2 and case number TOS02. All samples were analyzed and reported per the requirements of C92-170021 TASK ORDER NO. 15, ERD-TOS-02 MOD 2.

The yellow original chain-of-custodies were mailed to Donna Kirchner on September 16 and 18, 1992.

\section{TCLP VOLATILES - SDG PWTBT1}

The samples were analyzed within the required holding times. A CLP equivalent data package has been prepared. A matrix spike and a matrix spike duplicate were performed on sample FIILT2. The surrogate recoveries for sample FIILT2 were out of range in both the sample analysis and the matrix spike sample analysis. A sample matrix effect is indicated since the surrogates were out of range in three analyses of this sample. The trip blank was analyzed for total volatiles and is included in the same SDG with the TCLP samples.

\section{TCLP PESTICIDES - SDG PWTCLT}

The samples were analyzed within the required holding times. A CLP equivalent data package has been prepared. A matrix spike and a matrix spike duplicate were performed on sample FILLT2.

\section{TCLP HERBICDES - SDG PWTCLT}

The samples were analyzed within the required holding times. A CLP equivalent data package has been prepared. A matrix spike and a matrix spike duplicate were performed on sample FILIT2.

\section{TCLP SEMIVOLATILES - SDG PWTCLT}

The samples were analyzed within the required holding times. A CLP data package has been prepared. A matrix spike and matrix spike duplicate were performed on sample FILLT2.

\section{TCLP METALS - SDG PWTCLT}

The samples were analyzed within the required holding times. A CLP equivalent data package has been prepared. A matrix spike and duplicate analysis were performed on sample FILLT2. The Selenium matrix spike was not recovered. This is due in part to the 20 fold dilution required by the TCLP sample matrix. The bench spike recoveries were acceptable for TCLP analysis of Selenium. 
TCT-St. Louis

9259-00002,7

page 3

This work will be invoiced under purchase order number C92-170021 and TCT-St. Louis project number - 9259-00002,7.

If you have any questions concerning this data report, please call me at (314) 426-0880.

Sincerely,

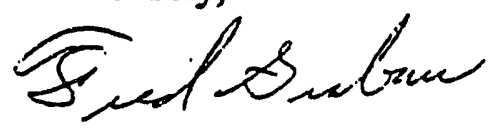

Fred Grabau

Project Manager 
Lab Name: TCT-ST. LOUIS

Lab Code: TCT

Ćáse No.: TOSO2 SAS No.:

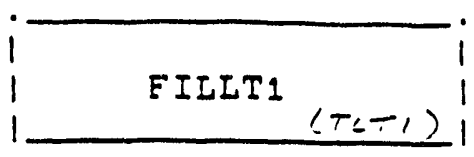

Sample Matrix: (soil/water/other) WATER

Lab Sample ID: 92006144

Extract Matrix: (water) WATER

Lab File ID:

>D8533

Extract vol: 500 (ml) ML

Date Received: 09/18/92

Level: (low/med) LOW

Date of TCLP Ext. 09/21/92

* Moisture: dec. not dec.

Date Extracted: $09 / 22 / 92$

Extraction: (Sepf/Cont/Sonc) SEPF

Date Analyzed: $09 / 24 / 92$

GPC Cleanup: $(Y / N) N \quad$ pH: 8

Dilution Factor: 1

CAS NO.

COMPOUND

$\begin{gathered}\text { CONCENTRATION } \\ \text { UNITS } \\ (U g / L)\end{gathered}$ Q
CONCENTRATION
$(U g / L)$

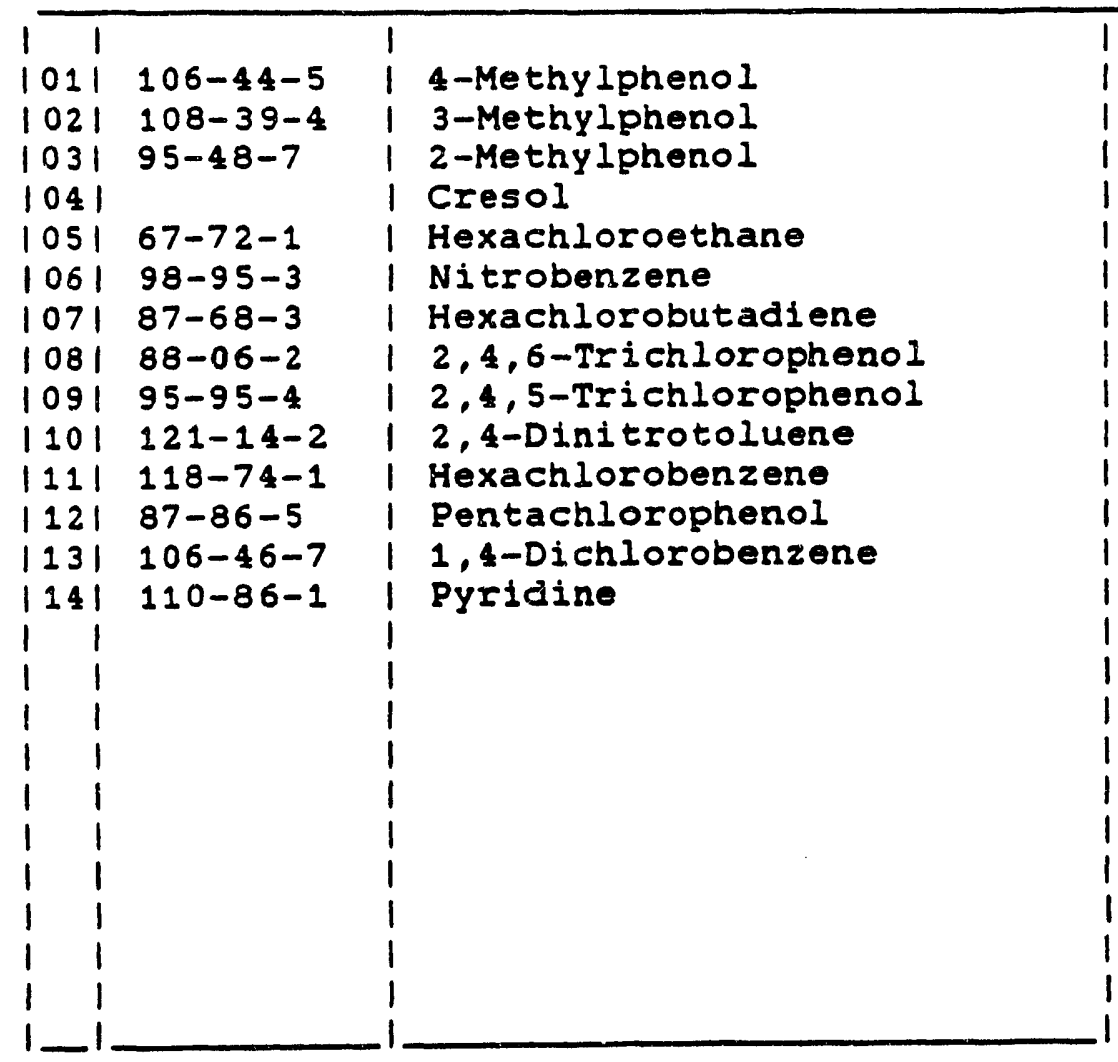

FORM I SV-TCLP

(1) Treated Liguri Tark! - Sermi-veA 


\section{ORGANOCHLORINE PESTICIDE ANALYSIS DATA SHEET

EGaG Samole No.

Lab Mame: ICT ST Louls Contract: ERDTOSOL FILLTI

Lab Code: INT Case No.: TOS.Oz SAS No.: SDG No.: PWTCLT

Sample Matrix: (soil/water/other) WeTES Lab Sample ID: $93006 / 44$

Extract Matrix: (water) WUETER

Lab File 10:

Extract vol: $500(\mathrm{~mL}) \mathrm{mL}$

Date Recatved: $9-18-92$

Level: (low) Low

Oate of TCLP Extraction: $9.21-92$

* Moisture: not dec. NA dec. NA

Date Extracted: 9-32-92

Preparatory Extraction: (SepF/Cont) SEPE

GPC Cleanup: (Y/M) N PH: 8.0

Date Analyzed: $9.24-92$

Dilution Factor: 1

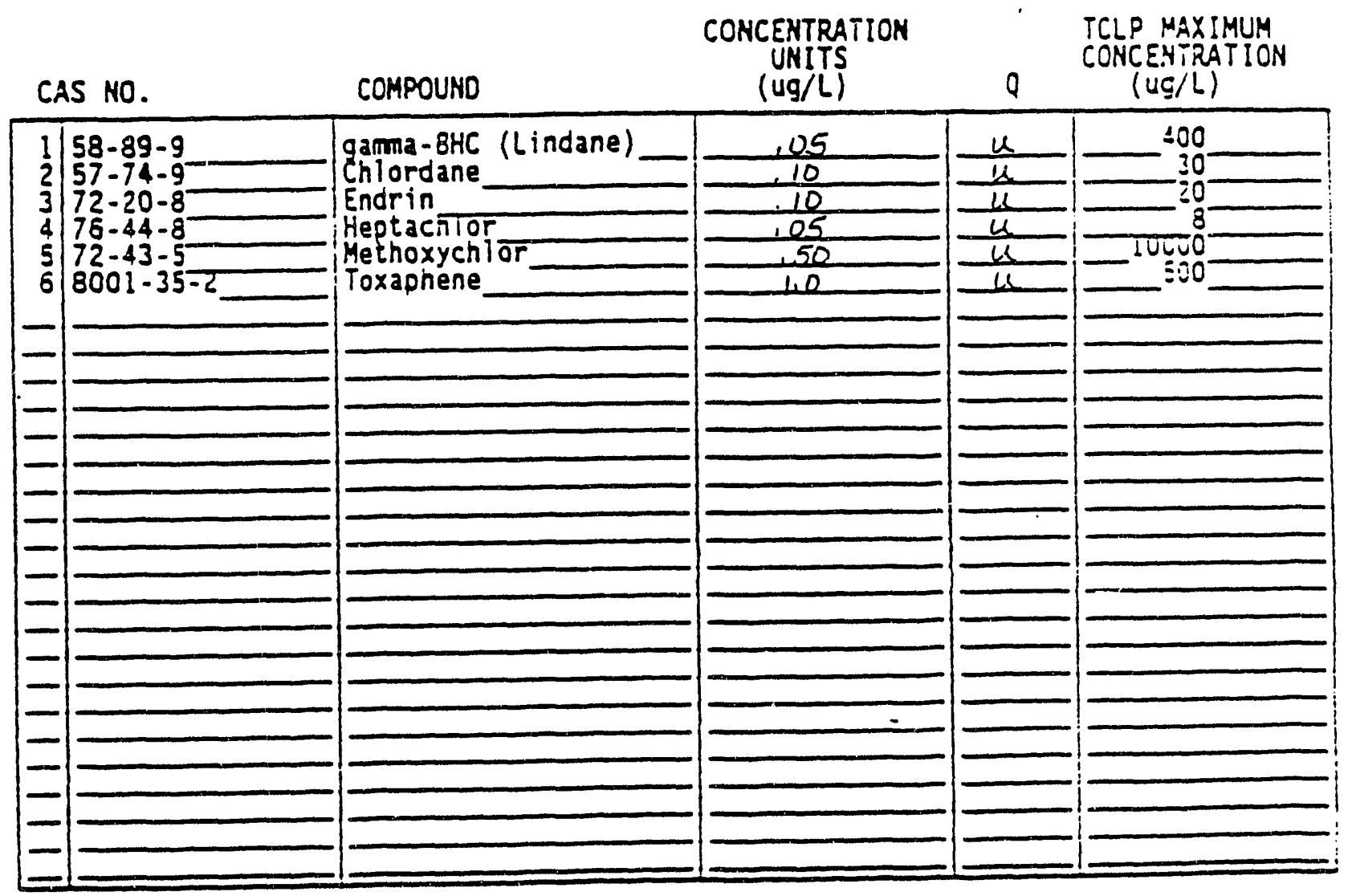

FORM 1 OCPEST-TCLP

7/91 Rey. 


\section{ORENDCHLORINE HERBICIDE MULYSIS CATA SRET \\ YELP}

Esos storle No.

La Nane: $T<T$ T. Lavis

Contract: ERTTOSO2

Fi- T :

LaE Cooe: TET Case Hc.: TSSCZ SAS Ho.: NA SOG Ho.: PWTCLT

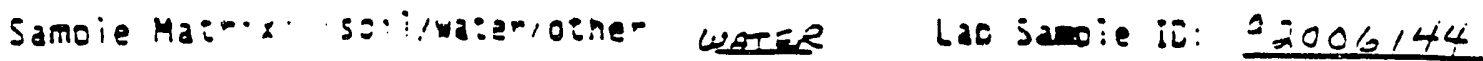

¿x:-ac: Ma:-ls, iwa:er: WATER

Las : : ie I: NA NA

Exi-as: vo $5001 \mathrm{mo} M L$

Cate-Resz-ves: $\quad \underline{9-13.42}$

seve': fiow. Low

* Morsture: no: des. NA des. $N A$

Dase of TCL: Ex:-ac:ion: $9-21-92$

Extrac:ion: (hert) Hers

Daie Extracted: $\underline{0-2 z-92}$

GPe Cleanud: $(Y / N) \Delta$ pri: 7

Date Analyzed: $\quad 9-24-9=$

Dilution Factor: 1.0

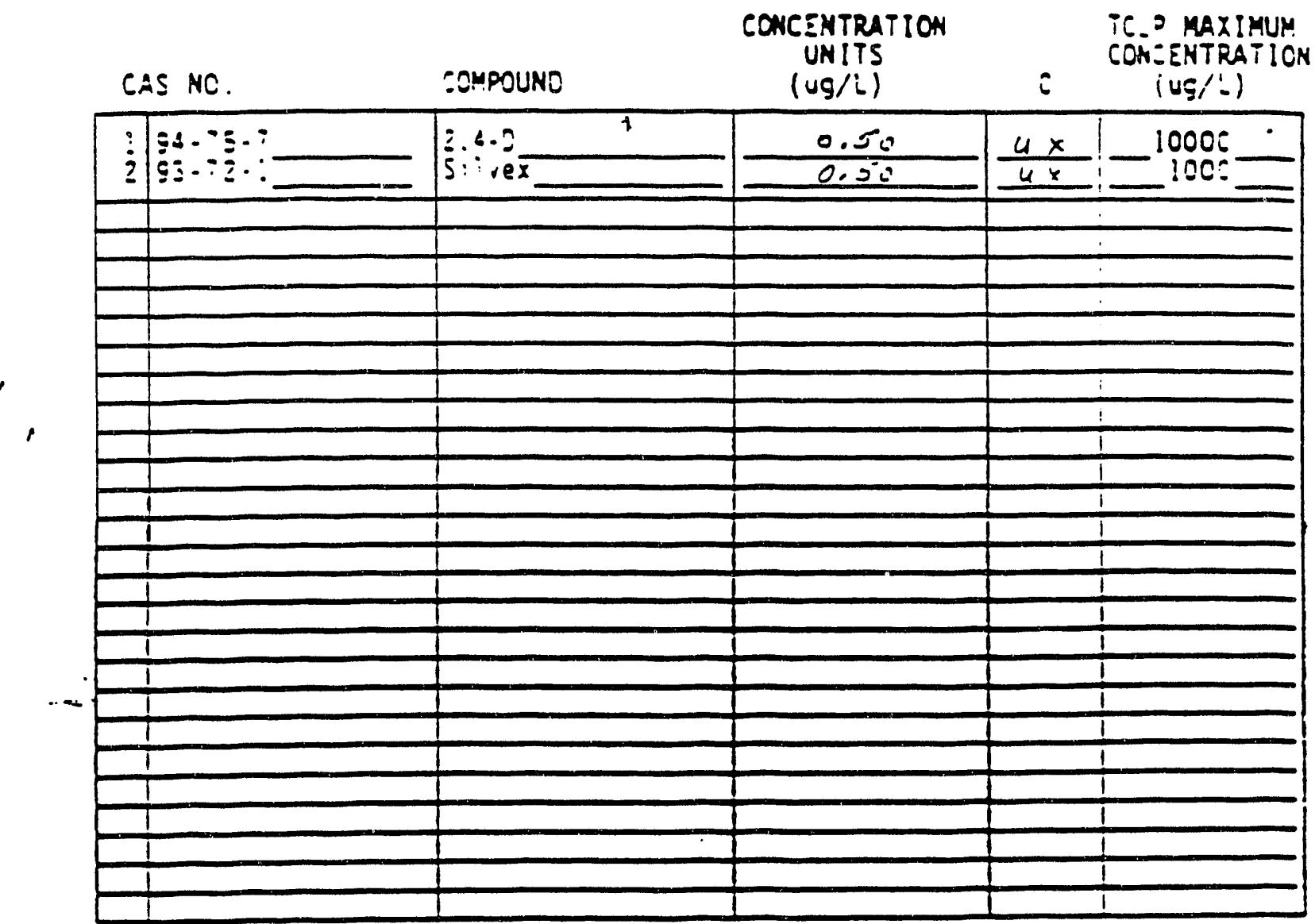

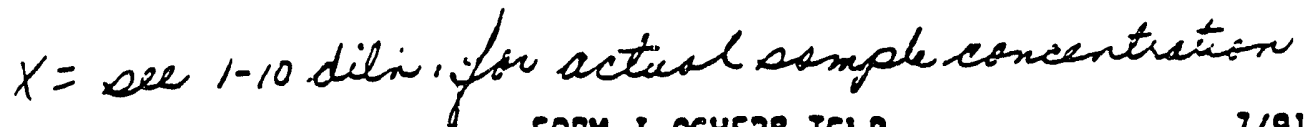
FORH I OCHERB-TCL?

T/91 Rer. 


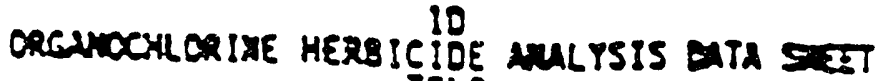 TCLP}

Esse s200le No.

bao Hame: $T=T . \quad T$ Louis

Las Cooe: TE- Case No.: TCSCa SAS Mo.

Samoie Ma:-': sali/waterioiner weter

Ex:-ac: Ma:-l: wd:er. WATER

Exi:a:: $v:^{\circ}$ SOC $(m, M L$

-eve': liow Low

: Mo'stu-e: ne: des. NA der. NA

Exirac:ior: (here) Herb

GPC Cieanud: (T/N) $\perp$ PH: 7

Concrac: ERTTCSO2 flLL TI DL

506 No.: PNT TLLT

Lac janie if: $\$ 2006 / 44$

Las : : :a : : N NA

Oa:e-ñeza-ves: $\quad q-18-q 2$

Dase o: TL: Extrac:ion: $9-21-92$

Date Estracted: $9.22-92$

Date Analyes: $\quad 9-24-92$

Dilution Factor: 10.0

COACENTRATION

UNITS

\begin{tabular}{|c|c|}
\hline CAS NC. & :OMPOUNO \\
\hline 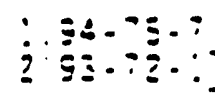 & 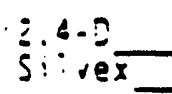 \\
\hline
\end{tabular}

$(4 g / L)$

TC. 2 MAXIMUM

COHEENTRATION (Ug/:-)

$\frac{2.15 .0}{5.0}-\frac{40}{40}=10000$ 
Lab Name: TCT St. Louis

Lab Code: TCT

Case No.: TOSO2
COntract: ERDTOSO2

SAS NO.:
FIニ二TI

PWTCLI
Matrix (soil/water): WATER

Level (low/med): LOW

\& Solids :

0.0

Concentration Units (ug/L or mg/kg dry weight): UG/L

\begin{tabular}{|c|}
\hline CAS NO. \\
\hline$\frac{7440-38-2}{\frac{7440-39-3}{7440-43-5}} \frac{7440-47-}{\frac{7439-92-1}{7439-97-6}} \frac{782-49-2}{7440-22-}$ \\
\hline
\end{tabular}

$\mid$\begin{tabular}{|l|}
$\frac{\text { Analyte }}{\text { Arsenic }}$ \\
\hline$\frac{\text { Barium }}{\text { Cadmium }}$ \\
$\frac{\text { Chromium }}{\text { Lead }}$ \\
$\frac{\text { Mercury }}{\text { Selenium }}$ \\
\hline Silver
\end{tabular}

\begin{tabular}{|}
$\frac{\text { Concentration }}{\frac{71.0}{271}}$ \\
\hline$\frac{9.0}{6.0}$ \\
\hline$\frac{22.0}{264}$ \\
\hline 40.0 \\
\hline 5.0
\end{tabular}

Lab Sample

SDG NO.: : $=\frac{1}{2}$ $20 \times 4$

Date Received: $09 / 18 / 92$

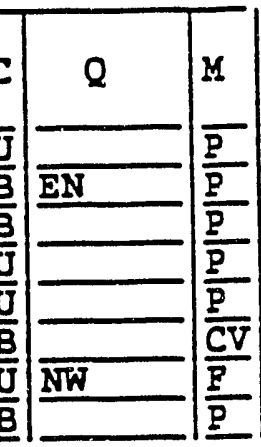

Color Before:

Clarity Before:

Texture:

Color After:

clarity After:

Artifacts :

Comments :

FORM I - IN

E-12 
le: TCT-ST. LOUIS

Contract: ERDTOSO2

le: TCT

Case No.: TOSO2

SAS

Matrix: (soil/water/other) WATER

: Matrix: (water) MATER

: vol: 500 (ml) ML

( Low/med) LOW

:ure: dec. not dec.

:ion: (Sepf/Cont/Sonc) SEPE

sanup: $(Y / N) N \quad \mathrm{pH}: 8$

CAS No.
EGä́ Sample No.

EILII2

SDG NO.: PWTCIT

Lab Sample ID: 92006145

Lab File ID: गD8534

Date Received: $09 / 18 / 92$

Date of TCIP EXE. $09 / 21 / 92$

Date Extracted: $09 / 22 / 92$

Date Analyzed: $09 / 24 / 92$

Dilution Factor: 1

CONCENTRATION UNITS

(ug/L)
TCLP MAXIMUM CONCENTRATION

$(u g / L)$

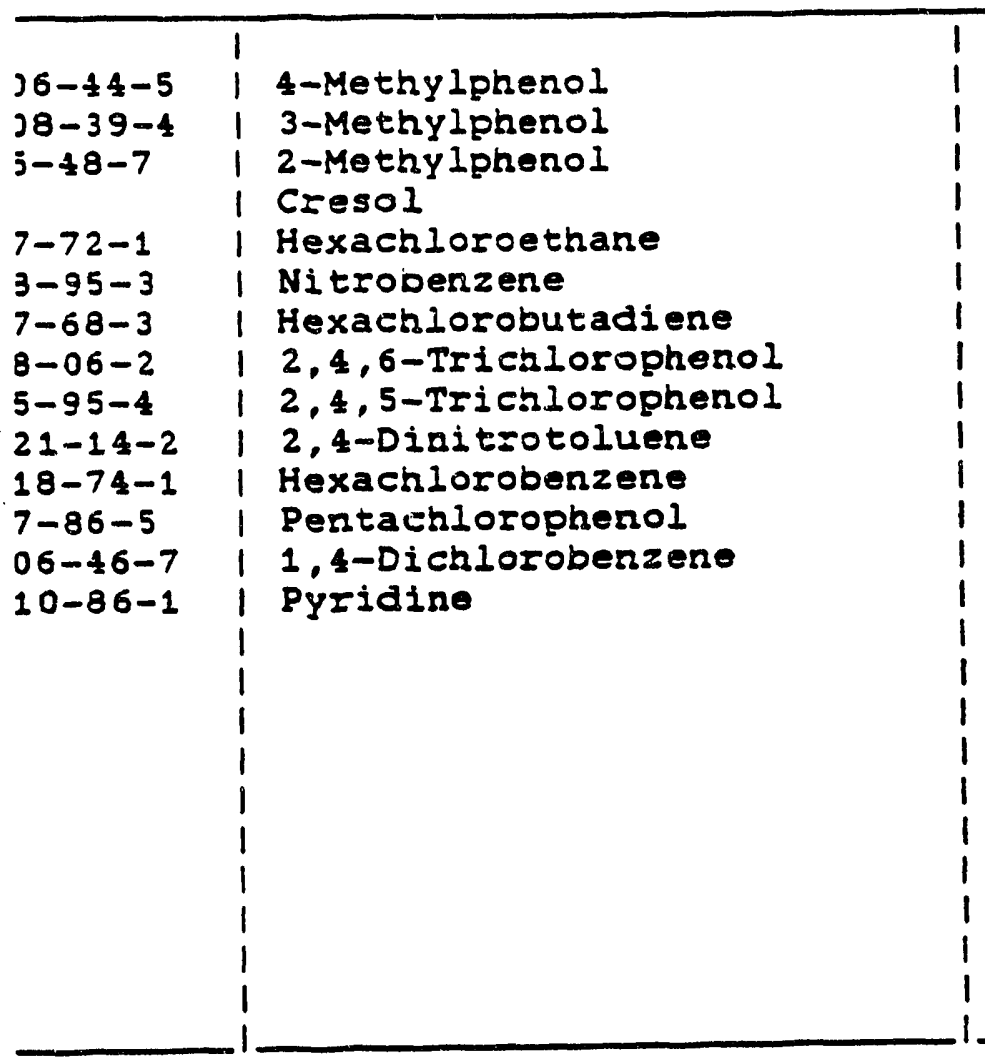

FORM I SV-TCLP
200000

200000

200000

200000

3000

2000

500

2000

400000

130

130

100000

7500

5000 
1

INORGANIC ANALYSIS DATA SHEET

Lab Name: TCT St. Louis

Lab Code: TCT

Case No.: TOSO2
Contract: ERDTOSO2

SAS NO.:

\section{FIIIT2}

SDG NO PUTCLT

Iab Sample ID: $92006145^{10.414}$.

Matrix (soil/water): WATER

Date Received: 09/18/92

Level (low/med): IOW

0.0

\& Solids :

Concentration Units (ug/L or mg/kg dry weight): UG/J

\begin{tabular}{|c|}
\hline CAS No. \\
\hline$\frac{7440-38-2}{\frac{7440-39-3}{7440-43-9}} \frac{7440-47-3}{\frac{7439-92-1}{7439-97-6}} \frac{782-49-2}{7440-22-4}$ \\
\hline
\end{tabular}

\begin{tabular}{|l|}
\hline Analyte \\
\hline$\frac{\text { Arsenic }}{\text { Barium }}$ \\
$\frac{\text { Cadmium }}{\text { Chromium }}$ \\
$\frac{\text { Lead }}{\text { Mercury }}$ \\
$\frac{\text { Selenium }}{\text { Silver }}$
\end{tabular}

$\begin{array}{r}\text { Concentration } \\ \hline \frac{71.0}{321} \\ \hline \frac{20.0}{11.0} \\ \hline 104 \\ \hline \frac{8.7}{46.0} \\ \hline 10.0\end{array}$

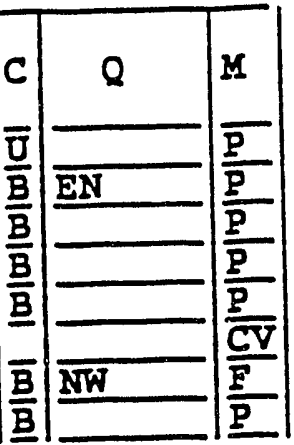

Color Before:

Clarity Before:

Texture:

Color After:

Clarity After:

Artifacts :

\section{Comments :}

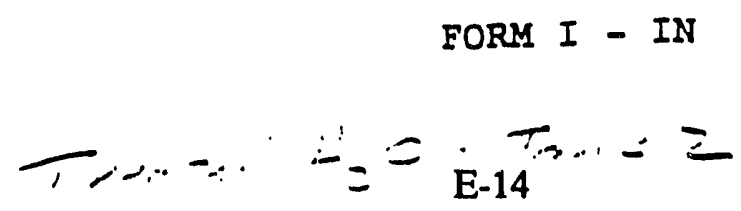


Lan Nari: : TCT-ST. LOUIS

Contrac: : ERDTOSO2

Lab loce: TCI Case No.: TOSO2 SAS No.:

EGaG Samọle No.

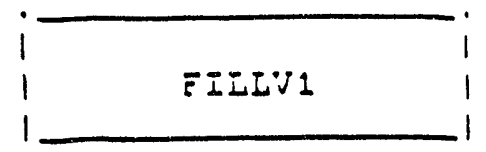

SDG NO.: PWTST:-

Sample Matrix: (s011/water/Other) WATEK

Extrac: Matrıx: (water) WATER

Lab Sample ID: 92006146

Extract vol: 5

(mi) $M E$

Iab File ID:

$>E 2132$

Level: (Low/med) LOW

Date Received: $09 / 18 / 92$

* Morsture: not dec. dec.

Date of ZHE: $09 / 22 / 92$

Column: (nar/wide/pack) WIDE

Date Analyzed: $09 / 25 / 92$

Dilution factor: 5

$\begin{array}{ccc}\text { CONCENTRATION } & \text { TCLP MAXEMUM } \\ \text { UNITS } & \text { CONCENTRATION } \\ (u g / L) & Q & (u g / I)\end{array}$

CAS NO.

COMPOUND

Vinyl chloride

$101175-01-4$

$102175-35-4$

$103167-66-3$

1041 107-00-2

$105178-93-3$

$100150-23-5$

$107179-01-6$

$108171-43-2$

$1091127-18-4$

$110 \mid 108-90-7$

$\begin{array}{ll}1 & 1 \\ 1 & 1 \\ 1 & 1 \\ 1 & 1 \\ 1 & 1 \\ 1 \\ 1 \\ 1 \\ 1 \\ 1 \\ 1 \\ 1 \\ 1\end{array}$
1.1-Dichloroethene

Chloroform

1,2-Dich loroethane

1 2-Butanone

1 Carbon Tetrachloride

1 Trichloroethene

Benzene

Tetrachloroethene

Chlorobenzene

FORM I VOA-TCLP 


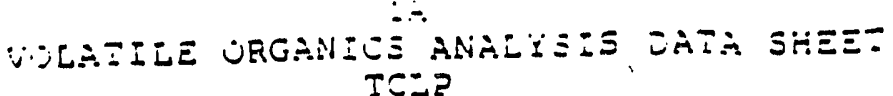

iat Name: TET-ST. LUUIS

Contzact: ERDTOSO2

Lav Code: TCT

Case No.: :OSO2

SAS NO.:

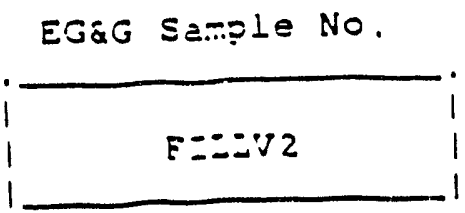

SDG NO.: PWTST1

Sample Matrix: (so11/water/other) WATER

Exeract Matrix: (water) WATER

Extract vol: 5 (ml) $M L$

Level: (Low/med) LOW

Lab Sample ID: $\$ 2006147$

- Moisture: not dec. dec.

Column: (nar/wide/pack) WIDE

Lab File ID: >E2133

Date Received. $09 / 18 / 92$

Date of ZHE: $09 / 22 / 92$

Date Analyzed: 09/25/92

Dilution factor: 5

CONCENTRATION TCLP MAXIMUM

UNITS

$(u g / L)$ CONCENTRATION

$(u g / L)$

CAS NO.

COMPOUND

\begin{tabular}{|c|c|c|}
\hline \multicolumn{3}{|c|}{$1775-01-4$} \\
\hline \multicolumn{3}{|c|}{$\begin{array}{ll}011 & 75-01-4 \\
021 & 75-35-4\end{array}$} \\
\hline \multicolumn{2}{|c|}{$\begin{array}{l}1021 \\
1031\end{array}$} & $\begin{array}{l}75-35-4 \\
67-66-3\end{array}$ \\
\hline \multirow{2}{*}{\multicolumn{2}{|c|}{$\begin{array}{l}1041 \\
1051\end{array}$}} & $107-06-2$ \\
\hline \multirow{2}{*}{\multicolumn{2}{|c|}{$\begin{array}{l}1051 \\
1061\end{array}$}} & $78-93-3$ \\
\hline & & $50-23-5$ \\
\hline \multirow{2}{*}{\multicolumn{2}{|c|}{$\begin{array}{l}1071 \\
1081\end{array}$}} & $79-01-6$ \\
\hline \multirow{2}{*}{\multicolumn{2}{|c|}{1091}} & $71-43-2$ \\
\hline & & $127-18-4$ \\
\hline \multicolumn{2}{|c|}{1101} & $108-90-7$ \\
\hline \multicolumn{2}{|c|}{11} & \\
\hline \multicolumn{2}{|c|}{11} & \\
\hline \multicolumn{2}{|c|}{11} & \\
\hline \multicolumn{2}{|c|}{11} & \\
\hline \multicolumn{2}{|c|}{11} & \\
\hline \multicolumn{2}{|c|}{11} & \\
\hline \multicolumn{2}{|c|}{$\begin{array}{ll}1 & 1 \\
1 & 1\end{array}$} & \\
\hline \multirow{2}{*}{\multicolumn{2}{|c|}{$i \quad i$}} & \\
\hline & 11 & \\
\hline \multicolumn{2}{|c|}{11} & \\
\hline \multirow{2}{*}{\multicolumn{2}{|c|}{$\begin{array}{ll}1 & 1 \\
1 & 1\end{array}$}} & \\
\hline & & \\
\hline \multicolumn{3}{|c|}{$1-1$} \\
\hline
\end{tabular}

Vinyl chloride

1,1-Dichloroethene Chloroform

1,2-Dichloroethane

2-Butanone

Carbon Tetrackloride

Trichloroethene

Benzene

Tetrachloroethene

chlorobenzene 
IA

UOLATILE gRGANILS ANALYSIS DATA SHEET
Lab Name: TCT-ST.LOUIS

Lab Code: TCT Ćase No.: TOSO2

Matrix: (soil/water) WhiER

Sample wt/vol: $5(g / m l) M L$

Leve 1: (low/med) Low

* Mo isture: not dec.

Column: (pack/cap) CAF
E:GG SAMPLE NI.

PITETL

Contract: EROTOSO2

SOE NO.: PWTETI

Lab Samp !e 10: 92006116

Lab File:D: >E2113

Date Received: $09 / 16 / 92$

Date Analyzed: 09/23/92

Dilution Factor: 1

CONCENTRATION UNITS:

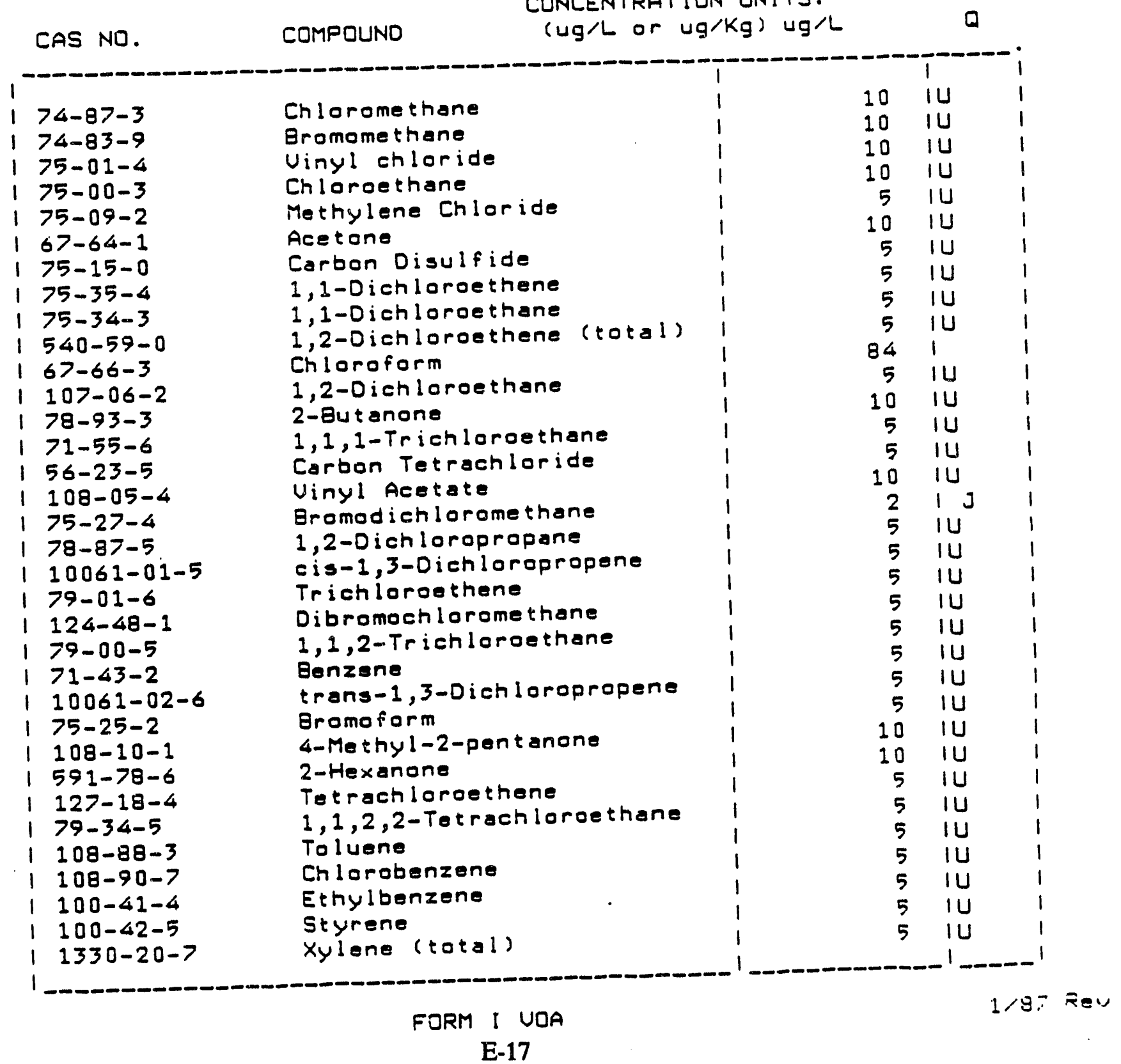


SAMPLE NO.

1

INORGANTC ANALYSIS DATA SHEET

Iab Name: TCT St. Iouis Contract: ERDTOSO2

Lab Code: TCT Case NO.: TOSO2 SAS NO.:

Lab Sample ID: $92006115^{10 \times 4-}$.

Matrix (soil/water): WATER

Level (low/med): LOW

Date Received: 09/16/92

$\&$ Solids :

0.0

Concentration Units (ug/L or $\mathrm{mg} / \mathrm{kg} \mathrm{drY}$ weight): UG/L

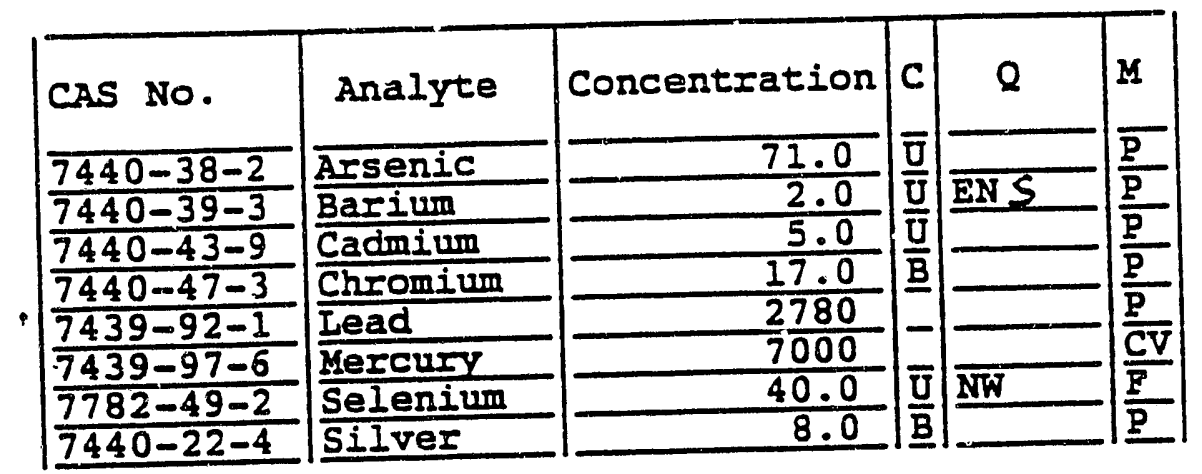

Color Before:

Color After:

Comments :
Clarity Before:

clarity After:
Texture:

Artifacts:

FORM I - IN

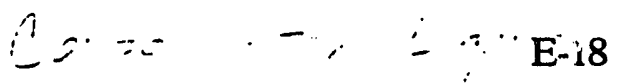


LaD NEmE: TEI-SI. LCUUIS Contract: EEDTCSO2

Lab Code: TCI Case No.: TOSO2 Sis No.:
EGaG Sample No.

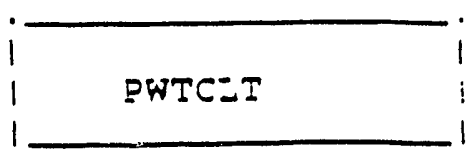

SDG NO.: PWTBT?

jample Marrix: (sol1/water'other) WATES

Extract Matrix: (water) WATER

Lab Sample ID: 92006115

Exerace vol: 5 (ml) MI

Lab File ID: $\quad$ G6125

Leve 1: (Low/med) LOW

Date Received: 09/16/92

* Mossture: not dec. dec.

Date of ZHE: $09 / 21 / 92$

Column: (nar/wide/pack) WIDE

Date Analyzed: $09 / 30 / 92$

\section{Dilution factor: 5}

CONCENTRATION TCLP MAXIMUM UNITS

CAS NO.

COMPOUND

(ug/I ) CONCENTRATION

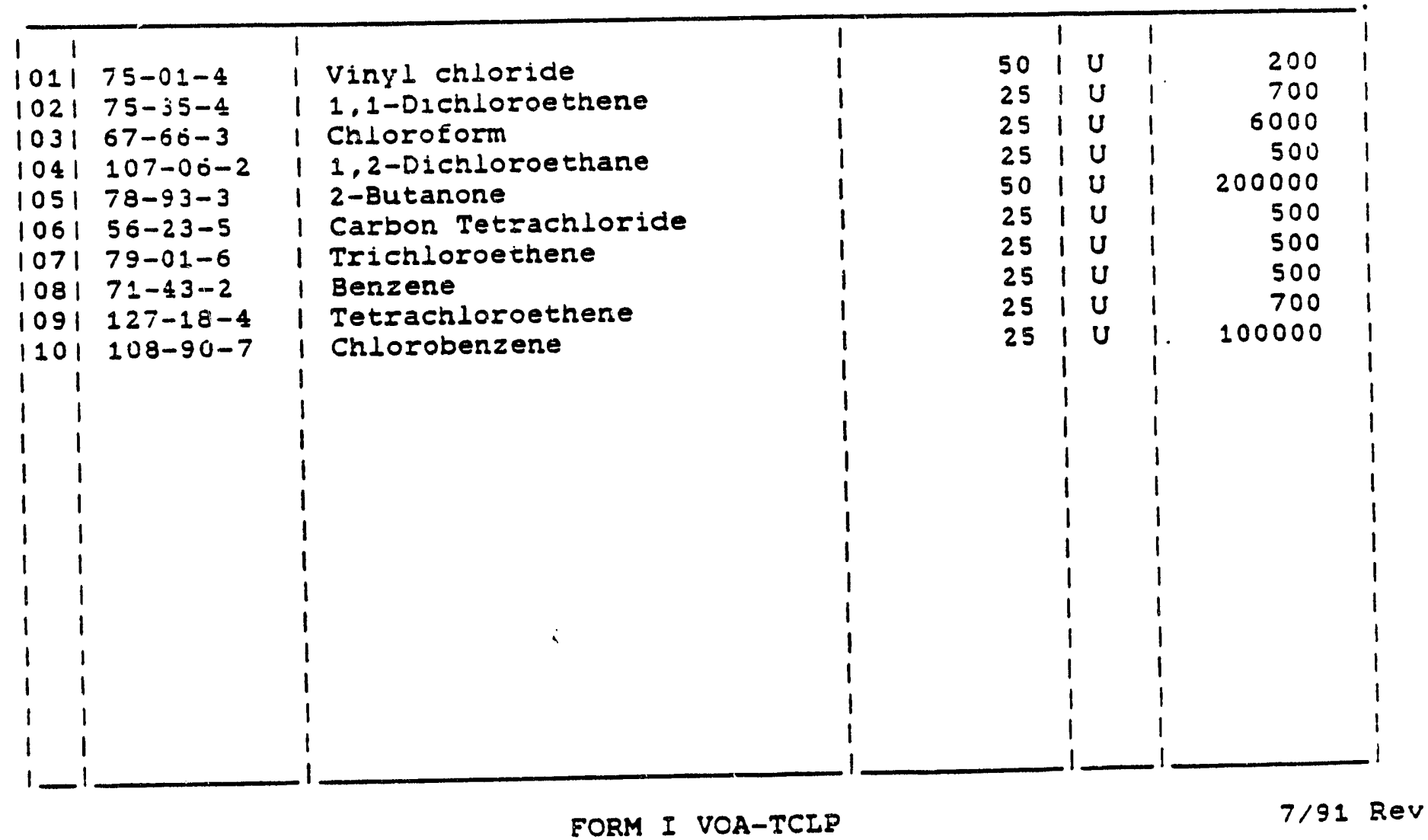


Lan Name: TCI-ST. LUUIS Cortrace: ERDTOSO2

Lav :Oode: TET Case No.: mosO2 SAS No.:
EGaG SEmple No.

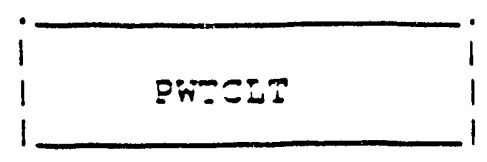

SDG NO.: PWTCII
Sample Matzix: (soil/water/other) HATER
Lab Sample ID: 92006115
Extract Matrix: (water) HATER
Lab File ID:
$>\$ 8532$
Ex!ra:t Vo!: 5100 (ml) ML
Date Received: $09 / 46 / 92$
Leve 1: (Low/med) LOW
Date of TCIP Ext. $09 / 21 / 92$
- Morsture: dec. not dec.
Date Extracted: $09 / 22 / 92$
Extraction: (sepr/Cont/Sonc) SEPF
Date Analyzed: $09 / 24 / 92$
GFC Cleanup: $\quad(H / N) \mathrm{N}$
pH: 11
Dilution Factor: 1
CONCENTRATION ICLP MAXIMUM UNITS
(ug/L) CONCENTRATION (ug/I)

EAS NO. COMPOUND

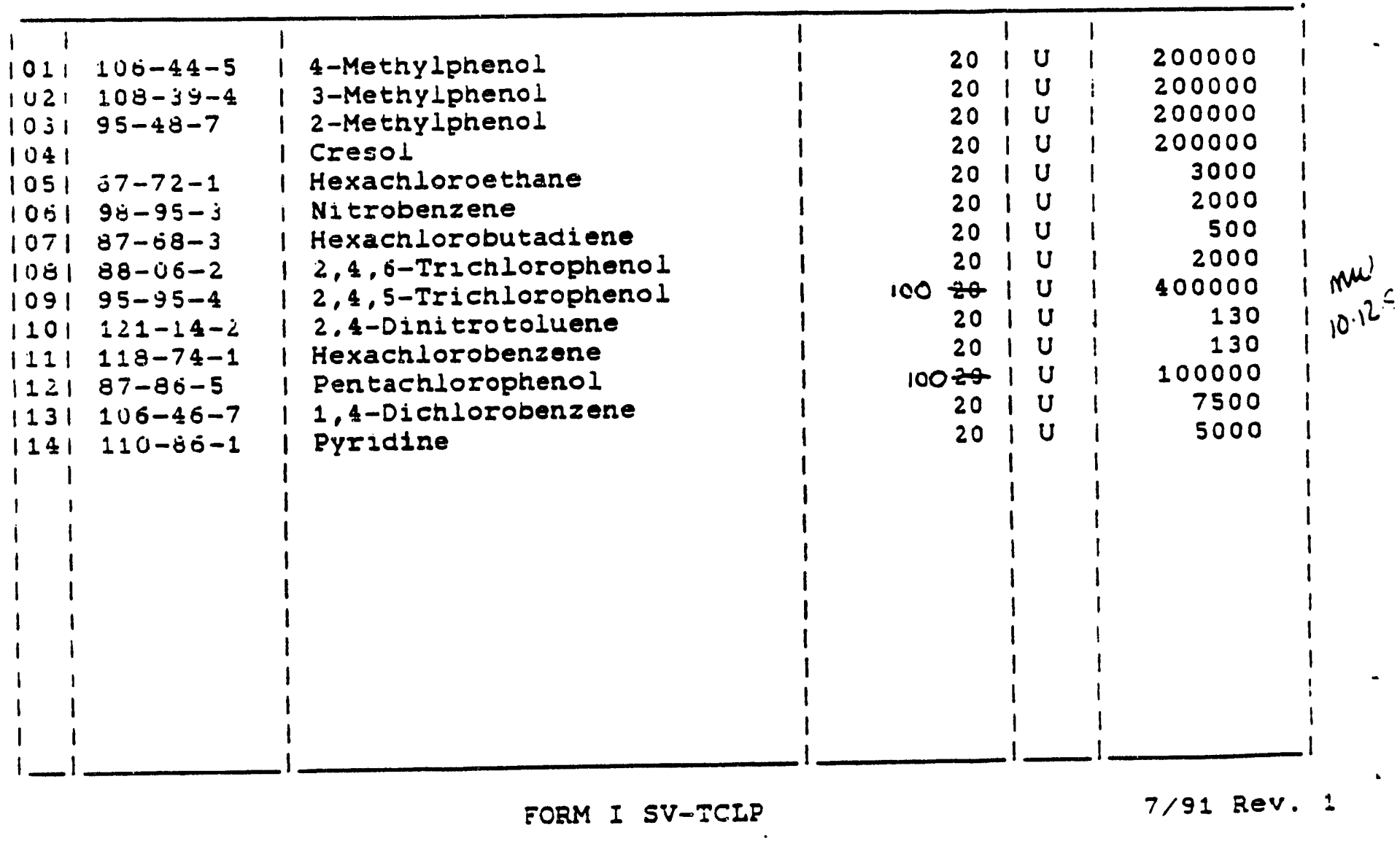


ORGANOCHLORINE PESTICIC

Lab Name: $\frac{\text { I.T ST Louls }}{\text { Lab Code: } \text { IT Case No.: TOS.02 }}$ SAS No.: $\frac{\text { EGaG Sample No. }}{\text { PWTCLT }}$

Sample Matrix: (soil/water/other) weTES Lab Sample iD: $92006-115$

Extract Matrix: (water) LaIER Lab file ID:

Extract vol: $500(\mathrm{~mL}) \mathrm{mL} \quad$ Date Received: $9-16-92$

Leve1: (low) Low Date of TCLP Extraction: 9.2192

* Moisture: not dec. $N A$ dec. $N A$ Date Extracted: $9-32-92$

Preparatory Extraction: (SepF/Cont) SEPF Date Analyzed: $9-24-92$

GPC Cleanup: (Y/N) N PH: $11.0 \quad$ Dilution Factor: 1.

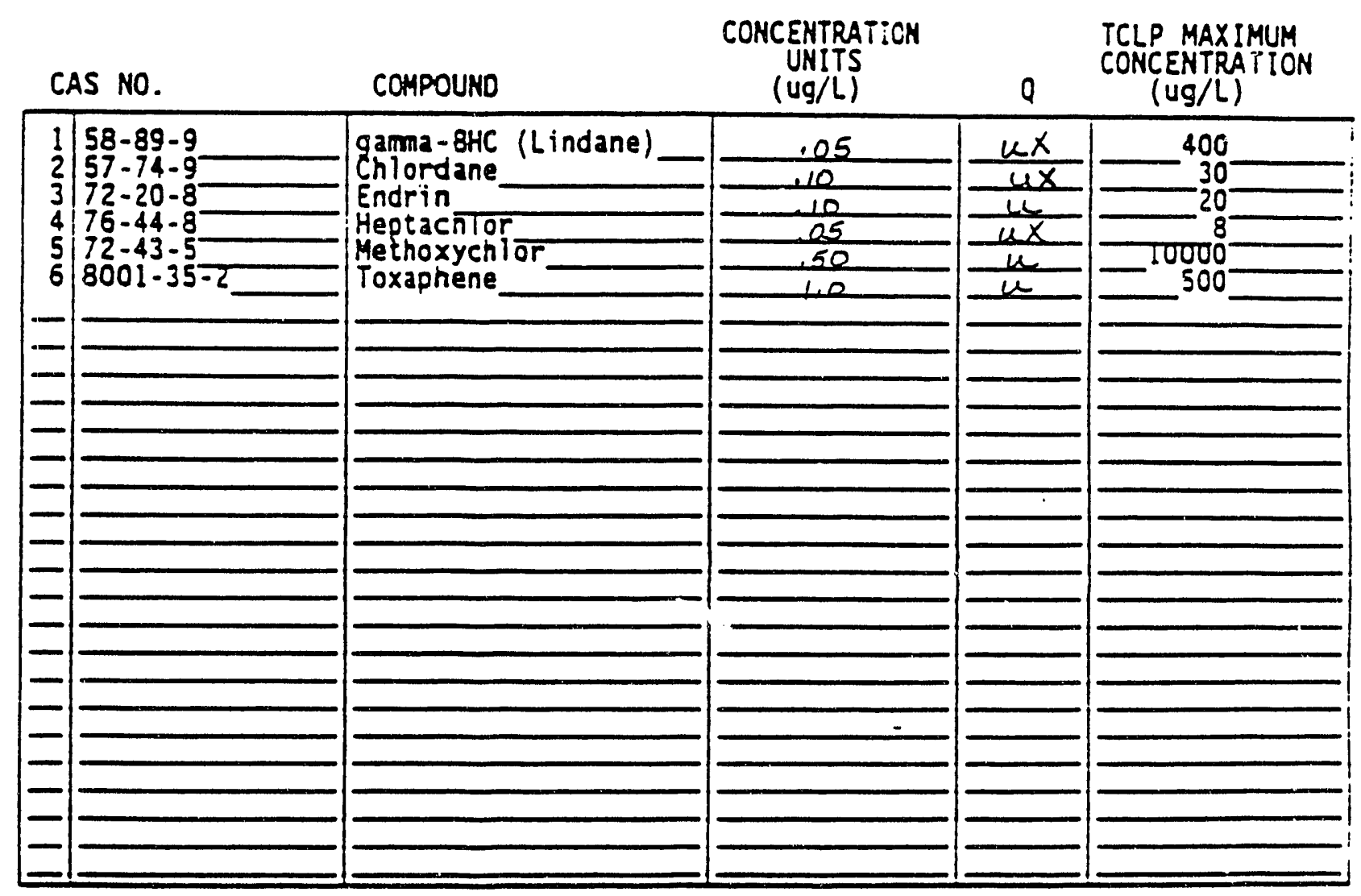

$X$ - see 1-100 DILUTION for sample DL

FOPF I OCPEST-TCLP

7/91 Rev. 


\section{ORGANOCHLORINE PESTICIDE ANALYSIS DATA SHEET}

EGág Sample No.

Lab Name: ICT ST Lou 15 contract: ERCTOSO2 PWTCLT DL

Lab Code: ICT Case No.: TOS.02 SAS No.:

SOG NO.: PNTELT

Sample Matrix: (soil/water/other) WETES Lab Sample ID: 92006115

Extract Matrix: (water) WATER

Extract vol: 500 (mL) $\mathrm{ml}$

Leve 1: (10w) Low

* Hoisture: not dec. NA dec. NA

Preparatory Extraction: (SepF/Cont) SEPF

GPC Cleanup: (Y/N) $\mathbb{N}$ PH: $\mathbb{L}$.
Lab File ID:

Date Received: $\quad 9-16-92$

Date of TCLP Extraction: 9.2192

Date Extracted: $9-32-92$

Date Analyzed: $\frac{9-24-92}{100}$

Dllution Factor: 100 .

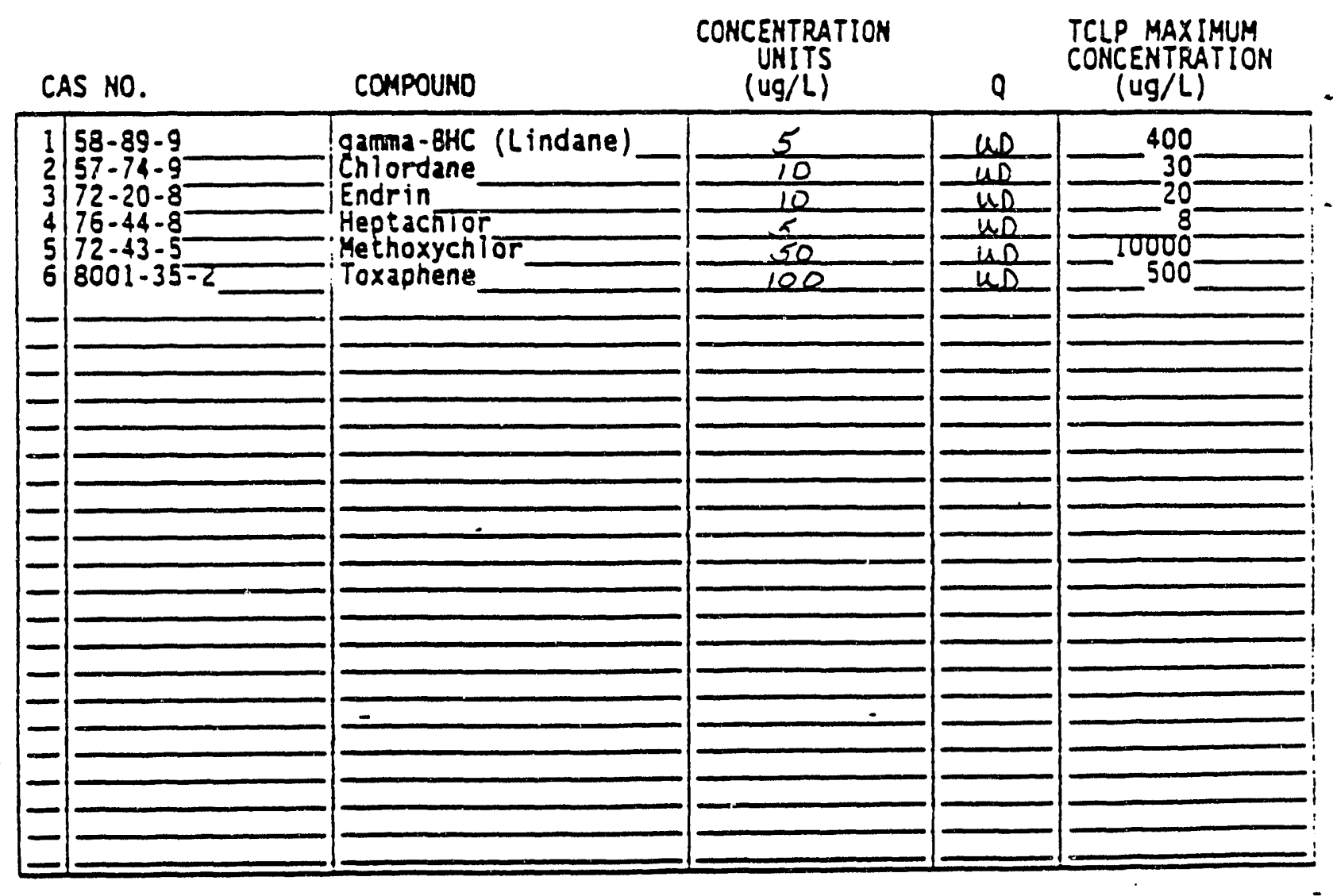

FOPH 1 OCPEST-TCLP

7/91 Rev. 


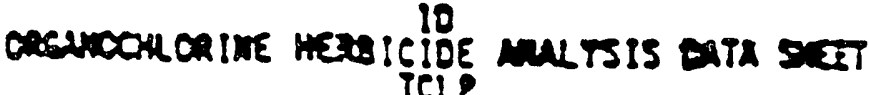

Ees smole No.

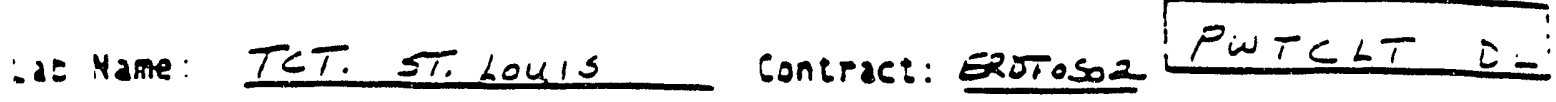

LaE Cooe TET Gase Hc.: TESCZ SAS Ho.: NA SO6 Ho.: PWTCLT

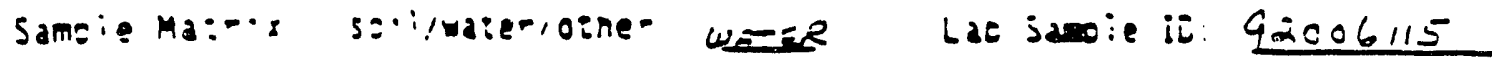

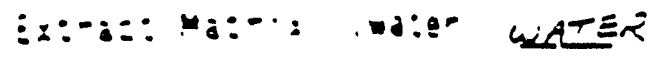

$\vdots::-a:: \forall:$ SES im. ML

La: $:: \therefore:$ : $:$ NA

-ere' in Low

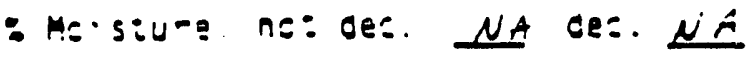

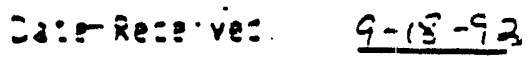

Ex:paz:isr: (hers: Hers

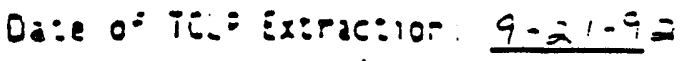

GPe Cieanue: (T/N; $\mathbb{N}$ PH: 13

Oaie Extr ited: 9.22 .92

Da:e Anaiged: $\quad 9-2 \leq .92$

Dilution Factor: 25.0

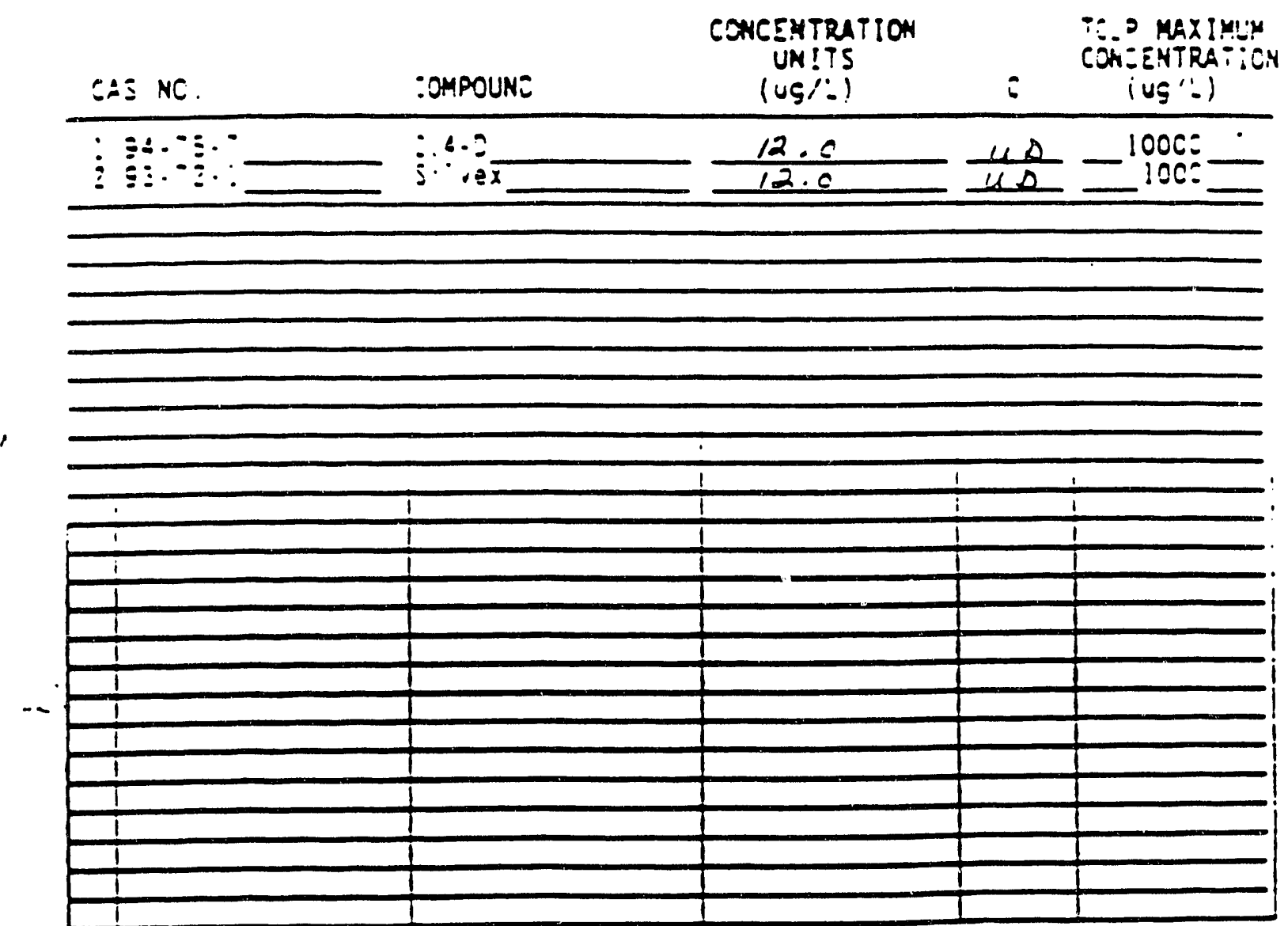

FORH I OCHERB-TCLP

T/91 Rer. 
November 5, 1992 9259-00009

Ms. Donna Kirchner

Field Data Coordinator

ERP Administrative Record

and Document Control

EG\&G Idaho, Inc.

P.O. Box 1625

Idaho Falls, ID 83415-3904
: j

1908 Innerbelt Bisiness Ceater Drive

St. Louis. .:issouri 63114-5700

PLone (314) 426-0880

Ua

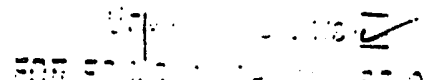

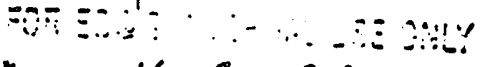

जi: $11-C_{2}-92$

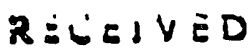

Noy 6 199?

E:YVIRONHE.TAL RESTORALIOH DEFT.

Re: Data Package for Task Order 15 Under Subcontract C92-170021

Dear Ms. Kirchner:

Enclosed is a data report for the analysis of samples received by TCT-St. Louis under subcontract No. C92-170021/Task Order 15, (TOS No. ERD-TOS-02, MOD 2). This report contains analytical sample data for samples collected from treatability studies being conducted at the Test Reactor Area (TRA). The samples were anatyzed specifically for TCLP metals, TCLP pesticides, TCLP herbicides, TCLP volatiles and corrosivity.

The samples were received by TCT-St. Louis on October 2, 1992 with a stated turn-around time of 35 days from receipt of the last sample in the SDG. The due date is November 6 , 1992.

The EG\&G site codes, corresponding File I.D.'s, TCT-St. Louis laboratory sample numbers for each sample delivery group are shown in the following tables.

SDG TUPFP1

TCLP (VOLATIIES, PESTICIDES, HERBICIDES, SEMTVOLATILE, AND METALS) EG\&G SITE ID FIIE ID TCT LAB NO. DATE COLIECTED

PWTUPFT1

PWTLPFT2

PWTUIOXT1

PWTUIOXI2

\section{TUPFT1}

TUPFT2

UIOXT1

UIOXT2
92006648

92006650

92006652

92006654

TCT LAB NO.

92006649

92006651

92006653

92006655
9/30/92

9/30/92

9/30/92

9/30/92
SDG TUPFC1 - CORROSIVITY EG\&G STTE ID

PWTUPFC1

PWTUPFC2

PWTUIOXC1

PWTUIOXC2
TUPFC1

TUPFC2

UIOXC1

UIOXC2

\section{DATE COLLECTED}

9/30/92

9/30/92

9/30/92

9/30/92 
TCT-St. Louis

9259-00009

page 2

For reporting purposes, the contract number is ERDTOSO2 and case number TOSO2. All samples were analyzed and reported per the requirements of C92-170021 TASK ORDER NO. 15, ERD-TOS-02 MOD 2

A copy of the original chain-of-custody was mailed to Donna Kirciner on October 19, 1992.

Several corrections were made to the chain of custody after phone conversations with Isabel Anderson on October 2, 1992. TCLP pesticides and herbicides were added to the first four samples. The last four samples were changed to corrosivity. A limited amount of filter material was available for analysis. Ms. Anderson informed me that additional sample from the corrosivity bottle could be used to perform the requested analyses. The priority for analysis should be: 1 - metals with matrix spike, 2 - BNA with manix spike, 3 - VOA with matrix spike, 4 - pesticide and herbicide with matrix spike.

\section{TCLP METALS}

The samples were analyzed within the required holding times. A CLP equivalent data package has been prepared. The TCLP metals samples are contained in SDG TUPFT1. This SDG contains several waste matrix types. A matrix spike was performed on each waste type, TUPFT1 and UIOXT1. A duplicate anałysis was also performed for sample UIOXT1.

\section{CORROSIVITY}

The four samples were analyzed by Method 1110 Corrosivity Toward Steel. The corrosivity results are included at the end of the case narrative.

\section{TCLP BNA}

The samples were analyzed within the required holding times. A CLP equivalent data package has been prepared. The TCLP BNA samples are contained in SDG TUPFP1. A matrix spike and a matrix spike duplicate were performed on samples TUPFT1 and UIOXT1. Several surrogate compounds were not recovered within acceptabie limits in the TCLP blank and the method blank. All surrogate recoveries were acceptable in the samples. Non-target compound contamination was observed for the TCIP blank. The non-target compounds should not reduce the validity of the TCLP sample analyes. The non-target compound contamination was discussed with Rod Grant. Insufficient sample was available to re-extract the samples. 
TCT-St. Louis

9259-00009

page 3

\section{TCLP PESTICIDES}

The samples were analyzed within the required holding times. A CLP equivalent data package has been prepared. The TCLP Pesticides are contained in SDG TUPFP1. A matrix spike has been performed on sample TUPFT1. A matrix spike and a matrix spike duplicate has been performed on sample UIOXT1.

\section{TCLP HERBICIDES}

The samples were analyzed within the required holding times. A CLP equivalent data package has been prepared. The TCLP Herbicides are contained in SDG TUPFP1. A matrix spike was performed on sample TUPFT2 A matrix spike and a matrix spike duplicate were performed on sample UIOXT2. The matrix spikes were not recovered for any of the matrix spikes for these samples. The laboratory control sample had good recovery demonstrating acceptable method performance. A sample matrix effect was suspected. Due to insufficient sample volume the samples could not be re-extracted and reanalyzed.

\section{TCLP VOLATILES}

The sampies were analyzed within the required holding times. A CLP equivalent data package has been prepared. The TCLP volatiles are contained in SDG TUPFP1. A matrix spike was pexformed for sample TUPFT1. A matrix spike and a matrix spike duplicate were performed for sample UIOXT1. The recovery of 2-Butanone was within SW-846 limits but was slightly below the EG\&G TCLP range for sample UIOXT1. Good recoveries were obtained in the laboratory control sample. The LCS was injected two minutes after the 12 hour time limit from the BFB tune.

This work will be invoiced under purchase order number C92-170021 and TCT-St. Louis project number - 9259-00009.

If you have any questions concerming this data reporh please call me at (314) 426-0880.

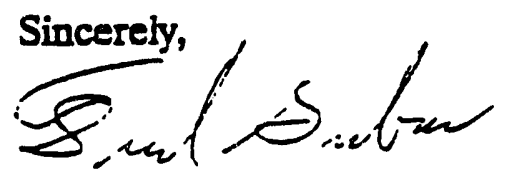

Fred Grabau

Project Manager 


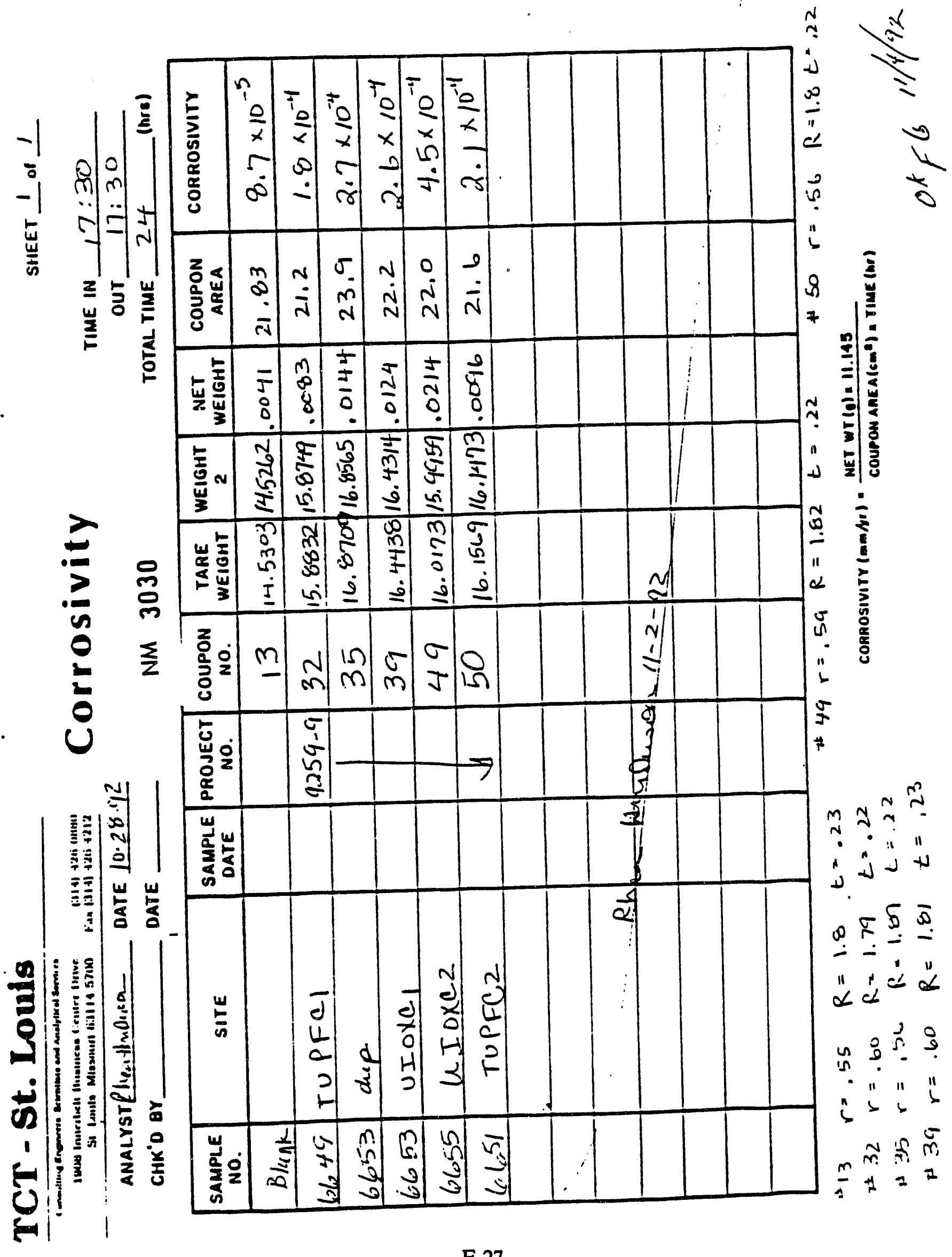

E-27 
$1 \AA$

VOLATILE OREANICS ANALYSIS DATA SHEET

TCLP

EsaG Sample No.

iab Namo: Ti:T-ET. LOUIS

Contrafs: ERDTOSO2

Lab Coce: TCT

Case $10 .:$ TOSO2 SAS NO.:

TUPET1

sample Matrix: (soil/water/other) SOIL

Extract Matrix: (water) . WATES

Extrace vol: 5 (m)

Lab Sample ZD: 92006648

Level: (Low/med) LOW

Lab File ID: UH1400

* Moisture: not dec. dec.

Date Received: 10/02/92

Column: (nar/wide/pack) FĩDE

Date of 2H:E: $10 / 07 / 92$

Date Analyzed: $10 / 19 / 92$

Dilution iactor: 5

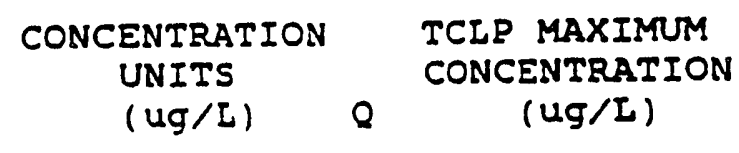

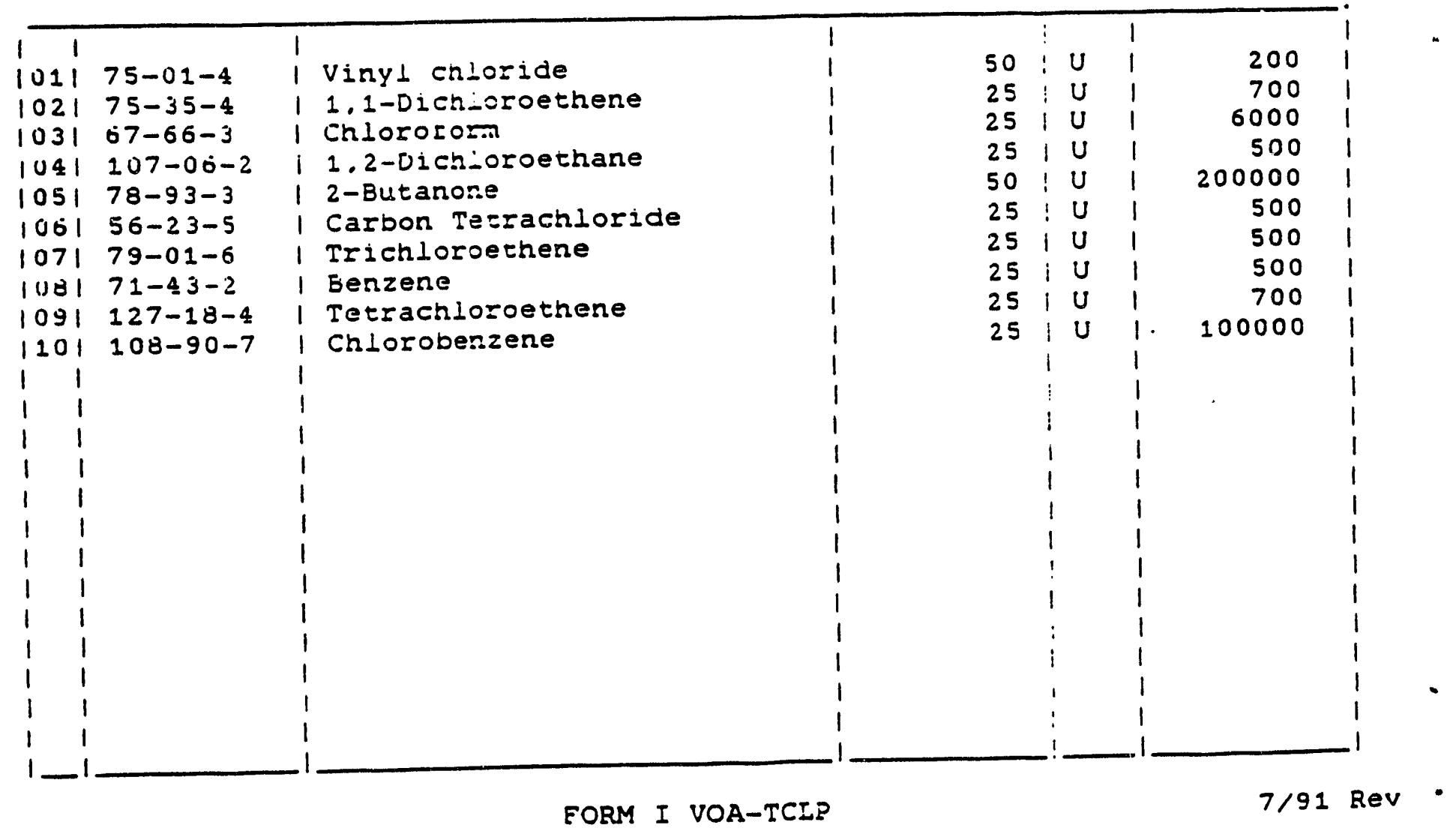


EGäG Sample No.

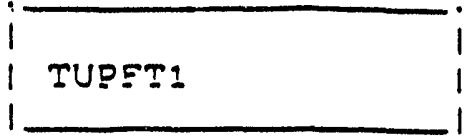

Lab Name: 'L"'r-s"l', Louls

Contzacs: ERDTOSO2

Lab Cocte: TCT

Case No.: TOSO2 SAS NO.:
Sample Matri:: (soli/water/other) WIPES

Extract Matrix: (water) WATER

Extract vol: 500 (ml) ML

Level: (Low/med) Low

\$ Molsture: dec. not dec.

Extraction: (Sepi/Cont/Sone) SEPE

GPC Eleanup: $\quad(Y / N) N$

$\mathrm{pH}: 5$

CAS NO.

COMPOUND
Lab Sample ID: 92006648

Lab File ID:

$>08649$

Date Received: $10 / 02 / 92$

Date of TCLP Ext. 10/07/92

Date Extracted: $10 / 10 / 92$

Date Analyzed: 10/20/92

Dilution Factor: 1

CONCENTRATION TCLP MAXIMUM UNITS

(Ug/L)

Q CONCENTRATION (Uğ/L)

\begin{tabular}{|c|c|c|c|c|}
\hline 1 & & 1 & & 1 \\
\hline 1011 & $106-11-5$ & 1 & 4-Methylphenol & l \\
\hline $10 \geq 1$ & $108-1 y-1$ & 1 & 3-Methylphenol & 1 \\
\hline 1031 & $95-48-7$ & 1 & 2-Methy lphenol & 1 \\
\hline 1011 & & 1 & Eresol & 1 \\
\hline 1051 & $67-72-1$ & 1 & Hexachloroethane & 1 \\
\hline $\mid 061$ & $y 8-\because s-j$ & 1 & NItrobenzene & 1 \\
\hline 1071 & $87-68-3$ & 1 & Hexachlorobutadiene & 1 \\
\hline $\mid 081$ & $8 y-110-2$ & 1 & 2.1.0-Trachlorophenol & 1 \\
\hline $\log 1$ & $y b-y b-4$ & 1 & 2.4.5-Trichlorophenol & 1 \\
\hline $\mid 101$ & $121-11-2$ & 1 & $2.1-D 2 n 1=z$ otoluene & 1 \\
\hline$|11|$ & $118-74-1$ & 1 & Hexachlorobenzene & 1 \\
\hline 1221 & $87-3 \dot{3}$ & 1 & Pentachlorophenol & 1 \\
\hline 1131 & $106-16-7$ & 1 & 1,4-Dichlorobenzene & 1 \\
\hline 1121 & $110-8 b-1$ & 1 & EYrzdine & 1 \\
\hline 1 & & 1 & & 1 \\
\hline 1 & & 1 & & 1 \\
\hline 1 & & 1 & & 1 \\
\hline 1 & & 1 & & 1 \\
\hline 1 & & 1 & & 1 \\
\hline 1 & & 1 & & \\
\hline 1 & & 1 & & \\
\hline 1 & & 1 & & 1 \\
\hline 1 & & 1 & & \\
\hline 1 & & 1 & & \\
\hline
\end{tabular}

FORM I SV-TCLP

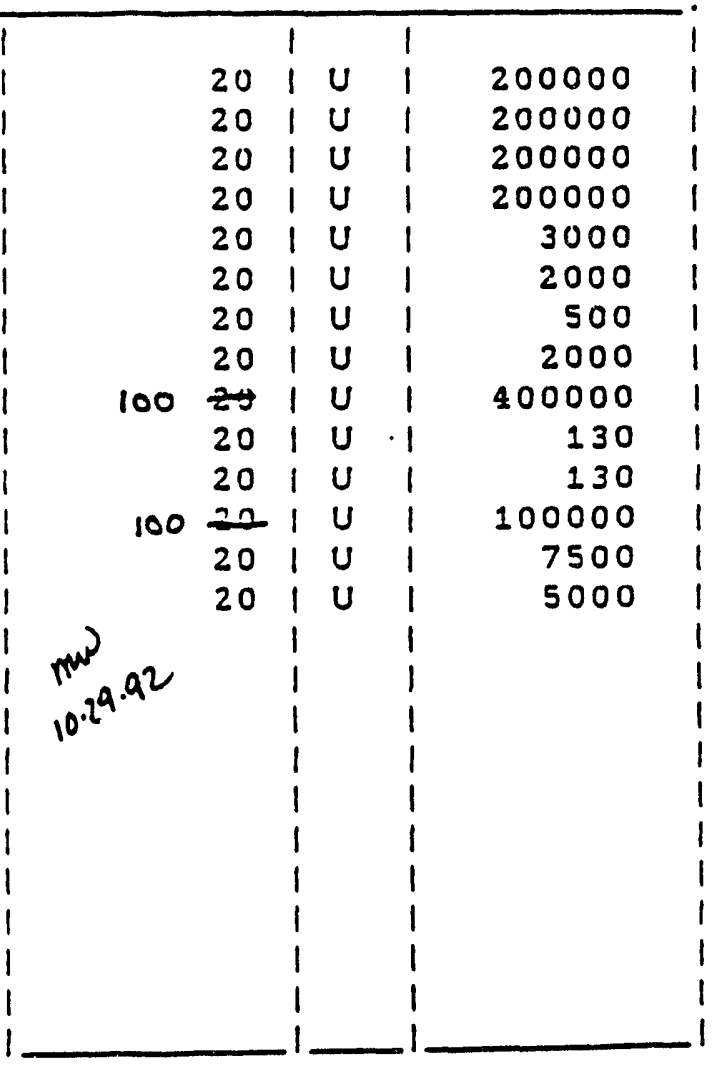

7/91 Rev. 1 


\section{ORGANOCHLORINE PESTICIDE ANALYSIS OATA SHEET}

EgaG Sample Ho.

Lab Name: TCT-ST. LOUSS Contract: EROT0:02

TUPFTI

Lab Code: TCT Case No.: TOSO2 SAS No.:

SOG NO.: TUPFPI

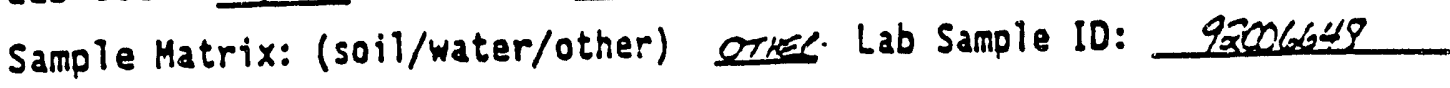

Extract Matrix: (water) wAIER

Extract vol:

Lab file ID:

Level: (low)

Date Received: $10-2-92$

\% Moisture: not dec. NA dec. NA Date Extractad: 10-13- $2 Z$ Preparatory Extraction: (SepF/Cont) SEFE Date Analyzed: $\$ 0.22-92$ GPC Cleanup: $(Y / N) N$ PH: $\Sigma$ Dilution Factor: 1

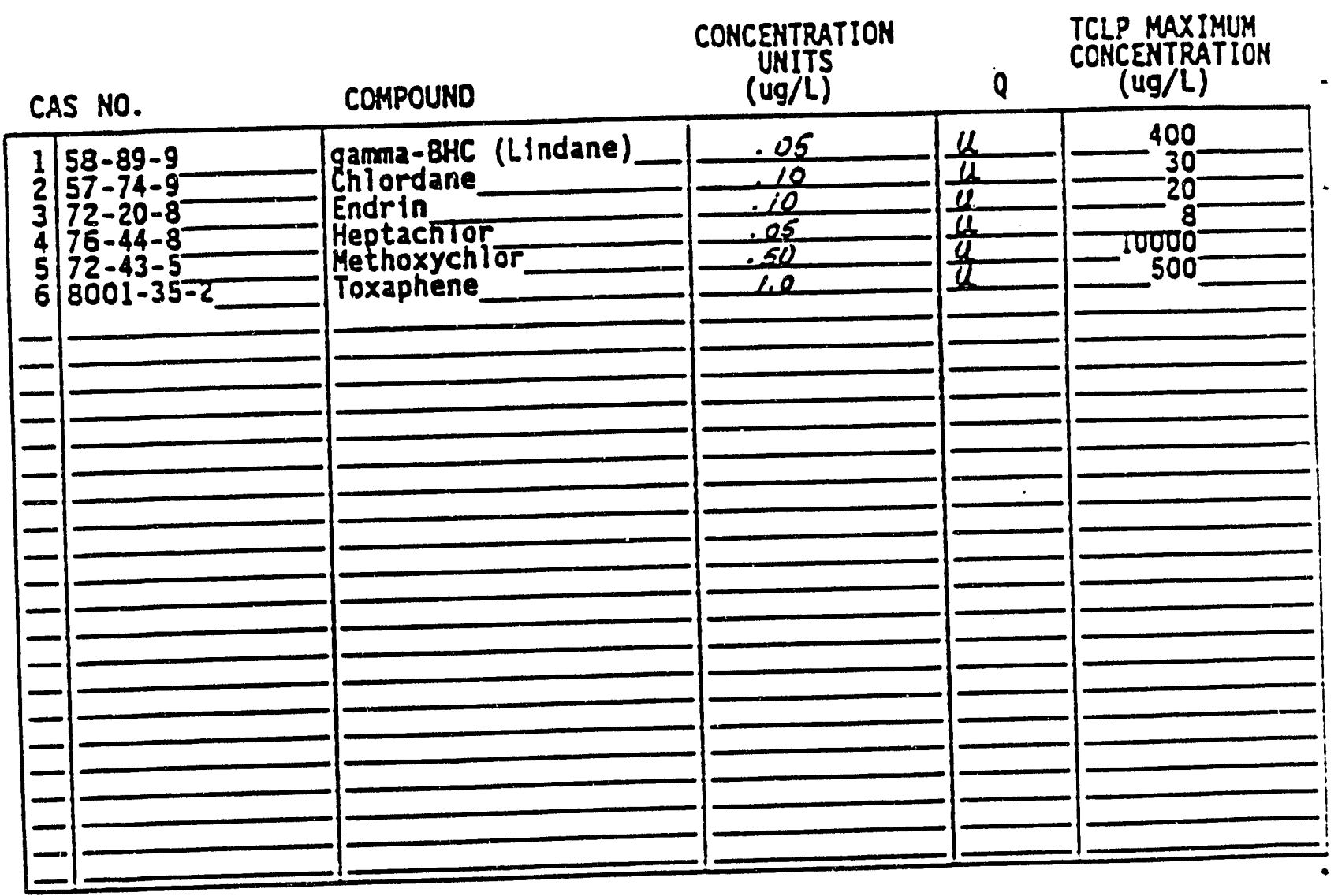




\section{ORGAHOCHLORIXE HERBICIDIDE AMULYSIS OATA SHEET}

EGas Sample No.

Lab Name: $T_{C T}, 5 T_{1}$ Louls Coniract:ERDTOSC2 TUPFTI

LaO Coce: TCT Case No.: TOSOz SAS Mo.: NA SOS No.: TUPFPI

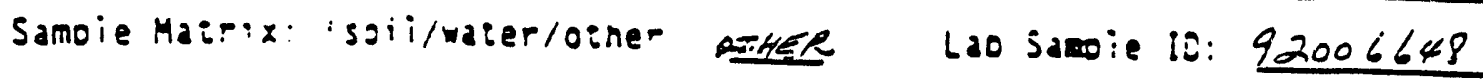

Extrac: Matrix: (watar) wher

Ro-29.72Exirac: vo:: 250 (mL: ML

Levei: (iow) Low

\# Moisture: not dee. LA des. NA

Extraction: (Hert) HeRB

GPC Cleanup: $(\dot{Y} / \mathrm{N}) \perp \mathrm{N}$ PH: 5

Las isie IS: NA

Date-reseives: $10-2-92$

Dace of TCLP Extraction: $10-\not 4-9210.29 \cdot 9 \mathrm{i}$

Date Extractes: $10-16.52$

Date Analyzed: $10-26-92$

Dilution Fac:or: 1,0

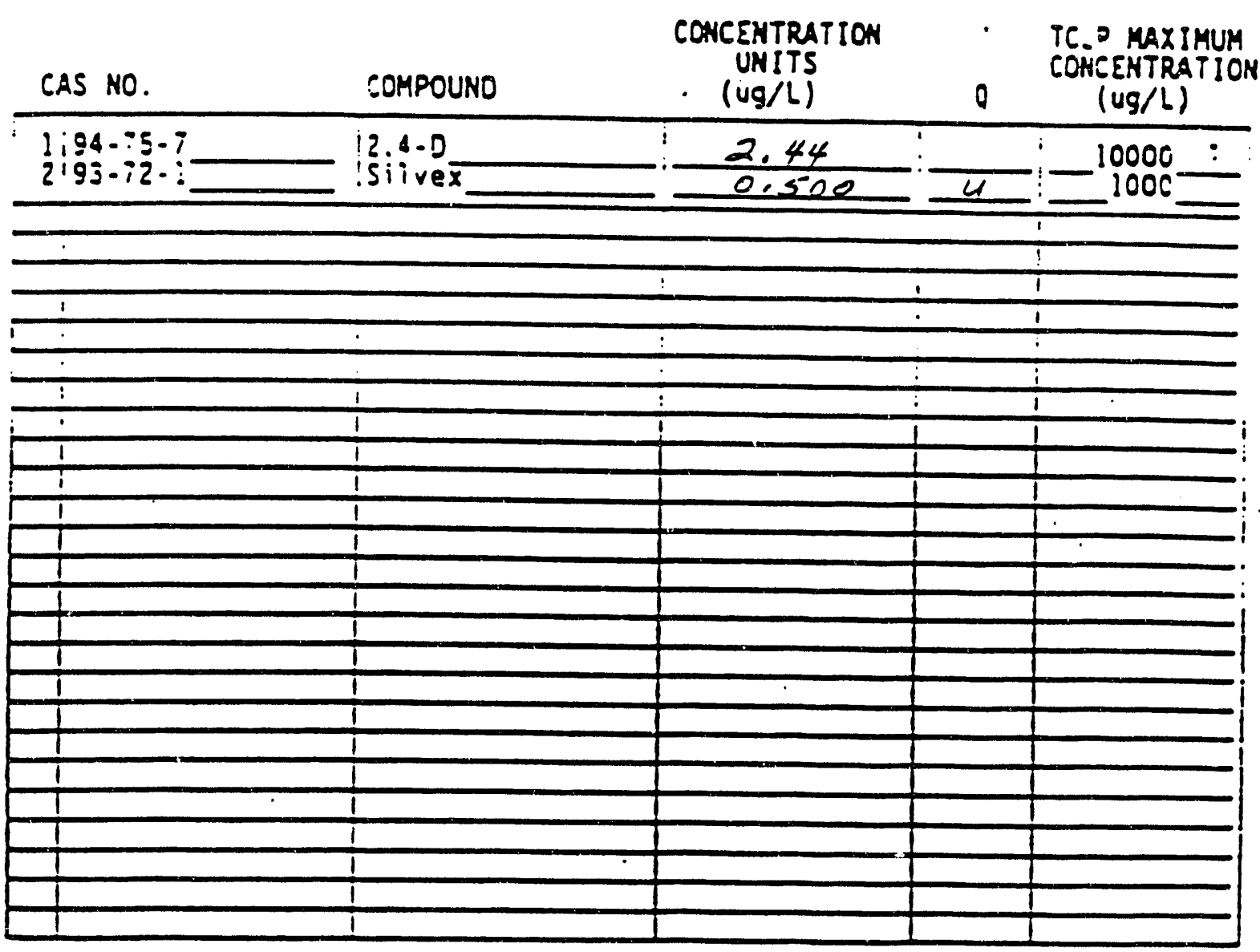

FORA I OCHERB-TCLP

T/91 Rey. 
1

IMIORGANIC ANALTSIS DATA SIEET

Lab Name: TC, St. Louis Contzact: ERDTOSO2

Lab Code: TCT

Cage No.: TOSO2

Matrix (soil/water): WATER

SAS NO.:

Lab Sample ID: 92006648

Level (Low/med): LOW

Date Received: 10/02/92

SDG NO.: TUPPTI

of Solids:

0.0

Concentration Onits (ug/I or mg/kg dry weight): $0 G / \mathrm{L}$

$\frac{7 \text { CAS NO. }}{\frac{7440-38-2}{7440-39-3}}$

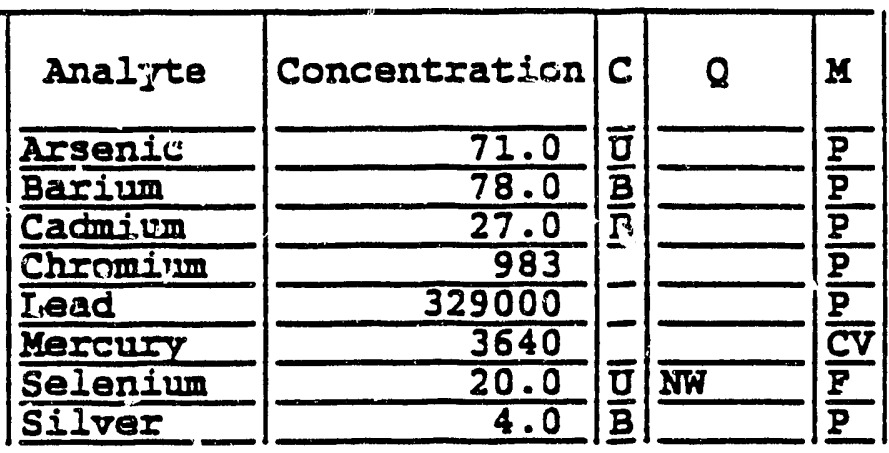

Colcr sefore: colortess

Color After: COLORIESS

Comments:
SAMPIE NO.

TUPETI 
EG\&G Sample No.

Lab Name: TCT-ST. LOUIS

Contrac: : ERDTOSO2

Lab Code: TCI

Case No.: TOSO2 SAS NO.:

TUPFT2

sample Mas=1x: (so11/water/other) SOIL

Exeract Matrix: (water) WATER

Lab Sample ID: 92006650

Extract vol: 5

$(m+)$

Lab File ID:

UH1402

Level: (low/med) LOW

Date Received: $10 / 02 / 92$

* Moisture: nor dec.

dec.

Date of ZHE: $\quad 10 / 07 / 92$

Column: (nar/wide/pack) WIDE

Date Analyzed: $10 / 19 / 92$

Dilution factor: 5

CONCENTRATION
UNITS

TCLP MAXIMUM

CAS NO.

COMPOUND

$(u g / L)$

CONCENTRATION

Q $(u g / L)$

\begin{tabular}{l|l}
\hline 1011 & $75-01-4$ \\
10021 & $75-35-4$ \\
1031 & $67-66-3$ \\
1041 & $107-06-2$ \\
1051 & $78-93-3$ \\
1061 & $56-23-5$ \\
1071 & $79-01-6$ \\
1081 & $71-4-3-2$ \\
1091 & $127-18-4$ \\
1101 & $108-90-7$ \\
1 & 1 \\
1 & 1 \\
1 & 1 \\
1 & 1 \\
1 & 1 \\
1 & 1 \\
1 & 1 \\
1 & 1 \\
1 & 1 \\
1 & 1 \\
1 & 1 \\
1 & 1
\end{tabular}

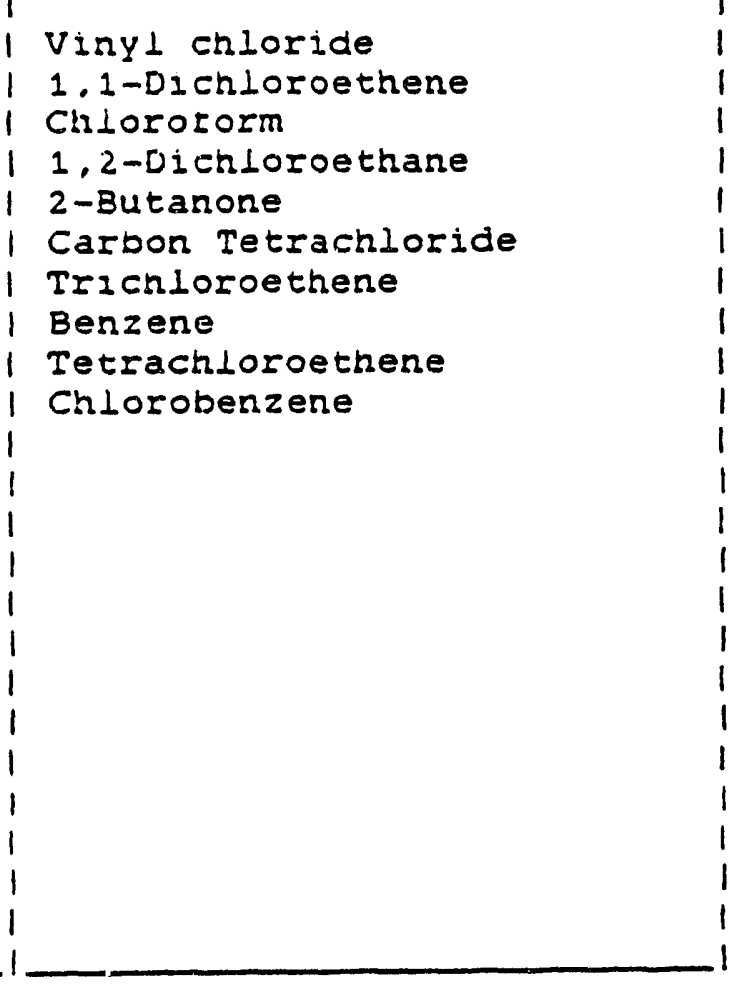

FORM I VOA-TCLP 
Lab Nams: "Wr-ST. LOUIS

Contrac: : EDDTOSO2

Lab Code: TCT

Case No.: TOSO2 SAS NO.:

EGÁ Eampie No.

\section{TUPE:=}

Sample Matzlx: (s011/water/other) WIPES

Lab Sample ID: $Q: J 06650$

Extract Matrix: (water) WATER

Lab File ID: $\quad>08650$

Extrac: yol: 500 (ml) ML

Date Received: :2/02/92

Level: (Low/med) LOW

Date of TCIP Ex $=.10 / 07 / 92$

* Moisture: dec. not dec.

Date Extracted: 10/:2/92

Extraction: (Sepf/Cont/Sonc) SEPF

Date Analyzed: $13 / 20 / 92$

Gre Cleanud: $\quad(Y / N) N$

$\mathrm{pH}: 5$

Dilution Factor: :

CONCENTRATION
UNITS

SAS NO.

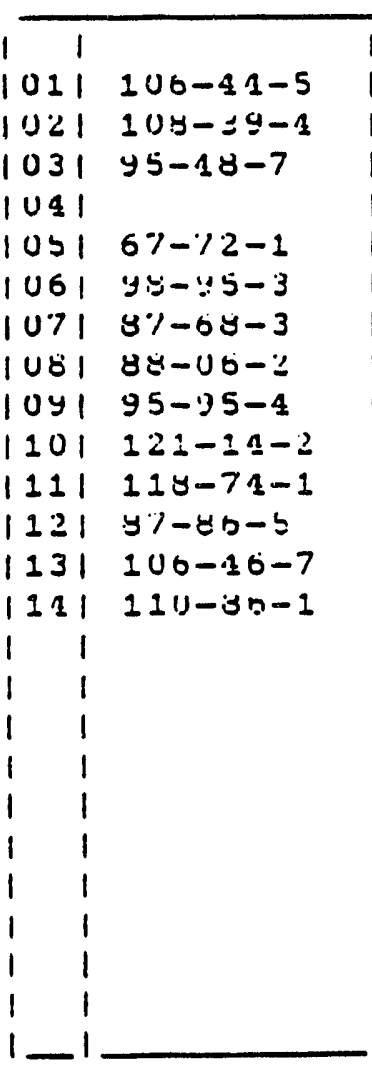

COMPOUND

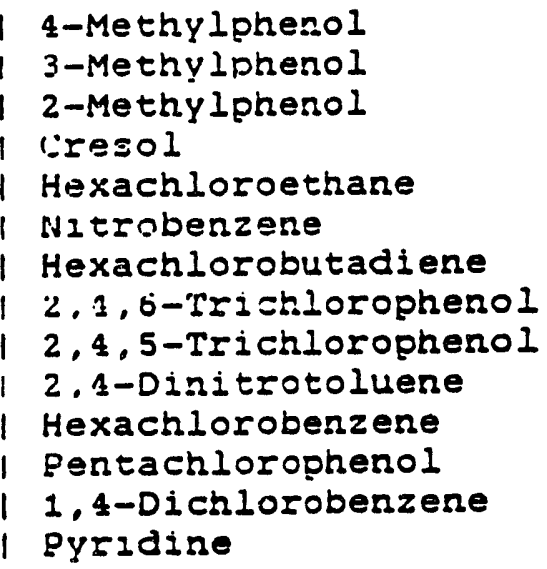

TCLP MAXIMUM CONCENTRATION (ug /L)
200000 200000 200000 200000 3000 2000 500 2000 400000 130 130 100000 7500 5000

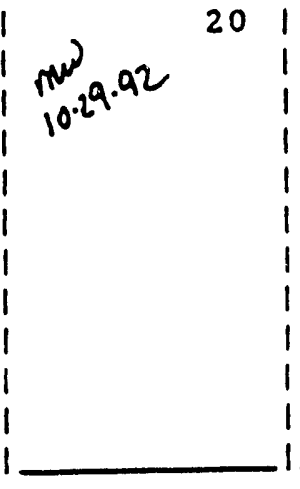

7/91 ReV. 1 
EGas Sanole No.

Lab Name: TCT. ST, Louls Contract:ERSTOSO=

TUPFT2

LaD Coce: TeT Gase No.: TOSOz SAS No.: NA S00 No.: TUPFPI Samoie Matr:a issilwater/oiner ozire La samoie 10: Q2006650

Exbrac: Matrix: (water) wTER

Exirze: vo:: 500 (ML: ML

Levei: (iow) Low

Las bite is: NA

* Moisture: not des. $L A$ dec. $N A$

Datereceives: $10-2-92$

Extraction: (Hert) HeRB

GPC Cleanup: $(\dot{Y} / \mathrm{H}) \mathbb{N} \mathrm{PH}: \underline{5}$

Date of ICLP Extrac:ion: $\langle 0-7-92$

Oaie Extracted: 10-14-92

Date Analyzed: $10-26-92$

Dilution Factor: 1.0

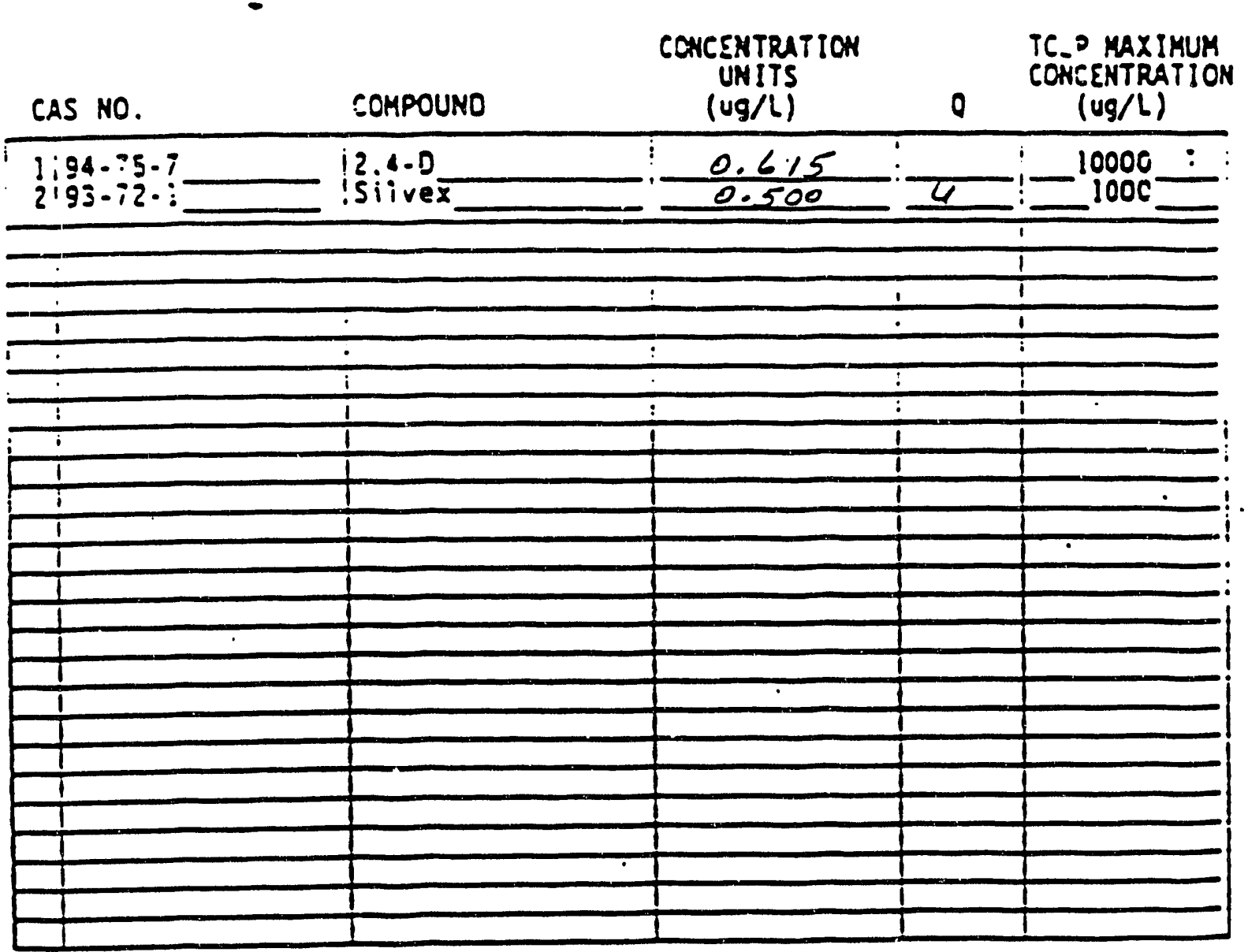




\section{ORGANOCHLORINE PESTICIDE ANALYSIS OATA SHEET TCLP}

EGaG Sample No.

Lab Name: TCT-ST. LOUTS Contract: EROTOSaA

TUPFT 2

Lab Code: ICT Case Mo.: TOSO2 SAS No.:

SOG NO.: TUPFPI

Sample Matrix: (soil/water/other) ortes Lab Sample ID: 92006650

Extract Matrix: (water) WATER

Lab Flle ID:

Extract vol: $\$ 0$ (mL) al

Date Received: 10-2-92

Level: (10w)

Date of TCLP Extraction: 10-7-92

* Moisture: not dec. NA dec. NA Date Extracted: 10-13-92

Preparatory Extraction: (SepF/Cont) SEPE

GPC Cleanup: (Y/N) $\mathbb{N}$ PH: $\underline{\Sigma}$

Date Analyzed: 10-23-92

Dilution Factor: 1

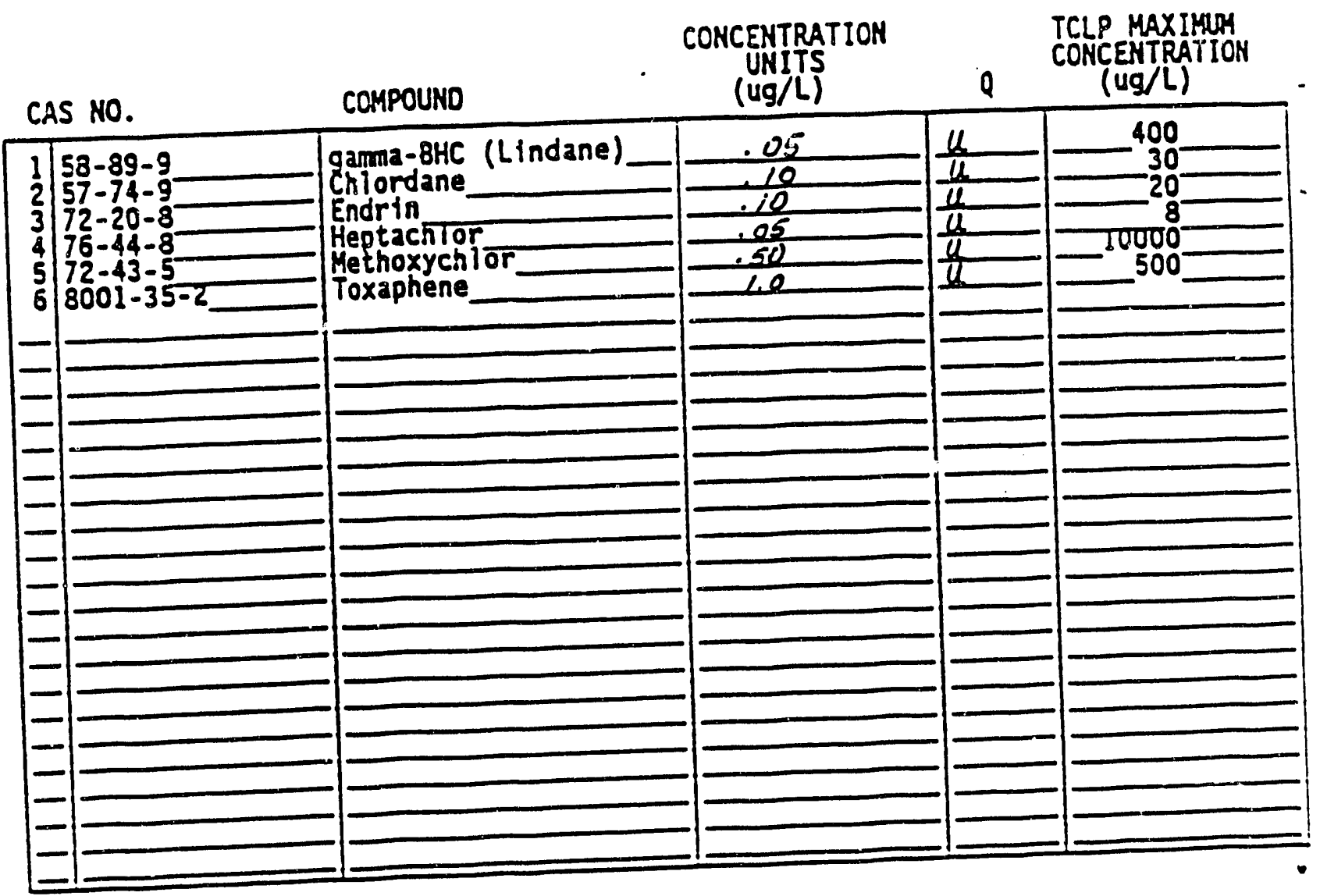

FORM 1 OCPEST-TCLP

7/91 Rey. 
INORGANIC ALAITSIS DATA SEEET

Lab Name: TCI St. Louis

Lab Code: TCT

Case No.: mos02

Contract: ERDTOSO2

\section{TUPFT2}

Matrix (soil/water): WATER

SAS NO.:

SDG NO.: TUPFT1

Iab Sample ID: 92006650

Level ( low/med): IOW

Date Received: 10/02/92

\& Solids:

0.0

Concentration Units (ug/I or $\mathrm{mg} / \mathrm{kg} d r$ weight): $U G / L$

\begin{tabular}{|c|c|c|c|c|c|}
\hline CAS NO. & Analyte & Concentration & c & $Q$ & $M$ \\
\hline$\frac{7440-38-2}{\frac{7440-39-3}{740-43-9}} \frac{74}{\frac{7440-47-3}{7439-92-1}} \frac{7439-97-6}{\frac{7782-49-2}{7440-22-4}}$ & $\begin{array}{l}\text { Arsenic } \\
\text { Barium } \\
\text { Cadmium } \\
\text { Chromium } \\
\text { Lead } \\
\text { Mercury } \\
\text { Selenium } \\
\text { Silver }\end{array}$ & $\begin{array}{r}71.0 \\
137 \\
81.0 \\
2210 \\
344000 \\
1550 \\
20.0 \\
4.0 \\
\end{array}$ & $\left|\begin{array}{l}\overline{\bar{z}} \\
\underline{B} \\
- \\
- \\
- \\
\overline{\bar{\alpha}} \\
\overline{\underline{D}}\end{array}\right|$ & N & $\begin{array}{l}\frac{\bar{P}}{P} \\
\frac{P}{P} \\
\frac{P}{\frac{P V}{P}} \\
\frac{P}{P} \\
\end{array}$ \\
\hline
\end{tabular}

Color Before: COLORTESS

Color After: COLORLESS

Comments:
Clarity Before: CLEAR

Clarity After: CLEAR
Texture:

Artifacts: NO

PORM I - IN 
Lab Name: TCT-ST. LUUIS

Contract: ERUTOSO2

Lab Code: TCT

Case No.: TUSO2 SAS NO.:

EG\&G Sample No.

jample Matrix: (so11/water/other) SOIL

Extract Matrix: (water) WATER

Lab Sample ID: 92006652

Extract vol: 5

$(m \perp)$

Lab File ID:

UH1403

Level: $\quad($ Low/med $)$ Low

* Molsture: not dec. dec.

Date Received: $10 / 02 / 92$

Column: (nar/wide/pack) WIDE

Date of 2HE: $10 / 07 / 92$

Date Analyzed: $10 / 19 / 92$

Dilution factor: 5

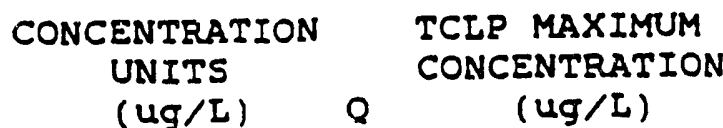

CAS NO.

COMPOUND

(ug/L)

$(\log / 2)$

\begin{tabular}{|c|c|c|c|}
\hline \multicolumn{3}{|c|}{$1 \longdiv { 1 }$} & 1 \\
\hline \multirow{3}{*}{\multicolumn{2}{|c|}{ 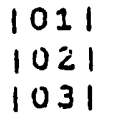 }} & $75-01-4$ & I viny 1 chloride \\
\hline & & $75-35-4$ & 1 1.1-U1chloroethene \\
\hline & & $67-66-3$ & Chlorotorm \\
\hline \multirow{2}{*}{\multicolumn{2}{|c|}{$\begin{array}{l}1041 \\
1051\end{array}$}} & $\begin{array}{l}107-06-2 \\
78-03-3\end{array}$ & $\left\{\begin{array}{l}1.2 \text {-Dichloroethane } \\
2 \text {-Butanone }\end{array}\right.$ \\
\hline & & $\begin{array}{l}78-93-3 \\
50-23-5\end{array}$ & $\begin{array}{l}\text { 2-Butanone } \\
\text { Carbon Tetrachloride }\end{array}$ \\
\hline \multirow{2}{*}{\multicolumn{2}{|c|}{$\begin{array}{l}1061 \\
1071\end{array}$}} & $\begin{array}{l}5 i-23-5 \\
79-01-6\end{array}$ & $\begin{array}{l}\text { Carbon Tetrachloride } \\
\text { Trichloroethene }\end{array}$ \\
\hline & & $\begin{array}{l}79-01-6 \\
71-43-2\end{array}$ & $\begin{array}{l}\text { Tricnloroetnene } \\
\text { Benzene }\end{array}$ \\
\hline \multicolumn{2}{|c|}{1081} & $71-43-2$ & $\begin{array}{l}\text { Benzene } \\
\text { Tetrach Loroethene }\end{array}$ \\
\hline \multicolumn{2}{|c|}{1091} & $127-18-4$ & Tetracndoroetnene \\
\hline \multicolumn{2}{|c|}{1101} & $1 \cup 8-30-7$ & Chlorodenzene \\
\hline $\begin{array}{l}1 \\
1\end{array}$ & 1 & & 1 \\
\hline 1 & 1 & & 1 \\
\hline 1 & 1 & & 1 \\
\hline 1 & 1 & & 1 \\
\hline 1 & 1 & & 1 \\
\hline 1 & 1 & & 1 \\
\hline 1 & 1 & & 1 \\
\hline 1 & 1 & & 1 \\
\hline 1 & 1 & & 1 \\
\hline 1 & 1 & & 1 \\
\hline 1 & 1 & & 1 \\
\hline 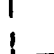 & 1 & & 1 \\
\hline
\end{tabular}




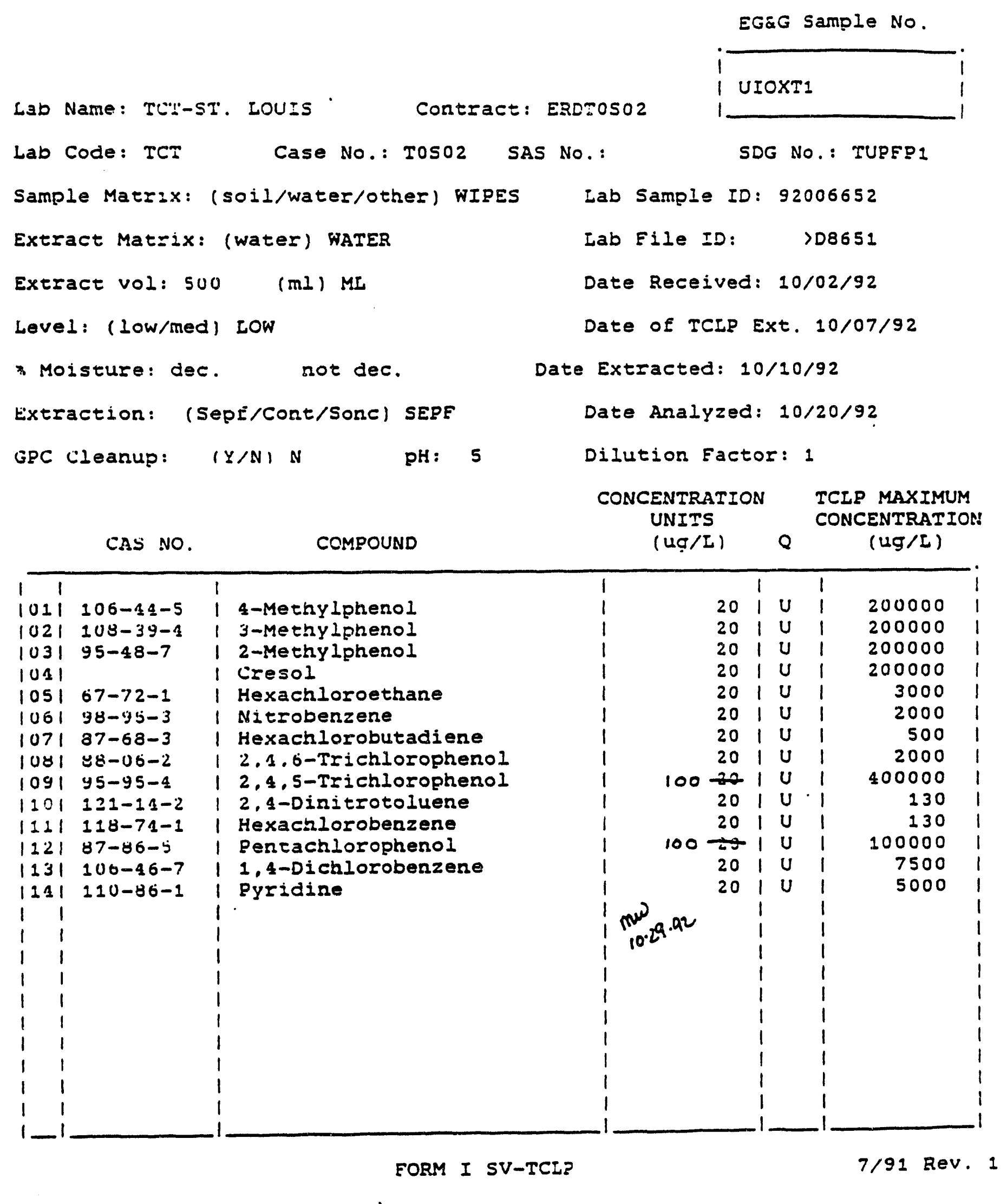




\section{ORGAHOCHLORIKE HERBICIDOE MULYSIS OATA SHEET TCLP}

EGag Sarcle Ho.

Lab Name: TCT, 5T, Laus Contrac::ERDTOSO2

U10 $\times 1 /$

Lao Coce: TCT Case No.: T0S0z SAS Mo.: NA SOO No.: TUPFPl

Samcie Matrix: isgii/water/oiner CTHER Lao samie 10: Q2005652

Ext-ac: Matrix: (water) wTER Las ilie It: NA

Exirac: vo:: $500 \cdot(m L ! M L$

Levei: (iow) Low

* Moisture: not des. $\nu$ des. $N A$

Extraction: (Hert) $\mathbb{H}=R B$

GPC Cleanup: $(\dot{Y} / \mathrm{M}) \perp \mathrm{PH}: 5$

Date-Reseives: $10-2-92$

Date of TCLP Extraction: $; 0-7-92$

Oate Extracted: 10-14-92

Date Analyzed: $10-26-92$

Dilution Factor: 1.0

\begin{tabular}{|c|c|c|c|c|}
\hline CAS NO. & COMPOUNO & $\begin{array}{c}\text { COACSHTRATION } \\
\text { UNITS } \\
\text { (Ug/L) }\end{array}$ & 0 & $\begin{array}{c}\text { TCD MAXIMUM } \\
\text { CONEENTRATION } \\
(\text { Ug/L) }\end{array}$ \\
\hline $\begin{array}{l}l i 94-: 5 \cdot i \\
2193-i 2 \cdot \vdots\end{array}$ & !'siivex & $\frac{0.500}{0.500}$ & $\frac{4}{4}$ & $: \begin{array}{r}10000 \\
1000\end{array}$ \\
\hline & & & & $T$ \\
\hline & & & & $T$ \\
\hline 1 & & & & 1 \\
\hline$\div$ & $\div$ & & & $\vdots$ \\
\hline$!$ & 1 & $\div$ & & $\frac{1}{1}$ \\
\hline$\therefore$ & & $!$ & & $T$ \\
\hline 1 & & & & $I$ \\
\hline$i$ & & & & $I$ \\
\hline 1 & & & & $I$ \\
\hline 1 & & & & \\
\hline$I$ & & & & \\
\hline 1 & & & & \\
\hline$T$ & & & & 1 \\
\hline$I$ & & & & $T$ \\
\hline$I$ & & & & \\
\hline 1 & & & & $I$ \\
\hline$T$ & & & & \\
\hline$I$ & & & & \\
\hline 1 & & & & \\
\hline 1 & & & & \\
\hline 1 & & & & \\
\hline 1 & & & & \\
\hline
\end{tabular}

FORA I OCHERB-TCLP

7/91 Rev. 
Lab Name: TCT-ST. LOUIS Contract: EROTOSO2 U10XT1

Lab Code: TCT Case No.: TOSO2 SAS No.: SOG NO.: TUPFPI Sample Matrix: (soil/water/other) Lab Lample ID: 9200652 Extract Matrix: (water) WATER

Extract vol: Doe (mL) ell Lab File ID: Level: (low) Date Received: NA Date of TCLP Extraction: 10.1 \&2: * Moisture: not dec. NA dec. NA Date Extracted: 10-13- Z Preparatory Extraction: (SepF/Cont) SEeE Date Analyzed: 10-23-92 GPC Cleanup: (Y/N) $N$ PH: $\Sigma$

Dilution Factor:

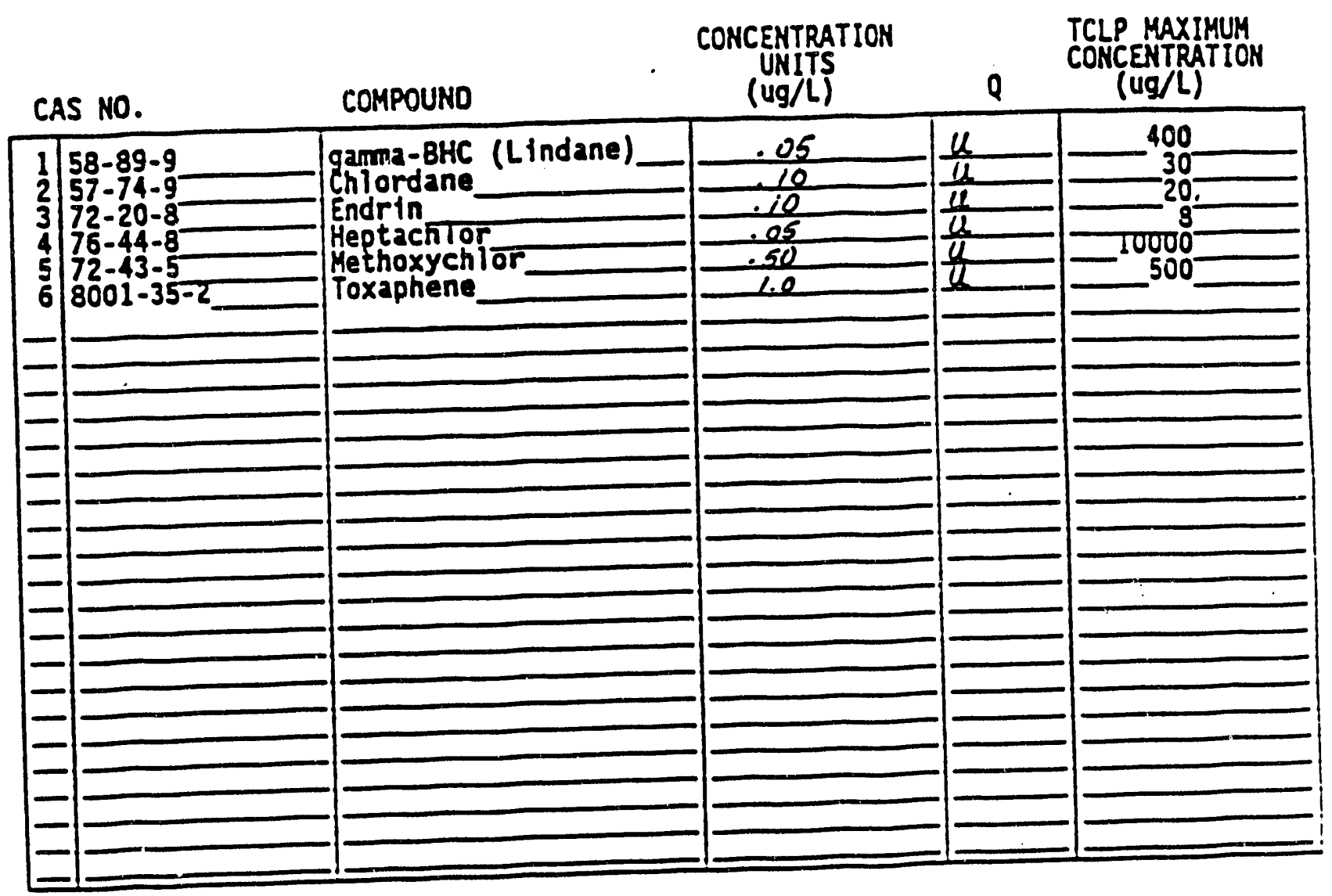

FORM I OCPEST-TCLP

7/91 Rey. 
INORGANIC ANALYSIS DAMA SEEET

Lab Name: TCI st. Louis Contract: ERDTOSO2

DIOXTI

Lab Code: TCT

Case NO.: TOSO2

SAS NO.:

SDG NO.: TUPET1

Matrix (soil/water): WATER

Lab Sample ID: 92006652

Level (low/med): IOW

Date Received: 10/02/92

\& Solids:

0.0

Concentration Jnits (ug/L or mg/kg dry weight): $\sigma G / L$

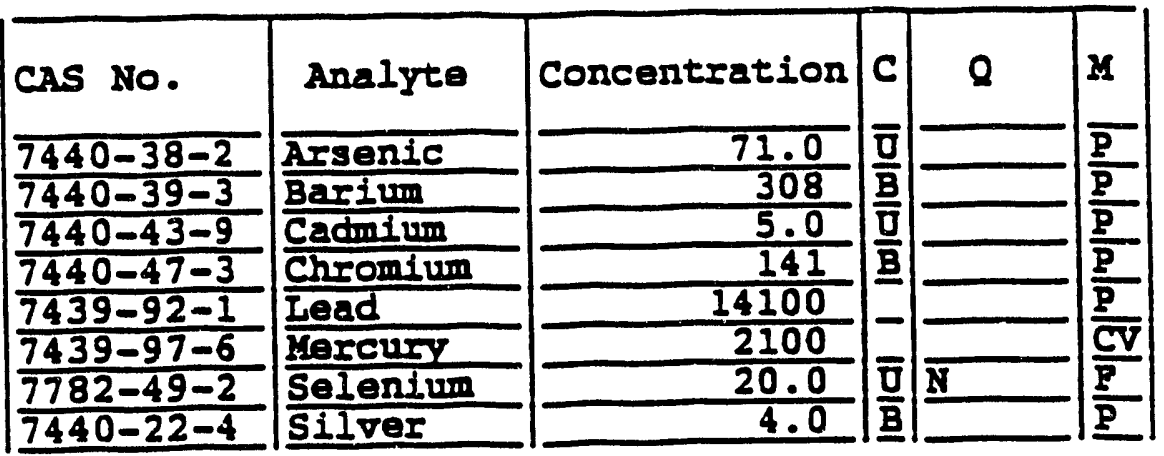

Color Before: COLORLESS

Color After: COLORTESS

Comments:
Clarity Before: CLEAR

Clarity After: CLEAR
Texture:

Artifacts: NO

BORM I - IN 
EGág Sample NC.

Lab Name: T:T-ST. IUJIS COntraEs: ERDTOSU2

Lab Vode: TCT Case No.: TOSO2 SAS No.:

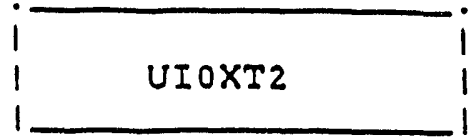

SDG NO.: TUPEF:

Sample Mati2x: (soil/water/other) soII

Extract Matrix: (water) WATER

Lab Sample ID: 92006654

Extract vol: $5 \quad(\mathrm{ml})$

Lab File ID: UH1406

Level: (low/med) LOW

Date Received: $10 / 02 / 92$

Molsture: not dec. dec.

Date of ZHE: $10 / 07 / 92$

Column: (nar/wide/pack) WIDE

Date Analyzed: $10 / 19 / 92$

Dilution factor: 5

CONCENTRATION TCLP MAXEMUM UNITS

CAS NO.

COMPOUND

(ug/L)

CONCENTRETION

$(u g / I)$

\begin{tabular}{|c|c|c|c|c|}
\hline \multicolumn{3}{|c|}{11} & \multicolumn{2}{|l|}{1} \\
\hline & & $75-01-4$ & 1 & Vinyl chloride \\
\hline 11) & & $75-35-4$ & 1 & 1.1-Dichloroethene \\
\hline 10 & & $67-66-3$ & 1 & Chlorotorm \\
\hline 10 & & $107-06-2$ & 1 & 1.2-ijichloroe chane \\
\hline 10 & & $78-93-3$ & 1 & 2-Butanone \\
\hline 10 & & $56-23-5$ & 1 & Carbon Tetrachloride \\
\hline 10 & & $79-01-6$ & 1 & Trichloroethene \\
\hline ia & & $71-43-2$ & 1 & Benzene \\
\hline 10 & & $127-18-4$ & 1 & Tetrachloroethene \\
\hline 11 & & $108-90-7$ & 1 & Chlorobenzene \\
\hline 1 & 1 & & 1 & \\
\hline 1 & 1 & & 1 & \\
\hline 1 & 1 & & 1 & \\
\hline 1 & 1 & & 1 & \\
\hline 1 & 1 & & 1 & \\
\hline$!$ & 1 & & 1 & \\
\hline 1 & 1 & & 1 & \\
\hline 1 & 1 & & 1 & \\
\hline 1 & 1 & & 1 & \\
\hline 1 & 1 & & 1 & \\
\hline 1 & 1 & & 1 & \\
\hline$!$ & 1 & & 1 & \\
\hline 1 & 1 & & 1 & \\
\hline
\end{tabular}

FORM I VOA-TCIP 


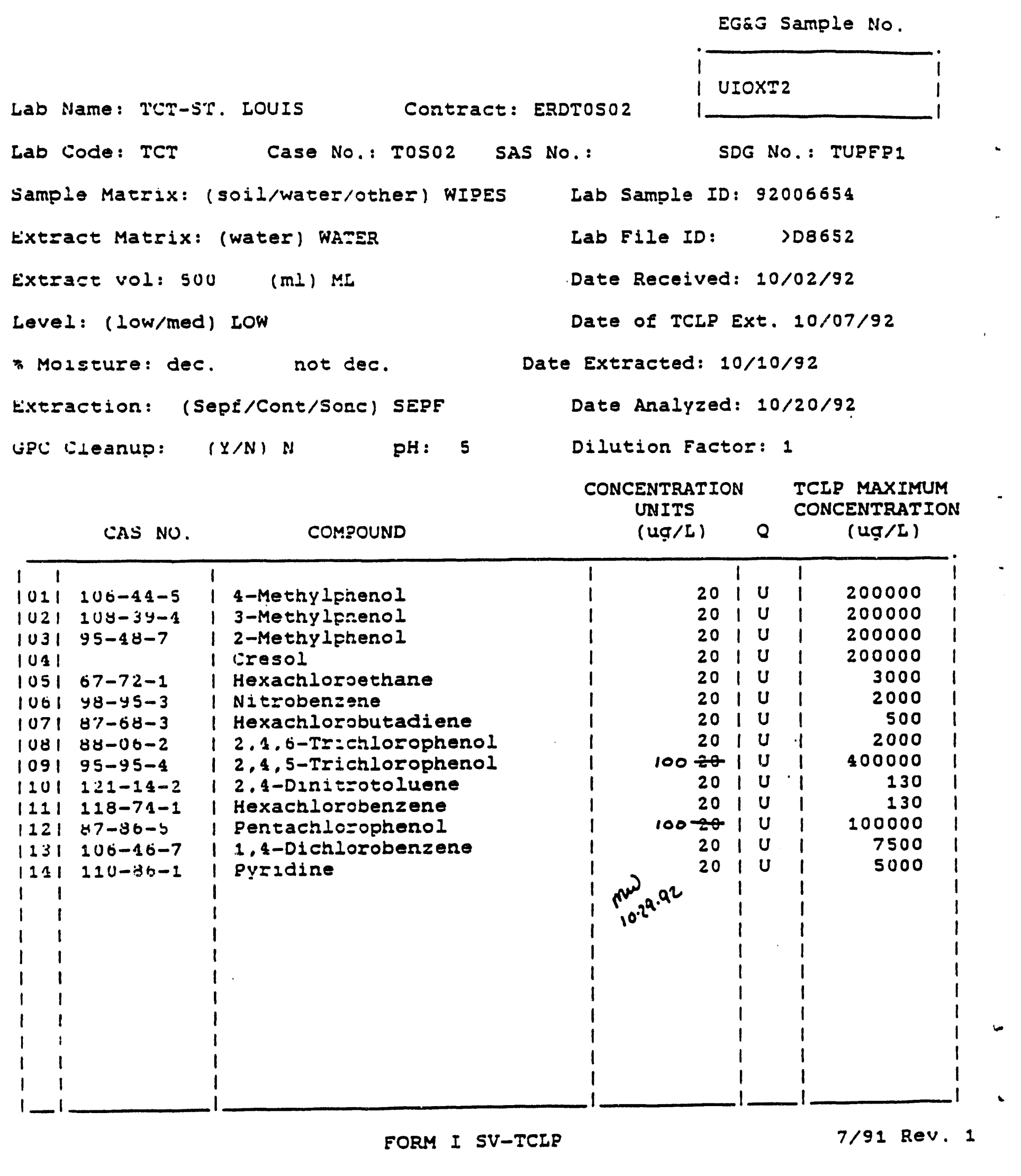


Eũas Sanole No.

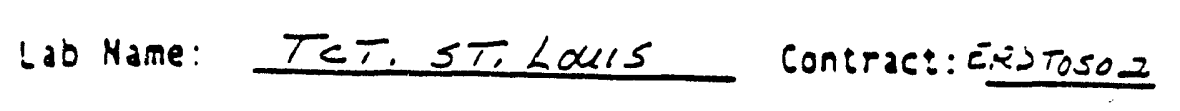

$410 \times 12$

Lao Cooe: TeT Case No.: TOSO2 SAS No.: NA SOC No.: TUPfPl

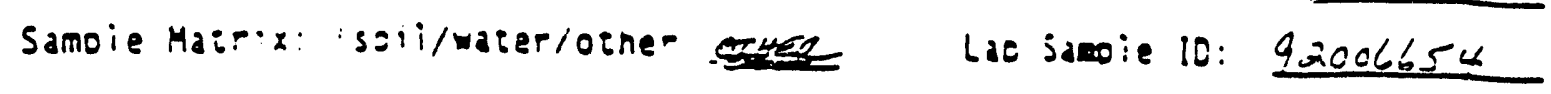

Extrac: Matr:x: iwateri wroes

Exirac: vo: : 500 (nL: ML

Levei: (iow) Low

* Moisture: not des. LA des. NA

Extraction: (Hert) HeRB

Las :ite IE: NA

GPC Cleanup: $(\dot{Y} / N) \perp$ PH: 5

Date-Reseives: $10-2-92$

Dase of TCLP Extraction: $10-7-92$

Daie Extracted: $10-14-92$

Date Analyzed: $10-26-92$

Dilution Factor: 1.0

\begin{tabular}{|c|c|c|c|c|}
\hline CAS NO. & SOMPOUNO & $\begin{array}{c}\text { CONCENTRATION } \\
\text { UNITS } \\
\text { (UG/L) }\end{array}$ & 0 & $\begin{array}{l}\text { TC.D MAXIMUM } \\
\text { CONEENTRATION } \\
(\text { Ug/L) }\end{array}$ \\
\hline $\begin{array}{l}?: 34-75-7 \\
2195-i 2-i \\
\end{array}$ & $\begin{array}{l}\text { i2.4-D } \\
\text { !siivex }\end{array}$ & $\frac{1.10}{0.500}$ & 4 & $\begin{array}{r}10000 \\
1000\end{array}$ \\
\hline & & & & $T$ \\
\hline & & & & $T$ \\
\hline 1 & & & & 1 \\
\hline & $i$ & & & \\
\hline 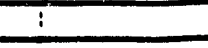 & 1 & $:$ & & 1 \\
\hline$\dot{ }$ & 1 & $i$ & & $I$ \\
\hline 1 & 1 & & & \\
\hline$i$ & 1 & & & $I$ \\
\hline 1 & & & & \\
\hline$T$ & & & & \\
\hline & & & & \\
\hline & & & & \\
\hline & & & & \\
\hline 1 & & & & \\
\hline & & & & \\
\hline$T$ & & & & \\
\hline & & & & \\
\hline & & & & \\
\hline$\frac{1}{1}$ & & & & \\
\hline$T$ & f & & & \\
\hline
\end{tabular}




\section{ORGANOCHLORINE PESTIC:}

EGäG Sample Mo.

Lab Name: TCT-ST. LOUTS Contract: EROTOSaO

$010 \times 12$

Lab Code: TCT Case No.: Tosoz SAS No.:

SOG NO.: TUPEPI

Sample Matrix: (soil/water/other) Lree Lab Sample ID: azoob65t

Extract Matrix: (water) WATER

Lab Flle ID:

Extract vol: $\infty$

Dace Recaived: 10-2-92

Leve 1: (low)

Date of TCLP Extraction: 10-7-92

: Moisture: not dec. NA dec. NA Date Extracted: $10-13-92$

Preparatory Extraction: (SepF/Cont) SEE Date Analyzed: 10-23-92

GPC Cleanup: $(Y / N) N$ PH: $\underline{S}$

Dilution Factor: 1

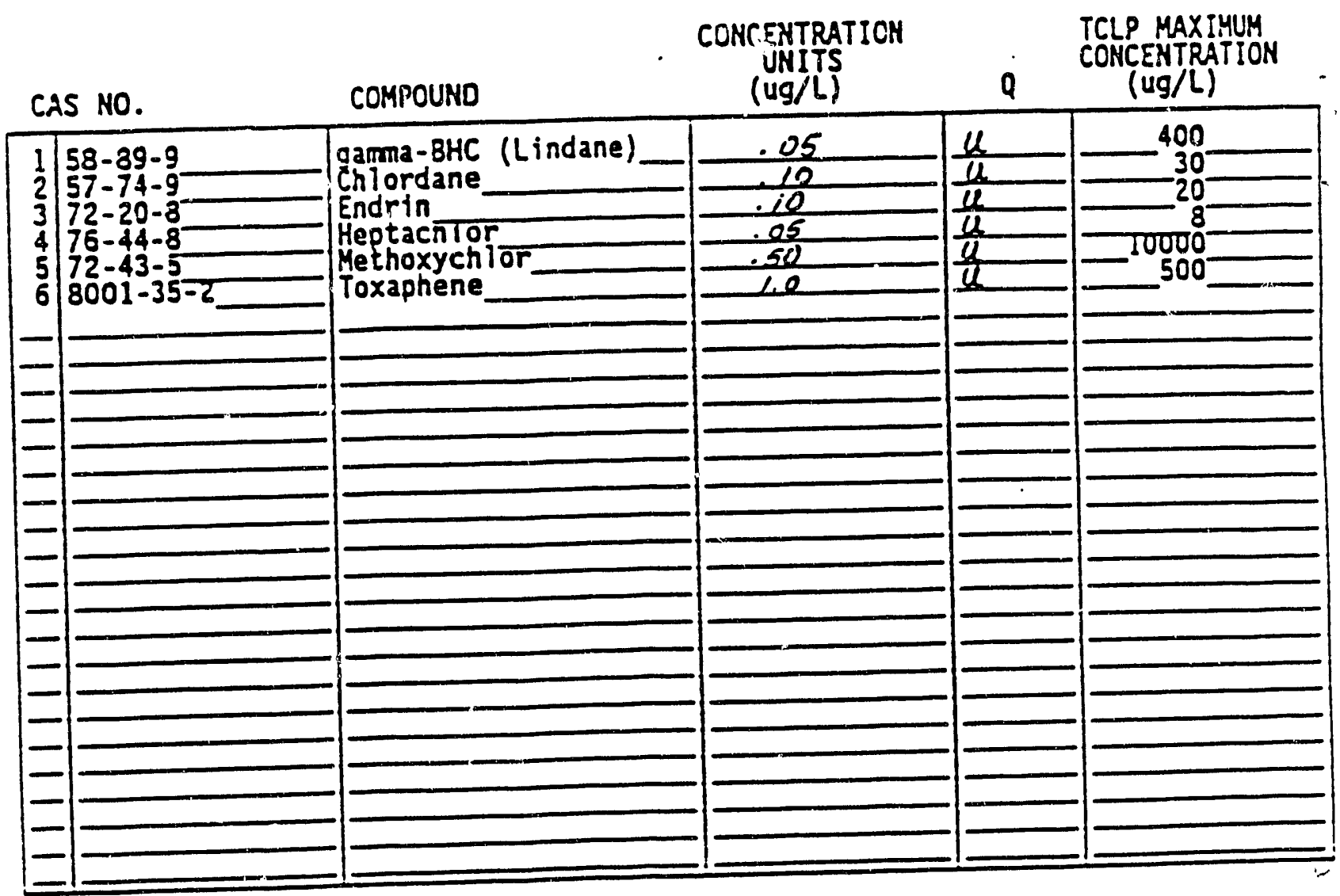

FORM I OCPEST-TCLP

7/91 Rey. 
INORGRYIC ANALYSIS DATA SEEET

Lab Name: TCI St. Louis Contract: ERDTOSO2

DIOXT2

Lab Code: TCT

Case No.: TOSO2 SAS NO.:

SDG NO.: TUPFT1

Matrix (soil/water): WATER

Lab Sample ID: 92006654

Level (low/med): IOW

Date Received: 10/02/92

\& Solids:

0.0

Concentration Units (ug/I or mg/kg dry weight): $U G / L$

\begin{tabular}{|c|c|c|c|c|c|}
\hline CAS HO. & Analyte & Concentration & c & $\mathbf{Q}$ & $\mathbf{X}$ \\
\hline$\frac{7440-38-2}{\frac{7440-39-3}{7440-43-9}} \frac{74 \frac{740-47-3}{7439-92-1}}{\frac{7439-97-6}{7782-49-2}} \frac{1}{7440-22-4}$ & $\begin{array}{l}\text { Arsenic } \\
\text { Barium } \\
\text { Cadmium } \\
\text { Chromium } \\
\text { Lead } \\
\text { Mercury } \\
\text { Selenium } \\
\text { Silver }\end{array}$ & $\begin{array}{c}\frac{71.0}{338} \\
\frac{5.0}{140} \\
\frac{3120}{2740} \\
\frac{20.0}{4.0} \\
\frac{4120}{4}\end{array}$ & 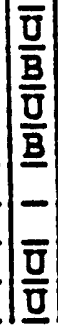 & 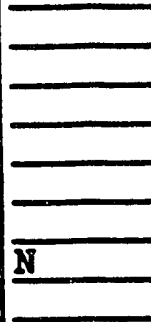 & $\mid \begin{array}{l}\frac{\bar{P}}{P} \\
\frac{P}{P} \\
\frac{P}{\frac{P}{P}} \\
\frac{P}{P}\end{array}$ \\
\hline
\end{tabular}

Color Before: COLORLESS

Clarity Before: CIEAR

Texture:

Color After: COLORTESS

Clarity After: CTEAR

Artifacts: NO

Comments :

FORY I - IN 


\section{TCT - St. Louis}

Consulung Engineers. Scsenuses and Anavitical Sernces

November 25, 1992

1908 Innerioelt Business Center Drive St. Louis. .íissouri 631145700

Phone (314) $426-0890$

9259-000013

Fax (314) $426-4212$

Ms. Donna Kirchner

Field Data Coordinator

ERP Administrative Record

and Document Control

EG\&G Idaho, Inc.

P.O. Box 1625

Idaho Falls, ID 83415-3904

Re: Data Package for Task Order 15 Under Subcontract C92-170021

Dear Ms. Kirchner:

Enclosed is a data report for the analysis of samples received by TCT-St. Louis under subcontract No. C92-170021/Task Order 15, (TOS No. ERD-TOS-02, MOD 2). This report contains analytical sample data for samples collected from treatability studies being conducted at the Test Reactor Area (TRA).. The samples were analyzed specifically for TCLP Mercury.

The samples were received by TCT-St. Louis on October 23,1992 with a stated turn-around tire of the final repor in 35 days from receipt of the last sample in the SDG. The due date for the final report is November 27, 1992. The preliminary report of the quick turn around water samples was delivered on October 27, 1992 to Isabel Anderson.

The EG\&G sire codes, corresponding File I.D.'s, TCT.St. Louis laboratory sample numbers for each sampie delivery group are shown in the following tables.

\section{SDG UTWF1M - TCLP MERCURY}

EG\&G STTE ID $\quad$ FILE ID

TCT LAB NO.

UTWF1M

UTWF2M

92007340

92007341

DATE COLLECTED

$10 / 22 / 92$

$10 / 22 / 92$

For reporting purposes, the contract number is ERDTOS02 and case number TOS02. All samples were analyzed and reported per the requirements of C92-170021 TASK ORDER NO. 15, ERD-TOS-02 MOD 2

The yellow original chain-of-custodies were mailed to Donna Kirchner on November 10, 1992.

\section{TCLP METALS - SDG UTWF1M}

The samples were analyzed within the required holding times. A CLP equivalent data package has been prepared. A matrix spike and duplicate analysis were performed on 
sample UTWF1M.

This work will be invoiced under purchase order number C92-170021 and TCT-St. Louis project number - 9259-000012.

If you have any questions concerning this data report, please call me at (314) 426-0880.

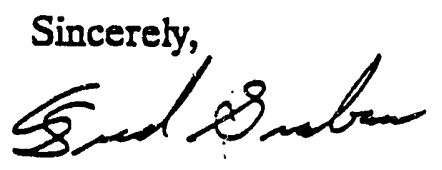

Fred Grabau

Project Manager 
1

INCRGANIC ANAIYSIS DATA SHEET

Lab Name: TCT St. Louis

Contract: ERDTOSO2

Iab Code: TCT

Case No.: TOSO2
SAMPIE NO.

EXTBNR

MatIix (soil/water): WATER

Lab Sample ID: OPA7288

Level (low/med): LOW

Date Received: $10+23+2$

\& Solids:

0.0

$\min _{102+2+2.2 .}$

Concentration Dnits (ug/I or $\mathrm{mg} / \mathrm{kg} d r y$ weight): $\mathrm{dG} / \mathrm{L}$

\begin{tabular}{|c|c|c|c|c|c|}
\hline CAS NO. & Analyte & Concentration & c & $Q$ & $y$ \\
\hline $7429-90-5$ & Aluminum & & - & & - \\
\hline $7440-36-0$ & Antimony & & - & & - \\
\hline $7440-38-2$ & Arsenic & & & & \\
\hline $7440-39-3$ & Barium & & - & & \\
\hline $7440-41-7$ & Beryllium & & $=$ & & $1-$ \\
\hline $7440-43-9$ & Cadmium & & - & & $1 \rightarrow$ \\
\hline $7440-70-2$ & Calcium & & & & \\
\hline $7440-47-3$ & Chromium & & & & \\
\hline $7440-48-4$ & Cobalt & & -1 & & $1-$ \\
\hline $7440-50-8$ & Cooper & & -1 & & \\
\hline $7439-89-6$ & Iron & & -1 & & \\
\hline $7439-92-1$ & Lead & & -1 & & 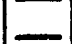 \\
\hline $7439-95-4$ & Magnesium & & - & & - \\
\hline $7439-96-5$ & Manganese & & & & \\
\hline $7439-97-6$ & Mercury & 0.10 & $\overline{\mathbf{v}}$ & & $\overline{C V}$ \\
\hline $7440-02-0$ & Nickel & & -1 & & - \\
\hline $7440-09-7$ & Potassium & & - & & \\
\hline $7782-49-2$ & Selenium & & - & & \\
\hline $7440-22-4$ & Silver & & - & & - \\
\hline $7440-23-5$ & Sodium & & - & & - \\
\hline $7440-28-0$ & Thallium & & - & & \\
\hline $7440-62-2$ & Vanadium & & -1 & & \\
\hline $7440-66-6$ & inc & & -1 & & - \\
\hline & Cranide & & & & \\
\hline
\end{tabular}

Color Before: COLORLESS

Color After: COLORLESS

Comments:
Clarity Before: CLEAR

Clarity After: ' CLRAR
Texture:

Artifacts :

FORY I - IN

E-50 
SAMPLE NO.

1

INORGANIC ANALYSIS DATA SHEEM

Iab Name: TCT St. Louis

Contract: EzDTOSO2

OTWE 1M

SAS NO.:

SDG NO.: UIHF 1Y

Lab Code: TCT

Case NO.: TOSO2

Matrix (soil/water): WATER

Lab Sample ID: 92007340

Dace Received: 10/23/92

Level (Low/med): IOW

\& Solids :

0.0

Concentration Units (ug/L or $\mathrm{mg} / \mathrm{kg} d r y$ weight) : $\mathrm{dG} / \mathrm{I}$

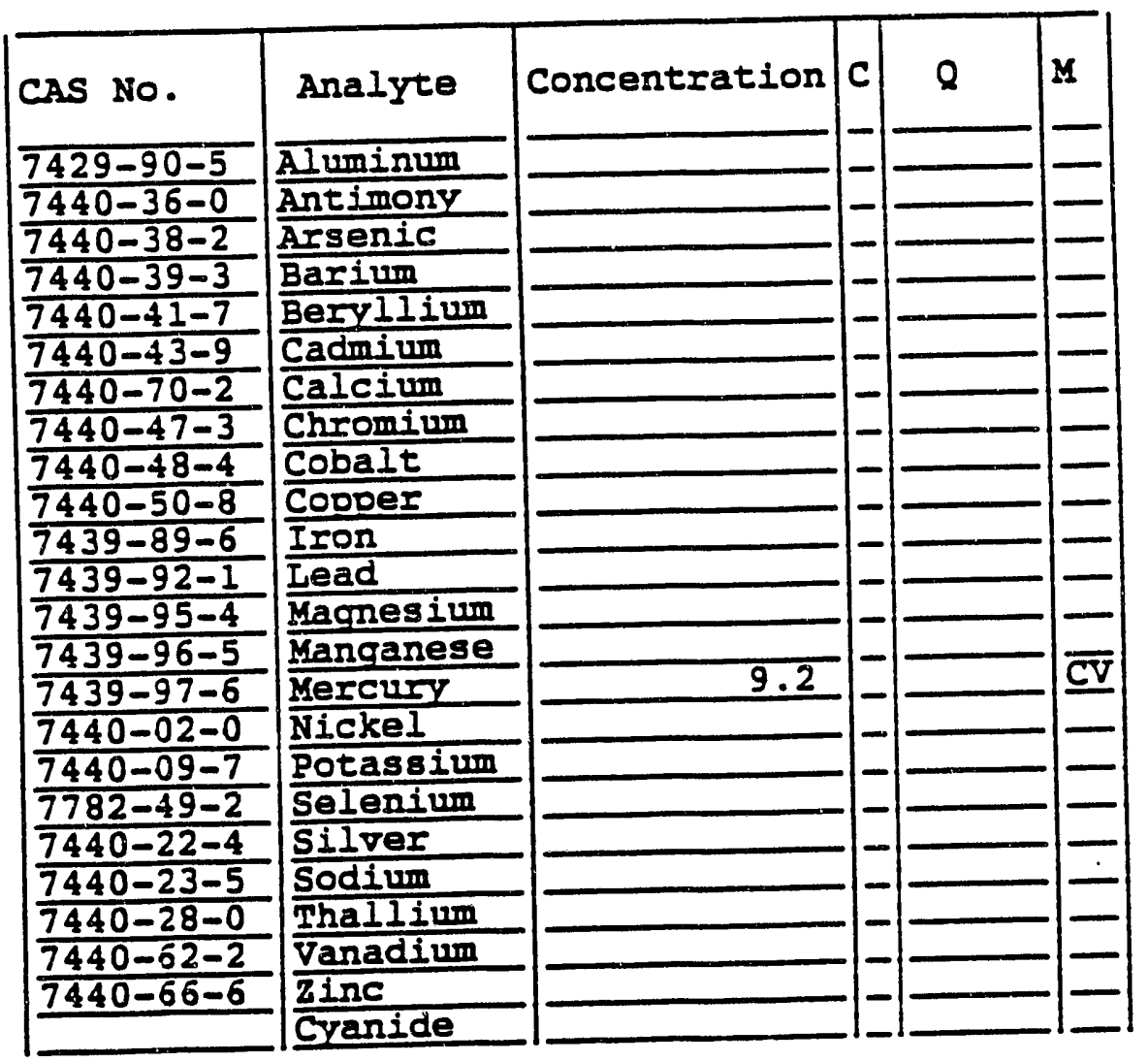

Color Before: COLORTESS

Color After: COLORIESS

Comments :
Clarity Before: CLEAR

Clarity After: ' CLRAR
Texture:

Artifacts:

FORM I - IN 
1

INORGANIC ANALTSIS DATA SHEET

Lab Name: ICI St. Iouis

Contract: ERDTOSO2

Iab Code: mCT

Case No.: TOSO2

Matrix (soil/water): WATER

Level (lcw/med): INW

\& Solids :

0.0

Concentration Units (ug/L or $\mathrm{mg} / \mathrm{kg} d r y$ weight): $U G / L$

\begin{tabular}{|c|c|c|c|c|c|}
\hline CAS NO. & Analyta & Concentration & c & $Q$ & $\mathbf{M}$ \\
\hline $7429-90-5$ & Aluminum & & -1. & & \\
\hline $7440-36-0$ & Antimony & & $=$ & & - \\
\hline $7440-38-2$ & Arsenic & & & & \\
\hline $7440-39-3$ & Barium & & -1 & & - \\
\hline $7440-41-7$ & Beryl1ium & & -1 & & - \\
\hline $7440-43-9$ & Cadmium & & & & \\
\hline $7440-70-2$ & Calcium & & -1 & & - \\
\hline $7440-47-3$ & Chromium & & -1 & & \\
\hline $7440-48-4$ & Cobalt & & - & & \\
\hline $7440-50-8$ & Copper & & - & & \\
\hline $7439-89-6$ & IIOn & & - & & - \\
\hline $7439-92-1$ & Lead & & & & \\
\hline $7439-95-4$ & Magnesium & & & & \\
\hline $7439-96-5$ & Manganese & & -1 & & \\
\hline $7439-97-6$ & Mercusy & 16.8 & -1 & & $\overline{\mathrm{CV}}$ \\
\hline $7440-02-0$ & Nickel & & -1 & & \\
\hline $7440-09-7$ & Potassium & & - & & - \\
\hline $7782-49-2$ & Selenium & & -1 & & \\
\hline $7440-22-4$ & silver & & -1 & & \\
\hline $7440-23-5$ & Sodium & & - & & - \\
\hline $0-28-0$ & Thallium & & $=$ & & \\
\hline $0-62-2$ & Vanadium & & -1 & & \\
\hline $7440-66-6$ & Zinc & & - & & \\
\hline & Cranide & & & & \\
\hline
\end{tabular}

Color Before: COLORIESS

Color After: COLORIESS

Comments:
SAMPLE NO.

UTWE2M

SDG NO.: UTWF IM

Iab Sample ID: 9200734 I

Date Received: 10/23/92 

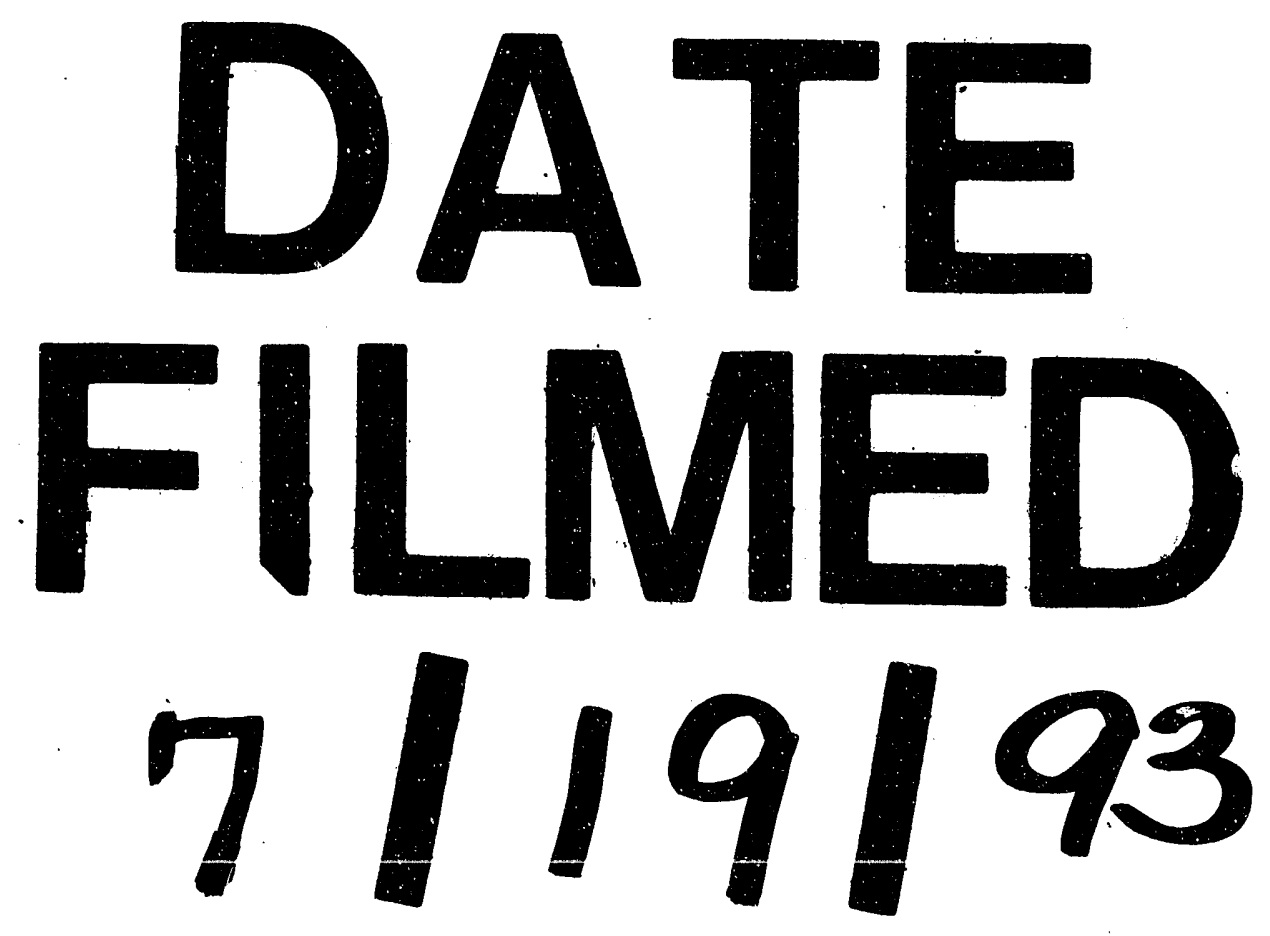


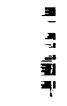

